\title{
Bedrijfskenmerken en ziekteverzuim in de jaren zestig en tachtig : een vergelijkende studie
}

Citation for published version (APA):

Smulders, P. G. W. (1984). Bedrijfskenmerken en ziekteverzuim in de jaren zestig en tachtig : een vergelijkende studie. [Doctoral Thesis, Maastricht University]. Instituut voor Praeventieve Gezondheidszorg TNO. https://doi.org/10.26481/dis.19840907ps

Document status and date:

Published: 01/01/1984

DOI:

10.26481/dis.19840907ps

Document Version:

Publisher's PDF, also known as Version of record

\section{Please check the document version of this publication:}

- A submitted manuscript is the version of the article upon submission and before peer-review. There can be important differences between the submitted version and the official published version of record. People interested in the research are advised to contact the author for the final version of the publication, or visit the DOI to the publisher's website.

- The final author version and the galley proof are versions of the publication after peer review.

- The final published version features the final layout of the paper including the volume, issue and page numbers.

Link to publication

\footnotetext{
General rights rights.

- You may freely distribute the URL identifying the publication in the public portal. please follow below link for the End User Agreement:

www.umlib.nl/taverne-license

Take down policy

If you believe that this document breaches copyright please contact us at:

repository@maastrichtuniversity.nl

providing details and we will investigate your claim.
}

Copyright and moral rights for the publications made accessible in the public portal are retained by the authors and/or other copyright owners and it is a condition of accessing publications that users recognise and abide by the legal requirements associated with these

- Users may download and print one copy of any publication from the public portal for the purpose of private study or research.

- You may not further distribute the material or use it for any profit-making activity or commercial gain

If the publication is distributed under the terms of Article $25 \mathrm{fa}$ of the Dutch Copyright Act, indicated by the "Taverne" license above, 
BEDR I JF SKENMERKEN EN ZIEKTEVERZUIM IN DE JAREN ZESTIG EN TACHTIG

$$
\text { een vergelijkende studie }
$$


Nederlands Instituut voor

Praeventieve Gezondheidszorg TNO

Wassenarseweg 56 - Leiden

Postadres:

Postbus 124

2300 AC Leiden

Telefoon: $071-170441$

CIP-GEGEVENS KONINKLIJKE BIBL IOTHEEK, DEN HAAG

Smulders, P.G.W.

Bedrijfskenmerken en ziekteverzuim in de jaren zestig en tachtig: een vergelijkende studie / P.G.W. Smulders. - (Den Harg : TNO) Proefschrift Mastricht. - Met lit.opg.

ISBN 90-6743-036-6

SISO 367.1 UDC 658.3

Trefw.: ziekteverzuim / bedrijfskenmerken

- 1984 Nederlands Instituut voor Praeventieve Gezondheidszorg TNO Publikatienummer 84014

Voor de rechten en verplichtingen van de opdrachtgever met betrekking tot de inhoud van dit rapport wordt verwezen naar de Algemene Voorwaarden van TNO.

Niets uit deze uitgave mag worden verveelvoudigd, openbaar gemaakt en/of verspreid door middel van druk, fotocopie, microfilm of op welke wijze ook zonder voorafgaande schriftelijke toestemming van het NIPG-TNO. 
BEDRIJF SKENMERKEN EN ZIEKTEVERZUIM IN DE JAREN ZESTIG EN TACHTIG een vergelijkende studie

\section{PROEF SCHR IF T}

ter verkrijging van de graad van doctor in de Sociale Wetenschappen aan de Rijksuniversiteit Limburg te Maastricht op gezag van de Rector Magnificus Prof.Dr H.C. Hemker, volgens besluit van het College van Dekanen in het openbaar te verdedigen op vrijdeg 7 september

1984, des namiddags om vier uur precies, in de aula van de universiteit

door

$$
\begin{gathered}
\text { Peter Gerard Wim } 5 \text { mulders, } \\
\text { geboren te Utrecht }
\end{gathered}
$$


Promotor: Prof.Dr H. Philipsen

Referenten: Prof.Or Tj. de Boorder

Prof.Dr C.J. Lammers 
DANKWOORD

1. INLEIDING

1.1 De maatschappelijke relevantie van de studie

1.2 Enige hoofdkenmerken van de studie en de probleemstelling

1.3 De opbouw van deze publikatie

2. DE HISTORIE VAN DE THEORIEVORMING DVER ZIEKTEVERZUIM

2.1 Struktuur en doel van dit hoofdstuk

2.2 Niet-specifiek op verzuim gerichte (organisatie-)hypothesen

2.3 Niet-specifiek op verzuim gerichte (organisatie-) theorieën

2.4 Specifiek op verzuim gerichte hypothesen 24

2.5 Specifiek op verzuim gerichte theorieën 28

2.6 Samenvatting van hoofdstuk $2 \quad 41$

3. DE ONDERZOEKSOPZET 44

3.1 Replikatie-onderzoek 44

3.2 De onderzochte bedrijven in 1964/65 en 1980/81 45

3.3 De wijze van materiaalverzamelen 53

3.4 De konstruktie van de variabelen en de bepaling van hun gebruikswaarde

3.5 Het analyseplan en de analysetechnieken

4. DE DRGANISATIE ALS ANALYSE-EENHEID 60

4.1 Verzuimonderzoek op verschillende analysenivo's 60

4.2 Voor- en nadelen van verschillende analysenivo's 61

4.3 Andere problemen van organisationele analyse 66

4.4 Konklusies 69

5. VARIABELEN EN HYPOTHESEN 71

5.1 Het hypothetisch schema met de 32 verklarende variabelen

5.2 Beschrijving van de negentien verklarende variabelen uit de replikatie-analyse

5.3 Vergelijking van beide onderzoeken op de methodische aspekten: het replikatiekarakter

5.4 Beschrijuing van de dertien toegevoegde verklarende variabelen voor de vervolganalyse

5.5 De drie verzuimmaten 
6. DE RESULTATEN VAN DE REPLIKATIE-ANALYSE

6.1 De struktuur van dit hoofdstuk

6.2 De onderlinge samenhang van de negentien verklarende variabelen

6.3 De relaties van de negentien verklarende variabelen met het verzuim

6.4 Bespreking van de gevonden verschillen

6.5 Toetsing van de hypothesen

6.6 De validiteit van de verklarende variabelen

6.7 Samenvatting van hoofdstuk 6

7. DE RESULTATEN VAN DE VERVOLGANALYSE

7.1 De acht geëlimineerde en de dertien toegevoegde variabelen

7.2 De onderlinge samenhang van de 24 verklarende variabelen

7.3 Organisatie-sociologische bespreking van de zeven gevonden faktoren

7.4 De relaties van de 24 verklarende variabelen met het verzuin

7.5 Toetsing van de hypothesen

7.6 Integratie van de resultaten

7.7 Analyses van enige kausale modellen met behulp van de LISREL-techniek

7.8 Samenvatting van hoofdstuk 7

8. SLOTBESCHOIJWING

B.1 Inleiding

8.2 De voornaamste resultaten en hun praktische implikaties voor de beperking van verzuim

8.3 De gevonden resultaten in het licht van de verzuimtheorie

8.4 De ontwikkelingen van 1964/65 tot 1980/81

8.5 Enige verdere beleidsrelevante resultaten uit de faktoranalyse

SUMMARY

BIJLAGEN 
Een proefschrift, wordt tegenwoordig vaak gezegd, is zelden meer een zaak van een enkeling. Hoewel men dat tijdens het schrijven ervan lang niet altijd zo ervart, is het inderdaad een juiste konstatering.

Daarom wil ik allereerst de direktie van het Nederlands Instituut voor Praeventieve Gezondheidszorg TNO dank zeggen voor de tijd die zij mij voor dit projekt beschikbaar heeft willen stellen. Dit te meer, omdat we in een tijd leven, waarin opdrachtonderzoek om ekonomische redenen vaak voorrang moet hebben boven zogenaamd vrij speurwerk.

Voorts ben ik de promotor en referenten erkentelijk voor de door hen geïnvesteerde tijd en energie. Professor $D r H$. Philipsen heeft met zijn kommentaar op eerdere versies van de studie een kwaliteitsbevorderende invloed uitgeoefend. Het was $\mathrm{mij}$ ook een genoegen om voor deze dissertatie zo intensief met zijn eigen studie uit 1969 om te gaan. Professor Dr Tj. de Boorder heeft mij gewezen op redaktionele en bedrijfsgeneeskundige onvolkomenheden. Tenslotte bleken de suggesties van professor Dr C.J. Lammers, wiens student ik in de zestiger jaren was, een belangrijke stimulans bij de uitwerking van de organisatie-sociologische gedeelten.

Binnen het NIPG/TNO ben ik vooral dank verschuldigd aen mijn kollega's P. van Leeuwen en Drs D. Draaisma voor hun inbreng tijdens de opzet van het anderzoek en de tekstuele vormgeving van het proefschrift. D. Draalisma vervulde tevens een rol in de materiaalverzameling. In de eindtekst is verder kommentaar verwerkt van Dr A. Dijkstre, H. Hoolboom, arts, Drs M. Kastelein en Drs W.N. van Nooten.

Een belangrijke bijdrage aan de totstandkoming van dit boek is tevens geleverd door de volgende NIPG-medewerkers: R.M. Frese, ing. (dataverwerking), J.C.G. de Lange (literatuurvoorzilening), A.A.M. Paardekooper (concepttekstverwerking), H.G.S. Nooy van der Kolff (uiteindelijke tekstverwerking), N.H. de Kleijn (tekenwerk, lay-out, produktieregie), J.S. Sikkeme-de Graaff (tekstkorrektie), F.R. Voerman (omslagontwerp), P.H. de Blocq van Scheltinga (fotografie), J.N. van Kampenhout, J. van der Plas en J.J. van der Zwan (offsetdruk). Hun zorguldigheid en inzet heb ik zeer gewaar deerd. 
Tenslatte is het op zijn plaats de bedrijfsleiders en persaneelschef 8 van alle 85 bij het onderzoek betrokken bedrijuen te bedanken voor de informatie die zij hebben willen verschaffen. Zonder hun medewerking zou dit boek nooit verschenen zijn. 


\subsection{De matschappelijke relevantie van de studie}

Diskussies in de pers, beraadslagingen in het parlement, rapporten van Ministeries, Planbureaus en het Centraal Bureau voor de Statistiek laten zien hoe belangrijk de sociale verzekeringsuitkeringen zijn voor de financiële positie van ons land, vooral nu de betaalbaarheid ervan problematisch is geworden door de ekonomische teruggang.

Enige cijfers (in guldens) uit 1982 maken duidelijk welke plaats het ziekteverzuim in dit alles inneemt (CBS, 1983).

netto nationaal inkomen (marktprijzen) totale uitkeringen Sociale Verzekeringen idem in het kader van de Ziektewet idem in het kader van de WAO

$$
\begin{aligned}
& 328,5 \text { miljard }(=100 \%) \\
& 80,9 \text { miljard }(=24,6 \%) \\
& 6,5 \text { miljard }(=2,0 \%) \\
& 16,0 \text { miljard }(=4,9 \%)
\end{aligned}
$$

In 1982 werd dus ongeveer 6,5 miljard gulden aan uitkeringen verstrekt in het kader van de Zilektewet, hetgeen neerkomt op 2 procent van het netto nationaal inkomen. Hier kan nog aan toegevoegd worden dat deze uitkeringen betaald worden uit de premiegelden, die voor ongeveer 80 procent worden opgebracht door de werkgevers en voor ongeveer 20 procent door de werknemers (CBS, 1983).

In tegenstelling tot de meeste andere sociale verzekeringen, zoals de WAO, WW, AOW, etcetera, neemt de invioed van de Ziektewet op de sociale zekerheidsuitkeringen sinds enige jaren af. Dit vindt uiteraard zijn aorzaak in de daling van het ziekteverzuim in ons land, zoals figuur $1.1(p, 2)$ laat zien.

Uit de figuur valt op te maken dat de verzuimpercentages van 1959 tot 1979 ongeveer verdubbelden. Door de ekonomische problemen in ons land daalden de percentages na 1979 scherp. In 1983 bereikten ze circa 7,2 procent bij de mannen en 9,4 procent bij de vrouwen. Voorgaande gegevens laten ook zien dat zo'n 8 procent in het verzuim in 1982 (mannen en vrouwen te zamen) gepaard ging met bijna $6,5 \mathrm{miljard}$ gulden aan Zlektewetuitkeringen. Een daling in het verzuimpercentage van één procent kan dus een besparing van globaal 800 miljoen gulden opleveren in de nationale sociale zekerheid. Hier kan men nog bij vermelden dat verzuim in de bedrijuen, behalve met uitkeringen, ook met indirekte kosten gepaard gaat, bijvoorbeeld ten gevolge van verstoringen in de organisatie, lan- 


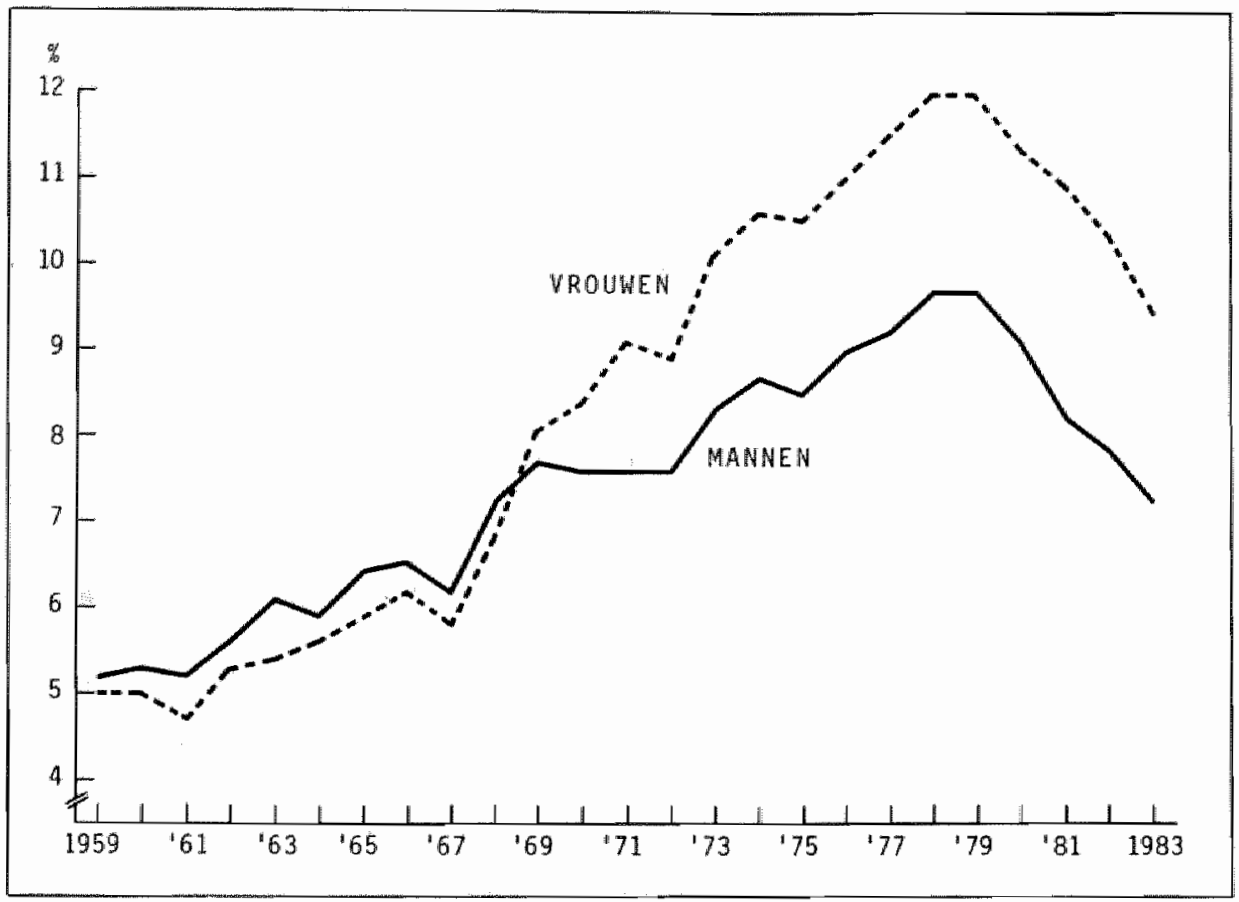

Bron: NIPG/TNO, Ziekteverzuimstetistiek

gere levertijden, stagnering in de goederenstroom, etcetera. Dit alles maakt de financiële effekten van het ziekteverzuim op zowel nationaal als bedrijfsnivo duidelijk. Onderzoek naar en inzicht in de oorzaken van verzuim is tevens van belang omdat de werkgevers en werknemers veelvuldig van mening verschillen als het gaat om het te volgen beleid. De eerste groepering heeft de neiging de onwilligheid en ongeinteresseerdheid van de werknemers te benadrukken, terwijl de laatste groepering oorzaken meestal legt bij de houding van direkties, het gebrek aan medezeggenschap en de onaantrekkelijke bedrijfsomstandigheden. Een konkreet voorbeeld van een onderzoeks- en veranderingsproces bij een groot metaalbedrijf, warbij de visies van de verschillende bedrijfsgroeperingen een belangrijke rol speelden, is te vinden in Smulders (1982). Op landelijk nivo ziet men de botsende visies op oorzaken en maatregelen regelmatig terug in rapporten en brochures van werkgevers- en werknemersorganisaties. 
Inzicht in het relatieve belang van de oorzaken van het verzuim kan dus een belangrijke bijdrage leveren aan het formuleren van beleidsmatregelen op dit terrein.

\subsection{Enige hoofdkenmerken van de studie en de pro- bleemstelling}

Het inzicht in de oorzaken van het ziekteverzuim wordt vanuit diverse wetenschappelijke disciplines op eigen wijze geleverd. De sociale geneeskunde en de medische sociologie zijn bijvoorbeeld sterk geinteresseerd in het verzuim van verschillende diagnosegroepen, in de invloed op het verzuim van de verzekeringsarts, bedrijfsarts en huisarts en in de invloed van wachttijden voor specialistische behandelingen.

De arbeids- en organisatiepsychologie kent ook weer een eigen invalshoek. Deze houdt zich onder meer vaak bezig met de effekten op het verzuim van arbeidsmotivatie, arbeidssatisfaktie, stress, persoonlijkheidskenmerken, en dergelijke.

De organisatiesociologie tenslotte is in de eerste plaats geinteresseerd in de organisatiegewijze verschillen in het verzuim en de organisatiegebonden oorzaken. Men denke hierbij bijvoorbeeld aan produktieprocestypen, organisatie-omvang, organisatiestruktuur, omgevingskenmerken van organisaties, en dergelijke. De studie die in deze publikatie verslagen zal worden, heeft een organisatiesociologisch perspektief. Organisatiekenmerken staan er dus centraal in en typisch medische en psychologisch relevante determinanten van het ziekteverzuim, zoals hierboven globaal aangeduid, vallen in grote lijnen buiten de studie.

Met deze konstatering zijn we aangekamen bij het eerste van de vier wetenschappelijke hoofdkenmerken van het empirisch anderzoek, dat van deze studie de hoofdmoot zal vormen.

Het eerste kenmerk is dus de organisatievergeli.jkende benadering. Deze heeft overigens een aantal voor- en nadelen die in hoofdstuk 4 uitvoerig behandeld zullen worden. Onderzoek naar de oorzaken van verzuim, waarbij het individu de analyse-eenheid is, heeft bijvoorbeeld het nadeel dat typisch individuele kenmerken, warronder de gezondheidstoestand en de gezondheidsklachten, daarin zo'n overheersende rol spelen. Hierdoor zullen de gezochte sociaal-wetenschappelijke determinanten van het verzuim vaak slechts 
zwak herkenbaer zijn. In onderzoek waarbij men de groep, de af deling of de organisatie als analyse-eenheid hanteert, heeft men genoemd nadeel veel minder, omdat bij dit soort onderzoek het verzuim een gemiddelde mat is, warin juist de typisch individugebonden gezondheidsaspekten als het ware onder kontrole gehouden zijn.

De verschlllen in verzuim die men den nog 'overhoudt' zullen nog marr weinig medisch bepaald zijn en zullen veel meer niet-medische, in casu sociaal-wetenschappelijke achtergronden hebben.

Bovenstaande materie is door Philipsen (1970) behandeld naar aanleiding van het feit dat de relatie arbeidsvoldoening - verzuim op individueel nivo niet en op geaggregeerd nivo wel herkenbaar is. In hoofdstuk 4 wordt op de problematiek van de analysenivo's teruggekomen.

Het tweede kenmerk van het onderzoek heeft als achtergrond dat er in de onderzoeksliteratuur zo weinig expliciet replikatie-onderzoek voorkont, waarin men zich bezighoudt met de determinanten van ziekteverzuim.

Er is veel empirisch onderzoek beschikbaar over de mogelijke oorzaken van verzuim, maar hierbij wordt nogal vaak opnieuw 'het wiel uitgevonden', dat wil zeggen dat er steeds weer andere operationalisaties gebruikt worden van de te hanteren verklarende variabelen. Dit probleem is ook uitgebreid belicht in een recente literatuurstudie van het Nederlands Instituut voor Praeventieve Gezondheidszorg (NIPG/TNO), dat 318 empirische onderzoekingen uit de periode 1950 - 1982 samenvat (Smulders, 1984). Reeds meer dan twintig jear geleden merkte De Groot (1961, p. 142) over de sociaal-wetenschappelijke onderzoekspraktijk in Nederland het volgende op: "Men is vaak geneigd eigen theorieën ne te jagen en telkens weer lets 'interessants', nieuws te beproeven, in plaats van een konsekwente lijn te volgen; 'replikaties' van reeds eerder uitgevoerd onderzoek te verrichten ...; kortom: een steentje bij te dragen tot een reeds ontworpen en gedeeltelijk opgetrokken gebouw, in plaats van telkens weer een "eerste steen te leggen'." Hiermee is op beeldende wijze de waarde van replikatie-onderzoek beschreven. Door middel van herhaald onderzoek kunnen namelijk eerder geformuleerde hypothesen ontkracht, bevestigd en/of verder ontwikkeld worden, hetgeen een wezenlijke bijdrage vormt tot meer inzicht in de sociale werkelijkheid. Voorts heeft replikatie-on- 
derzoek het voordeel dat nagegaan kan worden of eerdere resultaten artefakten zijn van methodische aspekten van het eerder uitgevoerde onderzoek.

Uiteraard is replikatie-onderzoek alleen waardevol als het te herhalen oorspronkelijke onderzoek theoretisch en praktisch relevant is. Bovendien is replikatie-onderzoek alleen optimaal uitvoerbaar als het te herhalen oorspronkelijke onderzoek ook eenduidig beschreven is, zodat geen misverstanden kunnen ontstaan op methodisch terrein.

Het onderzoek naar de oorzaken van verschillen tussen bedrijven, dat door Philipsen in 1969 werd gepubliceerd, kwam daarom het meest in aanmerking voor het voorgenomen replikatie-onderzoek.

Het derde kenmerk van het onderzoek is de multivariate methode. Steers en Rhodes (1978) kwamen na uitvoering van een evaluatie van de Angelsaksische onderzoeksliteratuur op het gebied van het ziekteverzuim, tot de konklusie dat er een veelheid van bivariat en een groot gebrek aan multivariaat onderzoek bestond. Het nadeel van bivariaat onderzoek is dat niet duidelijk is of doorkruisende variabelen het gevonden verband mede bepaald hebben. Deze onduidelijkheid wordt in belangrijke mate geëlimineerd door de multivariate methode. Het bestaan van dit probleem werd ook gesignaleerd in de reeds vermelde Nederlandse literatuurstudie (Smulders, 1984).

In het in deze publikatie weer te geven onderzoek werd derhalve gekozen voor de multivariate analysewijze.

Tenslotte is het vierde hoofdkenmerk van deze studie, dat het om een toetsend onderzoek gaat. Er worden dus hypothesen geformuleerd aan de hand van theoretische inzichten en eerder empirisch onderzoek, welke op hun juistheid getoetst worden. Er is dus geen sprake van een beschrijvend onderzoek. Dat wil ook zeggen dat de resultaten wel inzicht geven in het al dan niet bestaen van verbanden tussen oorzakelijke variabelen en verzuimindices bij produktiebedrijven in Nederland, maar bijvoorbeeld geen inzicht geven in feitelijke verschillen in verzuim tussen produktiebedrijven in Nederland of in feitelijke verschillen in verzuim tussen bepaalde persineelskategorieën in ons land (bijvoorbeeld verschillen in verzuim tussen hoger respektleveli.jk lager opgeleiden, leeftijdsklassen, etcetera). Dat het om toetsend en niet om 
beschrijvend onderzoek gaet, betekent ook dat het vraagstuk van representativiteit van de steekproef van ondergeschikt belang is. Hierop wordt in hoofdstuk 3 nog teruggekomen.

De boven beschreven vier kenmerken van het onderzaek betekenen, samengevat, dat een toetsend onderzoek met multivariate methode wordt verricht naar de oorzaken van verschillen in ziekteverzuim tussen organisaties, waarbij een deel van het onderzoek zal bestaan uit de replikatie van eenzelfde soort onderzoek dat in de jaren 1964/65 werd uitgevoerd door Philipsen (1969).

Tot de probleemstelling van het in deze publikatie te beschrijven onderzoek behoren de volgende vragen.

Vertonen de door Philipsen in 1964/65 gebruikte negentien sociaal-wetenschappelijke variabelen om de verschillen in verzuim tussen bedrijven mee te verklaren, in 1980/81 verbanden van ongeveer gelijke sterkte met het verzuim? ofwel, hoe is de stabiliteit van de determinanten? Wat betekenen de resultaten voor de theorie die Philipsen opstelde om verschillen in verzuim tussen bedrijuen te verklaren?

In hoofdstuk 6 worden de antwoorden op deze vragen geformuleerd. Het empirisch onderzoek zal echter niet alleen uit replikatie bestaan. In hoofdstuk 7 worden namelijk nog twee vragen beantwoord: Welke andere variabelen zijn van belang voor de verklaring van de verschillen in verzuim tussen bedrijven? Indien deze andere mogelijke determinanten toegevoegd worden aan de meest valide en betrouwbare van de oorspronkelijke negentien verklarende variabelen, blijven de oorspronkelijke variabelen dan hun belang behouden of worden ze als het ware "onderdrukt" door de toegevoegde?

De wetenschappelijke betekenis van het onderzoek dient uiteraard gezocht te worden in de antwoorden op de hierboven geformuleerde vragen.

Tenslotte dienen nog twee minder belangrijke aspekten van de studie vermeld te worden. Een groot deel van het onderzoek betreft, zoals vermeld, de replikatie van het in 1964/65 uitgevoerde onderzoek van Philipsen. Alvorens het replikatie-onderzoek te starten is overleg gepleegd met deze auteur ten einde de replikatie optimaal te doen verlopen. Daarbij moest vastgesteld worden dat de door hem gebruikte vragenlijsten een aantal jaren na afloop van zijn onderzoek vernietigd waren. Toch bleek dit uiteindelijk 
niet tot grote problemen te leiden, ondat de verslaglegging van het oorspronkelijke onderzoek voldoende systematisch was vastgelegd in de betreffende publikatie, zadat zonder al te veel moeite de voor de operationalisering van de variabelen gebruikte vragen daeruit gedlestilleerd konden worden.

Een laatste te vermelden punt is, dat de term 'afwezigheid wegens ziekte' in deze studie niet gebruikt zal worden. Men kan het met Philipsen (1969) eens zijn dat deze term niet de negatieve bijklank heeft die de termen 'verzuim' en 'ziekteverzuim' voor sommigen wel hebben. Omdat echter deze laatste termen sterk ingeburgerd zijn in het spraakgebruik, is daar toch bij aangesloten. Verder zal er geen onderscheid gemaakt worden tussen 'verzuim" en 'ziekteverzuim'. Beide begrippen zullen dus als synoniemen door elkaar heen gebruikt worden. De verzuimmaten worden in paragraaf 5.5 gedefinieerd en besproken.

\subsection{De opbouw van deze publikatie}

Het hierna volgende hoofdstuk 2 bevat een historisch overzicht van de theorievorming met betrekking tot ziekteverzuim. Het hoofdstuk begint met de beschrijving van enige niet-specifiek op verzuim gerichte hypothesen en theorieën, die gebruikt zijn om verzuim mee te verklaren en eindigt met enige specifiek op verzuim gerichte hypothesen en theorieën.

Hoofdstuk 3 geeft de opzet van het empirisch onderzoek weer. Achtereenvolgens worden beschreven: de onderzochte bedrijiven, de wijze van materiaalverzameling, de wijze van reduktie van het verzamelde materiaal tot variabelen, het onderzoeksplan en de analysetechnieken.

Omdat in het onderzoek arganisaties de studie-objekten zijn, wordt in hoofdstuk 4 de invloed van het analysenivo (individueel of geaggregeerd) op de resultaten aan de orde gesteld. Besproken wordt welke voor- en nadelen er aan beide benaderingen vastzitten.

Hoofdstuk 5 beschrijft de 32 in het onderzoek gebruikte verklarende variabelen. Bij elke variabele wordt weergegeven hoe de meting plaatsvond en welk verband met de verzuimfrekwentie en de gemiddelde verzuimduur per geval verondersteld wordt.

Nagegaan wordt welke verschillen er bestaan tussen het oorspron- 
kelijke en het replikatie-onderzoek op het punt van respektievelijk de analyse-eenheden, de wijze van materiaal-verzamelen, de inhoud van de variabelen en de waarden van de variabelen. Deze verschillen kunnen in principe de te vinden verschillen in de resultaten duidelijk maken. Dit hoofdstuk eindigt met een beschrijving van de drie afhankelijke variabelen: de verzuimfrekwentie, de gemiddelde verzuimduur en het verzuimpercentage.

Hoofdstuk 6 bevat de zogenaande replikatie-analyse. Deze heeft betrekking op de negentien variabelen die zowel in 1964/65 als in $1980 / 81$ gemeten werden. Weergegeven wordt de onderlinge samenhang van de negentien verklarende variabelen en hun verband met de drie verzuimmaten. De gevonden resultaten worden besproken in het licht van de geformuleerde hypothesen.

Hoofdstuk 7 heeft betrekking op de zogenaamde vervolganalyse, warbij acht van de oorspronkelijke negentien variabelen om diverse redenen geëlimineerd en dertien nieuwe variabelen toegevoegd worden. Ook hier wordt weer de ondelinge samenhang van de 24 variabelen, alsmede hun relaties met de drie verzuimmaten, geanalyseerd. Opnileuw worden de resultaten besproken tegen de achtergrond van de oorspronkelijke hypothesen. Bovendien worden de tot zeven faktoren samengevoegde 24 variabelen in verband gebracht met de verzuimmaten. Dit biedt de gelegenheid de resultaten te integreren. Tenslotte vinden er in hoofdstuk 7 enige analyses plaats van kausale madellen met behulp van de LISREL-techniek.

Hoofdstuk 8 tenslotte bevat een slotbeschouwing over de betekenis van de gevonden resultaten. 


\subsection{Struktuur en doel van dit hoofdstuk}

Verscheidene auteurs hebben erop gewezen dat er een zeer grote hoeveelheid empirisch onderzoeksmateriaal beschikbaar is op het gebied van verzuim, maar dat expliciete theorie met betrekking tot het verschijnsel zeer dun gezaaid is. Het meeste empirisch onderzoek werd uitgevoerd zonder of an de hand van één of een paar hypothesen. Wel is een beperkt deel van het verzuimonderzoek geplaatst binnen het kader van wat meer algemene theorieën over gedrag in organisaties (waarin verzuim dus één van de afhankelijke variabelen is), maar onderzoek dat plaatsvond op basis van een expliciete verzuimtheorie is op de vingers van twee handen te tellen.

Een theorie wordt hier gedefinieerd als een min of meer samenhangend stel uitspraken over een bepaald gedeelte van de werkelijkheid, terwijl één zo'n uitspraak een hypothese genoemd kan worden. Het verschil tussen een hypothese en een theorie ligt dus in het feit dat de eerste een meer eenvoudig en de laatste een min of meer complex of uitgewerkt karakter heeft.

Dm enige lijn te brengen in de voorhanden zijnde theoretische uitspraken met betrekking tot verzuim, zal hieronder een indeling aangehouden worden met twee ingangen. Enerzijds wordt anderscheid gemaakt tussen hypothesen en theorieën. Anderzijds worden meer op algemeen gedrag in organisaties (en dus niet-specifiek op verzuim) gerichte hypothesen/theorieën onderscheiden van specifiek op verzuim gerichte hypothesen/theorieën. Hierdoor ontstaan vier te onderscheiden soorten hypothesen/theorieën:

- niet-specifiek op verzuim gerichte (organisatie)hypothesen (te beschrijuen in $\S 2.2$ );

- niet-specifiek op verzuim gerichte (organisatie)theorieen $(\$ 2.3)$;

- specifiek op verzuim gerichte hypothesen (\$ 2.4 );

- specifiek op verzuim gerichte theorieën (\$2.5).

Deze indeling is gekozen omdat er aansluiting mee ontstat op de geschiedenis van het denken over verzuim. Dit ontwikkelde zich namelijk in grote lijnen van eenvoudig nar complex of uitgewerkt 
en van niet-speciflek naar wel-specifiek op verzuim gericht, hoewel ook thans nog steeds eenvoudige, niet-specifiek op verzuim gerichte theorieën en hypothesen in gebruik zijn om ziekteverzuim mee te verklaren.

Behalwe de theorieën en hypothesen zelf, zal getracht worden de empirische toetsing ervan - voor zover die in enigerlei vorm heeft plaatsgevonden - sumier te vermelden. Verifikatie en falsifikatie van theorieën zijn trouwens ingewikkelde bezigheden. Allereerst moet een theorie 'goed' geformuleerd zijn. Dat wil zeggen dat deze toetsbaar, eenvoudig en logisch konsistent opgesteld is en dat het 'domein' warap de theorie betrekking heeft duidelijk weergegeven is. De eis wan toetsbaerheid betekent dat de theorie, tenminste op een aantal punten, op basis van konkrete hypathesen, door empirisch onderzoek te toetsen valt.

Dit alles is bij veel theorieën niet het geval. Maar zelfs als het wel het geval is, kan verifikatie door onvoorziene omstandigheden of 'storende' faktoren nog mislukken. Bovendien kunnen onjuiste operationalisaties voor de betreffende variabelen gebruikt zijn, onjuiste warnemingen gedaan, de resultaten onjuist geïnterpreteerd, etcetera, etcetera. In het algemeen is falsifikatie van een theorie zo goed als altijd mogelijk: er zijn altijd wel 'gevalien die niet uitkomen'.

Zaals De Groot (1961, hoofdstuk 4.2, maar ook in latere publikaties) uitvoerig beschrijft, komt het er witeindelijk op neer dat "het forum" (de ter zake kundige wetenschappers) een theorie na verloop van tijd al dan niet 'au sérieux' neent. Hierbij speelt vergelijking met andere, op dezelfde verschijnselen betrekking hebbende, theorieën een erg belangrijke rol. Kortom: de beslissing over anvarding of verwerping van theoriën blijft prowisorisch.

Er zijn ook talrijke theorieën geformuleerd waraan "het forum" nooit toegekomen is, dus waer nooit een 'beslissing' over genomen is. Het gaat er in dit hoofdstuk daarom in de eerste plaats om de historie van het denken over verzuim te schetsen en pas in de tweede plaats om aannemelijk te maken welke theorieën juist af onjuist zouden kunnen zijn, voor zover dit latste mogelijk is. De konklusies uit dit theoretische hoofdstuk zijn op zich van belang, maar zullen in deze studie ook gebruikt worden om de gevonden onderzoeksresultaten (hoofdstuk 6 en 7) tegen af te zetten. Voor de duidelijkheid moet hier voorts nog benadrukt worden dat 
dit hoofdstuk niet handelt over 'gedrag van werknemers in organisaties' in het algemeen. Personeelsverloop, het verrichten van kwalitatief en kwantitatief goed werk, ongelukken maken, te laat komen, staking van het werk, etcetera, zijn gedragingen die vaak in één adem met verzuim worden genoemd. Uit nader onderzoek blijkt echter meer en meer dat er veel verschil in oorzaak is. Eén integrale theorie over gedrag van werknemers in organisaties verdwijnt daarom steeds meer achter de horizon en een poging iets dergelijks wel na te streven zal hier dan ook niet ondernomen worden.

2.2 Niet-specifiek op verzuim gerichte (organisatie-)hypothesen

In deze kategorie kunnen gerangschikt worden de hypothesen betreffende de relaties van arbeidssatisfaktie, 'commitment', 'identifikatie', 'involvering', werkmotivatie, moreel en stress met verzuim. Behalve het feit dat deze begrippen niet-specifiek op verzuim gericht zijn, maar daar wel mee in verband gebracht, hebben ze gemeen dat ze over het algemeen geaccepteerd zijn om de relatie tussen individu en arganisatie te beschrijven. In de meeste gevallen gaat het eigenlijk slechts om één hypothese, bijvoorbeeld: arbeidssatisfaktie hangt negatief samen met gedrag waaronder ziekteverzuim - van werknemers in organisaties.

Allereerst het begrip arbeidssatisfaktie, dat heel vaak gebruikt is om gedrag in organisaties, waaronder verzuim, mee te verklaren. Tientallen auteurs hebben onderzoek gedaen naer de relatie tussen verzuim en arbeidssatisfaktie in het algemeen of aspekten daervan (zoals satisfaktie met de konkrete werkinhoud, de leiding, de kollega's, de werkomstandigheden en de beloning). Nicholsan et al. (1976) hebben 29 van zulke studies geïnventariseerd en kwamen tot de konklusie dat de relatie zwak genoend moet worden. Smulders (1984) konkludeerde, op basis van een omvangrijke literatuurstudie, dat er wel een verband is tussen satisfaktie met de leiding, kollega"s, loon en promotiemogelijkheden en het verzuimpercentage/de frekwentie. Interveniërende variabelen als gezondheid (Philipsen, 1970), involvering in het werk (Wood, 1974) en verzuimgelegenheid (Smith, 1977) spelen een rol in de 
relatie arbeidsatisfaktie - verzuim.

Een tweede, vaak in Amerikaans orgenisatie-psychologisch onderzoek gebruikt begrip am de relatie tussen het individu en de organisatie mee te beschrijuen is 'organizational commitment of 'organizational identification'. Door de auteurs zelf worden de begrippen meestal aangeduid met "de bedoeling om in de organisatie te blijuen en hard te willen werken'. De Nederlandse termen zich-inzetten-voor of zich-verplichten-tot lijken er het dichtst bij te komen.

In acht bronnen is de relatie met verzuim onderzocht (Patchen, 1965, 1970; Steers, 1977; Angle \& Perry, 1981; Hammer et al., 1981; Jamal, 1981; Rhodes \& Steers, 1981; Terborg et al., 1982). $E_{r}$ wordt een duidelijke oververtegenwoordiging van negatieve verbanden door deze auteurs gevonden.

Zools Steers (1977) ook opmerkt, hebben deze koncepten een persoons- en een organisatie-komponent; dus zowel individuele als bedrijfskenmerken zijn dan oak ven invloed op de relatie van deze variabelen met verzuim.

Een derde begrip dat in dit verband van belang is, is "job involvement", ofwel de mate van belang die de werknemer hecht aan zijn werk of de mate waarin deze zich betrokken voelt bij het werk. Het gaat hier dus niet om de organisatie of de organisatiedoeleinden, maar om het werk of de taak zelf. Bovendien ligt het alksent niet op het zich-verplichten-tot maar op het zich-betrokken-voelen-bij.

In elf studies is nagegaan welke de relatie is met verzuim (Hackman \& Lawler, 1971; Siegel \& Ruh, 1973; Mirvis \& Lawler, 1977; Beehr \& Gupta, 1978; Saal, 1978; Orpen, 1979; Algera, 1980; Blumberg, 1980; Chelohe \& Farr, 1980; Breaugh, 1981; Hammer et al., 1981). Het resultaat was opnieuw dat er een duidelijke oververtegenwoordiging van negatieve verbanden met het verzuimpercentage en/of de frekwentie werd gevonden. De mate van involvering in of zich betrokken voelen bij het werk kan samenhangen met verschillen tussen individuen, maar ook met verschillen tussen bepaalde taakkenmerken. Dat is de kern van het begrip - de relatie tussen het individu en de organisatie - maar tevens thet nadeel ervan: men weet niet in welke mate het iets zegt over de werknemer en in welke mate over zijn werksituatie. 
Een vierde begrip dat uit de orgenisatie-psychologie/sociologie stamt en dat ook gebruikt is om verzuim mee te verklaren, is het begrip intrinsieke werkmotivatie (om goed te willen werken, voegen Hackman en Lawler, 1971, eraan toe). Vijf bronnen tonen allemaal een negatief verband met het verzuimpercentage en/of de frekwentie (Hackman \& Lawler, 1971; Mirvis \& Lawler, 1977; Wall et al., 1978; Orpen, 1979; Algera, 1980).

Ten vijfde zou nog het wat verouderde begrip 'morale' (moreel) vermeld kunnen worden. Het is over het algemeen een groepskenmerk en ook in verband gebracht met verzuim. Dit paraplu-begrip bestaat meestal uit meerdere elementen, waaronder de satisfaktie van de werknemers, de stijl van leidinggeven van de baas en groepscohesie (Bernberg, 1952; Motowidlo \& Borman, 1978). Genoemde auteurs vonden in hun onderzoekingen (respektievelijk op individueel en op groepsniva) geen signifikante verbanden tussen moreel en de verzuimf rekwentie of het verzuimpercentage.

Tenslotte werd het vage, doch populaire begrip stress gebruikt om verzuim mee te verklaren (onder anderen door Patchen, 1970; Rousseau, 1978; Gupta \& Beehr, 1979; Karasek, 1979; Reiche \& Van Dijkhuizen, 1979; Algera, 1980; Van Dijkhuizen, 1980; Houben, 1981). De meeste auteurs stellen het begrip ongeveer gelijk aan belasting, rolproblemen, extreme taak-/produktie-eisen of zelfs klachten in het algemeen. Meestal wordt er een positief verband gevonden tussen stress en verzuim, maar interveniërende variabelen als 'persoonlijkheid', beslissingsvrijheid in het werk, besturingsmethoden en 'support' van leiding, kollega's en verwanten bleken als kanditionerende krachten op te kunnen traden.

Op basis van het verrichte empirisch onderzoek kan hier als samenvatting gelden dat de verbanden wan de hierboven beschreven begrippen - die alle iets van de relatie tussen de werknemer en de organisatie beschrijven - met verzuim over het algemeen wel, soms zwak, aanwezig zijn. De begrippen hebben het nadeel dat niet duidelijk is in welke mate ze persoons- respektievelijk bedrijfsgebonden zijn. De beperktheid van de hierboven beschreven begrippen als het gaat om de verklaring van het ziekteverzuim, zal in latere paragrafen (bijvoorbeeld $\S 2.5$ ) van dit hoofdstuk duidelijk worden gemaakt. 
In deze kategorie zullen achtereenvolgens behandeld worden de ruiltheorie, de billijkheidstheorie, de verwachtingstheorie, roltheorieën, leiderschapstheorieën en taakgerichte onderzoeksmodellen. Hiervan zijn de eerste drie mér zagenaamde procesachtige theorieën (Campbell et al., 1970) die vooral iets zeggen over de wijze waarop motivatie, satisfaktie of verzuim ontstaan, terwijl de laatste drie theorieën als het ware meer inhoudelijke theorieen zijn, die vooral de vraag beantwoorden welke variabelen satisfaktie, verzuim, etcetera beïnvloeden.

\section{De ruiltheorie}

In de sociologie zijn ruiltheorieën uitgewerkt door onder anderen Homans en Blau. De kern van deze theorieën is dat allerlei gedrag wordt opgevat als een gevolg van ruilprocessen tussen personen of tussen groepen of tussen personen en groepen. De ruil kan betrekking hebben op materiële zaken zoals geld en niet-materiële zaken zoels gevoelens (bijvoorbeeld goedkeuring of afkeuring). Ruilrelaties kunnen alleen plaatsvinden bij keuzemogelijkheden - dwangrelaties vallen er dus niet onder - en personen worden geacht die ruilrelaties aan te gaan die het beste hun behoeften bevredigen. March en Simon (1958, p. 83-111) hebben het gedrag van mensen in organisaties binnen de ruiltheorie geplaatst (overigens zonder de term rull te gebruiken; $z i j$ spraken van 'organizational equilibrium"). De balans tussen de 'bijdragen" van werknemers en de 'lokmiddelen' of 'prikkels' van de organisatie bepaalt, in hun visie, de mate van satisfaktie en participatie, waronder zij produktie, verloop en verzuim van de werknemer rekenen. Dus werknemers beoordelen hun arbeidssituatie op een groot antal aspekten en zetten de opbrengsten (beloning, prestige) daarvan af tegen hun eigen investeringen en kosten (opleiding, arbeidstijd), hetgeen via gebrek aan satisfaktie tot verzuim kan leiden. In deze opvatting zijn satisfaktie en verzuim dus netto-effekten of saldo's. March en Simon voegen er echter wel aan toe dat de ruil niet plaatswindt als er sterke sankties staan op verzuim of indien werkloosheid het RISICO van verzuim te groot meakt, dus indien de verzuimgelegenheid als erg gering wordt ervaren. Chadwick-Jones et al. (1982) hebben zich in hun boek sterk voor- 
stander getoond van de ruiltheorie als verklaring van verzuim. Zij vatten verzuim op als onderdeel van de ruil zelf, dus niet als effekt of saldo van input en output, maar als een "negatief betaalmiddel ". Bovendien menen zij dat de ruil tusen individu en management geplaatst moet worden in het kader van werkgroepnormen, die de evaluatie van de input en output door de individuele werknemers konditioneren.

Hun voorkeur voor deze theoretische benadering en kritiek op andere is echter matig beargumenteerd.

Dok een later te behandelen auteur, als Gibson (1966), denkt sterk vanuit de ruilrelatie tussen individu en organisatie.

Als konklusie kan hier vermeld worden dat er niet één ruiltheorie is, mar meerdere met verschillende opvattingen over welke elementen wel en welke niet tot de ruil behoren (bijvoorbeeld ekonomische en psychische aspekten). Ten tweede is de ruiltheorie niet toetsbaar uitgewerkt, tenzij men meent dat een negatief verband tussen de hoogte van het salaris en het verzuim een 'bewijs' voor de ruiltheorie is. Aantonen dat werknemers de relatie met hun bedrijf/direktie als een ruil opvatten vergt echter meer. Falsifikatie door middel van empirisch onderzoek is dus vooralsnog niet goed mogelïjk. Ten derde zijn in organisaties de verhoudingen lang niet altijd vrij van dwang, waardoor van vrije keuzen in het kader van de ruil niet altijd sprake kan zijin. Tenslotte is het de vreag of werknemers in organisaties altijd naar maximalisering van hun zogenaamde input - output-balans streven en of dat niet voor ledereen wat anders betekent, zodat maximalisering ook niet objektief vast te stellen is.

\section{De billijkheidstheorie}

De door Adams (1965) ontwikkelde billijkheids- of rechtvaardigheidstheorie (equity theory) is een ultwerking van de ruiltheorie. In deze theorie gaat het ook om de verhouding tussen inzet en opbrengst, zoals die ervaren wordt door de werknemer. Adams voegde er echter aan toe dat de balans tussen inzet en opbrengst door de werknemer gepercipleerd wordt met behulp van socilale vergelijkingsprocessen met zogenaande referentiepersonen of -groepen, bijwoorbeeld kollega's of werknemers van andere bedrijven. Dnbillijkheid kan in deze theorie ook gevaeld worden als de opbrengst groter is dan de input, bijvoorbeeld bij overbetaling. 
Onballans of gevoelens van onbillijkheid leiden tot dissatisfaktie of dissonantie en de wens tot dissonantie-reduktie (Festinger, 1957).

Er zijn, volgens Adams, zes methoden on de dissonantie te reduceren: (1) de werknemer kan zijn inzet beperken; (2) kan trachten zijn opbrengst te (doen) verhogen; (3) kan de balans inzet/opbrengst denkbeeldig bijstellen; (4) kan zich door middel van vertrek of verzuim aan de vergelijking onttrekken; (5) kan ervoor zorgen dat de balans van de vergelijkingspersonen verandert, bijvoorbeeld door te zorgen dat de kollega's minder hard werken; en (6) kan een andere referentiepersoon of -groep kiezen om zich mee te vergelijken.

In deze theorie is ziekteverzuim dus een vluchtmechanisme om aan een onbillijke situatie te ontkomen en niet een onderdeel van de 'inzet'. Bovendien zegt de theorie dat verzuilm maar één van de middelen is on de spanning te reduceren die het gebrek aan evenwicht veroorzaakt, hetgeen een opvallend aspekt van de theorie is.

Aangetoond is dat onbillijkheidsgevoelens met betrekking tot beloning, leiding, werktempo en dergelijke het verzuim stimuleren (Patchen, 1960; Dittrich \& Carrell, 1979), vooral indien vergelijkingen worden gemaakt met referentiepersonen of -groepen buiten de eigen organisatie. Dit is overigens nog geen bewijs voor de geldligheid van de billijkheidstheorie voor de verklaring van verzuim.

Empirisch onderzoek met betrekking tot de omstandigheden waaronder voor verzuim of voor een van de andere reaktiemethoden wordt gekozen, is er niet. Ook is onduidelijk welke referentiepersonen of -groepen gekozen worden voor vergelijking van de eigen input. en output. Tenslatte zijn individuele verschillen in de billijkheidstheorie onderbelicht.

\section{De verwachtingstheorie}

De derde theorie met betrekking tot gedrag in organisaties, die ook andacht besteedde aen verzuim is de 'expectancy theory". Deze verwachtingstheorie dateert al van voor de tweede wereldoorlog en is niet zozeer aan één auteur te koppelen.

Echter, Vroom (1964) heeft er waarschijnlijk op het gebied van het organisatiegedrag de meeste bekendheid aan gegeven. Zeer summier gesteld, gaat de theorie allereerst uit van het idee dat de 
werknemers bepaalde opbrengsten, ook gevolgen van gedrag genoemd, prefereren boven andere. De ene opbrengst (bijvoorbeeld promotie) is attraktiever, geeft meer satisfaktie dan de andere. De term 'valentie' wordt in de verwachtingstheorie gebruikt voor de attraktiviteit van bepaalde opbrengsten of gedragsgevolgen.

Een tweede aspekt van de theorie is dat mensen een zeker idee hebben van de waarschijnlijkheid (als 'verwachting' betiteld), dat bepaald gedrag inderdaed zal leiden tot een gewenst gevolg/ opbrengst; bijvoorbeeld weinig verzuimen of goede prestaties leveren leidt al dan niet tot promotie.

Ontdaan van alle details wordt in deze motivatietheorie de motivatie tot gedrag bepaald door het produkt van (1) de attraktiviteit of valentie van de opbrengst of het gedragsgevolg, en (2) de verwachting of verwachte kans dat het gedrag inderdaad tot het gevolg leidt.

Wat nu het verzuim betreft stelt Vroom (1964, p. 178) dat werknemers als het ware iedere dag opnieuw beslissen of ze aanwezig of afwezig zullen zijn. De uitkomst van deze beslissing zal afhangen van de verwachte gevolgen van het aan- of afwezigheidsgedrag in termen van satisfaktie bijvoorbeeld. Met andere woorden, hoe groot wordt de kans geschat dat aanwezigheid tot satisfaktie zal. leiden, is volgens Vroom de vraag die men zich steeds stelt. Satisfaktie met het werk en dergelijke is dus in deze denkbeelden een globale indikatie voor de kans op aanwezigheid.

Morgan en Herman (1976) zijn de enigen geweest die de verwachtingstheorie daadwerkelijk op verzuim hebben toegepast. Ze zijn op een originele wijze - en subtieler den de publikatie van Vroom zou doen vermoeden - te werk gegaan. Ze vroegen 60 werknemers van twaalf in principe attraktieve gevolgen van verzuim (zoals vrije tijd, karweitjes doen, zieken thuis kunnen verzorgen, en vervoersproblemen vermijden) en van tien in principe niet-attraktieve gevalgen van verzuim (zoals verlies van inkomen en uitkeringen, disciplinalre matregelen, kollega's moeten harder werken) aan te geven welke (1) het belang (valentie) en (2) de waarschijnlijkheid zouden zijn bij hun eventuele afwezigheid. Deze uitslagen werden gekorreleerd met de verzuimfrekwentie en het resultaat was dat vooral de attraktieve konsekwenties met de verzuimfrekwentie bleken samen te hangen. Dus: gedrag (verzuim) hangt inderdaad af van de perceptie van de kans op een aantal maar lang niet alle - attraktieve konsekwenties en van de kans op 
niet-attraktieve gevolgen, bijvoorbeeld verlies van uitkering. De kritiek op de verwachtingstheorie is geweest dat deze - net als in de ruiltheorie - de mensen ziet als sterk rationeel beslissende wezens, bijvoorbeeld ten aanzien van aan- en afwezigheid. Het is echter waarschijnlijker dat oak allerlei minder bewuste beslissingen een rol spelen in het gedrag van werknemers in organisaties. Bovendien is het de vraag of werknemers altijd voor hen attraktieve opbrengsten nastreven. Volgens de billijkheidstheorie zijn er andere gedragsalternatieven mogelijk.

\section{De roltheorie}

Een meer inhoudelijke organisatiegedrag-theorie, waarin verzuim opgenomen werd als afhankelijke variabele, is de roltheorie (zie bijvoorbeeld Van de Vliert, 1974).

Zowel in de sociologie als in de sociale psychologie kent men deze benadering. Van een eenduidig uitgewerkte theorie is evenwel geen sprake; het gaat meer om een aantal hypothesen, deeltheorieen en geïsoleerde begrippen, waarbij het begrip rol een centraal element is.

Onder sociale rol kan het gedrag verstaan worden dat conform bepaalde normen verwacht mag worden van iemand die een bepaalde positie inneemt. Op de organisatie toegespitst, gaat het om het gedrag dat de organisatie van de werknemer eist. Bij de positie van voorman, direkteur, operator, etcetera hoort dus een bepald verwacht rolgedrag, hetgeen overigens nog kan verschillen van de feitelijke vertolking.

Rolkonflikten ontstaan onder andere wanneer van verschillende kanten tegengestelde eisen gesteld worden, bijvoorbeeld bij de man van de technische dienst die van zijn bass opdracht krijgt om een machine zo goed moge $\mathbb{i j k}$ te herstellen, terwijl de produktiechef vooral snelheid, en in mindere mate precisie, geboden acht bij het herstel. Hier is sprake van een zogenaamd intern rolkonflikt. Het ondernemingsraadlid dat enerzijds te maken heeft met de verwachtingen van zijn direkteur en anderzijds met die van zijn achterban zit ook in een intern rolkonflikt.

Een extern rolkonflikt ontstaat wanneer één persoon twee posities bekleedt, ten anzien warvan tegengestelde verwachtingen bestaan, bijvoorbeeld vrouwelijke werknemer en moeder van een paar kinderen.

Aan het oplossen van rolkonflikten (bijvoorbeeld door prioriteit 
toe te kennen aan één rol, door het zoeken naar een kompromis of door het miniseren van het rolgedrag) is in de onderzoeksliteratuur veel aandacht besteed.

Bij sommige rollen is het gedrag dat verwacht wordt zeer duidelijk; bij andere rollen is er veel meer ruimte voor eigen interpretatie. Dat laatste hoeft niet, maar kan soms tot grote onzekerheid leiden bij de rolbekleder, bijvoorbeeld wanneer het gedrag steeds, met het oog op allerlei onvoorziene situaties, bijgesteld dient te worden.

Rolambiguïteit bestaat als een rolbekleder onvoldoende informatie heeft voor het adekwaat vervullen van zijn rol. Het is de rolbekleder den onduidelijk wat zijn taak en verantwoordelijkheden zijn. Rolspanningen en rolonzekerheid, die het gevolg zijn van rolkonflikten en rolambiguiteit, zijin vooral in stress-onderzoek belangrijke onderzoeksonderwerpen geworden. In roltheoretisch onderzoek wordt ziekteverzuim, samen met spanning en onzekerheid, vaak gezien als reaktie op rolkonflikten, rolambiguiteit, roldruk (role pressure) en roloverbelasting (role overload).

Oldham en Wild (1979) en Schokking-Siegerist (1979) hebben daar het meest expliciet gebruik van gemaakt, door hun onderzoek naar ziekteverzuim van vrouwelijke werknemers sterk te koncentreren rond het interne en externe rolkonflikt van de werkende vrouw. Zij beargumenteerden dat een konflikt tussen de vrouwenrol en de werknemersrol vaak direkt samenhangt met het verzuim.

Dok andere auteurs hebben rolbegrippen gebruikt bij de verklaring van verzuim. Ilgen en Hollenback (1977) en Fitzgibbons en Moch (1980) gebruikten bijvoorbeeld roldruk, Karasek (1979) konflikterende taakeisen en taakwrijheid, Patchen (1970) onduidelijkheid van instrukties, overbelasting in het werk, de moeilijkheid om de juiste hulpmiddelen, informatie en materiaal te krijgen voor de taakuitoefening en dergelijke, en Gupta en Beehr (1979) rolambiquiteit, rolkonflikt en roloverlading. Over het algemeen blijken deze variabelen een positief verband met verzuim (frekwentie) te vertonen, warmee het belang van de roltheorie voor de verklaring van het verzuim benadrukt wordt.

\section{Leiderschepstheorieën}

Vervolgens worden hier enige centrale thema's uit de leiderschapstheorie belicht die van belang zijn voor de verklaring van verzuim. 
Aan de relatie leiderschapsgedrag - ziekteverzuim is vrij vaak aendacht besteed in leiderschapstheorieën. De studies van de Ohio State University (Stogdill \& Coons, 1957) en van het Survey Research Center van Michigan Uníversity (zie Likert, 1961) in de vijftiger en zestiger jaren hebben hierin een belangrijke rol gespeeld. Men heeft bijvoorbeeld de polariteit demokratisch - autoritair leiderschap en de twee dimensies intrumenteel en socioemotioneel (of sociaal) leiderschap onderscheiden. Instrumenteel leiderschap heeft betrekking op de organisatie en uitvoering van het werk en de arbeidsprestatie, terwijl sociaal leiderschap betrekking heeft op het verkleinen van de afstand tot de ondergeschikten, kommunikatie, aanmoediging, etcetera.

Uit veel empirisch onderzoek (zie Philipsen, 1969, alsmede hoofdstuk 5 van deze studie) blijkt het belang van demokratisch, sociaal en instrumenteel leiderschap voor ziekteverzuim.

In de zeventiger jaren zijn zogenaamde pad - doel - leiderschapstheorieën ontwikkeld met sociaal en instrumentaal leiderschap als uitgangspunt. Dit zijn motivatie $\rightarrow$ prestatie $\rightarrow$ satisfaktiemodellen, warin leiderschap de motiverende rol speelt ten opzichte van prestatie en satisfaktie en warin persoonskenmerken van ondergeschikten (bijvoorbeeld behoeften) en taakkenmerken als konditionerende variabelen optreden. Het belang van de persoonsen taakkenmerken toont ook aan dat rechtstreekse verbanden tussen leiderschap en houdingen en gedrag (zoals verzuim) van ondergeschikten niet altijd verwacht mogen worden.

Johns (1978) toonde het konditionerend effekt van de taak duidelijk aan in de relatie van sociaal en instrumenteel leiderschap met verloopgeneigdheid. Met verzuim was dat echter niet het geval. Sociaal leiderschap korreleerde namelijk direkt negatief met verzuimf rekwentie.

Tenslotte dient nog vermeld te worden dat er thans ook aanwijzingen zijn (onder andere Szilagyi, 1980) dat de hoogte van het verzuim ook een kausale invloed kan hebben op het leiderschapsgedrag. Er kan dus sprake zijn van wederzijdse invloed.

\section{De socio-technische systeemtheorie}

Twee takgerichte modellen hebben met name zliekteverzuim als afhankelijke varlabele opgenomen. Het gaat hier om de socio-technische systeembenadering en het Job Characteristics Model wan Hackman en 0ldham (1976). 
In de open socio-technische systeemtheorie - die werd ontwikkeld in de zestiger jaren door medewerkers van het Londense Tavistock Institute - wordt gedrag in organisaties opgevat als effekt van de wisselwerking tussen het sociale systeem (de werknemers met hun behoeften en de relaties tussen hen) en het technisch systeem (de machines en het produktieproces) van de organisatie. Voorts wordt dit geheel onder invloed geacht te staan van en invloed uit te oefenen op de organisatie-omgeving.

De wisselwerking tussen de sociale en de technische kant van de organisatie, alsmede die tussen dit geheel en de omgeving $z i j n$ in deze benadering essentieel. Bovendien duiden deze twee zaken ook het verschil aan met eerdere, meer eenzijdige benaderingen van organisatie-analyse. Vertegenwoordigers ven de soclo-technische richting legden er de nadruk op dat bij het ontwerpen van het produktieproces en de taken daarbinnen rekening gehouden dient te worden met de menselijke behoeften aan afwisseling, kontakt, zelfrealisatie, etcetera.

Arbeidsdissatisfaktie, vervreemding, verloop en ziekteverzuim worden in deze benadering gezien als effekten van het niet-rekening houden met bedoelde menselijke behoeften in taken en werkorganisatie. Taakverrijking, taakroulatie, groepstaken, en dergelijke werden als oplossingen naar voren geschoven.

Hoewel er nogal wat kritiek op de benadering is geweest, onder andere betreffende de weinig scherpe definiëring van begrippen en de onmogelijkheid om het sociale en technische systeem gezamenlijk de 'optimaliseren', heeft deze aanpak toch het voordeel gehad dat aandacht gevestigd is op de wederzijdse relatie tussen menselijke behoeften en takkinhoud/produktieproces.

In sommige socio-technische onderzoekingen (onder anderen Trist et al., 1963; Allegro, 1973) is het verband taakinhoud - ziekteverzuim wel, in andere (Van Beinum, et al., 1967; Den Hertog en Vossen, 1974) niet vastgesteld. Toegevoegd dient echter te worden dat in het empirisch onderzoek zeif maar weinig aandacht is besteed aan de behoefte-verschillen tussen werknemers die - juist volgens de theorie - er de oorzaak van zouden kunnen zijn dat bijvoorbeeld verrijking van taken niet altijd in dank wordt afgenomen en niet altijd tot een lager verzulim leidt.

\section{Job Characteristics Model}

In de Job Characteristics Theory is er veel meer aendacht voor 
deze behoefte-verschillen tussen mensen. De theorie is ontwikkeld door Hackman en Lawler (1971) en Hackman en 0ldham (1976) en gebaseerd op het werk van Turner en Lawrence (1965). In grote 1ijnen samengevat, komt de theorie op het volgende neer. Uitgegaan wordt van wijf kern-takkkenmerken (de taakvariatie, de mate waarin de taak één geheel vormt, het belang van de taak, de autonomie en de prestatie-feedback die bij de taak hoort). Deze vijf taakkenmerken hebben invloed op drie 'psychologische toestanden', namelijk gevoelens van betekenisvolheid, gevoelens van verantwoordelijkheid, en kennis van resultaten, welke op hun beurt leiden tot motivatie, prestatie, satisfaktie, en weinig verloop en verzuim.

Zoals gezegd, bij dit model wordt er expliclet van uitgegaan dat individuele 'groeibehoefte' optreedt als konditionerende variabele. De relatie tussen de vijf taakvariabelen en de afhankelijke maten is, blijkens empirisch onderzoek, sterker voor werknemers met een zogenaamde grote groeibehoefte dan voor hen met een lage groeibehoefte. Dit geldt ook voor de relatie met verzuim (zie Hackman \& Lawler, 1971; Hackman, Pearce \& Wolfe, 1978; Orpen, 1979). Overigens mag eraan herinnerd worden dat Turner en Lawrence (1965) reeds thet belang van individuele behoeften of oriëntaties als moderator-variabele aantoonden door gebruik te maken van het verschil in normen en waarden tussen stedelingen en plattelanders.

Op basis van het beschikbare empirisch onderzoek kan tenslotte gekonkludeerd worden dat de taakdimensies de motivatie en satisfaktie van werknemers goed voorspellen, maar verzuim minder goed. Dit is begrijpelijk ondat verzuim sterk beïnvloed wordt door gezondheid, persoonskenmerken en andere bedrijfsfaktoren. Alleen onder konstanthouding van deze kenmerken kan de invloed van taakaspekten op verzuim op zijn werkelijke waarde geschat worden. De konditionerende invloed van gezondheld speelt trouwens steeds een rol bij verzuim.

\section{Evaluatie}

Er zijn in deze paragraaf zeven psychologisch getinte organisatietheorieën beschreven die - dat moet voorop gesteld worden niet op de verklaring van verzuim gericht waren, maar waarin verzuim wel als te verklaren variabele was opgenomen.

De volgende konklusies zijn te trekken. De drie beschreven pro- 
cestheorieën kunnen als konkurrerend angemerkt worden. De vraag echter welke van deze drie theorieën (de ruil-, de billijkheidsof de verwachtingstheorie) het best verzuim verklaart is niet te beantwoorden ondat ze niet in konkrete detall-hypothesen uitgewerkt en ten aanzien van verzuim getoetst zijn. Bovendien is er twijfel geuit angaande de theoretische juistheid.

De ruiltheorie vat het verzuim van werknemers op als saldo van input en output of als 'betaalmiddel' ter kompensatie van de te gering geachte opbrengsten, de billijkheidstheorie als 'vluchtmiddel' voor gebrek aan arbeidssatisfaktie, en de verwachtingstheorie als een gevolg van een laag ingeschatte arbeidssatisfaktie, indien men wel op het werk aanwezig is.

In de meer inhoudelijke theorieën - de roltheorie, de leiderschapstheorieën en de taaktheorieën - is verzuim een gevolg van respektievelijk rolproblemen, bepaelde vormen van leiderschapsgedrag en bepaalde taakkenmerken. In tegenstelling tot de procestheorieën kan men de inhoudelijke organisatietheorieën als komplementair kenmerken (verzuim kan namelijk het gevolg zijn van zowel rolproblemen als leiderschapsgedrag als taakkenmerken tegelijkertijd).

In veel theorieën wordt het direkte verband arbeidssatisfaktie verzuim verondersteld. Alleen March en Simon (1958) hebben in hun toepassing van de ruiltheorie aandacht gevraagd voor het feit dat de relatie satisfaktie - verzuim doorkruist wordt door de sankties die er op verzuim staan en door de arbeidsalternatieven. Deze auteurs hebben daarmee voor een deel reeds de beperktheid aangetoond van het begrip satisfaktie voor de verklaring van het ziekteverzuim van werknemers in organisaties. Men kan hier ook nog de doorkruisende werking aen toe voegen van persoonlijke behoeften/oriëntaties en de gezondheidstoestand in de relatie arbeidssatisfaktie - verzuim.

Een laatste opmerking in deze evaluatie betreft het ontbreken van verzuim als variabele in de meer sociologisch getinte organisatietheorieën. Organisatie-sociologen als Woodward, Perrow, Blau en Pugh, Hickson en Child van de Engelse Aston University-groep hebben getracht de struktuurkenmerken vast te leggen waarop organisaties kunnen verschillen, maar hebben weinig aandacht besteed aan de invloed van deze kenmerken op attituden en gedrag van de 
orgenisatieleden. Emplisisch onderzoek waarin nagegaan is wat de invloed is van organisatiestruktuur-kenmerken op verzuim is in beperkte mate wel aanwezig, maar enige theorievorming op dit terrein bestaat niet (met uitzondering van Philipsen, 1969; zie \$ 2.5).

\subsection{Specifiek op verzuim gerichte hypothesen}

Aan het begin van deze paragraaf zij er nagmaals op gewezen dat het verschil tussen eenvoudige en uitgewerkte theorieën als gradueel beschouwd dient te worden. Een eenduidig criterium voor thet maken van het onderscheid tussen $\S 2.4$ en $\S 2.5$ is dan ook niet voorhanden.

In de literatuur worden Hill en Trist (1953) meestal gezien als de eerste auteurs die iets an theorievorming hebben gedaan op het gebied van verzuim. Hun konklusie was dat verzuim(frekwentie) individu- en tijdgebonden was. Dat wil zeggen dat sommige werknemers - ongeacht de afdeling waarin ze werken - veel en andere weinig verzuimen en dat in de carrière van betreffende werknemers het hoogste verzuim voorkomt in het tweede halfjaar van hun diensttijd, terwijl het verzuim in het eerste halfjaar en in latere half jaren geringer is. Hill en Trist leggen dit uit door te wijzen op de aanpassingsproblemen van het individu aan de organisatie. Deze problemen zouden in het tweede halfjaar hun top bereiken en daarna wegebben. De auteurs plaatsen verzuim dus min of meer in een socialisatietheorie.

Vermeld dient te worden dat $H i l l$ en Trist hun kanklusies baseerden op 289 werknemers gedurende hun eerste vier dienstjaren in een Engels staalbedrijf. Interveniërende faktoren konden echter niet onder kontrole gehouden worden, en of het wellicht om een bedrijfswerschi.jnsel ging, kon - door de onderzoeksopzet - ook niet vastgesteld worden.

Ook Lundquist (1958) gebruikte het begrip 'unfavorable job adjustment', ongunstige aanpassing van de werknemer aan zijn arbeldssituatie, als verklaring voor verzuim. Maar ondat hij aanpassing simpelweg operationaliseerde met wragen naar aspekten van arbeidssatisfaktie, kan zijn publikatie op deze plaats verder buiten beschouwing biljven. 
March en Simon (1958) en Knox (1961) waren de eersten die naast verzuin-stimulerende faktoren ook verzuim-beperkende tegenkrachten expliciet in hun theoretische opzet opnamen. De theorie van March en Simon is reeds even aan de orde geweest bij de bespreking van de ruiltheorieën in de vorige paragraaf. Zij gaan ervan uit dat werknemers hun opbrengsten afzetten tegen hun inzet. De balans hiervan bepalt in principe de mate van satisfaktie en de mate van verzuim.

Als verzuimstimulerende bedrijfsomstandigheden noemen March en Simon in concreto: (I) gebrekkige overeenkomst tussen de arbeidssituatie en het zelfbeeld van de werknemer; (2) lage voorspelbaarheid van de instrumentele taakrelaties; (3) weinig overeenkomst tussen de eisen die het werk stelt en de eisen die andere rollen stellen (bijvoorbeeld door arbeidsuren, ploegendienst, die soms de rol van echtgenoot of vader kunnen bemoeilijken). Philipsen (1969) noemde deze omstandigheden faktoren die de kans op instrumentele binding van de werknemer met $z i j n$ werksituatie kunnen vergroten of verkleinen (zie $\S 2.5$ ). In de visie van March en Simon ontstaat door deze faktoren de wens tot (verloop en) verzuim, die al dan niet geëffektueerd wordt naar gelang de tegenkracht van konjunkturele omstandigheden en demografische persoonskenmerken van de betreffende werknemers. Dus een slechte konjunktuur en bepaalde persoonskenmerken kunnen verzuimbeperkend optreden. In het laatste geval bijvoorbeeld bij langere diensttijd of hogere leeftijd (March en Simon gingen ervan uit dat ouderen minder tot verzuim geneigd waren!).

Knox (1961) bestempelde de aanpak van Hill en Trist (1953) als een sociaal-psychologische en die van hemzelf als een sociologische, omdat hij wilde nagaan welke bedrijfsfaktoren tot verzuim leiden. Hij onderscheidt enerzijds prikkels om in dienst te blijven of aanwezig te zijn (zoals een goed loon, goede uitkeringen, aantrekkelijke werkomstanidgheden) en anderzijds barrieres tegen aanwezigheid (zoals slechte gezondheid, problematische gezinsomstandigheden en grote woon - werkafstand) en barrières die aanpassing aan het bedrijf bemoeilijken (zoals jeugdige leeftijd, korte diensttijd en andere kulturele achtergrond). In een empirisch onderzoek in een Argentijnse katoenfabrlek makte Knox met de door hem gebruikte variabelen zijn theoretische uitgangspunten plausibel. 
De begrippen van Knox zijn door As (1962) gebruikt in een verzuimmodel warin (1) prikkels om aanwezig te zijn en het ontbreken van barrlères tegen aanpassing de gevoelens van binding aan het bedrijf bepalen, en (2) barrières tegen aanwezigheid het werkelijke verzuim bepalen. Vanwege de aanwezigheid van verzuim-beperkende en -stimulerende krachten noemt As zijn theorie een 'push-pull-theory'.

Men kan zeggen dat zich hier voor het eerst iets van een enigszins uitgewerkte sociologische of sociaal-psychologische verzuimtheorie begint af te tekenen. Het empirisch onderzoek dat As zelf verrichtte kan echter niet als een toetsing van zijn model aangemerkt worden, omdat hij geen prikkels en barrières operationaliaeerde en in verband bracht met verzuim, maar alleen de relatie tussen de mate van satisfaktie en verzuim onderzocht.

Gibson (1966) vond dat verzuim op drie manieren gekarakteriseerd kan worden: (1) niet aanwezig kunnen zijn door ziekte; (2) niet aanwezig kunnen zijn door externe omstandigheden, buiten individu en organisatie om; (3) niet aanwezig willen zijn. Deze drie karakteristieken hebben enige overeenkomsten met de in $\S 2.5$ te behandelen begrippen verzuimnoodzaak, verzuimgelegenheid en verzuimbehoefte (het niet aanwezig willen zijn noemt Gibson overigens illegitiem, terwijl dat aspekt niet gekoppeld is aan het begrip verzuimbehoefte).

Ook bij Gibson vindt men voor een deel eerder gebruikte begrippen terug. Hij onderscheidt enerzijds het normen- en waardensysteem van het individu en anderzijds het systeem van beloningen en verplichtingen van de orgenisatie. Uit de konfrontatie van beide ontstart de positieve of negatieve identifikatie van het individu met aspekten van de werksituatie en de niet-werksituatie.

Vermeldenswaard is verder dat Gibson naast individu en organisatile ook het begrip ongeving in zijn madel opnam, maar dat niet verder uitwerkte. De relatie tussen individu en organisatie wordt door Gibson gezien als een ruilrelatie en verzuim is in deze visie het gevolg van een zwakke identifikatie met 'aangeboden" werkaspekten of een sterke identifikatie met zaken buiten het werk. Het laatste zou bijvoorbeeld meer het geval zijn bij stedelijk en minder bij plattelandspersoneel.

Identifikatie met aspekten van de werksituatie respektievelijk aspekten buiten de werksituatie is dus het centrale koncept in 
het model van Gibson. Hij heeft zijn ideeën door middel van Indirekte onderzoeksgegevens proberen plausibel te maken, bijvoorbeeld door te wijzen op de positieve relatie bedrijfsgrootte verzuim (in grote bedrijven zou men minder identifikatie met de werksitulatie aantreffen).

Als afsluiting van deze paragraaf kunnen nog eens de belangrijkste konklusies uit de hier aangehaalde publikaties kort sanengevat worden.

- De relatie tussen individu en organisatie wordt zowel door March en Simon (1958) als door Gibson (1966) als een ruilrelatie gezien. Daarentegen leggen $\mathrm{Hill}$ en Trist (1953), Lundquist (1958), Knox (1961) en As (1962) veel meer nadruk op het al dan niet slagen van de aanpassing van het individu an de organisatie (socialisatie).

Een derde wijze warop verzuim opgevat werd, is als vluchtgedrag dat vaak impliciet gehanteerd wordt door auteurs die de relatie satisfaktie - verzuim benadrukken.

- Krachten die het individu tot de organisatie doen antrekken (ook wel 'prikkels" en beloningen genoemd) worden onderscheiden door March en Simon, Knox, Ass en Gibson. Hieronder vallen arbeidssituatie-kenmerken (taakaspekten), werkomstandigheden, loon en uitkeringen.

- Krachten die het individu dwingen om aanwezig te zijn (ook wel verplichtingen genoemd) worden door March en Simon en door Gibson geïntroduceerd. March en Simon rangschikken hier onder meer onder: slechte ekonomische

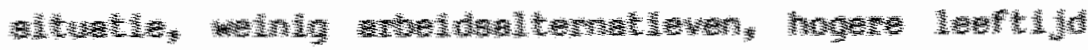

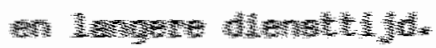

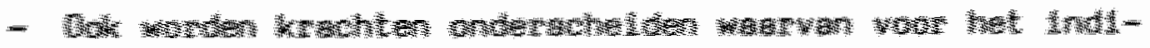

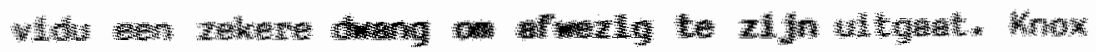

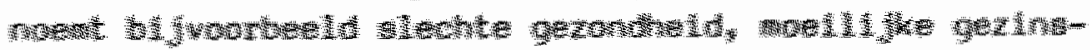
angtandioheder en gwhe won - werkf

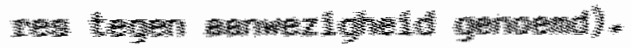

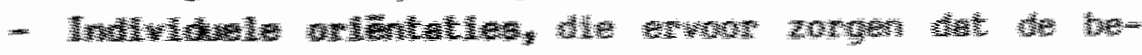

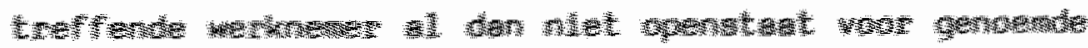

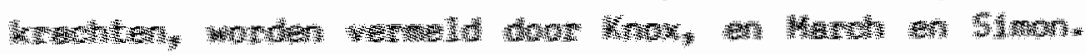

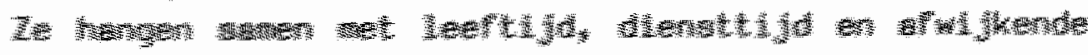

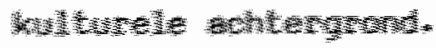

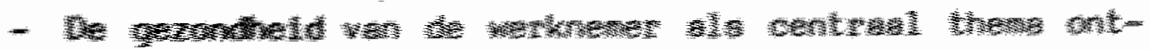


breekt volledig in de hier behendelde sociologische/psychologische deel-theorieën. Alleen knox noemt gezondheid als dwang om afwezig te zijn.

\subsection{Specifiek op verzuim gerichte theorieën}

Een eerste publikatie die voor het Nederlandse taalgebied van grote warde is geweest, is de theoretische beschouwing van $M$. de Groot (1958).

Hij onderscheidt in zijn boek vier - overigens niet erg scherp gedefinieerde - omstandigheden warvan het verzuimgedrag afhankelijk is. Deze kunnen, mede op basis van herformuleringen van Philipsen $\left(1966^{\circ}\right)$, als volgt aangeduid worden:

1. de verzuimbehoefte, waaronder verstaan wordt het complex van gevoelens van lichamelijke en geestelijke aard van de werknemer (onwelbevinden), resulterend in het gevoel van niet in staat te zijn te werken en veroorzaakt door de situatie waarin de werknemer zich bevindt;

2. de verzuimnoodzaak, bepaald door vigerende medische en maatschappelijke opvattingen met betrekking tot het feit of lemand bij een bepaalde aandoening al dan niet ziek en/of arbeidsongeschikt beschouwd moet worden. Philipsen (1969, p. 36) noende dit de subjektieve verzuimnoodzaak. De door hem toegevoegde objektieve verzuimnoodzaak had betrekking op het 'aanbod' van aandoeningen - de hoeveelheid en de ernst - dat zich aan de werknemer voordoet, bijvoorbeeld in de vorm van hinderlijke lichamelijke werkomstandigheden;

3. de verzuingelegenheid, bepaald door het complex van matregelen en usances, die de beslissing van de werkmemer om te verzuimen bij twijfelgevallen in remmende dan wel bevorderende zin kunnen beïnvloeden. Hieronder vallen, volgens De Groot, ziektekontrole en de vereiste wijze van ziekmelding, maar ook de binding aan kollega's en de preventieve aktiviteiten van een medische en/of personeelsdienst;

4. de verzuimmogelijkheid, bepaald door de financiële en sociale konsekwenties van het ziek-zijn voor de werknemer en zijn gezin. Financiële konsekwenties hangen samen met wachtdagen, ziekengelduitkeringen en mogelijk ontslag. Sociale konsekwenties kunnen ruzie met of sankties door de 
baas of de kollega's zijn. Volgens De Groot bepaalt ook de ekonomische konjunktuur in sterke mate de verzuimmogelijkheid.

Verder wees De Groot nog op een andere belangrijke amstandigheid, die vooral de verzuimdur een verlengende impuls kan geven. Dit betreft het zogenaamde iatrogene verzuim, dat wil zeggen het verzuim dat het gevolg is van het handelen van de arts zelf. Hiermee wordt bedoeld de toeneming van het aantal verwijzingen van huisarts naar specialist en ziekenhuis, de daarmee gepaard gaande wachttijden en de betere, maar wel meer tijd nemende diagnasemethodieken. Philipsen (1966b) plaatste deze faktoren onder het theoretische begrip "verzuimgelegenheid" omdat ze de beslissing van de werknemer om nog langer te verzuimen in bevorderende zin kunnen beïnvloeden. Het iatrogene verzuim is overigens door Tordoir et al. (1976) in een empirisch onderzoek onder de loupe genomen, waarbij bleek dat circa twaalf procent van alle verzuimde degen geweten kan worden aan het niet-optimaal funktioneren van de organisatie van de medische hulpverlening.

In zijn proefschrift heeft Philipsen (1969) voortgebouwd op de publikatie van De Groot (1958). Hij heeft, op twee nivo's, aan theorievorming gedaan, namelijk op individueel nivo en op bedrijfs- of makro-sociaal nivo. Men zou ook kunnen zeggen dat hij een sociaal-psychologische en een sociologische verzuimtheorie heeft geformuleerd. Allereerst gaat het om een beslissingsmodel ter verklaring van het verloop van het modale ziekte- respektievelijk verzuimgeval. De fasen die hij hierin onderscheidde zijn: (1) de toestand van welbevinden en het optreden van onwelbevinden; (2) de herkenning van gezondheidsproblemen; (3) de bereidheid hulp en/of genezing te zoeken; (4) de aanvaarding van de rol van patient; (5) de bestendiging gedurende enige tijd van het rolgedrag van patient; (6) de afloop van het ziektegeval.

Voorts stelt Philipsen dat er, afhankelijk van de aerd en de ernst van de aandoening, in elke fase van het proces een bepaalde mate van beslissingsvrijheid is voor de patient.

Belangrijk is, dat in dit model het begin, de duur en het einde van het verzuimgeval opgenomen $z_{i j n}$, waarbij geaksentueerd wordt dat deze momenten gepaard gaan met een bepalde mate van beslissingsvrijheid. Vandaar ook dat in het werk van Philipsen op zo expliciete wijze de frekwentie en de duur van het verzuim onder 
scheiden worden.

Philipsen schat dat onder mannelijke werknemers in de industrie bij ongeveer 75 procent van de ziekmeldingen een aanzienlijke mate van beslissingsvrijheid bestaat dit al dan niet te doen. Aan de andere kant zou bij de rest van de gevallen (de meest ernstige gevallen) juist ten aanzien van de hersteldatum meer sprake zijn van beslissingsvrijheid.

Tenslotte makkt Philipsen de koppeling tussen de individuele beslissingstheorie en de vraag naar de oorzaken van de verschillen in verzuim tussen bedrijven. Verschillen in verzuimfrekwentie tussen bedrijven worden door hem namelijk vooral teruggevoerd op de verschillen in aantallen verzuimmeldingen, warbij juist de beslissingsvrijheid om al dan niet te verzuimen groot is (hij noemt dit de sektor van het 'grijze' verzuim). Deze verschillen tracht hij voornamelijk te verklaren door middel van de begrippen van De Groot, namelijk de verzuimnoodzaak, verzuimbehoefte en verzuimgelegenheid van de werknemer in betreffende bedrijven. Eenzelffe redenering geldt bij de duur van de gevallen. Omdat de begrippen verzuimgelegenheid en verzuimmogelijkheid (respektievelijk de matregelen en de daraan verbonden konsekwenties voor de werknemer) zo nauw met elkaar verbonden zijn, voegde Philipsen (1966a; 1969) deze twee begrippen van De Groot in zijn theoretische opzet samen.

In het meer organisatie-sociologische gedeelte van zijn proefschrift gebruikt Philipsen, naast de begrippen van De Groot, ook een aantal begrippen van March en Simon (1958) en van Lammers (1964) om de verzuimbehoefte en verzuimgelegenheld meer 'body' te geven.

Lammers ging ervan uit dat een organisatie zijn "uiterlijke samenhang' (geindiceerd door bijvoorbeeld personeelsverloop en verzuim) te danken heeft aan zijn bindingskracht, lokmiddelen en dwangmiddelen. Bindingskracht of innerlijke samenhang wordt door Lammers (1964, p. 12) gedefinieerd als "de mate waarin de organisatiegenoten zich met de organisatie als geheel of met deelgroeperingen ervan - , alsmede de mate waarin die deelgroeperingen zich met het organisatie-geheel verbonden voelen". Binding of gevoelens van verbondenheid met een organisatie kunnen volgens Lammers onder meer een instrumentele of sociale grondslag hebben, dus respektievelijk met de taakinhoud of met de medemensen te ma- 
ken hebben. Philipsen nam de begrippen instrumentele en sociale binding en dwangmiddelen op in zijn theorie ter verklaring van de bedrijfsgewijze verschillen in verzuim. Hij redeneerde dat instrumentele en sociale binding de verzuimbehoefte bepalen en dwangmiddelen de verzuimgelegenheid.

Tenslatte nam hij de begrippen stabiele werkverhoudingen, werkbezwaren en kansen op zelfontplooiing van March en Simon (1958) over, ter specificering van de instrumentele binding aan de organisatie.

In zijn theorie voegde hij aan deze begrippen toe: de verzuimnoodzaak, de individuele waardenoriëntaties van de werknemers en de aandacht voor het individuele ziektegeval van de kant van het bedrijf.

In schema 2.1 (zie p. 32/33) zijn alle gebruikte begrippen en variabelen weergegeven. De inhoud van dit schema is gedestilleerd uit de formuleringen van Philipsen (1969, p. 68-83, p. 151-153). In hoofdstuk $5, b_{j} j$ de hypothesen rond de te gebruiken variabelen, wordt erop teruggekomen.

Na de behandeling van het werk van Philipsen wordt nu met een evaluatie ervan besloten. Philipsen's theorie gaat niet in op de onderlinge verbanden van de elementen warruit deze is opgebouwd, zodat men zijn theorie meer een inhoudelijke den een procesmatige theorie zou kunnen noemen. In het eerste geval gaat het om de vraag welke faktoren verzuim beïnvloeden en in het tweede geval. om de vraag op welke manier deze dat doen.

Op heldere wijje heeft hij theoretische begrippen van andere auteurs (met name De Groot, Lammers, March \& Simon) geintegreerd in een in grote mate volledige theorie ter verklaring van verschillen in verzuim tussen bedrijven. Het sukses ervan blijkt ook uit het feit dat hij erin slaagde met zijn negentien varlabelen tussen de 50 en 65 procent van de variantie te verklaren in de drie door hem gebruikte verzuimmaten.

Hoewel hij daar niet naar verwijst, is een aantal van zijn begrippen ook - in andere bewoordingen - terug te vinden in de reeds eerder behandelde publikatie van Knox (1961). De bindingsvariabelen (onder andere lokmiddelen) komen overeen met Knox" begrip 'prikkels on aanwezig te zijn'. De gezondheidsvariabelen die de verzuimnoodzaak indiceren, alsmede de in het kader van de binding opgevoerde werkbezwaren vallen onder Knox' begrip 'barrières 


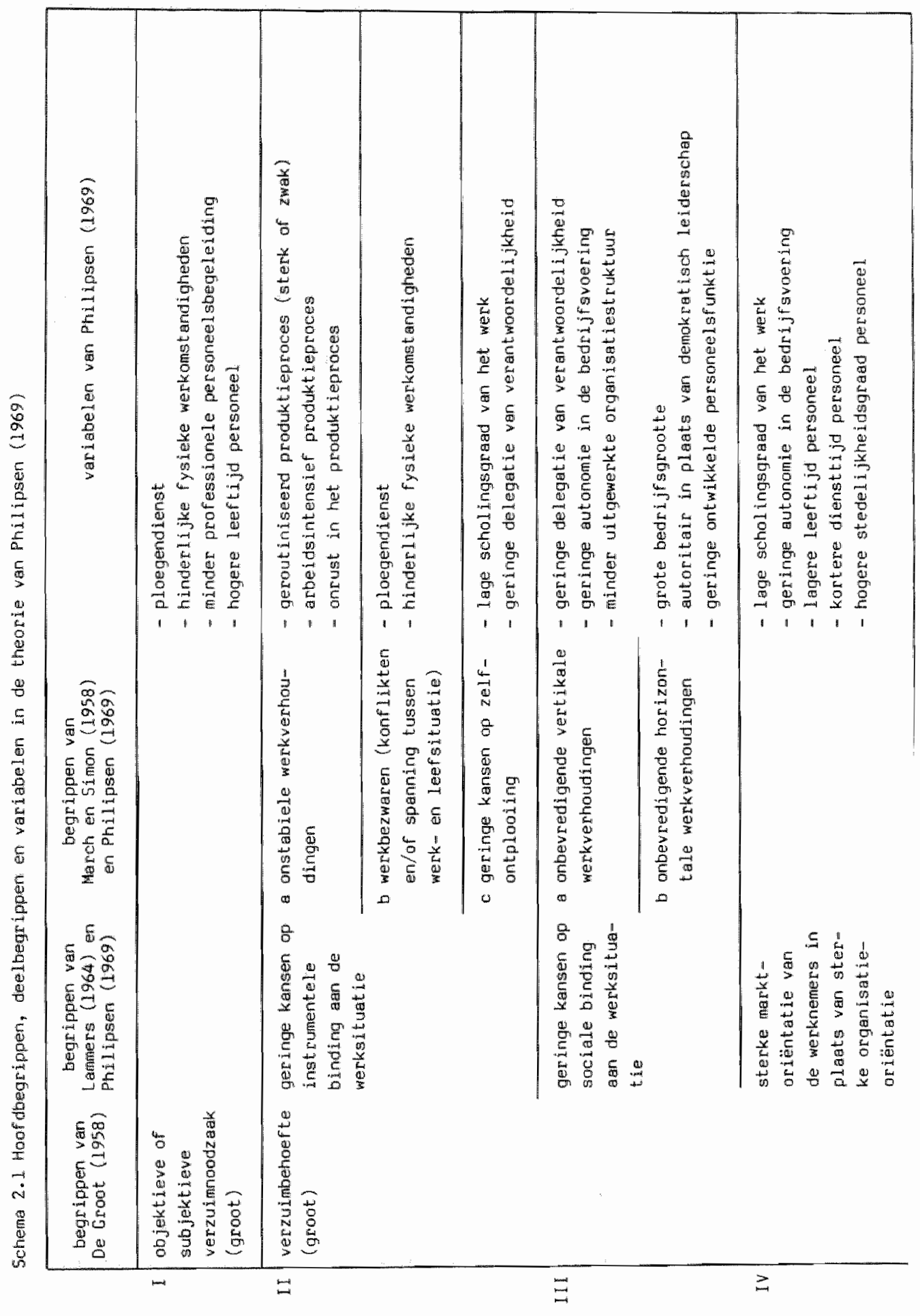




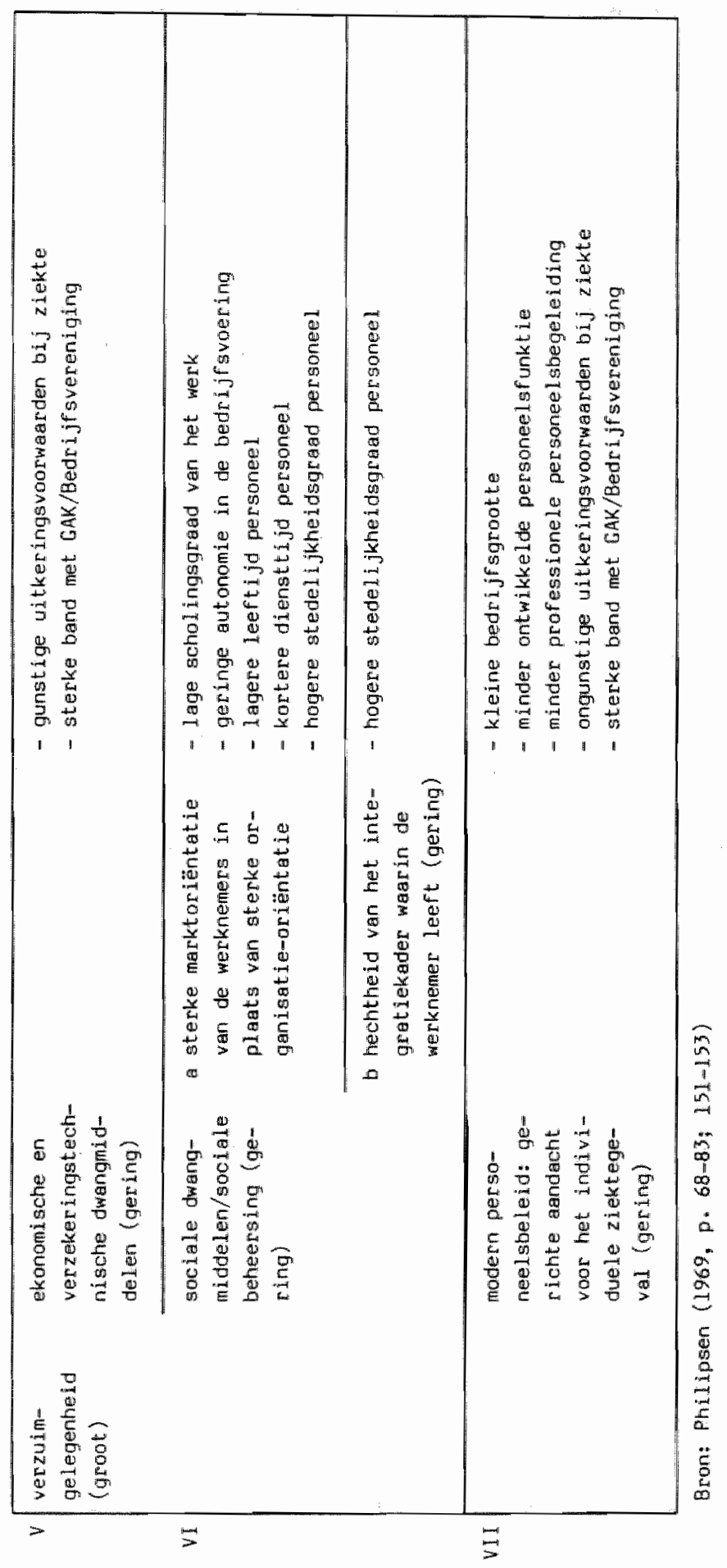


tegen aanwezigheid'. Voorts $1 i j k e n$ individuele waardenoriëntaties overeen te komen met 'barrieres tegen aanpassing aan het bedrijf'. De overeenkomsten met het model van knox tonen nog eens de relevantie van een aantal theoretische begrippen aan.

Tenslotte nog enige opmerkingen over niet in de theorie van Philipsen opgenomen variabelen. Sterk persoonsgebonden variabelen als bijvoorbeeld geslacht, gezinsomstandigheden, woon - werkafstand, salaris, promotiemogelijkheden, soort vrijetijdsbesteding en individuele wardenoriëntaties ten aanzien van gezondheid en vrije tijd, alsmede "makro"-variabelen die in grote lijnen voor de meeste bedrijuen hetzelfde zijn, zoals de struktuur van de gezondheidszorg en het medisch handelen in het algemeen, zij.jn niet in het model opgenomen. De achtergrond hiervan is de gebruikte bedrijfsvergelijkende onderzoeksmethode, waarbij variabelen die wel tussen personen, maar niet tussen bedrijven discrimineren, niet onderzocht kunnen worden. Een aantal van dit soort individugebonden variabelen werd door Philipsen wel benaderd door gebruik van bedrijfsgemiddelden/-indices - zoals de gemiddelde scholingsgraad van het werk, leeftijd, diensttijd en stedelijkheidsgraad van het personeel. De meeste der bovengenoemde, niet in het onderzoek figurerende variabelen zijn echter in principe wel in de theorie op te nemen. Ceslacht, gezinsomstandigheden en woon werkafstand zouden bijvoorbeeld onder werkbezwaren c.q. konflikten tussen werk- en leefsituatie opgenomen kunnen worden; salaris en promotiemogelijkheden onder financiële lokmiddelen, om de binding aan de werksituatie te vergroten, etcetera. Van de duurverlengende gevolgen van bijvoorbeeld wachttijden in de gezondheidszorg (Tordoir et al., 1976) werd door Philipsen zelf (196.6 b) opgemerkt dat deze onder het theoretische begrip 'verzuimgelegenheid" geplaatst zouden kunnen worden.

De konklusie lijkt dus gewettigd dat er geen duidelijke leemten in de theorie anwezig zijn.

Volgens Gadourek (1970) is een minder sterk punt van de theorie dat éénzelfde variabele een indikator kan zijn van méérdere meer abstrakte in de theorie voorkomende begrippen. De variabele scholingsgraad bijvoorbeeld wordt geacht zowel een indikator te zijn van de verzuimbehoefte als van de verzuimgelegenheid, en ploegendienst zowel van verzuimnoodzaak als van verzuimbehoefte, etcetera.

Deze kanttekening is op zichzelf niet onjuist, maar wordt minder 
bezwaarlijk als men bedenkt dat alle in de theorie voorkamende abstrakte begrippen niet door één maar door minstens twee en meestal meer konkrete variabelen worden vertegenwoordigd, zodat de werking van de betreffende koncepten - hoewel niet exact te toetsen - wel plausibel te maken is.

Uit de periode na het verschijnen van de studie van Philipsen zijn nog twee in het Engelse tarlgebied zeer vaak geciteerde bronnen te noemen, die uit theoretisch oogpunt van belang zijn. Het gaat hier om de publikaties van Nicholson (1977) en Steers en Rhodes (1978).

Nicholson meent dat individueel verzuimgedrag op drie verschillende manieren opgevat kan worden (zie ook Chadwick-Jones et al., 1973), namelijk als vluchtgedrag uit de arbeidssituatie; als gevolg van problemen binnen het individu zelf (intern konflikt); en als doelgericht, rationeel gedreg, zools door de ruiltheorie gesteld. $\mathrm{Hij}$ is echter van mening dat de laatste interpretatie verre van de werkelijkheid staat omdat allerlei niet-rationele elementen een rol spelen in verzuimgedrag. Vervolgens formuleert Nicholson een theorie ter verklaring van verzuimfrekwentie; uitdrukkelijk laat hij de duur van het verzuim (de werkhervatting) bulten beschouwing amdat daarop volgens hem weer andere faktoren van invloed zijn. Zijn model is in scheme 2.2 (p. 36) samengevat. Binding aan de organisatie wordt daarin bepaald door persoonskenmerken, werkoriëntaties, zich betrokken voelen bij het werk en de relatie werknemer - bedrijf. Verder bepalt binding dan weer de aanwezigheidsmotivatie en het laatste, onmeetbare begrip de verzuimf rekwentie.

Nicholson acht zijn begrip 'binding" of 'hechting' (attachment) breder dan begrippen als 'identifikatie met' en/of 'zich verbonden voelen met organisatiedoeleinden" (commitment).

Afgezien van kwesties als de precleze definiëring van begrippen, valt het op dat in dit model ook weer individuele oriëntaties, samenhangend met persoonskenmerken, gekonfronteerd worden met kenmerken van het werk en met lok- en dwangmiddelen. Een goede 'fit' leidt tot binding of hechting, respektievelijk aenwezigheidsmotivatie, respektievelijk een lage verzuimfrekwentie.

Een eerste verschil met de theorie van Philipsen is de pleatsing van het begrip binding. Bij Nicholson is binding het resultaat 


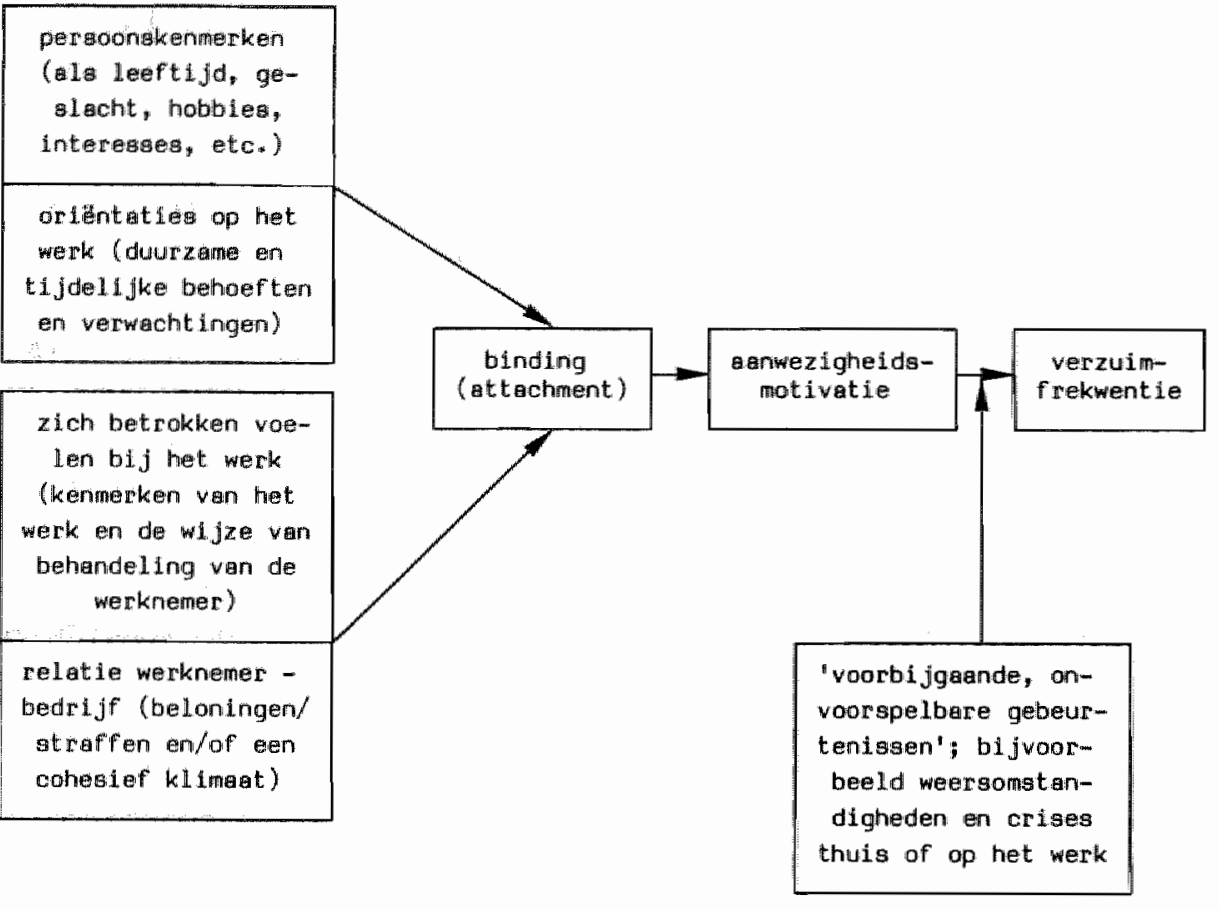

van de konfrontatie van individu met organisatie, en heeft aanwezigheidsmotivatie tot gevolg, terwijl binding bij Philipsen, naast onder andere lok- en dwangmiddelen en individuele oriëntatles, eén van de variabelen is die het verzuim bepaalt. Het model van Nicholson is hierdoor ook iets meer gericht op het proces of het antstaan van het verzuimgeval in stadia en lets minder op welke variabelen verzuim beïnloeden. De konfrontatiegedachte van individu met organisatie troffen we trouwens reeds bij diverse andere auteurs aen.

Ten tweede valt op dat bij Nicholson de aandacht ontbreekt voor de "gezondheidsvariabele" verzuimnoodzaak. Dat laatste kan te maken hebben met het feit dat hij expliciet de verzuimduur buiten zijn model hield en ervan uitging dat de verzuimfrekwentie niet door ziekte en gezondheid bepaald wordt.

Ten derde bestaat er volgens Nicholson een direkte invloed van binding op aanwezigheidsmotivatie, maar wordt de invloed van aan- 
wezigheidsmotivatie op verzuimfrekwentie gekonditioneerd door 'voorbijgaande, onvoorspelbare gebeurtenissen' als weersomstandigheden en crises thuis of op het werk. Opvallend is dat Nicholson juist op deze plaats niet de gezondheidsstoornissen van het individu invoegde. De relatie sterke aanwezlgheidsmotivatie - lage verzuimfrekwentie zou immers doorkruist kunnen worden door de gezondheidstoestand van de betreffende werknemer.

Bij Philipsen komt het begrip aanwezigheidsmotivatie niet voor. Maar als men zijn begrippen goed leest (1969, p. 36), blijkt dat verzuimbehoefte en verzuimgelegenheid samen gelijk te stellen zijn aan (of resulteren in) aanwezigheidsmotivatie. Twee personen met verschillende verzuimbehoefte en/of verschillende verzuingelegenheid zullen zich dus bij dezelfde gezondheidsstoornis (aandoening) ook verschillend gedragen, dat wil zeggen zich niet even snel ziek melden en/of beter melden.

Dat Nicholson de overgang van aenwezigheidsmotivatie naar daadwerkelijk verzuim laat afhangen van voorbijgaande, onvoorspelbare, niet-medische gebeurtenissen is illustratief voor het gebrek aan aandacht voor de medische kant van het verzuim door Angelsaksische psychologen.

Dezelfde kritiek geldt ook voor de publikatie van de Amerikanen Steers en Rhodes (1978). De kern van hun verzuimmodel zit in de kausale vierslag arbeidssituatie $\rightarrow$ arbeidssatisfaktie $\rightarrow$ anwezigheidsmotivatie $\rightarrow$ verzuim, hetgeen in de organisatiepsychologische literatuur een bekende, hoewel eenzijdige, denkwijze is om verzuim mee te verklaren.

Het gehele model van 5 teers en Rhodes is in scheme 2.3 (p. 38) weergegeven. Aan de vermelde vierslag werd de interveniërende variabele "individuele waarden en verwachtingen" toegevoegd voor de relatie arbeidssituatie - arbeidssatisfaktie. Deze individuele oriëntaties werden geacht beïnvloed te worden door persoonskenmerken.

Het model stijgt echter uit boven de bekende satisfaktie - verzuimmodellen door expliciete toevoeging van twee met verzuimgelegenheid en verzuimnoodzaak vergelijkbare begrippen. Ten eerste onderscheiden Steers en Rhodes namelijk het begrip 'pressure to attend", druk on aanwezig te zijn, welke nast de arbeidssatisfaktie de aanwezigheidsmotivatie bepaalt. Ander deze drukmiddelen worden door Steers en Rhodes gerangschikt: ekonomische en markt- 


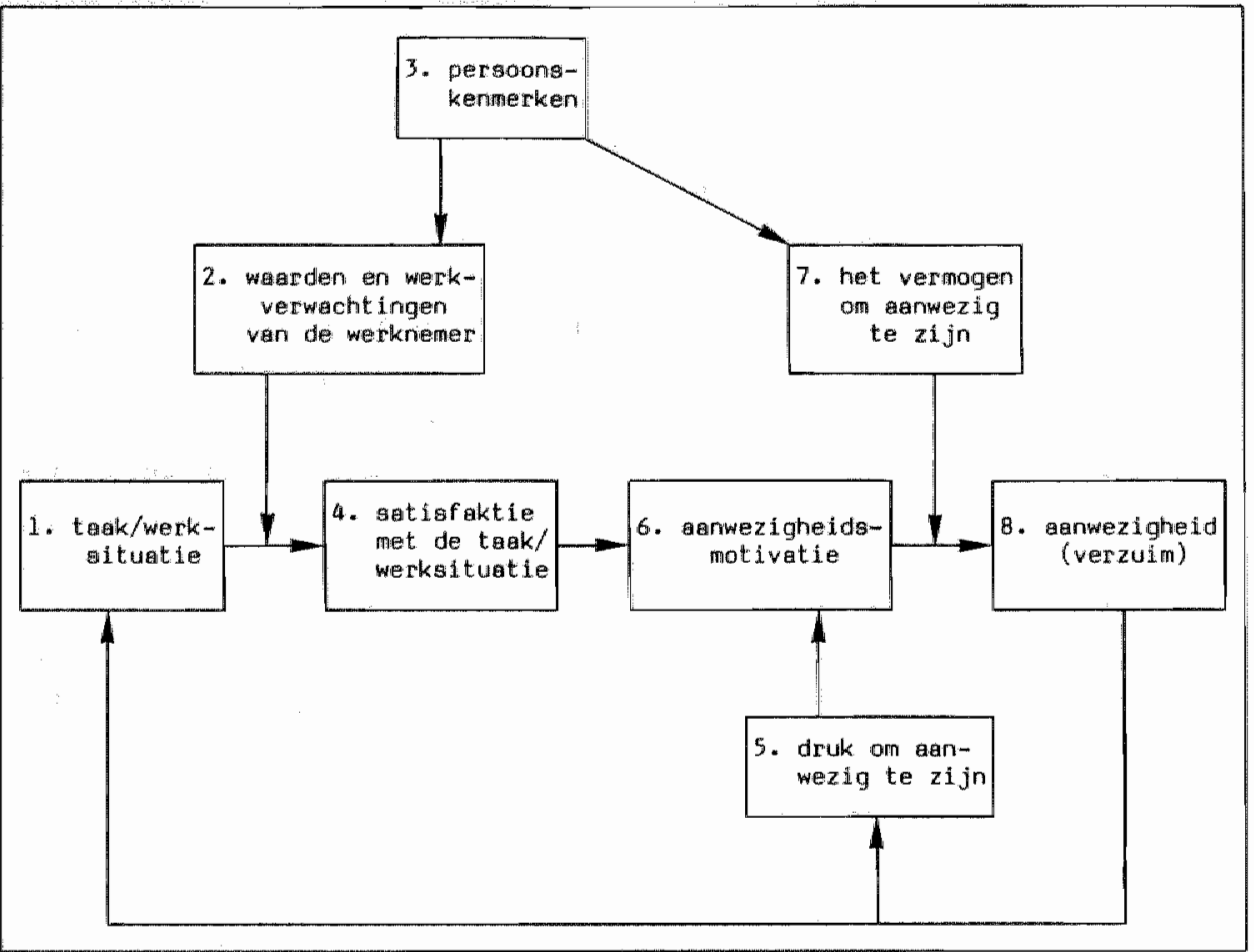

kondities, beloning-/tariefsysteem, werkgroepnormen/cohesie, individuele werkethiek en loyaliteit jegens de organisatiedoeleinden. In termen van Philipsen gaat het hier om ekonomische en sociale lok- en dwangmiddelen (verzuimgelegenheid), alsmede om een sterke organisatie-ariëntatie welke min of meer als een geinternaliseerd dwangmiddel optreedt.

Dok kan men drukmiddelen onderscheiden die juist de afwezigheid in plaats van aanwezigheid bevorderen: slecht weer, ziekte thuis, afhankelijke kinderen en moeilijke woon - werkverbindingen. Deze rangschikken 5teers en Rhodes onder het tweede toegevoegde begrip, namelijk 'ability to attend', letterlijk te vertalen met het vermogen om aanwezig te zijn. Naar inhoud vertoont dit begrip gelijkenis met verzuimnoodzaak, maar is breder opgevat. Steers en Rhodes proberen hieronder namelijk de faktoren te rangschikken die 'onvrijwillig verzuim' bepalen. Zij denken daarbij aan ziekte en ongelukken, gezinsverantwoordelijkheden en transportproblemen 
(zie Knox, 1961). De laatste twee begrippen zou Philipsen waarschijnlijk onder werkbezwaren rangschikken en niet onder verzuimnoodzaak.

Met het citeren van grote hoeveelheden literatuur maken Steers en Rhodes plausibel dat de in hun model opgenomen begrippen en variabelen samenhangen met verzuim.

Een interessant aspekt van het model van Steers en Rhodes is tenslotte dat het cyclische karakter ervan benadrukt wordt. In hun visie kan bijvoorbeeld een hoog verzuimnivo terugslaan op de arbeidssituatie, de promotiemogelijkheden en de druk die er door de organisatie op de werknemers wordt uitgeoefend om aanwezig te zijn (zie schema 2.3).

Veranderingen in de arbeidssituatie, in promotiemogelijkheden en financiële sankties kunnen dus volgens Steers en Rhodes het gevolg zijn van een bepaald verzuimnivo. In empirisch onderzoek zijn ook aanwijzingen te vinden voor de juistheid van deze visie. Pugh et al. (1959) konkluderen bijvoorbeeld op basis van hun onderzoek onder Schots spoorwegpersoneel dat ziekteverzuim een rol speelt in het al dan niet gepromoveerd worden. Verder vond Dijkstra (1977) aanwijzingen voor de mogelijkheid dat het vóróromen van veel langdurig verzuim tot veel kantakten leidt tussen het bedrijf en externe deskundigen. Tenslotte toonde Szilagyi (1980) in een longitudinale studie an dat leiderschap niet alleen invloed heeft op verzuim, maar ook dat de prestaties en het verzuim van ondergeschikten bepaalde vormen van leiderschapsgedrag - met name 'bestraffend' optreden - van hun chefs oproepen.

In evaluatieve zin kan met betrekking tot dit model weer het gebrek aan aandacht voor ziekte en gezondheid gesignaleerd worden (ziekte is bij Steers en Rhades slechts één van de variabelen die het vermogen om aanwezig te zijn bepalen). Voorts is het model. ook alleen gericht op de verklaring van het ontstaan van het verzuim, net als bij Nicholson (1977) en niet op de verklaring van de duur van het verzuim. Het gebrek aan belangstelling voor de duur van verzuim en de herstelmelding hangt warschijnlijk samen met de gebrekkige belangstelling voor ziekte en gezondheid in de Angelsaksische organisatieliteratuur. Het feit dat in de Angelsaksische landen langdurig verzuim meestal voor rekening van de werknemer zelf komt en buiten 'het gezichtsveld' van het bedrijf raakt, zal hier wel iets mee te maken hebben. Begeleiding van of 
aandacht voor zieke werknemers vindt men in deze onderzoeksliteratuur den ook zelden of nooit als toplc terug. Zie voor een bespreking van deze problematiek: Smulders (1980).

Aan de andere kant kan het model van Steers en Rhodes als veelomvattend en inzichtelijk worden gekenmerkt. Ook het procesmatige en het cyclische karakter van het model zijn sterke kanten. Deze twee aspekten verschaffen een extra inzicht in de verschillende determinanten die het ontstaan van het verzuim beïnloeden, alsmede in de effekten van verzuim op individu en organisatie.

De volgende vijf punten vatten deze paragraaf samen.

(1) De theorieën van de medicus De Groot, de socioloog Philipsen en de psychologen Nicholson en Steers en Rhodes vertonen een zekere mate van convergentie. Als het model van Philipsen (warin de theoretische begrippen van De Groot opgenomen $z i j n)$ vergeleken wordt met de Angelsaksische modellen, blijkt dat de begrippen binding of arbeidssatisfaktie, lokmiddelen, dwangmiddelen, persoonskenmerken en individuele wardenoriëntaties in een of andere vorm steeds aanwezig zijn. Soms staan deze begrippen simpelweg naast elkaar, soms is er een zekere kausale ordening tussen aangebracht.

(2) Philipsen is de enige die organisatie-sociologische begrippen (bijvoorbeeld organisatiestruktuur) in het verklarend model opneemt.

(3) Het begrip gezondheidstoestand echter, dat in Nederlands denken over verzuim een centrale plaats inneemt, komt in de Angelsaksische publikaties niet voor of wordt opgevoerd als één van de vele verzuim-beïnvloedende variabelen. Hiermee samenhangend, valt het op dat de Angelsaksische literatuur weinig of geen aandacht besteedt aan langdurig verzuim en/ of aan de verzuimduur van de gevallen in het algemeen en derhalve ook niet aan duurverlengende faktoren als de organisatie van de gezondheidszorg en de begeleiding van individuele werknemers en/of langdurig zieken. De organisatie van de sociale zekerheid in de diverse landen zal hiervan de voornaanste reden $z i j n$.

(4) Verder speelt de thuissituatie bij Philipsen een ondergeschikte rol (namelijk alleen in het konflikt tussen werken thuissituatie), bij Nicholson kan deze voor 'voorbij- 
gaende, onvoorspelbare gebeurtenissen' zorgen die interveniëren in de relatie aanwezigheidsmotivatie - verzuim, en bij Steers en Rhodes valt de thuissituatie onder het koncept "vermogen om aanwezig te zijn", hetgeen vergelijkbaar is met de opvatting van Philipsen.

(5) Tenslotte wordt het cyclisch karakter van verzuim (dat will zeggen verzuim beïnloedt de werksituatie en de druk om aanwezig te zijn en vice versa) alleen door Steers en Rhodes benadrukt. Andere auteurs hebben nooit aandacht besteed aan dit aspekt, hoewel er aanwijzingen zijn dat deze theoretische gedachte ondersteuning vindt in de empirie.

\subsection{Samenvatting van hoofdstuk 2}

In $\S 2.2$ werd een aantal begrippen behandeld die de relatie werknemer - organisatie omschrijven. Arbeidssatisfaktie, involvering, motivatie, zijn een paar van deze begrippen. Ze worden veelal gepresenteerd als voorspellers van verzuim, hetgeen door empirisch onderzoek in grote lijnen bevestigd wordt, hoewel de relaties soms zwak zijn. Dit laatste heeft als oorzaak dat vele andere begrippen - naast bedoelde relatiebegrippen - invloed hebben op verzuim, hetzij in additieve, hetzij in interveniërende vorm. Bovendien hebben bedoelde relatiebegrippen het nadeel dat niet duidelijk is in welke mate ze persoons- dan wel bedrijfsgebonden zijn.

In de later behandelde theorieën over verzuim komen deze begrippen, die de relatie individu - organisatie indiceren, weer terug. Ze hebben hun waarde voor het inzicht in de verzuimproblematiek en kunnen daar zelfs een centrale rol in spelen, maar dienen niet als enige verklaring opgevoerd te worden.

In $\$ 2.3$ kwamen drie meer procesgerichte theorieën over gedrag in organisaties (ruil-, billijkheids- en verwachtingstheorieën) en drie meer inhoudelijke theorieën (rol-, leiderschaps- en taaktheorieën) aan de orde.

De drie meer inhoudelijke theorieën kunnen als komplementair betiteld worden. Rolproblemen, leiderschapswormen en taakinhouden blijken ook in latere, meer uitgewerkte, theorieën rond verzuim terug te komen. 
Anders is het gesteld met de drie psychologische, meer procesgerichte organisatiegedrag-theorieën, die als konkurrerend beschouwd kunnen worden.

De kritiek op de ruiltheorie en de verwachtingstheorie was dat deze verklaringswijzen uitgaan van zeer rationeel denkende werknemers, die regelmatig en bewust inspanningen en opbrengsten of alternatieve opbrengsten tegen elkaar afwegen.

De belangrijkste vraag, namelijk welke van de drie procestheorieen verzuim het beste kan verklaren, is helaas niet te beantwoorden omdat daartoe onvoldoende empirisch onderzoek beschikbaar is. In het licht van latere verzuimtheorieën zal blijken dat deze psychologische theorieën alle drie op zich in ieder geval onvoldoende verklaring bieden vaor verzulingedrag. Dit heeft te maken met het feit dat in deze theorieën steeds de relatie arbeidssatisfaktie - verzuim als centraal thema voorkomt, maar dat veruit het merendeel van de auteurs de interveniërende en additieve variabelen die bij deze relatie verder van invloed zijn, buiten beschouwing hebben gelaten.

In $\S 2.4$ werd een aantal vroege, weinig-uitgewerkte verzuimtheorieën besproken. Gekonkludeerd werd dat daarin, naast krachten die het individu tot de organisatie doen aantrekken of afstoten, ook krachten onderscheiden worden die het individu dwingen om aanwezig of juist dwingen om afwezig te zijn. De duidelijke konfrontatie tussen individu en organisatie (in een ruilrelatie of een aanpassingsrelatie) vormt van deze en latere publikaties het uitgangspunt. In deze eenvoudige verzuimtheorieën ontbreekt het begrip gezondheld als belangrijk thema nog bijne volledig.

In $\oint 2.5$ kwam een viertal meer uitgewerkte, op verzuim gerichte theorieen aan de orde. Gekonkludeerd werd daarbij dat een zekere mate van convergentie in de theorievorming waar te nemen is. Dit heeft voornamelijk betrekking op het centrale thema satisfaktie en/of binding en op de opname van koncepten als lak-en dwangmiddelen, persoonskenmerken en individuele wardenoriëntaties.

Verder valt op dat, evenals in de eenvoudige theorieën uit de jaren 50 en 60, het begrip gezondheid van de werknemer en de daarop van invloed zijnde faktoren, evenals de effekten ervan op de verzuimduur, in de Angelsaksische modellen sterk verwarloosd of zelfs genegeerd wordt. 
Ook blijkt voor de invloed van de thuissituatie of de niet-werksituatie op het verzuim van werknemers wel enige, maar nog beperkte interesse te bestaan. Overeenstemming over hoe deze invloed opgenomen moet worden in een verzuimtheorie is er niet. Tenslotte lijkt het voor de theorievorming waardevol an de "terugkoppelingslus' in het verzuim aandacht te schenken. Er zijn namelijk aanwijzingen dat verzuim zelf ook als onafhankelijke variabele kan optreden ten opzichte van bijvoorbeeld de arbeidssituatie. 


\subsection{Repliketie-onderzoek}

Zoals reeds in hoofdstuk 1 vermeld werd, is het replikatle-karakter een hoofdkenmerk van deze studie. Achtergrond hilervan was de gedachte dat het verkrijgen van valide kennis van de sociale werkelijkheid vaak meer gediend is met herhaling van veelbelovend eerder uitgevoerd onderzoek, in overigens in ruimte of tijd verschillende onstandigheden, dan met het najagen van geheel nieuwe theoretische inzichten en methodische uitgangspunten.

In een verslag over hun ervaringen met de replikatie van het in 1924/25 uitgevoerde onderzoek over het reilen en zeilen van de gemeente Middletown benadrukken Bahr et al. (1983) de waarde van de replikatie-aanpak. In dit verband spreken zij zelfs van een zekere 'misplaatste neiging tot originaliteit en creativiteit' (p. 261) in de onderzoekspraktijk an Amerikaanse universiteiten. Ze menen dat ze daar zelf ook niet geheel vrij van zijn geweest door, achteraf gezien, toch nog te veel te hebben willen veranderen in de oorspronkelijke onderzoeksopzet.

Een uitvoerige behandeling van replikatie-onderzoek is onder andere te vinden bij Galtung (1967) en bovenvermelde Bahr et al. (1983). Tellingen van de laatsten laten zien dat replikatie meer in de psychologie dan in de sociologie wordt toegepast. De essentie van replikatie is uiteraard (gehele of gedeeltelijke) herha1 ing van eerder uitgevoerd onderzoek. De overeenkomst of het verschil. tussen het eerdere en latere onderzoek kan gelegen zijn in aspekten als de analyse-eenheden, de methode, de inhoud en waarden van de variabelen (Galtung, 1967). Bahr et al. spreken in dit verband ook nog over verschillen in tijd en plaats. In de "ideale' replikatie wordt getracht zoveel mogelijk aspekten gelijk te houden. Als maar weinig aspekten gelijk worden gehouden, wordt het natuurlijk moelijjker de gevonden verschillen tussen eerder en later onderzoek te verklaren. Iets dergelijks vermeldt Lammers (1983, p. 221-222) bij zijn behandeling van semi-replikaties van de kontingentietheorie. Hij komt tot de konklusie dat het "... achteraf nooit met enige zekerheid vast te stellen is of - en zo ja, in hoeverre - uiteenlopende uitkomsten van twee slechts ten dele vergelijkbare onderzoekingen een gevolg zijn (van verschil 
in onderzoeksopzet en/of verschil in onderzochte objekten of in de omstandigheden warin deze verkeren)". Uit de onderzoeksliteratuur kan gekonkludeerd worden dat expliciete, zo volledig mogeIIjke replikatiestudies maar weinig uitgevoerd zijn.

In deze studie zal het onderzoek van Philipsen (1969) uit 1964/65 naar de oorzaken van bedrijfsgewijze verschillen in ziekteverzuim in 1980/81 zo volledig mogelijk gerepliceerd worden. In dit hoofdstuk en in paragraaf 5.3 zal getracht worden duidelijk te maken dat de replikatie op de aspekten onderzoekseenheid, plaats, methode en variabelen redelijk tot goed geslaagd genoemd mag worden. Daarmee is de replikatie voornamelijk een tijdvergelijkende replikatie.

De studie zal echter niet tot een replikatie beperkt blijven. Een dertiental nieuwe variabelen $z a l$ namelijk ontwikkeld en geanalyseerd worden. Wel zal deze uitbreiding duidelijk apart gehouden worden van de eigenlijke replikatie. De analyses worden ook gescheiden behandeld in respektievelijk de hoofdstukken 6 en 7 . In dit hoofdstuk zal nu eerst de onderzoeksopzet van het onderzoek uit 1980/81 beschreven worden. Dok zal aangegeven worden hoe de verhouding is tussen de bedrijven uit 1964/65 en 1980/81 wat betreft bedrijfsgroep en regio/provincie.

\subsection{De onderzochte bedrijven in 1964/65 en 1980/81}

De bedoeling van dit onderzoek was een onderzoeksopzet te hanteren die zoveel mogelijk overeenkwam met die van Philipsen (1969). Hij beperkte zijn bedr1jfssteekproef tot bedrijven die (a) meededen aan de NIPG/INO-verzuimstatistiek, (b) tot de produktiesektor behoorden, (c) uit merendeels mannelijk produktilepersoneel bestonden, en (d) circa 100 tot 400 mannelijke produktiepersoneelsleden in dienst hadden. De verzuimcijfers hadden ook betrekking op het mannelijke produktiepersoneel.

Philipsen beargumenteerde deze onderzoeksopzet door erop te wijzen dat in een onderzoek warin organisatiekenmerken centraal staan de werking van makro-sociologische kategorieën (als produktie- versus administratief personeel en mannelijk versus vrouwelijk personeel) zoveel mogelijk uitgesloten dient te worden. Bovendien is het percentage vrouwelijk personeel in de bedrijven nogal verschillend, zodat eliminatie van deze personeelakategorie 
de zuiverheld van de vergelijking tussen de bedrijven alleen maar ten goede komt. De grootte-inperking had vooral praktische redenen: heel grote bedrijven kennen vaak zeer diverse produktieprocessen, waardoor beschrijuing daarven door middel van één cijfer per bedrijf niet meer valide is. Dus bedrijven die niet aan de NIPG/TNG-verzuimstatistiek meededen, niet-produktiebedrijven (zoals bijvoorbeeld banken en grootwinkelbedrijven), bedrijven met merendeels vrouwelijk personeel (de levensmiddelen- en textielsektor vooral), en bedrijven met een mannelijk produktiepersoneelsbestand van kleiner dan 100 en groter dan 400 werknemers werden daor Philipsen uitgesloten.

In dit onderzoek zijn Philipaen's steekproefcriteria gevolgd, met dien verstande dat het vierde criterium wat soepeler werd gehanteerd. Dit betekent dat bedrijven met circa 50 tot 830 mannelijke produktiepersoneelsleden uiteindelijk tot de steekproef werden toegelaten. Om precies te zijn werden zes bedrijven opgenomen met een mannelijk produktiepersoneelsbestand van minder dan 100 werknemers en acht bedrijven met een mannelijk produktiepersoneelsbestand van meer dan 500 werknemers.

Verder werd er in dit onderzoek eveneens gestreefd naar 80 à 90 bedrijven die wat betreft bedrijfstak en regio op ongeveer dezelfde wijze verspreid zouden zijn als dat bij Philipsen het geval was.

Wat betreft het in deze studie te hanteren begrip 'bedrijf' kan nog opgemerkt worden dat dit ook het begrip 'vestiging' omvat. In de uiteindelijke onderzoekssteekproef komen bijvoorbeeld verscheidene, geografisch verspreide, vestigingen van ondernemingen of concerns voor. De leidinggevende struktuur en de juridische basis van de participerende 'bedrijven' kunnen dan ook sterk uiteenlopen. Alle deelnemende bedrijven hebben echter een direktie die geheel of gedeeltelijk verantwoordelijk is voor de dagelijkse gang van zaken met betrekking tot de produktie en het personeelsbeheer.

Tabel 3.1 last in de meest linker kolom zien dat er in 1991235 produktiebedrijven (op vrijwillige basis) aan de NIPG/TND-verzuimstatistiek meededen. De niet-produktiebedrijven (gemeentebedrijven, vervoersbedrijven, grootwinkelbedrijven, banken en ziekenhuizen) zijn daer dus niet in opgenomen. Dok vallen de bedrijven die slechts met een deel van hun personeelsbestand aan de 


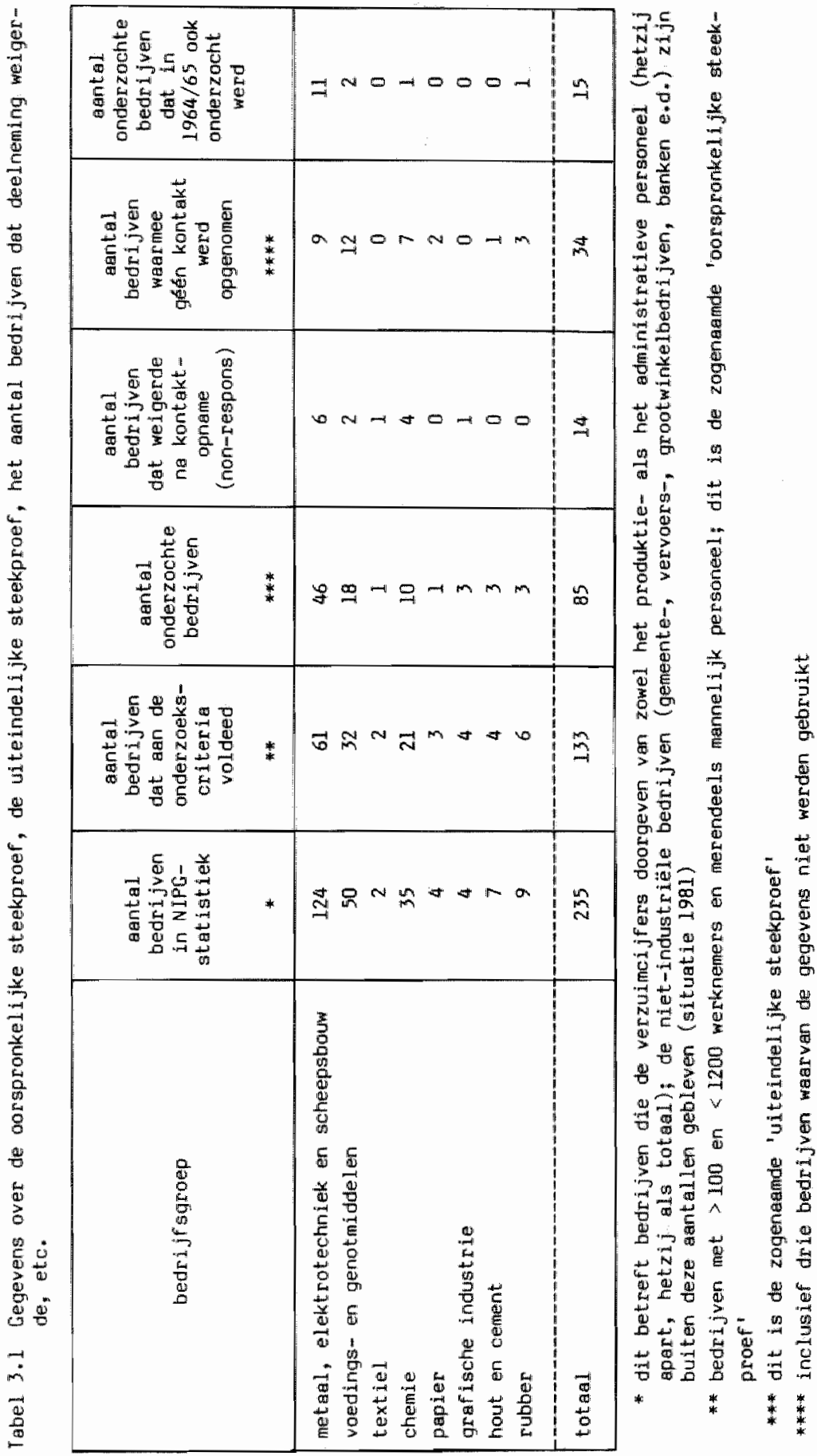


statistiek meededen, buiten deze kategorie van 235.

Vervolgens werden uit deze groep van 235 , die bedrijuen geëlimineerd die een totale personeelsomvang van kleiner den 100 of groter dan circe 1200 werknemers hadden (de bovengrens werd dus iets hoger gelegd dan de grens van 1000 werknemers die Philipsen hanteerde). Twee bedrijven die boven deze grens van 1200 werknemers lagen werden eveneens opgenomen, omdat daarvan bekend was dat het totale produktiepersoneelsbestand nog niet de helft van het totale bestand uitmaakte. Tenslotte werden ook de bedrijven met merendeels vrouwelijk personeel, zoals dat vaak in de textiel- en levensmiddelenindustrie voorkomt, geëlimineerd.

Door deze inperkingen blewen er 133 bedrijven over (zie de tweede kolom van tabel 3.1), die aan de gestelde steekproefcriteria voldeden. Dit is de zogenaande oorspronkelijke steekproef. Van deze 133 bedrijuen kwamen er tenslotte 85 in de zogenaamde uiteindelijke steekproef terecht (zie de derde kolom van tabel 3.1). Bij deze 85 bedrijuen werkte $70 \%$ van het personeel in de produktie, en darrvan was $88 \%$ van het mannelijk en $12 \%$ van het vrouwelijk geslacht.

Van de andere 48 bedrijven die in principe ook voor onderzoek in aanmerking kwamen, werd met 31 geen kontakt opgenomen (omdat het beoogde aantal van circa 85 was bereikt). Voorts werden van drie bedrijven de gegevens niet gebruikt. Dit geschiedde in twee gevallen vanwege onvolledigheid van gegevens en in één geval omdat het bedrijf wat betreft de personeelsomvang ver boven de bovengrens bleek te zitten.

De overige veertien bedrijven waren niet bereid aan het onderzoek mee te doen. De verdeling van de bedrijven die medewerking weigerden en van de niet-participerende bedrijven over de bedrijfsgroepen valt uit tabel 3.1 (vierde en vijfde kolom) af te lezen. De redenen voor weigering waren de volgende:

(a) verwikkeld in een herstruktureringsproces, afs lanking of organisatie-verandering

(b) zelf bezig met onderzoek en/of aktie met betrekking tot verzuim

(c) geen tijd en/of belangstelling (zonder nadere toelichting) 
Deze veertien bedrijven hadden gemiddeld een verzuimpercentage van 10.7 procent (en een gemiddelde frekwentie van 2.00 meldingen per persoon per jaar en een gemiddelde duur per geval van 19.5 kalenderdagen). Deze cijfers zijn iets lager dan die van de in de uiteindelijke steekproef opgenomen bedrijven, doch het verschil is gering (vergelijk met de gemiddelde verzuimcijfers van de 85 bedrijuen, tabel 5.18, p. 145).

Twee zaken betreffende de uiteindelijke steekproef van 85 bedrijven dienen in deze paragraaf nog aan de orde te komen. Het gaat om (a) de representativiteit van de huidige steekproef naar bedrijfsgroep en regio, en (b) de vergelijking van de huidige steekproef met die van Philipsen uit 1964/65.

Wat betreft de kwestie van de representativiteit, kan hier herhaald worden wat Philipsen (1969, p. 94) hierover opmerkte, namelijk dat het in onderzoek warin bedrijven als analyse-eenheid gehanteerd worden, door allerlei praktische beperkingen die men zich moet opleggen bij de selektie van deze bedrijven, bij voorbaat reeds moeilijk is om de bij het universum behorende steekproef samen te stellen.

Daarom moet men in dit soort bedrijfsvergelijkend onderzoek niet streven naar het beschrijven van hèt ziekteverzuim van dè Nederlandse produktiebedrijven met een bepaalde bedrijfsgrootte, maar meer naar het vaststellen en verklaren van relaties tussen beparlde variabelen. Door het verklarend in plaats ven het beschrijvend karakter van het onderzoek voorop te stellen, is de representativiteit van de steekproef van secundair belang en is voldoende variatie/diversiteit in de te onderzoeken bedrijven van primair belang. Voor theorievorming op basis van verklarend onderzoek is overigens wel een zo groot mogelijke reikwijdte van de konklusies gewenst. Dit betekent dat gestreefd moet worden naar een zo onbevooroordeeld mogeli.jk samengestelde steekproef van bedrijuen met grate diversiteit. De cljfers in de tabelien 3.2 en 3.3 moeten dan ook alleen gezien worden als illustratie van de diversiteit en niet on de representativiteit van de steekproef aan te tonen.

In tabel 3.2 wordt de verdeling van de 85 onderzochte bedrijven per bedrijfisgroep afgezet tegen de landelijke verdeling van ondernemingen in dezelfde bedrijfsgroepen per $\mathbb{l}$ januari 1981. Hierbij dient aengetekend te worden dat in het door het CBS gebruikte 
begrip 'onderneming' in de regel de eventueel voorkomende vestigingen te zamen genomen zijn. Dus een hoofdkantoor en drie geografisch verspreide produktiebedrijuen worden in de CBS-gegevens meestal als én onderneming opgevoerd. Omdat het hier echter om bedrijfsgroep-vergelijkingen gat zal deze vertekening niet al te veel invloed hebben.

Te zien valt nu dat in de onderzoekssteekproef de bedrijven uit de metaal, elektrotechniek en scheepsbouw oververtegenwoordigd zijn en die uit de sektoren textiel, papier, grafische industrie en hout en cement enigszins ondervertegenwoordigd. Overigens valt uit tabel 3.2 ook af te lezen dat $6.4 \%(=85 \times 1.00: 1334)$ van alle Nederlandse industriële bedrijven in betreffende grootteklasse in de onderzoekssteekproef vertegenwoordigd zijn.

Uit tabel 3.3 blijkt dat de spreiding van de onderzochte bedrijven in 1980/81 over de elf provincies veel lijkt op de spreiding die landelijk wordt aangetroffen in die tijd. Er is wel enige oververtegenwoordiging van bedrijven uit West-Nederland en een lichte ondervertegenwoordiging van bedrijven uit Oost- en ZuidNederland.

Tabell 3.2 De spreiding van de anderzachte bedrijven over de bedrijfsgroepen in vergelijking met de landelijke cijfers

\begin{tabular}{|c|c|c|}
\hline bedrljfsgraep & $\begin{array}{l}\text { anderzochte bedrijuen } \\
\text { in } \% \text { van total }\end{array}$ & $\begin{array}{c}\text { landelijk } \\
\text { in }{ }^{*} \text { van tataal } \\
*\end{array}$ \\
\hline metari, elektrotechniek en scheepsbouw & 54 & 40 \\
\hline voedtngs - en genotiniddelen & 21 & 19 \\
\hline rextiel & 1 & 5 \\
\hline ohem le & 11 & 9 \\
\hline prapler & 1 & 5 \\
\hline grafigche industrie & 4 & 10 \\
\hline hout en cement & 4 & 8 \\
\hline rubber & 4 & 4 \\
\hline toteal & $\begin{array}{l}100 \% \\
(n=85)\end{array}$ & $\begin{array}{c}100^{60} \\
(n=1334)\end{array}$ \\
\hline
\end{tabular}

* dik betraft alle Nederlandse industriële ondernemingen in betreffende bedrijfsgroepen met een personeelsomvang van 100 of mees personen; situatile per 1 januari 1981

Bron: bewerking wan ongepubliceerd materiaal wan het CBS 
Tabel 3.3 De spreiding van de onderzochte bedrijven over de provincles in vergelijking met de landelijke cljfers

\begin{tabular}{|c|c|c|}
\hline provincie & $\begin{array}{c}\text { onderzochte bedrijuen } \\
\text { in } \$ \text { van totaal }\end{array}$ & $\begin{array}{c}\text { landel } \mathbb{L}_{\mathrm{j}}^{\mathrm{j} k} \\
\text { In } \\
\text { * van totar }\end{array}$ \\
\hline Groningen & 4 & 4 \\
\hline Friesland & 4 & 4 \\
\hline Drenthe & - & 2 \\
\hline Overijssel & 6 & 9 \\
\hline Celderland & 16 & 13 \\
\hline Ut recht & 12 & 7 \\
\hline Noord-Holland & 15 & 15 \\
\hline Zuid-Holland & 22 & 21 \\
\hline Zeeland & 2 & 2 \\
\hline Noord-Brabant & 15 & 17 \\
\hline Limburg & 4 & 8 \\
\hline totaal & $\begin{array}{c}10080 \\
(n=85)\end{array}$ & $\begin{array}{c}100 \% \\
(n=17127)\end{array}$ \\
\hline
\end{tabular}

* dit betreft alle Nederlandse industriële ondernemingen (inalusief delfotoffenwinning) met een persaneelsomvang van 100 of meer personen; situatie per februari 1977

Bron: bewerking van angepubliceerd materiaal van het CBS

Tenslotte kan nog nagegaan worden hoe de steekproef uit 1980/81 $z$ ich verhoudt tot die uit 1964/65. Hierbij moet voorop gesteld worden dat beide steekproeven getrokken zijn uit een, in de tijd verschillende, maar in principe wel zelfde populatie, namelijk uit de produktiebedrijven die - in beide perioden - meededen aan de NIPG/TNO-verzuimstatistiek, met de in het begin van deze paragraaf vermelde additionele kenmerken. Bij de ateekproeftrekking is dezelfde steekproefprocedure toegepest. Dit is belangrijk uit replikatie-oogpunt. Of beide steekproeven met betrekking tot bedrijfstak- en regioverdeling geheel identiek zijn is uit repliketie-oogpunt van ondergeschikt belang.

Welnu, uit tabel 3.4 en 3.5 valt of te lezen dat beide steekproeven elkaar redelijk dekken. Alleen kan men zeggen dat in 1980/81 minder textielbedrijven en meer bedrijven uit de sektoren voedings- en genotmiddelen en hout en cement voorkomen. Bovendien valt te zien dat er in 1980/81 iets minder westelijke en iets meer noordelijke en zuidelijke bedrijwen aanwezig zijn (tabel 3.5). 
Tabel 3.4. De apreiding yar de anderzochte bedrljwen over de bedrijfsgraepen (werge11.jiking onderzoek $1964 / 65$ met $1980 / 81$ )

\begin{tabular}{|c|c|c|}
\hline bedrijfogroep & $1964 / 65$ & $1980 / 81$ \\
\hline $\begin{array}{l}\text { metal, elekt rotechilek en scheepsbouw } \\
\text { woedinge- en genotmiddelen } \\
\text { text lel } \\
\text { chemie } \\
\text { papler } \\
\text { graf lsche industrile } \\
\text { hout en cement } \\
\text { rubber }\end{array}$ & $\begin{array}{r}47 \\
12 \\
9 \\
9 \\
2 \\
3 \\
- \\
1\end{array}$ & $\begin{array}{r}46 \\
18 \\
1 \\
10 \\
1 \\
3 \\
3 \\
3\end{array}$ \\
\hline totael & 83 & 85 \\
\hline
\end{tabular}

* zie Philipsen $(1969, p .250)$

Iabel 3.5 De spreiding van de anderzochte bedrijven over regio's (vergelijking onderzoek $1964 / 65$ met $1980 / 81$ )

\begin{tabular}{|l|c|c|}
\hline \multicolumn{1}{|c|}{ regio } & $1964 / 65$ & $1980 / 81$ \\
\hline Groningen, Friesland, Drenthe & $*$ & 6 \\
Oweri jssel, Gelderland & 3 & 19 \\
Utrecht, Noord-Holland, Zuid-Holland & 19 & 42 \\
Zeeland, Noord-Brabent, Limburg & 49 & 18 \\
\hline total & 12 & 85 \\
\hline
\end{tabular}

* zie Philipsen (1969, p. 249)

Verder kan nog vermeld worden dat vijftien bedrijven die in 1964/ 65 aan het onderzoek van Philipsen meededen, ook aan het huidige onderzoek meegedaen hebben (zie laatste kolom van tabel 3.1). Dit feit heeft overigens alleen kuriositeitswaarde, want van de bedrijuen die in 1964/65 deelnamen zijn geen onderzoeksgegevens per bedrijf meer beschikbarr, zodat ook geen vergelijking tussen de twee tijdsperioden te maken valt op basis van deze subgroep van vijftien bedrijven. Door uitbreidingen, inkrimpingen, fusies en dergelijke zijn deze vijftien bedrijven eigenlijk ook niet meer gelijk aan wat ze in $1964 / 65$ waren. 
Het feit dat het hier beschreven onderzoek voor een deel een replikatie is van het onderzoek van Philipsen, betekent dat niet alleen de negentien door hem gebruikte variabelen zijn opgenomen in het onderzoek, maar ook dat de door hem gehanteerde wijze van materiaalverzamelen in grote lijnen gevolgd is.

Hoewel de door Philipsen gebruikte vragenlijst niet meer beschikbaar was, was het wel mogelijk de vragen en koderingen te rekonstrueren uit zijn proefschrift. Bij een parr vragen is noodgedwongen van de oorspronkelijke versie afgeweken. De vragen die onderdeel vormen van de in deze studie te gebruiken variabelen alsmede bedoelde afwijkingen zullen in hoofdstuk 5 in concreto beschreven worden.

Geruime tijd voor het definitieve onderzoek werd er een proefonderzoek bij een bedrijf uitgevoerd on na te gaan of de vragen begrepen werden of dat op bepaalde punten onduidelijkheden optraden. Dit werd uitgevoerd door twee onderzoekers, wardoar twee opinies met betrekking tot de gang van zaken nast elkaar gelegd konden worden.

Het proefonderzoek heeft geleid tot het gebruiken van een andere volgorde in de uiteindelijke vragenlijst, tot eliminatie van een aantal vragen en tot opneming van een zeer beperkt aantal nieuwe vragen, die reeds door andere onderzoekers eerder gebruikt waren. In de definitieve opzet werd met vier verschillende vragenlijsten gewerkt: twee, enkele weken voorafgaande aan het bedrijfsbezoek toe te sturen, vragenlijsten (voor zowel de bedrijfsleider als de personeelschef; deze twee lijsten omvatten voor circa een derdedeel dezelfue vragen voor beide respondenten) en twee tijdens het bedrijfsbezoek mondeling te behandelen vragenlijsten (voor beide respondenten; ook deze interview-vragenl1jsten bevatten voor beide respandenten deels dezelfde vragen).

Het onderzoek werd dus voornamelijk gebaseerd op twee centrale informanten: de bedrijfs- of produktieleider en het hoofd van de afdeling personeelszaken of de personeelschef. Daarnaast werd in elk bedrijf door de onderzoekers gevraagd om semen met de bedrijfsleider of de personeelschef een rondgang door de produktieafdelingen te maken. De score met betrekking tot één variabele (variabele 11: wijze van leidinggeven in het bedrijf) werd op deze observaties van de onderzoekers alsmede op die tijdens de in- 
terviews gebaseerd.

Een vierde informatiebron waren gegevens van het CBS (over de stedelijkheidsgraad; variabele 19) en van het Ministerie van Sociale Zaken over het werkloosheidspercentage van de regio warin het bedrijf lag (variabele 26). De vijfde en laatste informatiebron die gebruikt werd in dit onderzoek betrof uiteraard de NIPG/ TNO-ziekteverzuimstatistiek in verband met de afhankelijke verzuimvariabelen.

Nu terug naar de gebruikte vragenlijsten. De, aan het bedrijfsbezoek voorafgeand, opgestuurde vragenlijsten bevatten gesloten vragen in geprecodeerde vorm. Voor de bedrijfsleider betrof dit onder andere de vragen over vraag/aanbod personeal, stijl van leidinggeven, delegatie van verantwoordelijkheden, invloedsverdeling en kontakten met/over zieke werknemers.

Voor de personeelschef betrof dit ook onder andere delegatie, invloed en kontakten met/over zieken, en daarnaast de tijdsverdeling van de personeelsafdeling en vier pagina's met administratieve gegevens over het personeelsbestand, zoals de personeelsverdeling naar sektoren, dag-/ploegendienst, leeftijdskategorieen, etcetera.

Beide lijsten werden blj het bedrijfsbezoek door de onderzoeker weer in ontvangst genomen. Noch van de bedrijfsleider, noch van de personeelschef werden bij navraag noemenswaardige op- of aanmerkingen vernomen over onduidelijkheden in deze vragenlijsten. Soms bleek de personeelsafdeling echter de administratieve gegevens niet gereed te hebben, zodat die later nagestuurd moesten worden. Tijdens het van te voren afgesproken bedrijfsbezoek werden de bedrijfsleider en de personeelschef gedurende 1 à 2 uren geïnterviewd aan de hand van gesloten en half-gesloten vragen. Van deze resterende vragen werd aangenomen dat enkele iets meer mondelinge toelichting behoefden. Over de inhoud van deze mondelinge toelichting waren overigens van te voren afspraken gemaakt tussen de drie betrokken onderzoekers, zodat daardoor geen (grote) onbetrouwbaarheden zouden kunnen optreden. In dit verband kan ook nog vermeld worden dat, evenals dat bij het onderzoek van Philipsen het geval was, de onderzoekers van te voren zelden of nooit op de hoogte waren van de verzuimcijfers van het te bezoeken bedrijf, zodat daardoor geen vertekeningen kanden optreden.

Tenslotte is nog van belang te vermelden dat de 85 bedrijven alle 
bezocht werden in de periode april - oktober 1981 (veruit het merendeel vóór de zomervakanties). De beschrijuling van de onafhankelijke variabelen in dit onderzoek is dus geënt op de situatie uit de eerste helft van 1981. De als afhankelijke variabelien te gebruiken verzuimcijfers hebben betrekking op het gehele jaar 1980. Dit geringe verschil in referentieperiode werd niet als probleem ervaren, mede gezien de grote stabiliteit die verzuimcijfers van bedrijven plegen te vertonen over de jaren. Korrelaties tussen bijvoorbeeld het verzuimpercentage van twee opeenvolgende jaren over een groot aantal bedrijven hebben meestal waarden van . 80 ̀̀ .90 (zie ander anderen Philipsen, 1969, p. 9, en deze studie, tabel 5.19, p. 146).

\subsection{De konstruktie van de variabelen en de bepaling van hun gebruikswarde}

$\mathrm{Na}$ de beschrijving van de onderzochte bedrijven en de wijze van materiaalverzamelen wordt nu in deze paragraaf vervolgd met de behandeling van de techniek waarmee het onderzoeksmateriaal (de vragen of items) gereduceerd wordt tot variabelen en de techniek waarmee de variabelen op hun gebruikswaarde beoordeeld worden. De gebruikswaarde van een variabele wordt bepaald door zijn spreiding, betrouwbaarheid en validiteit.

Voor een goed begrip wordt vermeld dat er van twee groepen variabelen gebruik wordt gemaakt. De eerste groep bestaat uit de negentien variabelen die Philipsen hanteerde (hoofdstuk 6). Deze worden uiteraard ongewijzigd geaccepteerd. Van reduktie of uitbreiding van het aantal items per variabele is dearbij geen sprake. Wel worden ze geëvalueerd op hun gebruikswaarde. De variabelen die deze beoordeling goed doorstaan, worden te zamen met dertien toegevoegde variabelen (de tweede groep) in de vervolganalyse betrokken (hoofdstuk 7). Uiteraard wordt ook de gebruikswaarde van deze laatste graep belicht.

In verband met de vervolganalyse worden de negentien oorspronkelijke variabelen in hoofdstuk 5 in de eerste plaats op hun apreiding beoordeeld. Degene met een geringe spreiding over de 85 bedrijven worden voor de vervalganalyse geëlimineerd. Geringe 
spreiding betekent dat alle bedrijven ongeveer even hoog of even laag scoren op de betreffende variabele of subvariabele. Geringe spreiding behoeft overigens - dat zal duidelijk zijn - niet per se te betekenen dat de variabele invalide of onbetroumbar is. De eliminatie van degene die slecht spreiden geschiedt omdat variabelen met een geringe spreiding ook geen sterke verbanden met andere variabelen kunnen opleveren en voor het onderzoek dus geen bruikbare funktie hebben.

Voorts wordt de betroumbaarheid van de variabelen bekeken. Bij het merendeel van de één-item variabelen zal de betrouwbarheid niet zo'n groot probleem zijn, omdat zij berusten op systematisch bijgehouden dokumentatie - waar overigens wel detailfouten in voor kunnen komen. Bij deze dokumentatievariabelen zal het probleem eerder in de non-respons of in de vallditeit - representeert de dokumentatie het begrip-zoals-bedoeld? - zitten.

Van variabelen die uit meerdere onderdelen bestaan wordt de interne konsistentie vastgesteld. Deze wijze van betrouwbarheidsmeten kamt er in feite op neer dat nagegaan wordt hoe hoog de interkorrelaties zijn tussen de onderdelen van het instrument. Een hoge interne konsistentie van een instrument betekent dat de samenstellende delen bij elkaar horen en dat optelling van de delen tot het geheel zin heeft. Behalve berekening van de interne konsistentie wordt bij sommige variabelen ook nog de zogenaamde interrater- of interbeoordelaarsbetroumbaarheid berekend. Ter verhaging van de betrouwbarheid van de meetinstrumenten zijn name$1 i j k$ variabelen die op min of meer subjektieve meningen gebaseerd zijn, bijvoorbeeld delegatie en hinder van werkomstandigheden, aan twee in plaats van aan één respondent voorgelegd. Om na te gean of de twee respondenten (bedrijfsleider en personeelschef) in hun antwoorden op de betreffende vraag ongeveer overeenkomen, worden tweevoudige variantie-analyses uitgevoerd. Hierbij gaat het als het ware om twee onafhankelijke variabelen (enerzijds de 85 bedrijuen en anderzijjs de twee respondenten) en één afhankelijke variabele, namelijk de score op de betreffende vraag. De resultaten van deze variantie-analyses kunnen aantonen of de score op de afhankelijke variabele voornamelijk bepaald wordt door verschillen tussen de respondenten of door verschillen tussen de bedrijuen of door beide. Vragen, warvan de scores geheel of gedeeltelijk bepaald worden door de versichillen tussen de respondenten en niet door de verschillen tussen de bedrijven, kunnen 
geëlimineerd worden. In zo'n geval is er namelijk sprake van een lage interbeoordelaarsbetrouwbaarheid. Er mag dan van uitgegaan worden dat beide respondenten dezelfde bedrijfssituatie of hetzelfde bedrijfsaspekt in grote lijnen op dezelfde wijze beoordelen/waarderen.

Wat betreft de eis van validiteit (representeert de variabele het begrip-zoals-bedoeld?), worden in de methodologische literatuur meestal een tweetal vormen van validiteit onderscheiden. Ten eerste acht men een instrument valide indien dit een criteriumvariabele (bijvoorbeeld ziekteverzuim) goed voorspelt; wat het instrument dan zelf voorstelt is van sekundair belang. Men spreekt dan over prediktieve validiteit. Een tweede vorm is de inhoudsvaliditeit, waarbij het gaat om de vraag of het instrument inhoudelijk overeenstemt met het begrip-zoals-bedoeld. Een manier om na te gaan of het instrument op deze wijze valide geacht mag worden is om het te korreleren met reeds als vallde aenvaarde soortgenoten. Zo kan bijvoorbeeld een nieuw-ontworpen leiderschapsindex gevalideerd worden aan reeds bestaande instrumenten met betrekking tot leiderschap. Overigens is de betrouwbarheid van een instrument een noodzakelijke voorwaarde voor de validiteit ervan. Of anders gezegd: een instrument kan ook invalide zijn omdat het onbetrouwbaar is.

Bij de negentien variabelen die van Philipsen overgenomen zijn, is het probleem van de validiteit beperkt door het feit dat gebruik wordt gemaakt van eerder toegepaste meetinstrumenten, die over het algemeen een redelijke mate van zowel inhouds- als prediktieve validiteit hadden vertoond. Toch zullen in hoofdstuk 6 de negentien variabelen uit de replikatie-analyse besproken worden met betrekking tot hun validiteit. Een aantal van deze variabelen zal, vanwege gebrekkige validiteit (of betrouwbarcheid) afvallen voor de vervolganalyse.

In hoofdstuk 7 worden dertien nieuwe variabelen toegevoegd aan de overgebleven variabelen. Wat betreft de konstruktie van deze variabelen kan allereerst vermeld worden dat daarbij rekening wordt gehouden met de validiteitseisen door zoveel mogelijk gebruik te maken van reeds door andere onderzoekers gebruikte instrumenten. Ten aanzien van de nieuwe instrumenten is er uiteraard bij énitem-variabelen geen sprake van reduktie van meer vragen tot één variabele. Hierbij gaat het in concreto om thet werkloosheidsper- 
centage van het rayon waarin het bedrijf ligt, het percentage buitenlandse werknemers, de gemiddelde groepsgrootte in de produktie, de (relatieve) omvang van de personeelsafdeling en de snelheid van de verzuimkontrole.

De acht toegevoegde mér-item-variabelen zullen meestal gekonstrueerd worden door middel van een reduktietechniek, namelijk faktoranalyse. Bij deze variabelen wordt uitgegaan van bijvoorbeeld vijf op het eerste gezicht bij elkaar horende vragen of items, die door middel van faktoranalyse gereduceerd worden tot bijvoorbeeld twee of drie items, die empirisch sterk bij elkar blijken te horen en die dan te zamen tat één variabele worden benoemd. Faktoranalyse speelt hier dus een rol bij de gebruikswaarde van variabelen. Het gaat hierbij in concreto om de financieelekonomische positie van het bedrijf, de produktieproces-aspekten, socíal en instrumenteel leiderschap, invloedsverschillen tussen leiding en uitvoerenden, de personeelsbegeleiding en -zorg vanuit de personeelsafdeling en de kontakten over de zieke werknemers. Van de dertien toegevoegde variabelen zal eveneens de spreiding, de interne konsistentie, de interbeoordelaarsbetrouwbarheid (voor zover van toepassing) en de validiteit weergegeven en beoordeeld worden.

\subsection{Het analyseplan en de analysetechnieken}

In hoofdstuk 5 zullen de uiteindelijk gekozen 32 verklarende variabelen en de drie verzuimmaten beschreven worden. Vervolgens zullen in de hoofdstukken 6 en 7 twee aparte analyse-onderdelen gerapporteerd worden.

De replikatie-analyse, die in hoofdstuk 6 verslagen zal worden, zal uit twee centrale onderdelen bestaen. Ten eerste zal nagegaan worden - door middel van faktoranalyse - welke in 1980/81 de interne struktuur is van de negentien verklarende variabelen die Philipsen in 1964/65 gebruikte. Ten tweede zullen de negentien variabelen en de drie verzuimmaten met behulp van een partiële korrelatie-analyse onderzocht worden, warbij toetsing van de veronderstelde verbanden het doel is. Daarbij zal verslag gedaan worden van polynomiale regressie-analyses die uitgevoerd worden om na te gaen of de verbanden tussen de verklarende variabelen en de verzuimmaten rechtlijnig of kromlijnig zijn. Het aksent bij de 
analyses zal liggen op de vergelijking van de uitkomsten in 1964/ 65 met die uit 1980/81. Hoofdstuk 6 zal eindigen met een korte bespreking van de validiteit van de negentien variabelen. Vervolgens zullen in hoofdstuk. 7 in de vervolganalyse acht ven de negentien variabelen, die door Philipsen ontwikkeld waren en die om uiteenlopende redenen niet meer voldoen, geëlimineerd worden. Voor vijf van deze acht zullen nieuwe voorgesteld worden, die een goed alternatief lijken te vormen voor de oorspronkelijke vijf. Bovendien zullen nog acht nieuwe variabelen aan dit saldo toegevoegd worden. Dit betekent dat er 24 verklarende variabelen voor de vervolganalyse in aanmerking komen. Bij de eliminatie en de toevoeging van deze variabelen zal ervoor gezorgd worden dat het onderlinge 'evenwicht' erin niet verstoord raakt; dat wil zeggen dat de zes hoofdonderstellingen op evenwichtige wijze geïndiceerd zullen blijven door de 24 uiteindelijkk gekozen variabelen.

Eerst zal weer de interne struktuur van deze 24 variabelen weergegeven worden. Deze struktuur zal uitwoerig besproken worden tegen de achtergrond van eerder gepubliceerde organisatie-sociologische literatuur.

Vervolgens zal door middel van regressie-analyse nagegaan worden of de opgestelde hypothesen met betrekking tot de verbanden tussen de 24 verklarende variabelen en de verzuimmaten houdbaar zijn. De relaties van de dertien toegevoegde variabelen met de verzuimmeten zullen ook weer op kromlijnigheid worden getoetst. $\mathrm{Na}$ een ruime bespreking van de relaties van de verklarende variabelen met de verzuimmaten en van de validiteit van de toegevoegde verklarende variabelen, zal naar integratie van de variabelen gestreefd worden. Dit $z$ al geschieden door de - door middel ven faktoranalyse gevonden - zeven faktoren te relateren aan de drie verzuimmaten. Op deze wijze kunnen de onderzoeksresultaten als het ware op globale wijze samengevat worden.

Het laatste onderdeel van de vervolganalyse in hoofdstuk $7 \mathrm{zal}$ bestaan uit de analyse van een aantal kausale modellen. Door middel van de analysetechniek 'LISREL' (Linear Structural Relations; zie Jöreskog \& Sörbom, 1978) zal namelijk getracht worden de vraag te beantwoorden of voor de variabelen die binnen de belangrijkste van de zeven faktoren voorkomen èn het verzuilmpercentage, een plausibel kausaal model opgesteld kan worden dat te verenigen is met de tussen de variabelen optredende korrelaties of kovarianties. 


\subsection{Verzulmonderzoek op verschillende analysenivo's}

In veruit het grootste deel van het onderzoek naar de oorzaken van ziekteverzuim is de individuele werknemer het objekt van analyse. In deze studie is dat niet het geval; hier zijn namelijk organisaties de analyse-eenheden. Dit verschil in aanpak behoeft toelichting.

In de soclologie (met name in de onderwijs- en organisatie-sociologie), in de ekonomie en in de politikologie worden er vaak boven-individuele of zogenaamd geaggregeerde eenheden in analyses gebruikt. Schoolklassen, scholen, afdelingen, bedrijven, inkomens-, leeftijds- en bevolkingsgroepen, gemeenten, provincies en zelfs landen vormen dan de studie-objekten. Soms hanteert men deze eenheden ondat men niet beschikt over gegevens van individuen, soms ook omdat men bewust geïnteresseerd is in de verschillen tussen deze eenheden. De 'aggregatie-benadering' is niet nieuw, want de studies van Durkheim over zelfmoord en religie van rond de eeuwwisseling werden reeds met gemeenten als analyse-eenheid uitgevoerd.

Het zal geen verbazing wekken dat in verzuimonderzoek psychologen over het algemeen meer het individu als analyse-eenheid hebben gebruikt en sociologen meer de afdeling of de organisatie.

In de Verenigde Staten en Engeland is de analyse van de determinanten van ziekteverzuim bijna geheel een psychologische aangelegenheid. Het verschijnsel wordt daar in de regel door psychologen bestudeerd met variabelen die vooral in psychologische theorieën voorkomen, en met het individu als analyse-eenheid. Dit blijkt onder andere uit het veelvuldig gebruik van begrippen als arbeidssatisfaktie, involvering, binding, taakwariatie, zelfstandigheid in het werk, leeftijd en diensttijd.

De situatie in Nederland verschilt van die in de Angelsaksische landen, omdat hier twee sociologen - Lammers (1966) en Philipsen - in het verleden sterk hun stempel hebben gedrukt op de theorievorming en het onderzoek rond verzuim. Hun publikaties hebben veel aandacht gekregen en hun organisatie-sociologische perspek- 
tief is ook terug te vinden in latere publikaties (onder anderen van Dijkstra, 1977; Ris, 1978). Deze benadering houdt in dat het verschijnsel verzuim op een nivo boven dat van het individu (dus de afdeling, de werkgroep, het bedrijf) bestudeerd wordt met begrippen die deze boven-individuele eenheden trachten te beschrijven. De verzuimmat is dan een afdelings- of bedrijfsgeaiddelde . Verklarende variabelen zijn in deze anpak sociologische (bovenindividuele) begrippen als de produktiewijze, de organisatiestruktuur (grootte, span of control, groepsgrootte), het personeelsbeleid, de wijze van verzuimkontrole, het 'bedrijfsklimat', etcetera. Begrippen die door de organisatie-vergelijkende methode buiten het onderzoek zullen moeten blijven zijn onder andere demografische en persoonlijkheidskenmerken van individuen.

Beide benaderingen hebben dus hun voor- en nadelen, respektievelijk eenzijdigheden. De 'individuele benadering' heeft het voordeel dat de invloed van de medische en individuele kenmerken op het verzuim goed belicht kan worden, terwijl bij de 'organisationele benadering' de invlaed van de vaak beleidsrelevante organisatiekenmerken goed tot uiting gebracht kan worden.

De impliciete veronderstelling bij de organisatie-vergelijkende aanpak is overigens vaak, dat de bestudeerde objektieve kenmerken van de organisatie en van het personeelsbestand de sociaal-psychologische processen bepalen die ertoe leiden dat werknemers zich ziek of beter melden. In dit verband merkte Gadourek (1970), bij de bespreking van het onderzoek van Philipsen (1969) op, dat zijn theorie over individueel gedrag (verzuim) van werknemers gaat en dat deze getoetst wordt met kenmerken van collectiva (bedrijven). Dit betekent dat alleen indirekte toetsing van de theorie mogelijk is. Bijvoorbeeld niet de werkelijke sociale binding aan het bedrijf, zoals beleefd door werknemers, wordt gemeten en getoetst maar de kanaen op dergelijke binding, aldus Gadourek. Philipsen introduceerde trouwens zelf de term 'kansen' (op binding, beheersing, etcetera). Hij was zich dus wel van deze indirektheid van de toetsing van de theorie bewust.

4.2 Voor-en nadelen van verschillende analysenivo's

Voor de met het begrip analyse-eenheid samenhangende methodische 
en statistische problemen is sinds een jaar of tien meer en meer belangstelling ontataan. Voor wat betreft het orgenisatie-onderzoek hebben Roberts et al. (1978) een antal problemen besproken, maar tot duidelijke aanbevelingen of richtlijnen komen zij helaas niet. Eén ding is wel helder: niet elk analysenivo kan zó maar, zonder goede redenen worden toegepast. Men moet het analysenivo dus theoretisch kunnen beargumenteren. Dat is echter nilet in alle gevallen eenduidig mogelijk. Uit de literatuur over het onderwerp ziekteverzuim (zie bijvoorbeeld Smulders, 1984) is wel duidelijk dat in het verzuim, als individueel gedrag, zowel individuele, groeps-, organisatie-, als algemeen maatschappelijke kenmerken een rol spelen. Dit betekent dat in principe meerdere analysenivo's verdedigbaar zijn.

Indien men zich tot organisatiekenmerken beperkt, zoals in deze studie, is analyse met organisaties dus te rechtvaardigen. Men dient zich er dan wel van bewust te zijn dat men niet meer praat over verschillen in verzuim tussen individuen. Het is trouwens evengoed te rechtvaardigen om de invloed van organisatiekenmerken op verzuim te analyseren met individuen, omdat verzuim in principe toch individueel gedrag is. Deze wijze van analyse is trouwens ook toegepast (bijvoorbeeld door Rousseau, 1978).

Er is een drietal redenen aan te duiden waram analyse van verzuim op geaggregeerd nivo voordelig kan zijn. De eerste is dat op individueel nivo de individuele variabiliteit in de gezondheidstoestand zo sterk in het verzuim uitgedrukt is, dat niet-medische c.q. sociale invloeden alleen nog maar zwak herkenbaar zijn. Een werknemer bijvoorbeeld, die aan astma lijdt maar in een heel goede arbeidssituatie werkt, zal een verzuim vertonen dat weinig of niets te maken heeft met zijn tevredenheid over die situatie. Zo zal oak het verzuim van een ontevreden werknemer met een uitstekende gezondheid slechts een zwakke afspiegeling zijn van zijn onvrede met zijn werksituatie. Op geaggregeerd nivo zijn deze individuele gezondheidsverschillen tot op grote hoogte 'uit-gemiddeld'. Wat er dan nag te verklaren overblijft betreft voornamelijk sociaal relevante verschillen tussen groepen of organisaties. Door de overgang van het individueel naar het geaggregeerd nivo zullen overigens ook andere typisch individuele kenmerken, zoals individuele oriëntaties, persoonlijkheidskenmerken, riskante gewoonten, etcetera, zo goed als uitgeschakeld worden. Philip- 
sen (1970) heeft deze problematiek behandeld in verband met de zwakke relatie tussen arbeidssatisfaktie en verzuim op individueel nivo.

Verder zou men kunnen stellen dat er een tweede reden kan zijn om verzuim op geaggregeerd nivo te analyseren, namelijk als er binnen bedrijven een grote homogeniteit aan klimaat of kultuur bestaat. Dan is het goed om de verschillen in verzuim tussen organisaties onder de loupe te nemen.

Recentelijk hebben Chadwick-Jones et al. (1982) gewezen op de vaak grotere verschillen in verzuim tussen organisaties dan binnen organisaties. Bedoelde organisatieverschillen in verzuim waren te verklaren door middel van variabelen als het sanktiebeleid, vakbondsaktiviteiten binnen bedrijven en 'spans of control'. Johns en Nicholson (1982) beseerden zich op de gegevens van Chadwick-Janes et al. Zij menen dat verschillen tussen organisaties vooral belangrijk worden om te onderzoeken wanneer er binnen organisaties grote homogeniteit bestaat ten aanzien van klimaat en/of kultuur. In dat geval is er namelijk binnen één organisatie weinig variantie in de betrokken onafhankelijke en afhankelijke variabelen en zullen de korrelaties ook laag zij.jn. In $z 0^{\prime} n$ geval kunnen kulturele of klimaatsverschillen de verschillen in verzuim tussen organisaties geheel of gedeeltelijk verklaren.

Tenslotte is er nog een derde reden waarom analyse op geaggregeerd nivo aanbevelenswaardig kan zijn. Verzuimde dagen zijn namelijk scheef verdeeld over individuen: in een bepaalde warnemingsperiode zijn er veel werknemers zonder verzuim (met een 0 waarde) en een relatief gering aantal met veel verzuim. Bij afdelingen of organisaties is het verzuimpercentage echter meestal normaal verdeeld, omdat op dat nivo de warden op gemiddelden gebaseerd zijn. Het effekt van de scheve verdeling op individueel nivo is, dat bij korrelatie- en regressierekening de koëfficiënten aan de lage kant zullen zijn (zie Hammer \& Landau, 1981). De oplossing bij dergelijke abnormale verdelingen - transformatie tot een normale verdeling - heeft hier vanwege het grote aantal 0 -waarden weinig zin. Wel kan het effekt van de scheve verdeling enigszins verminderd worden door toepassing van bepalde statistische analysetechnieken (zie ook Hammer \& Landau, 1981), door verlenging van de observatieperiode (waardoor het antal 0-waar- 
den minder wordt) en door vergroting van de onderzoekspopulatie/ steekproef. Toch kan het probleem van de scheve verdeling - en daardoor de meestal lage korrelaties met andere variabelen op individueel nivo nooit geheel uitgeschakeld worden. Zoals gezegd, op een hoger aggregatienivo is dit probleem meestal niet aanwezig en zullen de korrelaties hierdoor (er zijn ook nog andere redenen) meestal hoger zijn.

Het onderzoeksmateriaal van Gadourek (1965) is heel geschikt om een deel van bovenbeschreven materie met behulp van cijfers toe te lichten. Deze auteur verzamelde via vragenlijsten persoons- en arbeidssituatiekenmerken en verzuimgegevens van 2209 mannelijke werknemers uit 21 Nederlandse produktiebedrijven. Deze werknemers kanden in 106 natuurlijke werkgroepen ingedeeld worden. Eén van de door Gadourek gekonstrueerde variabelen betrof de vraag of men last had van duizelingen, maagklachten, slapeloosheid, hartkloppingen, etcetera. Dus een vraag naar de individuele gezondheidsklachten.

Bij de 2209 individuen vertoont deze variabele met de verzuimfrekwentie een relatie van $r=.12$ en met het verzuimpercentage van $r=.09$ (Gadourek, 1965, tabel 29, tegenover p. 122). Bij de 106 groepen zijn deze korrelaties respektievelijk $\mathbf{r}=.09$ en $\mathbf{r}=.10$ (tabel 28, tegenover p. 120). Op het eerste gezicht lijkt het er dus op dat deze variabele op beide nivo's ongeveer evenveel verklaart van de twee betrokken verzuimmaten.

Men moet hierbij echter bedenken dat op het individueel nivo de variantie in de verzuimmaten veel groter is dan op het groepsnivo. Im precies te zijn was de standaard-deviatie voor de frekwentie bij de 2209 individuen 0,89 gevallen per persoon per 6 maanden en bi.j de 106 groepen 0,33 gevallen per persoon per 6 maanden (p. 98). Dit betekent dat bovenbeschreven klachtenvariabele op individueel nivo in feite méér variantie van de frekwentie verklaart, namelijk $(.12)^{2} \times(.89)^{2}=.01$ gevallen per persoon, dan op groepsnivo, namelijk $(.09)^{2} \times(.33)^{2}=.001$ gevallen. Hetzelfde geldt voor het verzuimpercentage.

Dit voorbeeld laat zien dat bedoelde variabele vooral op individueel nivo werkzaam is en veel minder op groepsnivo. Op organisatienivo zou de invloed van deze variabele waarschijnlijk nihil zi.jn geworden.

Dok kan met behulp van het materiaal van Gadourek aangetoond wor- 
den dat andere variabelen juist 'opkomen' als gegean wordt van Individuen nar groepen. Nemen we bijjvoorbeeld de vraag naar de stoffigheid van de ruimte warin men werkt. Bij de individuen heeft deze variabele met de frekwentie een korrelatie van $r=.09$ en met het verzuimpercentage van $r=.12$. Bij de groepen zijn deze korrelaties respektievelijk $r=.30$ en $r=.53$. Dit betekent zelfs als rekening gehouden wordt met de verlaagde standaard-deviaties van het ene naar het andere nivo - dat deze variabele op groepsnivo veel sterker werkzaam is dan op individueel nivo.

Een konklusie hieruit kan ook zijn dat het vinden van sterke verbanden met verzuim op organisatienivo nog geen gunstig teken hoeft te zijn. Op individueel nivo is de variabiliteit namelijk meestal 0 - 365 dagen ofwel 0 - 100 procent, terwijl op organisatienivo het verzuimpercentage near schatting tussen 3 en 20 procent zal liggen. De hoge korrelaties bij organisaties hebben dan dus betrekking op een relatief geringere variabiliteit.

In deze $z$ in moeten waarschijnlijk ook de onderzoeksresultaten van Fitzgibbons en Moch (1980) en van Watson (1981) met individuen, en van Philipsen (1969) en van Dijkstra (1977) met organisaties gezien worden.

Fitzgibbons en Mach analyseerden de verzuimfrekwentie van circa 400 produktiewerknemers van één bedrijf over een periade van één jaar. Zij bereikten met elf persoons- en takvariabelen een $R^{2}$ van minder dan .20 . Ook Watson verklaart met dertien persoons- en taakvariabelen slechts 22 procent van de verschillen in verzuim tussen individuen $\left(R^{2}=.22\right)$. Het ging hier om het verzuimpercentage van 116 produktiewerknemers van één bedrijf over een periode van 15 maanden.

Aan de andere kant blijkt dat onderzoeken die verschillen in verzuim tussen organisaties trachten te verklaren, veel hogere multipele korrelaties opleveren. Philipsen (1969) bijwoorbeeld, verklaarde met negentien sociaal-wetenschappelijke variabelen bij 83 produktiebedrijven circa 64 procent van de verschillen in de verzuimf rekwentie en verzuimduur tussen de bedrijven $\left(R^{2}=.64\right)$. Ook Dijkstra (1977) bereikte met 23 variabelen bij 56 produktie-organisaties voor gehandicapten gelijksoortige hoge percentages van verklaarde variantie.

Zoals gezegd, de variantie (het kwadraat van de standaard-deviatie) in het verzuim is op individueel nivo veel hoger den op or- 
ganisatienivo. En hoewel we hier niet beschikken over bedoelde spreidingsgegevens van alle vier genoemde onderzoekingen, kunnen we gevoegel $1 j k$ aannemen dat de verklaarde varianties bij de organisaties betrekking hebben op een kleinere spreiding in het verzuim dan bij de individuen.

Pedhazur (1982, p. 539) heeft deze problematiek ook besproken met betrekking tot scholen als analyse-eenheid. In navolging van hem kunnen we ook stellen: bij vergelijking van organisaties op het punt van verzuim, schakelen we de variantie binnen de organisaties uit en verklaren de variantie tussen de organisaties. Analoog kan men stellen dat als men het verzuim van individuele werknemers van één bedrijf analyseert, men alleen het verzuim tussen de individuen verklaart en niet in staat is de variantie in het verzuim, die er bestaat tussen het betrokken bedrijf en andere bedrijven, te verklaren. Hierop hebben Johns en Nicholson (1982), zoals vermeld, gewezen.

\subsection{Andere problemen van organisationele analyse}

$\mathrm{Na}$ voorgaande, meer op verzuim gerichte beschouwing van het vraagstuk van de verschillende analysenivo's, zal hier tenslotte enige aandacht geschonken worden aan de meer algemene problematiek van verschillende nivo's. Centraal zal staan wat deze verschillen in nivo voor effekt hebben op de konklusies die men zou kunnen trekken. Variabelen kunnen zich op individueel nivo en boven-individueel (groeps-, organisatie-)nivo op verschillende wijzen tot elkaar verhouden. Ten eerste kan de variabele op bovenindividueel nivo tot stand zijn gekomen door middel van aggregatie. Bijvoorbeeld de leeftijd van individuen wordt dan bij groepen of organisaties de gemiddelde leeftijd van de groeps- of organisatieleden.

Ten tweede bestaan er in de organisatie-sociologie ook nog andere verhoudingen tussen beide nivo's. Voorbeelden daarvan zijn centralisatie-, formalisatie- en technologiematen die bij individuen anders gemeten worden dan bij organisaties: in het eerste geval bijvoorbeeld door midde $\mathbb{l}$ van vragenlijsten onder de werknemers en in het tweede geval door middel van een mondelinge verklaring van één sleutelinformant of door middel van een objektieve dokumentatie-index. 
Eerst iets over de problematiek van de wijze van aggregatie. Hannan en Burstein (1974) en Pedhazur (1982) hebben beargumenteerd dat bepalde vormen van aggregatie kunstmatig tot hogere korrelaties leiden. Dit geschiedt namelijk als de analyse-eenheid op hoger nivo tot stand is gekomen door groepering/aggregatie op basis van een onafhankelijke of afhankelijke variabele (bijvoorbeeld leeftijdsklassen of verzuimklassen; hierbij worden dus individuen van angeveer gelijke leeftijd of ongeveer gelijk verzuim in één klasse samengebracht), hetgeen in het onderzoek van Philipsen en in het onderhavige niet het geval is.

Een tweede probleem hierbij is dat een variabele bij geaggregeerde eenheden soms iets anders, meestal méér, kan meten dan zijn soortgenoot bij individuele eenheden (Firebaugh, 1978). Dit is bijvoorbeeld het geval bij een individuele werknemer met een hoge scholingsgraad versus een bedrijf met een gemiddeld hoge scholingsgraad. In het eerste geval zegt de variabele iets over het soort werk en de arbeidsmarktpositie van de werknemer, en in het laatste gevall zegt de variabele warschijnlijk ook nog lets over de produkten die vervaardigd worden, over de wijze waarop het werk georganiseerd is en mogelijk ook over het vestigingsgebied van het bedrijf. Op geaggregeerd nivo zou de relatie van scholingsgraad met andere variabelen dus verschillend kunnen zijn van deze relaties op individueel nivo.

Vervolgens enige opmerkingen over de vermelde problematiek van de wel gelijkluidende, maar inhoudelijk toch niet geheel identieke variabelen op verschillende nivo's. De variabele technologie (routinematig werk van individuen versus massaproduktieproces van een organisatie, die beide als technologie-variabele zijn opgevoerd) is thier een goed voorbeeld van.

Een aantal organisatie-sociologen heeft zich empirisch beziggehouden met het vraagstuk van het al dan niet overeenkomen van relaties tussen variabelen bij organisaties respektievelijk individuen. Pennings (1973) trachtte in tien organisaties na te gaen wat het verband was tussen de meting van centralisatie en formalisatie op organisatie- respektievelijk individueel nivo. Bij de organisaties gebruikte hij dokumenten en informatie van sleutelinformanten, zoals de Aston-onderzoekers dat deden (institutionele methode) en bij individuen vragenlijsten die aan werknemers werden voorgelegd (survey- of vragenlijstmethode). 
Zowe $\mathbb{l}$ bij centralisatie als bij formalisatie korreleerden de maten gemeten via de institutionele respektievelijk vragenlijstmethode negatief en meten dus blijkbaer iets anders. Pennings suggereerde dat de institutionele methode voornamelijk aan de produktieaektor refereerde, terwijl de vragenlijstmethode meer op de organisatie als geheel toegespitst was en dat dit de oorzaak voor het ontbreken van convergentie tussen beide methoden zou kunnen zijn.

Terecht merkt Lammers (1983, p. 488-489) op dat beide methoden in feite respektievelijk vormkenmerken van de organisatie en kenmerken die de feitelijke gang van zaken beschrijven, sonderen. Met andere woorden; de gebrekkige convergentie zou zijn oorzaak vinden in het feit dat verschillende zaken worden gemeten en niet in het feit dat het om verschillende nivo's of referentie-eenheden gaat.

Sathe (1978) deed eenzelfde soort onderzoek als Pennings met de variabelen centralisatie, formalisatie en specialisatie. In één organisatie vergeleek hij de interviewgegevens van één sleutelinformant per afdeling met de vragenlijstgegevens van de 531 werknemers van de (22) afdelingen. Doordat het hier om afidelingen ging, kon de door Pennings geopperde referentie-verandering niet meer van kracht zijn. Uit het resultaat van het onderzoek bleek opnieuw dat de zogenaamde institutionele en vragenlijst-instrumenten met betrekking tot dezelfde variabele matig convergeerden. Belangrijk is dat Sathe opmerkt dat het institutionele instrument meer de 'bedoelde' of 'ontworpen' organisatiestruktuur meet, de vragenlijstmethode daarentegen meer de 'ervaren' of 'zich ontwikkeld hebbende" struktuur (de praktijk van alle dag). Daardoor $z i j n$ de negatieve of zwakke korrelaties niet zo vreend meer. Sathe trekt dus ongeveer dezelf de konklusie als Lammers. Als laatste heeft ford (1979) zich empirisch met de twee verschillende meettechnieken beziggehouden. Hij meende dat de convergentie tussen beide meetmethoden toe zal nemen als, bijvoorbeeld door leiderschapsprocessen, de 'bedoelde' struktuur zoveel mogelijk met de ' $z$ ich ontwikkeld hebbende" struktuur samenvalt. In een evaluatie van bovenomschreven en andere organisatiestudies heeft Walton (1981) gesuggereerd dat er drie redenen kunnen zijn waarom er geen convergentie bestaat tussen methoden om organisatiekenmerken te meten. Hij doelde daarbij op verschillen in de mate van objektiviteit van de dataverzamelingstechnieken (vragen- 
lijsten, interviews, observaties, analyse van dokumenten en statistieken), verschillen in de bronnen (één of meerdere informanten, direkte of indirekte bronnen) en verschillen in focus of referentie (taak, rol, produktiesektor, organisatie als geheel). Walton meende dat men bij vergelijking van de organisatie-gerichte en individu-gerichte onderzoeksmethode met bovenstaande indelingscriteria dient rekening te houden. Anders loopt men de kans "appels met peren' te vergelijken.

\subsection{Kanklusies}

Als afsluiting kunnen nog enige konklusies getrokken worden die betrekking hebben op de door Philipsen (1969) en in deze studie gehanteerde organisatie-vergelijkende benadering van het verzuim.

- de benadering is geschikt om sociologische, organisatiegebonden variabelen in relatie te brengen met verzuim in bedrijven;

- door de benadering worden de typisch medische en typisch individuele oorzaken van het verzuim grotendeels onder kontrole gehouden;

- de aanpak verdient vooral aanbeveling indien de verschillen in verzuim tussen de bedrijuen groot zijn (en de verschillen in verzuim tussen de werknemers binnen de bedrijuen klein);

- de benadering gaat uit van de veronderstelling dat kenmerken van bedrijven invloed hebben op gevoelens van werknemers, bijvoorbeeld op de mate van satisfaktie of binding, en - via deze gevoelens - op het gedrag van werknemers, met name hun verzuim. De verzuimtheorie met betrekking tot de relatie binding - verzuim wordt dus op indirekte wijze getoetst;

- om statistische redenen, namelijk door verkleining van de variantie in het verzuim bij aggregatie, zullen in de organisatie-vergelijkende benadering de verbanden tussen de verklarende variabelen en het verzuim over het algemeen hoger uitvallen dan in de individu-vergelijkende benadering;

- ook zullen de verbanden op organisatienivo hoger zijn vanwege de minder scheve verdeling van de verzuimmaten op dat nivo; 
- omdat er in de door Philipsen (1969) en in deze studie gevolgde methode geen aggregatie/groepering van variabelen van het individueel naar het organisatienivo plaatsvindt op basis van onafhankelijke of afhankelijke variabelen zelf (bijvoorbeeld leeftijdsklassen of verzuimklassen), kan dit geen reden zijn dat verbanden op organisatienivo (kunstmatig) hoger zouden zijn dan op individueel nivo;

- niet alle organisatie-vergelijkende methoden meten hetzelfde: de door Pennings (1973) en Sathe (1978) gebruikte methode om organisatiekenmerken via dokumentatie en sleutelinformanten vast te leggen (de Aston-methode) was sterk gericht op de organisatiestruktuur zoals die door de leiding ontworpen was; de methode die Philipsen (1969) toepaste om bijvoorbeeld kenmerken van centralisatie (leiderschap en delegatie) en produktiewijze vast te leggen, richtte zich veel meer op de organisatie zoals die zich ontwikkeld had. Bij deze methode zal daarom ook waarschijnlijk de convergentie met een eventueel toe te passen vragenlijstmethode onder werknemers groter zi.jn.

Deze paragraaf kan tenslotte afgesloten worden met te benadrukken dat men zich steeds bewust dient te zijn welk analysenivo men hanteert. In het ene geval tracht men verschillen in verzuim tussen individuen te verklaren en in het andere geval verschillen in verzuim tussen organisaties. Vaak worden de konklusies die gelden voor de organisaties, geëxtrapoleerd naar de individuen. Meestal gebeurt dat op goede gronden. Toch moet men in feite altijd een slag om de arm houden om geen "drogreden van het verkeerde nivo' te begaan. Dearom zal er in deze studie ook steeds gesproken worden over verschillen in verzuim tussen organisaties en niet over verschillen in verzuim tussen individuen. 


\subsection{Het hypothetisch schema met de 32 verklarende variabelen}

Omdat een deel van het empirisch onderzoek een replikatie van het onderzoek van Philipsen betreft, behoeft de keuze van de door hem gekozen variabelen ( 1 tot en met 19 ) geen nadere toelichting. In het onderzoek zullen echter nog dertien andere variabelen (20 tot en met 32) opgenomen worden, waarvan het wel noodzakelijk is te beargumenteren om welke redenen zij erbij betrokken zijn.

Ter inleiding daarop is het goed on het hypothetisch schema van het onderzoek van Philipsen eerst kort te bespreken. Zoals reeds in hoofdstuk 2 werd beschreven, ontwikkelde Philipsen (1969, p. 68-83) - op basis van begrippen van De Groot (1958), March en Simon (1958) en Lammers (1964) - een theorie om verschillen in verzuim tussen arganisaties mee te verklaren. De centrale gedachte van deze theorie was dat gevoelens van verbondenheid met de organisatie (ofwel binding) van belang zijn voor het verzuim. De instrumentele en sociale binding aan de werksituatie worden geacht de verzuimfrekwentie te beperken (respektievelijk kolom II en II I in tabel 5.1). Binding werd geacht geen invloed te hebben op de verzuimduur.

Dok de van Lammers afkomstige begrippen sociale en ekonomische dwangmiddelen werden in het theoretisch schema opgenomen, namelijk als sociale verzuimkontrole (-gelegenheid) (kolom VI) en als ekonomische en/of verzekeringstechnische verzuimkontrole (-gelegenheid) (kolom V). Sociale kontrole werd verondersteld de frekwentie te beperken, terwijl ekonomische en/of verzekeringstechnische kontrole zowel met de frekwentie als met de duur in verband werd gebracht.

Philipsen voegde aan bovenstaande koncepten van Lammers drie andere toe. Het gaat hierbij ten eerste om de gezondheidsvariabele objektieve en/of subjektieve verzuimnoodzaak, afkomstig uit het werk van De Groot (1958) (kolom I). De door Philipsen toegevoegde bijvoegelijke naamwoorden objektief en subjektief hebben betrekking op respektievelijk de hoeveelheid en ernst van de aandoeningen ('het aanbod') en de mate waarin men zich bij eenzelfde 'aanbod' afwezlg meldt of afwezig blijft ("de persoonlijke weerstand" 
Tabel 5.1 Verondenatelde partible relatiea tusen de verklarende variabelen en de verzuim tekwentie en -dunim

$F=$ rekwentie

$D=$ gendidelde dut per geval

* = pos 1 ief verband werondersteld

- = negalief verband verandersteld

$0=$ geen alonifikmit verband verandersteld

$U=k \mathrm{r}$ onlijing verband (U) verondersteld

1

II

\begin{tabular}{|cc|}
\hline 1 & II \\
\hline & instrumentele \\
objektiewe & binding aan de \\
of subjektieve & werkituatile \\
verzulim- & (werzuita- \\
noodzaak & behoefte)
\end{tabular}

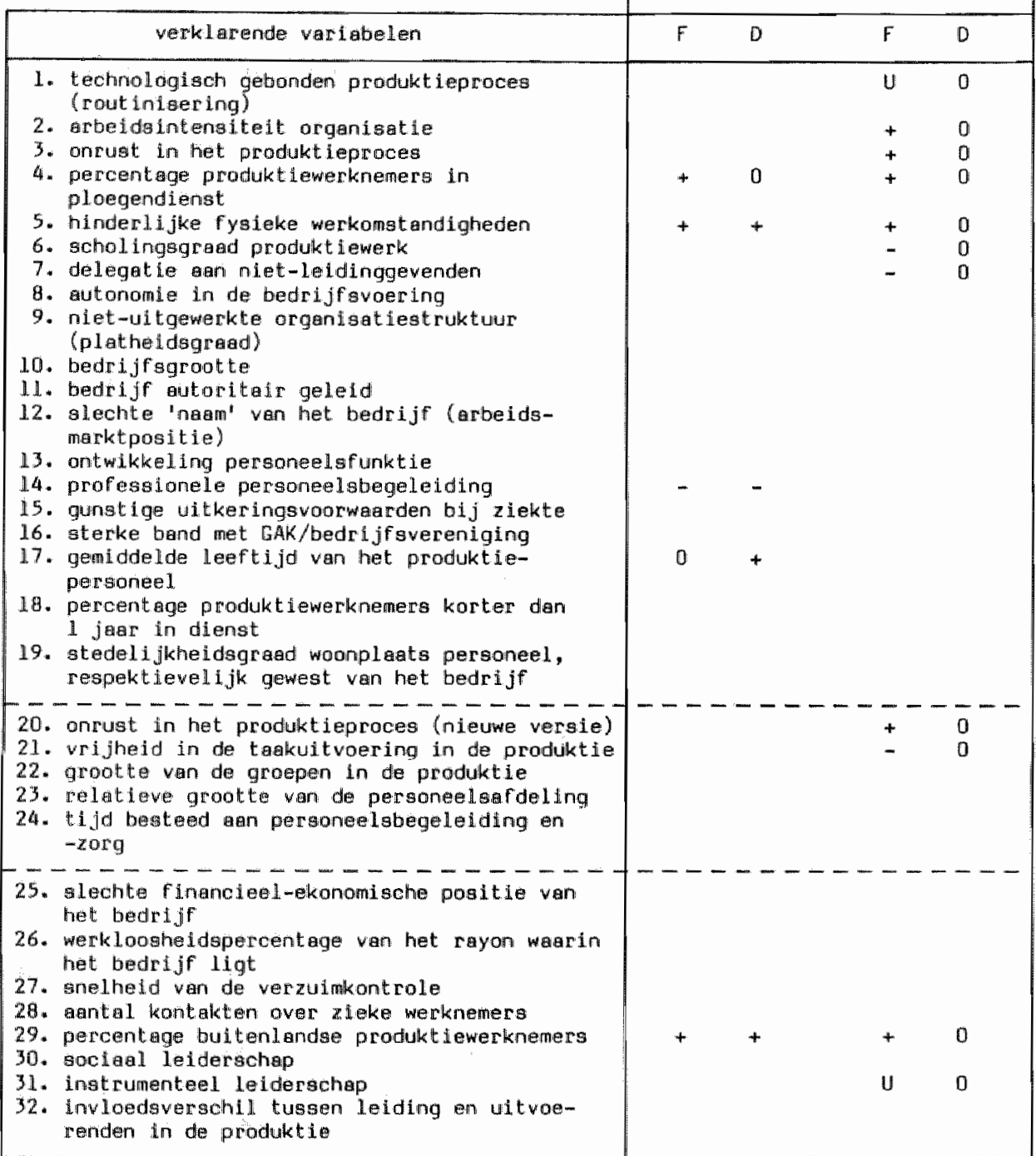

* beite begrippen (IW en VI) werder door Philipsen samengevoegd, omdat ze door de$z e l f$ de variabelen te operetionaliseren $z i j n$

Bron met betrakking tot de wariabelen 1 t/m 19: Philipsen (1969, p. 147-153) 


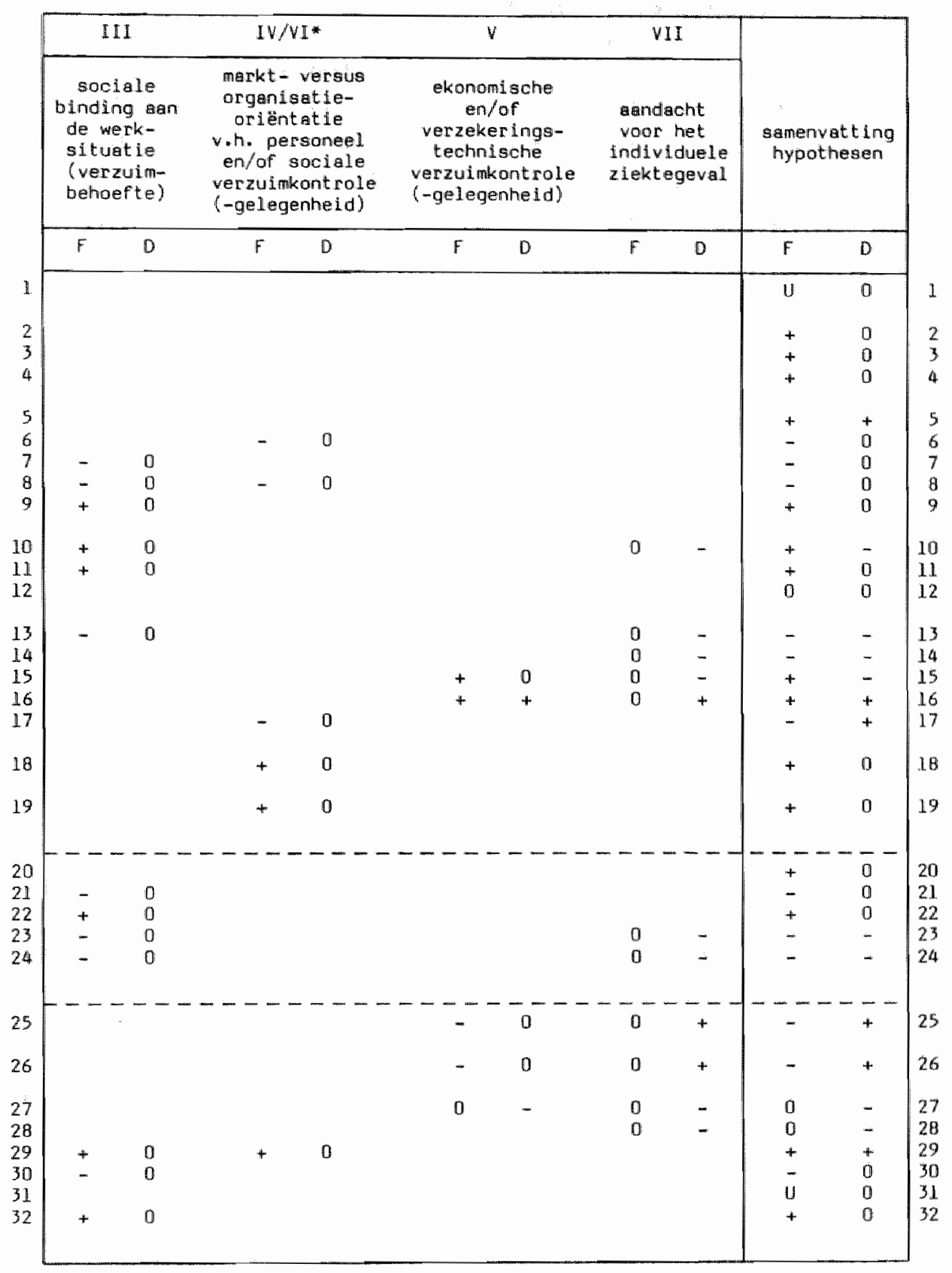


zou men kunnen zeggen). Verzuimnoodzaak kan zowel frekwentie- als duurverhogend werken, was de gedachte hierbij.

Ten tweede werd door Philipsen een individu-gebonden begrip aan de orgenisatie- en gezondheidsbegrippen toegevoegd. Het betreft. de warrdenoriëntatie van de gemiddelde werknemer, gespecificeerd in het theoretisch schema als markt- respektievelijk organisatieoriëntatie, waarbij de laatste soort meer met een lagere verzuimfrekwentie geacht werd samen te gaan (kolom IV). Markt-/organisatie-oriëntatie (IV) is door Philipsen samengevoegd met sociale verzuimkontrole (VI) ondat beide begrippen door dezelfde variabelen geoperationaliseerd bleken te kunnen worden.

Ten derde heeft Philipsen de aandacht voor het individuele ziektegeval van de kant van de organisatie, als verzuimduur-beperkende aktiviteit aan de andere koncepten toegevoegd (zie kolom VII).

Met negentien variabelen operationaliseerde Philipsen bovenomschreven hoofdkoncepten (zie variabele 1 tot en met 19, tabel 5.1).

Voor een goed begrip van tabel 5.1 kan nog vermeld worden dat de detailhypothesen, die met een + , - of $0 \mathrm{zijn}$ aangegeven, door Philipsen (1969, p. 149) bedoeld zijn als partiële relaties, dat wil zeggen dat bij het veronderstelde effekt van een variabele de werking van de andere variabelen uitgeschakeld geacht is. Bij de toegevoegde variabelen 20 tot en met 32 is getracht deze werkwijze ook zoveel mogelijk te volgen.

Een kanttekening bij het theoretisch schema met de hypothesen dient nog gemaakt te worden. In de opvatting van Philipsen werd van vijf van de zes hoofdkoncepten verwacht dat ze de frekwentie zouden beïnvloeden (aandacht voor het individuele ziektegeval is de uitzondering) en van drie van de zes hoofdkoncepten werd vecondersteld dat ze met de duur in verbinding zouden staan (binding en de individuele oriëntatie/sociale kontrole zijn hier de uitzonderingen). Dp basis van empirisch onderzoek zou wel iets af te dingen zijn op deze gedachtengang. Zo werden in de feitelijke resultaten van het anderzoek van Philipsen zelf, acht van de 38 detailhypothesen (negentien variabelen $\times$ frekwentie en duur) niet bevestigd. De niet-bevestigde detailhypothesen betroffen vooral degene die geacht werden sociale en instrumentele binding te indiceren. Met dit punt zal straks bij de toevoeging van de variabelen voor de vervolganalyse (hoofdstuk 7) rekening gehouden wor- 
den. Het bovenstaande is echter geen aanleiding geweest om aan de oorspronkelijke hypothesen en de gedachtengang daarachter te gaan sleutelen (alleen bij variabele $12 \mathrm{zal}$ alsnog een hypothese geformuleerd worden, waar deze eerst ontbrak). Dit geschiedde in verband met de overzichtelijkheid van het betoog.

De gedachtengang van Philipsen zal hier dus geacepteerd worden als uitgangspunt en in het resultatengedeelte van de replikatieanalyse (hoofdstuk 6) zal op de verhouding tussen de oorspronkelijke hypothesen en de gevonden resultaten teruggekomen worden. Andere onderzoeksresultaten kunnen dan tevens in de diskussie betrokken warden.

Wat hier nu resteert is de argumentatie voor het opnemen in dit onderzoek van de variabelen 20 tot en met 32 . Deze dertien bestaan uit vijf vervangende $(20-24)$ en acht taegevoegde variabelen $(25-32)$. Wat betreft de eerste groep $z i j$ vermeld dat in de hoofdstukken 5 en 6 de negentien door Philipsen gebruikte variabelen op hun betrouwbaarheid en validiteit bekeken zullen worden en dat daarbij de konklusie zal zijn dat vijf ervan $(1,3,9,13$ en 14) om uiteenlopende redenen revisie behoeven. Deze revisie is getracht tot stand te brengen door opneming van de nummers 20 tot en met 24.

De toevoeging van de groep variabelen 25 tot en met 32 heeft - in het kort - de volgende vier achtergronden.

1. In het theoretisch schema van Philipsen valt het op dat de begrippen verzuimgelegenheid en verzuimnoodzaak het minst sterk zijn vertegenwoordigd in de konkrete operationalisering door middel van de negentien variabelen. Vooral een wat omvangrijker indicering van verzuimgelegenheid lijkt in deze tijd van ontslagen en afvloeiingen - die als gelegenheidbeperkend opgevat kunnen worden - op zijn plaats. Door de toevoeging van een drietal variabelen is getracht daarin te voorzien. Deze zijn de financieel-ekonomische positie van het bedrijf (25), het werkloosheidspercentage van het rayon waarin het bedrijf ligt (26) en de snelheid van de verzuimkontrole (27).

2. Een variabele werd voorts toegevoegd ter indicering van de aandacht voor het individuele ziektegeval. Het gaat hier om het aantal kontakten tussen de bedrijfsleider, de personeelsefdeling en de verzekeringsarts over zieke werknemers (28). 
3. Verder werd van variabele 29 (percentage buitenlandse produktiewerknemers) aangenomen dat deze een indikatie zou zijn van de afwezigheidsnoodzaak. Uit onderzoek (zie paragraaf 5.4) is namelijk gebleken dat buitenlandse werknemers onder meer door ziekmakende stress-situaties binnen en buiten het werk, een grotere kans op afwezigheid hebben den hun Nederlandse kallega's. Wel dient hierbij uitdrukkelijk opgemerkt te worden dat het als hager veronderstelde verzuim van buitenlandse werknemers in het theoretisch model óók afhangt van de geringere binding aan de werksituatie en de als geringer veronderstelde organisatie-oriëntatie.

4. Eerder werd reeds opgemerkt dat in het onderzoek van Philipsen vooral de hypothesen met betrekking tot de bindingsvariabelen slechts beperkt bevestigd werden. Dit is er aanleiding toe geweest deze kwestie nog eens wat meer in detail onder de loupe te nemen. Daarom werden tenslotte nog drie variabelen opgenomen ter indicering van de sociale en instrumentele binding aan de werksituatie. Het betreft de mate van sociaal leiderschap (30), de mate van instrumenteel leiderschap (31) en de invloedsverschillen tussen produktieleiding en uitvoerenden (32).

De hypothesen die geformuleerd $z i j$ n bij de variabelen 20 tot en met 32 zullen in paragraaf 5.4 toegelicht worden bij de gedetailleerde beschrijuing ervan.

5.2 Beschrijuing van de negentien verklarende variabelen uit de replikatie-analyse

In deze paragraf zullen de negentien verklarende variabelen uit de replikatie-analyse achtereenvolgens behandeld worden. Daarbij zal steeds vermeld worden hoe de gegevens verzameld zijn (via de bedrijfsleider of de personeelschef, of via dokumentatie van het bedrijf zelf of elders) en welke de subvariabelen zijn.

Indien daarover gegevens beschikbar zijin zal ook op de betrouwbaarheid ingegaan worden. Over de validiteit van de variabelen kunnen pas uitspraken gedaan worden indien ze gerelateerd zijn aan de andere onafhankelijke variabelen en aan de afhankelijke variabele (verzuim). Daartoe zal in hoofdstuk 6 gelegenheid bestaan. 
De door Phllipsen geformuleerde hypothesen zullen steeds overgemomen worden. Dit betekent dat geen nieuwe argumentatie aangedragen zal worden voor de hypothesen. Er wardt verwezen naar de publikatie van Philipsen (1969).

Verder zij nog opgemerkt dat alleen daar war dit expliciet wordt vermeld, afgeweken is van de operationalisering van Philipsen.

Tenslotte: voor inzicht in de variabelen zijn de gemiddelden en spreidingen van belang. Deze zullen in paragraaf 5.3 gedetailleerd weergegeven worden. De gemiddelden en spreiding van de subvariabelen treft men in bijlage I aan.

\section{Variabele 1: Technologisch gebonden produktieproces (routinise- ring)}

Deze variabele bestaat uit twee subvariabelen. Voor de eerste daarvan werd, in navolging van Philipsen, aan de bedrijfsleider gevraagd aan te geven of het produktieproces te typeren is als enkelstuksproduktie, serieproduktie, massaproduktie of procesproduktie.

Een punt hierbij is dat Philipsen in zijn onderzoek massa- en procesproduktie in volgorde amkeerde, hetgeen niet in overeenstemming is met de technologie-indeling van Woodward (1965) en van anderen. Philipsen was er echter op uit een index voor de mate van routinisering te vinden, zodat zijn aanpak toch gevolgd zal worden. Dus enkelstuksproduktie krijgt score 1 , serieproduktie score 2, procesproduktie score 3 en massaproduktie score 4. De andere subvariabele werd zowel aan de bedrijfsleider (BL) als aan de personeelschef (PZ) voorgelegd. Het betrof de vraag naar de mate van $v r i j h e i d$ in werktempo en werkonderbrekingen in de produktie-afdelingen (zeer veel, tamelijk veel, enige, weinig of geen vrijheid, respektievelijk score $1,2,3,4)$. De scores ven beide respondenten werden opgeteld en door twee gedeeld. Za werd een op hele getallen afgeronde score verkregen, die minimaal 1 en maximael 4 kan bedragen.

De total-score per bedrijf kon derhalve minimaal 2 en maximaal $B$ bedragen ( $B=$ massaproduktie met weinig of geen vrijheid in werktempo en werkonderbrekingen).

De interkorrelaties tussen de items zijn als volgt: 
1. produktieprocestype (enkelstuks-massa;

2. vríjheid in werktempo/-onderbrekingen

2. vrijheid in werktempo/-onderbrekingen

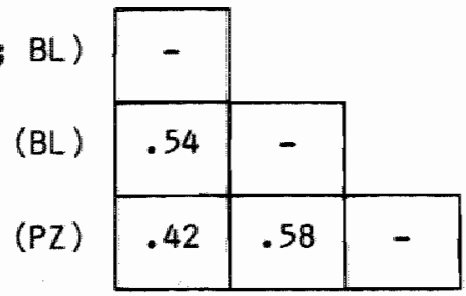

$1(\mathrm{BL}) \quad 2(\mathrm{BL}) \quad 2(\mathrm{PZ})$

Men ziet uit deze interkorrelaties dat beide respondenten behoorlijk overeenstemden in hun mening met betrekking tot de vrijheid in werktempo, etcetera $(\mathrm{r}=.58)$.

Dok door middel van variantie-analyse is getracht meer inzicht in de betrouwbaarheid van deze subvariabele te verkrijgen. Daarbij bleek dat de waarde ervan sterk bepaald werd door de verschillen tussen de bedrijven $(p<.0001)$ en bijna niet door de verschillen tussen beide respondenten $(p=.55)$. Dit betekent een belangrijke ondersteuning voor de betrouwbaarheid van de subvariabele vrijheid.

De korrelatie tussen produktieprocestype en de gemiddelde score van belde respondenten met betrekking tot vrijheid is $r=.57$. Dus bij enkelstuksproduktie is de grootste en bij massaproduktie de geringste mate van vrijheid in werktempo en werkonderbreking. Philipsen vond hier een korrelatie van .64 tussen beide deelvariabelen.

Uit tabel 5.2 valt te konkluderen dat het verband tussen beide deelvariabelen - op deze wijze gescoord - tamelijk lineair is.

Tabel 5.2. De verdelling van de bedrijwen over de twee subvariabelan van varlabele 1

\begin{tabular}{|c|c|c|c|c|c|}
\hline \multirow{2}{*}{$\begin{array}{l}\text { produkt je- } \\
\text { procestype }\end{array}$} & \multicolumn{4}{|c|}{ vrijheld in werkttempio en werkanderbrekingen } & \multirow{2}{*}{ totanl } \\
\hline & $\begin{array}{l}\text { zeer weel } \\
\text { vidjheid }\end{array}$ & $\begin{array}{l}\text { tamel ijk veel } \\
\text { wrijheid }\end{array}$ & $\begin{array}{c}\text { en Lge } \\
\text { vrijhed }\end{array}$ & $\begin{array}{l}\text { welmig of geen } \\
\text { wrijheid }\end{array}$ & \\
\hline arke 1 gt wik & 1 & $\theta$ & 0 & 0 & 9 \\
\hline selie & 2 & 8 & 26 & $\mathrm{O}$ & 36 \\
\hline proces & 0 & 7 & 10 & 1 & 18 \\
\hline $\operatorname{masse}$ & 0 & 1 & 11 & 10 & 22 \\
\hline total & 3 & 24 & 47 & 11 & 85 \\
\hline
\end{tabular}


Massaproduktie gaat gepaard met de minste vrijheid, enkelstuksproduktie met de meeste en serie- en procesproduktie zitten daar tussenin. Overigens is het goed op te merken dat we hier te maken hebben met twee nominale schalen waaraan ranggetallen zijn toegekend, zodat men aan lineaire of kromlijnige verbanden alleen maar betrekkelijke betekenis mag toekennen.

Uit later te presenteren gegevens zal blijken dat beide deelvariabelen ook als aparte hoofdvariabelen opgevoerd kunnen worden. Hierop zal in de beschrijuing van de variabelen 20 en 21 verder ingegaan worden. Variabele $1 \mathrm{zal}$ dan ook alleen in de replikatieanalyse opgenomen worden en in latere analyses vervangen worden door de variabelen 20 en 21 .

\section{Variabele 2: Arbeidsintensiteit van de organisatie}

Dit dokumentatiegegeven is verkregen via de afdeling Personeelszaken van de bedrijuen. Het betreft het percentage dat de arbeidskosten (lonen, salarissen, sociale verzekeringen) van de totale kosten van het bedrijf vormen.

De totale kosten van het bedrijf werden gezien als de verbruikskosten (grondstoffen, halffabrikaten, brandstoffen, emballage, etcetera) plus de bruto toegevoegde waarde (afschrijvingen, 10nen, sociale lasten, winsten, rente, huren, etcetera).

Door de meerdere interpretatie-mogelijkheden bij de vaststelling van de totale en de arbeidskosten is het mogelijk dat de betrouwbaarheid van het gegeven niet optimaal is. Een drietal bedrijven was niet in staat het arbeidskostenpercentage te leveren. In die gevallen is het via het CBS verkregen bedrijfstak-gemiddelde als vervangende warde genomen.

\section{Variabele 3: Onrust in het produktieproces}

Deze variabele is tot stand gekomen door het sommeren van drie deelvragen, voorgelegd aan de bedrijfsleider. Het betreft:

1. de mate van storingen in het produktieproces door te late toelevering of onvoldoende kwaliteit van grondstoffen en dergelijke (nooit, enigermate, in sterke mate, respektieveli jk score $0,1,2)$;

2. de vraag of het bedrijf geheel uit voorraad, deels uit voorraad en deels op bestelling, of geheel op bestelling levert (respektievelijk scores 0, 1, 2); 
3. de mate van konkurrentie welke het bedrijf bij de afzet ondervindt (geen, enige, sterke, respektievelijk 0, 1, 2).

In dit onderzoek bleek de derde deelvariabele - de mate van konkurrentie - een geringe spreiding te vertomen. In 70 procent van de bedrijven waren de bedrijfsleiders namelijk van mening dat de konkurrentie sterk was (score 2). De spreiding in de eerste twee deelvariabelen was bevredigend (zie Bijlage I).

De interkorrelaties zijn als volgt:

1. mate van storingen

2. levering op voorraad, respektievelijk bestelling

3. mate van konkurrentie

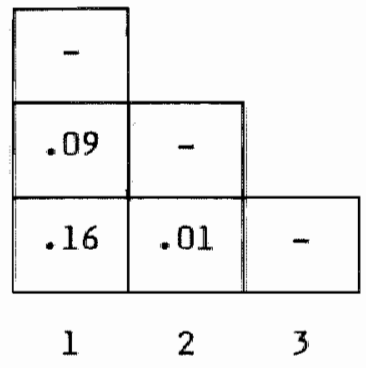

De betrouwbaarheidskoëfficiënt Cronbach's Alpha is hier slechts 0.21. De variabele wordt dus gekenmerkt door weinig interne konsistentie. Philipsen vond ook een lage interne konsistentie (volgens de koëfficiënt van Hoyt, van .43) en meende dat de lage waarde vermoedelijk niet aan de beantwoording van de respondenten te wijten was, maar een gevolg was van de geringe samenhang tussen de subvariabelen in de werkelijkheid. Hij zag er geen reden in de variabele te elimineren.

Toch zal in de vervolganalyse voor variabele 3 variabele 20 als alternatief gebruikt worden (zie hiervoor p. 109-112).

\section{Variabele 4: Percentage produktiewerknemers in ploegendienst}

De personeelsafdeling van de bedrijven heeft berekend hoeveel mannelijke produktiemedewerkers in ploegendienst werkzaam zijn (ongeacht de soort ploegendienst). Dit aantal is uitgedrukt in procenten van het totaal aantal produktiewerknemers.

Het percentage ploegendienst-werknemers per bedrijf kon in de praktijk van 0 tot 100 procent uiteenlopen. De verdeling van de mannelijke produktiewerknemers van alle 85 bedrijven over dag- en ploegendiensten was als volgt: 
- dagdienst

- twee-ploegendienst

- drie-ploegendienst

- anderssoortige diensten
55.9 procent

14.9 procent

21.4 procent

7.8 procent

\section{totaal}

100.0 procent

In dit onderzoek werkt dus ruim 44 procent van de mannelijke produktiewerknemers in ploegendienst. Voor de gehele Nederlandse industrie (produktie plus administratie) wordt in de literatuur soms wel een percentage van 20 genoemd.

De betrouwbaarheid van dit gegeven zal waarschijnlijk groot zijn, omdat het om een vrij simpel kenmerk gaat dat zonder veel moeite uit de personeelsadministratie te destilleren valt.

\section{Variabele 5: Hinderlijke fysieke werkomstandigheden}

Zowel aan de bedrijfsleider als aan de personeelschef is gevraagd aan te geven in welke mate men in de produktie-afdelingen hinder ondervindt van een achttal aspekten van werkomstandigheden (geen, weinig, enige, veel, zeer veel; score 1, 2, 3, 4, en 5). Het ging daarbij om warmtebelasting, temperatuurswisselingen, tocht, gebrekkige luchtverversing, zwaarte van het werk in lichamelijk opzicht, gevaarlijke stoffen, gassen en/of dampen, gebrek aan netheid en ongevallenrisiko. Per aspekt werden de scores van beide respondenten gesommeerd en tenslotte werden alle acht aspekten gesommeerd (de theoretische variatiebreedte is dus 16-80). De interkorrelaties tussen de acht aspekten (de somscores van belde respondenten) worden op de volgende pagina weergegeven.

Op de diagonaal treft men de korrelaties aan tussen beide respondenten met betrekking tot de betreffende subvariabele. Dit zijn dus indikaties van betrouwbarheid per subvariabele.

De korrelatie tussen beide respondenten net betrekking tat de som van alle acht aspekten (de totale variabele) bedraagt $r=.52$. Dok door middel van tweevoudige variantie-analyse is de betrouwbaarheid van de acht aspekten van fysieke werkomstandigheden bekeken. Daaruit bleek dat de scores op de acht verschillende aspekten van werkomstandigheden sterk signifikant verschillen tussen de bedrijuen (in alle gevallen $p \leqslant .002$; zie tabel 5.3 ). Voorts blijkt uit de rechter kolom ven de tabel dat de persom neelschefs ten aanzien van warmtebelasting en zwaarte van het werk systematisch $(p<.05)$ kritischer oordeelden dan de bedrijfsleiders. 
1. warmtebelasting

2. temperatuurswisselingen

3. tocht

4. gebrekkige luchtverversing

5. zwaarte van het werk in lichamelijk opzicht

6. gevaarlijke stoffen etcetera

7. gebrek aan netheid

8. ongevallenrisiko

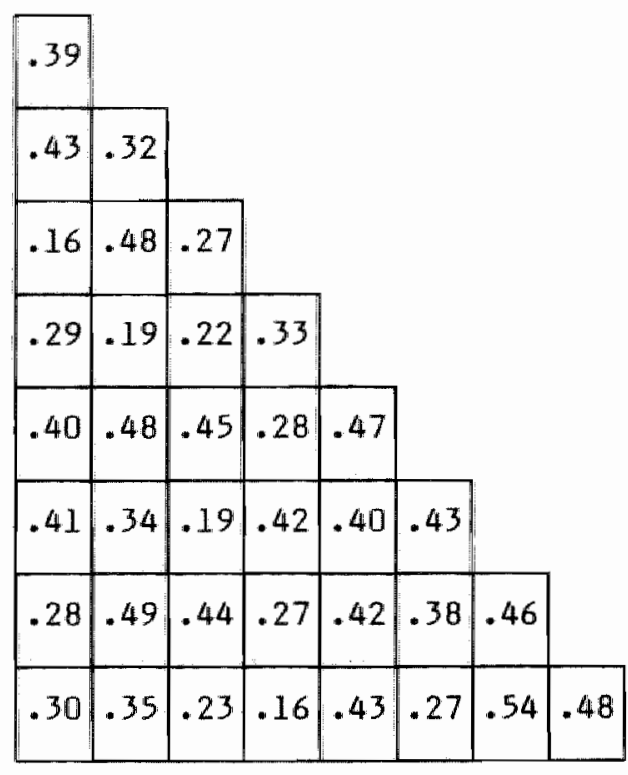

$\begin{array}{llllllll}1 & 2 & 3 & 4 & 5 & 6 & 7 & 8\end{array}$

Tabel 5.3 De gemiddelde scares van beide respondenten op de subvariabelen van variabele 5 en de sigmifikantie van de verschillen tussen de bedrijven en tussen de respondenten

\begin{tabular}{|c|c|c|c|c|}
\hline subvariabelen & $\begin{array}{l}\text { geniddelde } \\
\text { score van de } \\
\text { bedrijfs- } \\
\text { leiders }\end{array}$ & $\begin{array}{l}\text { gemiddelde } \\
\text { score van de } \\
\text { personeels- } \\
\text { chefs }\end{array}$ & $\begin{array}{l}\text { signifikantie } \\
\text { van de ver- } \\
\text { schillen tussen } \\
\text { de bedrijven }\end{array}$ & $\begin{array}{l}\text { signifikantie } \\
\text { van de ver- } \\
\text { schillen tussen } \\
\text { de respondenten }\end{array}$ \\
\hline 1 warmt ebelasting & 2.02 & 2.22 & .0002 & .03 \\
\hline $\begin{array}{l}2 \text { temperatuurwisse- } \\
\text { lingen }\end{array}$ & 2.02 & 2.19 & .002 & .07 \\
\hline 3 tocht & 2.21 & 2.27 & .006 & .58 \\
\hline $\begin{array}{l}4 \text { gebrekkige luoht- } \\
\text { verwergling }\end{array}$ & 1.81 & 1.91 & .001 & .32 \\
\hline $\begin{array}{l}\text { 5. zararte van het } \\
\text { werk in lichameli jk } \\
\text { opzlicht }\end{array}$ & 2.35 & 2.61 & .00002 & .002 \\
\hline $\begin{array}{l}6 \text { gevear lijke stoffen, } \\
\text { gessen, dampen }\end{array}$ & 1,81 & 1.95 & .00005 & .11 \\
\hline 7 gebrek ann netheld & 2.08 & 2.14 & .00004 & .52 \\
\hline B ongevallentisiko & 2.25 & 2.29 & .00002 & .55 \\
\hline totalscore & 16.57 & 17.59 & . 000004 & .01 \\
\hline
\end{tabular}


Ten aanzien van de zes andere aspekten verschillen beide respondenten niet systematisch van mening. Dit betekent dat de bedrijfsleiders en de personeelschefs met betrekking tot de laatste zes aspekten hetzelf de deel van de antwoordschaal gebruikten om hun mening tot uitdrukking te brengen, terwijl bij de eerder genoemde twee aspekten de personeelschefs meer het 'kritische" deel van de antwoordschaal gebruikten dan de bedrijfsleiders. Het laatste wil overigens niet zeggen dat de bejde respondenten het over de situatie in hun bedrijven niet signifikant eens zouden zijn. Dat is wel het geval, zoals hierboven al werd vermeld.

Met de totaal-score voor hinderlijke fysieke werkomstandighedem doet zich hetzelfde voor: sterk signifikante verschillen tussen de bedrijuen, terwijl de personeelschefs systematisch iets negatiever scoren dan de bedrijfsleiders.

Kortom, er is alle anleiding om vertrouwen te hebben in de betrouwbarheid van de meting betreffende de fysieke werkomstandigheden. Een dergelijke konklusie trok Philipsen trouwens ook uit zijn materiaal (interne konsistentie van de zestien antwoorden van de twee respondenten bedroeg in zijn onderzoek volgens de koefficiënt van Hoyt .82).

\section{Variabele 6: Scholingsgraad van het produktiewerk}

Elk bedrijf is gevraagd van het produktiepersoneel aan te geven hoeveel werknemers op 1 januari 1981 ongeschoold, geoefend en geschoold werk deden. Ongeschoold werk werd gedefinieerd als werk dat géén vooropleiding en weinig of geen oefening vraagt. Geoefend werk was werk dat een oefening van enkele weken tot enkele maanden vrasgt, maar geen vooropleiding. Geschoold werk werd als werk gezlen warvoor een vooropleiding en/of langdurige oefening in het bedrijf nodig is. De toegekende warden aan deze drie kategorieën waren respektievelijk 1,2 en 3 . Door percentering van de drie kategorieën en vermenigvuldiging met de respektievelijke waarde kon een bedrijfsscore voor de gemiddelde scholingsgraad van het produktiewerk berekend worden.

Voor de personeelsafdelingen was, blijkens navraag, de instruktie bij de vraag duidelijk geweest, zodat aangenomen mag worden dat de betrouwbaarheid van de variabele bevredigend is.

Voor alle 85 bedrijven te zamen was het produktiepersoneel als volgt over de drie kategorieën verdeeld: 
- werknemers in ongeschoold werk

- werknemers in geoefend werk

- werknemers in geschoold werk

totaal
21.0 procent

37.6 procent

41.4 procent

100.0 procent

Tabel 5.4 De twee vragenlijsten om delegatie van bevogdheden door 'de gemiddelde baas' abr zijn ondergeschikten mee te meten (varlabele 7 )

I.

( ) Hij heeft zijn ondergeschikten de bevoegdheid gegeven, om hum taken uit te voeren op de wijze die zij zelf geschikt achten.

( ) Zijn ondergeschikten dragen de volle verantwoordelijkheid, mas hij behoudt zelf het recht on beleidsbeslissingen goed of af te keuren.

() Zijn ondergeschikten hebben de bevoeguheid gekregen, am beslissingen te nemen met betrekking tot voorkomende problemen, maar moeten hem op de hoogte houden wan belangri jke zaken.

() Zijin andergeschikten hebben de bevoegdheid on alle routinezaken te behandelen die zich dagellijks voordioen.

) Zi.jn ondergeschikten kunnen de meeste cout inezaken zelf behandelen.

) Veel van de verantwoordelijkheden van de baas kumen niet aan zijn ondergeschikten toevert rouwd worder.

() Zijn andergeschikten hebbem geen werkelijke bevolegdheden om akti ie te ondernemen, maer $z i j$ doen anbevelingen asn hem om beparlde alkties te ondernemen.

Hij geeft zijn ondergeschikten gedetaileerde opdrachten, welke zilj precies volgens voorschrift moeten uitvoeren en wasbij $z i j$ hem moeten raadplegen als ze twijfelen.

II

Hij meemt alleen de beslissingen als hij geraadpleegd wordt in ongewone omstandigheden; hij heeft $z i j n$ ondergeschikten dus een grote mate van invloed en verantwoordelijkheid gegeven bij het nemen van beslissingen.

Hij heeft de volledige beslissingsbevoegdheid gedelegeerd aan zijn ondergeachikten, behalve het recht an het beleid en de algemene wijze van werken te bepallen.

) Hid duldt zijn ondergeschikten in grote lijnen aen, wat hij gedaen wil hebben. Het is hum elgen verantwoordelijkheld om te beslissen hoe het uitgevoerd moet worden en en voor te zorgen dat het ook gebeurt.

) HII heeft aan $z \mathbb{H} j n$ ondergeschikter de bevoegdheid gedelegeerd om alle dage1ijkse rout inematige beslisingen te nemen.

). Hij neemt de meeste beslissingen die binnen zijn bewoegdheid liggen zelf, hoewel zijn ondergeschikten een aanzienlijke verantwoordelijkheid op zich nemen voor beslissingen in routinezaken, wasrover het beleid en de wijze van werken duidelijk vastgelegd is.

Hij houdt vrij strak toezicht op zijn ondergeschikten wat betreft hun bevoeg ghe den.

Hij neent alle belangrijke beslissingen die binnen zijin bevoegdheden liggen. Zijn ondergeschikten zijn werantwoordelijk als het gaat on beslissingen in minder belangrijke zaken.

Hij vindt het niet aanbevelingswardig om bevogdherden te delegeren aen zijn ondergeschikten. 


\section{Variabele 7: Delegatie oan niet-leidinggevenden}

Delegatie van bevoegdheden van 'bazen' in de produktie aan hun ondergeschikten werd gemeten met de hieronder weergegeven twee vragenlijsten (tabel 5.4). Deze twee lijsten zijn een vertaling van 1 ijjst III en VI van Stogdill en Shartle (1955, p. 42-43) betreffende delegatie van verantwoordelijkheden aan niet-leidinggevenden. De oorspronkelijke bron is hier gebruikt omdat Philipsen (1969) deze informatie niet vermeldde.

Beide lijsten bevatten acht uitspraken over de relatie baas - ondergeschikte met betrekking tot delegatie. De lijsten ziljn - uit uitvoerig onderzoek - ontwikkeld als Thurstone-schalen, hetgeen wil zeggen dat de uitspraken in volgorde staan: de bovenste uitspraak indiceert de meeste en de onderste uitspraak de minste delegatie. Dit werd uiteraard niet aan de respondenten medegedeeld. Zowel de bedrijfsleider als de personeelschef werden de twee vragenlijsten voorgelegd. Hun werd gevraagd in elke lijst de twee uitspraken aan te kruisen die het best de feitelijke relatie tussen 'de gemiddelde baas' in de produktie-afdelingen en zijn ondergeschikten beschrijuen. De acht items in de twee lijsten werden na invulling genummerd van 8 tot en met 1 , wararbij de score 8 de meeste delegatie angaf. Elke respondent kon derhalve per lijst een minimale score van 3 en een maximale score van 15 noteren (en in de twee lijsten te zamen minimaal 6 en maximaal 30). De scores van beide funktionarissen werden vervolgens opgeteld, door acht (het totaal aantal, door beide respondenten te zamen, aangekruiste items) gedeeld en naar boven afgerond op hele getallen, waardoor de theoretische variatiebreedte tussen 2 en 8 kwam te liggen.

De interkorrelaties tussen de twee instrumenten zijn als volgt:

1. eerste delegatielijst (BL)

eerste delegatielijst ( $P Z)$

2. tweede delegatielijst (BL)

tweede delegatielijst $(P Z)$

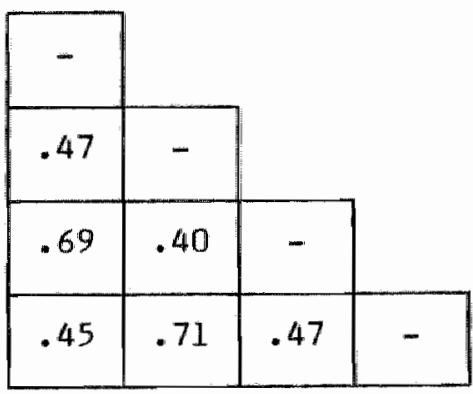

$1(\mathrm{BL}) 1(\mathrm{PZ}) 2(\mathrm{BL}) 2(\mathrm{PZ})$ 
Men zlet dat beide respandenten het zowel ten aanzien van de eerste als de tweede delegatielijat redelijk met elkaar eens zijn (in beide gevallen is $r=.47$ ). Bovendien blijkt dat beide lijsten zowel door de bedrijfsleider als door de personeelschef op sterk gelijke wijze werden beoordeeld ( $r=.69$ en .71 ).

De korrelatie tussen de somscores op beide lijsten van de bedrijfsleider en de personeelschef bedraagt $r=.52$, hetgeen aanmerkelijk hoger is den Philipsen vond $(r=.10)$.

Ook deze variabele is nog eens door middel van tweevoudige variantie-analyse nader bekeken. De gemiddelde scores op zowel de bovenste als de onderste lijst bleken zeer signifikant te verschillen tussen de bedrijven $(p<.0001)$. Bovendien verschilden de bedrijfsleider en de personeelschef op de bovenste lijst niet systematisch van elkear $(\rho=.20)$ terwijl op de onderste lijst de personeelschef systematisch kritischer oordeelde dan de bedrijfsleider $(p=.02)$. De betrouwbarheid van de delegatielijsten lijkt derhalve voldoende gegarandeerd te zijn.

\section{Variabele 8: Autonomie in de bedrijfsvoering}

Om te komen tot deze variabele werden de volgende drie objektieve dokumentatiegegevens (verkregen via de bedrijfsleider), die geacht worden de autonomie in de bedrijfsvoering te bepalen, gesommeerd:

1. de rechtsvorm van het bedrijf: naamloze vennootschap (score 1), besloten vennootschap (3) en andere rechtsvorm (2);

2. famillebedrijf: nee (score 1), tot voor kort nog wel of nog gledeeltelijk wel (2) en ja (3);

3. mate van zelfstandigheid: niet zelfstandig en/of geen eigen rechtspersoonlijkheid (score 1 ), zelfstandig, maar wel gelieerd met een ander bedrijf of concern (2) en geheel zelfstandig (3).

De beantwoording van de derde vraag bleek soms tot problemen te leiden, als het ging on een werkmaatschappij, een divisie of een ander bedrijfsonderdeel, dat bij sominge aspecten van het beleid zelfstandig kon optreden en bij andere niet. Meestal werd den tot score 2 besloten. De twee andere gegevens leverden geen enkel probleem op.

De korrelaties tussen de drie subvariabelen zijn als volgt: 


\section{1. rechtsvorm}

2. familiebedrijf

3. zelfstandigheid

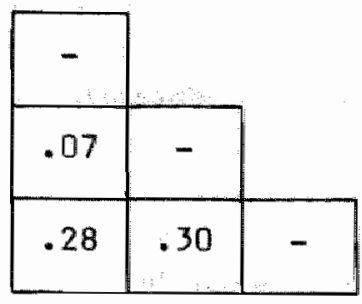

1

2

Cronbach's Alpha voor deze drie subvariabelen is 0.44 . Ze vertonen dus geen al te sterke interne konsistentie, hetgeen bij Phi$\mathbb{1}$ ipsen meer het geval was (koëfficiënt van Hoyt van .63). De beperkte interne konsistentie is vooral te wijten aan het feit dat familiebedrijven in tegenstelling tot de verwachting net zo vaak besloten als open vennootschappen blijken te zijn. Bovendien is de spreiding van de variabele familiebedrijf nagal matig: er komen nog maar weinig familiebedrijven voor (zie Bijlage I).

\section{Variabele 9: Niet-uitgewerkte organisatiestruktuur (platheids- graed)}

Organisaties kunnen in hun vorm een uitgewerkte/steile indruk of een niet-uitgewerkte/platte indruk maken. In het eerste geval gaat het om relatief veel hiërarchische nivo's en kleine werkgroepen en in het tweede geval om weinig nivo's en grote werkgroepen.

Volgens Philipsen (1969, p. 123-124) zou de klassieke orgenisatietheorie de uitgewerkte/steile organisatievorm voorstaan, vanwege grotere doelmatigheid door specialisatie, centralisatie van beslissingen en gemakkelijker supervisie. Vooral van sociologische en sociaal-psychologische kant zou, volgens Philipsen, echter gewezen zijn op de voordelen van de platte organisatievorm. Volgens deze sociale wetenschappers zouden minder kansen op kommunikatiestoringen en 'close supervision' en meer kansen op de demokratische invloedsverdeling, initiatief van onderop en positieve arbeidsmotivatie, de effekten kunnen zijn van een platte organisatievorm. Toch meende Philipsen dat uitgewerkte/steile orgenisaties bevredigender werkverhoudingen en dus een lagere verzuimfrekwentie zouden hebben. Hij redeneerde dat uitgewerkte organisatievormen veel vaker het gevolg zouden $z i j n$ van bewust doordachte en geplande beleidsbeslissingen met kennis van mense- 
1ijke verhoudingen en dáárdoor bevredigender voor de organisatieleden. Bovendien meende $h l j$ dat de middelgrote organisaties uit zijn onderzoek voor hun 'funktioneringskracht" tussenlagen en ultgewerktheid (vertikalisering) juist nodig zouden hebben.

De mate van horizontaliteit of de platheidsgraad van de organisatie werd bepaald door een formule afkomstig van Blau en Scott (1963) en aangepast in vorm. Deze formule is:

platheldsgraad =
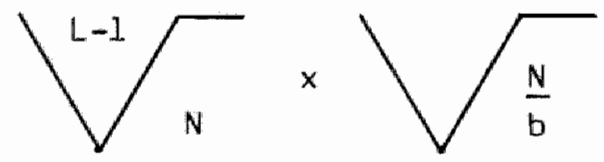

waarin $L$ het aantal hiërarchische lagen is, $\mathbb{N}$ het aantal uitvoerende produktiemedewerkers en b het aantal "bazen' (laagste leidinggevende nivo) is. De waarde van de formule is minimaal 1 en indiceert dan een zeer steile/uitgewerkte organisatievorm. Hoe groter de waarde, hoe platter of niet-uitgewerkter de organisatievorm.

De bepaling van het aantal nivo's (inclusief de nivo's van direktie en uitvoerenden) en het aantal uitvoerende produktiemedewerkers leverde tijdens het onderzoek weinig moeilijkheden op. De bepaling van het aantal leidinggevenden op het laagste nivo was echter minder gemakkelijk. Het minste probleem daarbij was dat het leagste leidinggevend nivo zeer verschillend betiteld werd: 'chef', 'baas', 'groepsleider', etcetera. Problematischer was of voorlieden al dan niet tot het laagste leidinggevend nivo gerekend behoorden te worden. Uiteindelijk is besloten - om redenen van eenduidigheid - om alle funktionarissen op het laagste leidinggevend nivo op te nemen (ongeacht hun betiteling) inclusief eventueel onder hen staande, al dan niet meewerkende, voorlieden. Dit werd wezenlijk van belang geacht, omdat de aanwezigheid van voorlieden toch altijd als achtergrond heeft om leidinggevende steun (in de zin van koördinatie en instruktie) te geven. De korrelaties tussen de drie aspekten die in de formule voorkomen, zijn als volgt: 
1. aantal hiërarchische nivo's

2. aantal niet-leidinggevende produktiemedewerkers

3. aantal leidinggevenden op het laagste nivo

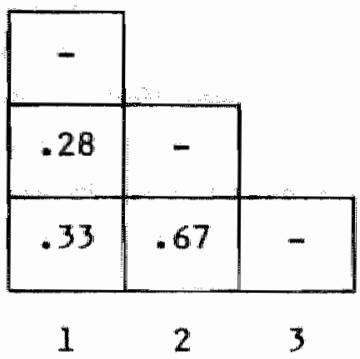

Berekening van de interne konsistentie van deze drie subvariabelen heeft uiteraerd geen zin.

Wel is nog nagegaan - nadat variabele 9 zelf was gekonstrueerd door welke van de drie subvariabelen variabele 9 het sterkst werd bepaald. De korrelaties van de hoofdvariabele met de drie subvariabelen waren:

- met het aantal hiërarchische nivo's $-.58$

- met het aantal niet-leidinggevende produkt iewerknemers

- met het eantal leidinggevenden op het laagste nivo

Men ziet dus dat de hoofdvariabele 9 het sterkst bepaald wordt door het aantal hiërarchische nivo's, en in mindere mate door het aantal niet-leidinggevende produktiewerknemers en het aantal leidinggevenden op het laagste nivo.

Ondat deze variabele door middel van een niet gemakkelijk interpreteerbare formule tot stand is gekomen, zal met variabele 22 (grootte van de groepen in de produktie ofwel de 'span of control' van de 'bazen') nagegaan worden of een eenvoudiger en inzichtelijker - hoewel niet volstrekt identieke - operationalisering tot gelijksoortige konklusies leidt.

\section{Variabele 10: Bedrijfagrootte}

Bedrijfsgrootte is gedefinieerd als de totale personeelsomvang (mannen en vrouwen, produktie en niet-produktie) van het bedri.jf. De peildatum voor dit gegeven was - evenals dit bij de andere dokumentatiegegevens het geval was - 1 januari 1981. Zaals reeds in hoofdstuk 3 vermeld werd, was dit gegeven een criterium om de steekproef van bedrijven te formeren. Alleen bedrijven met minimaal 100 en maximaal 1200 werknemers zouden in de steekproef opgenomen worden. Bij Philipsen waren deze cijfers respektievelijk 
100 en 1000. De uiteindelijk onderzochte bedrijven hadden een personeelsomvang van minimal 166 en maximaal 1571 personeelsleden. Twee bedrijven (het laatst bedoelde en een bedrijf wan 1268 werknemers) hadden meer personeel dan 1200; de rest bleef binnen de criteria. De gemiddelde bedrijfsomvang is in 1980/81 ook hager dan in 1964/65, namelijk 484 ten opzichte van 387 werknemers.

\section{Variabele 11: Bedrijf autoritair geleid}

De drie bij het onderzoek betrakken onderzoekers hadden de opdracht voor elke bedrijf - op basis van observaties, interviews en losse gesprekken - een schatting te geven van de mate waarin het bedrijf op demokratische of autoritaire wijze geleid werd. Philipsen refereerde bij deze begrippen, die als uiteinden van één schaal bedoeld zijn, enerzijds aan wederzijdse kommunikatie en anderzijds aan neerwaartse kommunikatie tussen boven- en ondergeschikten. Men zou ook kunnen spreken van het al dan niet bestaan van 'inspraak'.

De onderzoekers konden hun schatting uitdrukken op een vijfpuntsschaal met als antwoordmogelijkheden respektievelijk zeer demokratisch (score 1), demokratisch (2), tussen autoritair en demokratisch (3), autoritair (4) en zeer autoritair (5).

Ondanks het feit dat de onderzoekers van te voren afgesproken hadden welke observatiecriteria gehanteerd zouden worden (zoals de wijze van omgang van de respondenten met andere personeelsleden) bleken zij in een gering antal bedrijven niet goed in staat om een schatting te maken, omdat de observaties onvoldoende of tegenstrijdig waren. In die par gevallen is aan die bedrijven acore 3 toegekend. Dit doet maar weinig afbreuk aan de betrouwbaarheid van de variabele.

\section{Variabele 12: Slechte 'naan' van het bedrijf (arbeidamarktposi- tie)}

Deze variabele is geoperationaliseerd door twee vragen, die beide aan de bedrijfsleider werden gesteld.

De eerste vraag luidde: Hoe is de naam van uw bedrijf hier in de omgeving?, met els antwoordmagelijkheden: goed (score 1), gaat wel (2), matig (3) of niet zo best (4).

Als de naam aan de gunstige kant lag (score 1 of 2 ), werd gevraagd of dit dan de werving van personeel gemakkelijker maakte. De antwoordmogelijkheden waren hierbij: ja, gemakkelijker (score 
1), misschien (2) of nee, niet gemakkelijker (3).

Als, anderzijds, de naam aan de ongunstige kant lag (score 3 of 4), werd gevraagd of dit dan de werving van personeel moeilijker makkte. De antwoorden hierbij waren: nee, niet moeilijker (score 1), misschien (2) of ja, moeilijker (3).

Kombinatie van de scores op beide vragen kon derhalve leiden tot een somscore van minimaal 2 (goede naam, die het bedrijf in staat stelt gemakkelijker personeel te krijgen) tot maximaal 7 (slechte naam, die het bedrijf het moeilijker makt om personeel te krijgen.

De korrelatie tussen beide vragen bedroeg $\mathrm{r}=.43$.

De verdeling van de 85 bedrijven over beide variabelen was als volgt.

Tabiel 5.5 De verdeling van de bedrijven over de twee subvariabelen van variabele 12

\begin{tabular}{|c|c|c|c|c|}
\hline \multirow{2}{*}{ "magm" } & \multicolumn{3}{|c|}{ werving van personeel } & \multirow{2}{*}{ 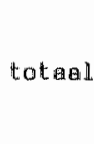 } \\
\hline & $\begin{array}{l}\text { makkel } 1 \text { jker/ } \\
\text { niet moeilijker }\end{array}$ & misschien & $\begin{array}{c}\text { niet makkelijker } \\
\text { moeilijker }\end{array}$ & \\
\hline goed & 17 & 14 & 9 & 40 \\
\hline geat wel & 4 & 16 & 12 & 32 \\
\hline matig & 0 & 4 & 6 & 10 \\
\hline silecht & 0 & 0 & 3 & 3 \\
\hline & 然 & $-=-$ & - & $-\infty-\infty$ \\
\hline tataal & 21 & 34 & 30 & 85 \\
\hline
\end{tabular}

Philipsen legde beide vragen niet alleen aan de bedrijfsleider maar ook aan de personeelschef voor en stelde een onderlinge samenhang van $r=.47$ tussen beide respondenten vast. Dat kan hier dus helaas niet gebeuren, ondat de vragen in 1980/81 abusievelijk alleen aan de bedrijfsleider en niet aan de personeelschef werden voorgelegd. Dver de betrouwbaarhejd van de variabele kan hier dan ook niet meer medegedeeld worden dan dat de bedrijfsleiders geen interpretatieproblemen hadden bij de beantwoording van de twee vragen.

Resteert nog de formulering van de veronderstelde relaties met de verzuimindikatoren. Philipsen formuleerde géén veronderstelling 
bij deze variabele ondat hij de 'naam' van het bedrijf niet als een geldige indikator kon beschouwen van de kansen op sociale binding, maar veeleer als een onduidelijke meting van de wervingskracht van het bedrijf.

Uit de kommentaren van de bedrijfsleiders bij de twee vragen valt de bevestiging te destilleren van de konklusie van Philipsen, dat de naam van het bedrijf niet in de eerste plats op het bedrijfsklimaat teruggevoerd werd, maar veel meer op fysieke werkomstandigheden, ploegendienst, loon en ook op de inhoud van het werk in brede zin.

Gezien het kommentaar van de respondenten mag men veronderstellen dat de naam van het bedrijf gekorreleerd is met variabelen als ploegendienst, fysieke werkomstandigheden, stijl van leidinggeven, etcetera. Tevens mag men er dan van uitgaan dat, indien deze varlabelen onder kontrole gehouden worden, de variabele 'naam' van het bedrijf geen verband meer vertoont met verzuim. De variabele 'naam' lijkt dus een soort verzamel-variabele van andere in het onderzoek voorkomende variabelen.

Het $1 \mathbf{i} \mathbf{j k t}$ dan ook logischer een niet-signifikant verband met verzuim te veronderstellen dan géén verbend te formuleren, zoals Philipsen deed. Deze veronderstelling is ook ingevoerd in het hypothetisch schema (tabel 5.1, p. 72-73) en is de enige afwijking van het schema van Philipsen. De hypothese wordt empirisch ondersteund door de resultaten van het onderzoek van Philipsen. $\mathrm{Hij}$ vond namelijk inderdaad niet-signifikante verbanden met verzuim, indien de andere onderzoeksvariabelen onder kontrole werden gehouden.

\section{Variabele 13: Ontwikkeling personeelsfunktie}

Met deze variabele is door Philipsen getracht op objektieve wijze de mate van ontwikkeling van het personeelsbeleid van een bedrijf vast te leggen. Hij koos voor de volgende globale vierdeling:

1. er is geen aparte personeelschef; het personeelswerk wordt gedaan door de administrateur, de chef loonadministratie, etcetera;

2. er is wel een aparte personeelschef; deze heeft echter in het bedrijf zelf een andere funktie gehad (bijvoorbeeld chef loonadministratie), maar werd personeelschef toen deze funktie gecreëerd werd; hij bezit geen speciale vooropleiding voor de funktie; 
3. er is een personeelschef die als specialist is angetrokken, of na zijn benoeming een speciale opleiding gekregen heeft;

4. het bedrijf heeft een duidelijke aparte afdeling personeelszaken met een academicus an het hoofd.

Philipsen ging ervan uit dat bij een hoge score de kansen op kwaliteit en invloed van de personeelsfunktionaris groter zouden zijn.

Elk bedrijf kreeg een score overeenkomstig de cijfers die vaor de vier alternatieven staan. Hoewel dat niet in de formulering van de antwoordmogelijkheden is terug te vinden, is er bij het 1980/ 81 -onderzoek van uitgegaan dat er bij de alternatieven 2,3 en 4 een personeelsafdeling aanwezig is. Het verschil tussen de scores 2 , 3 en 4 wordt dan uitgedrukt in het verschil in opleiding en achtergrond van de afdelingsleiding. De omvang en kwaliteit van de personeelsafdeling als geheel wordt dus niet direkt door de scores uitgedrukt. Waar de afdeling zich mee bezighoudt komt evenmin in de score tot uitdrukking.

In 1964/65 kwamen alle vier de alternatieven nog voor (de gemiddelde waarde was 2.4 met een standaard-deviatie van 0.9 ). Echter, in 1980/81 kwam het eerste alternatief - geen aparte personeelschef - niet meer voor! Het gemiddelde lag ook veel meer near de rechterkant van de schaal (2.8), terwijl de standaard-deviatie kleiner was (0.6). Om precies te zijn waren er 26 bedrijven met score 2, 53 bedrijuen met score 3 en zes bedrijven met score 4 . Kortom, het is duidelijk dat de operationalisering van deze variabele in de huidige tijd niet goed meer voldoet. Bij latere analyses zal hij ook niet meer gebruikt worden. Variabele 23 (de grootte van de personeelsafdeling in relatie tot het totale personeelsbestand) zal als alternatief gebruikt worden in de vervolganalyse.

\section{Variabele 14: De mate van profesgionele personeelsbegeleiding}

Door middel van faktoranalyse identificeerde Philipsen destijds vier subvariabelen die $h i j$ te zamen als de mate van professionele personeelsbegeleiding in medische en bedrijfspsychologische zin benoemde.

De informatie voor deze variabele is afkomstig van de personeelschef en heeft betrekking op de volgende vier (groepjes) deelvariabelen: 
1. gebrulkt men bij de selektle van werknemers referenties? Voert men bij de selektie gesprekken met gesystematiseerde, op de plaatsing gerichte, vragen? Gebruikt men bij de selektie tests? Bij elk van deze drie vragen waren de antwoordmogelijkheden: nee (score 1), soms (2), altijd (3). De drie antwoorden werden opgeteld, door drie gedeeld en afgerond op hele getallen $(1,2$ of 3$)$;

2. is de selektie van personeel en de beoordeling van het personeel niet atreng (score 1), matig streng (2) of streng (3) te noemen? De antwoorden op beide vragen werden opgeteld, door twee gedeeld en afgerond op hele getallen $(1,2$ of 3 );

3. zijn er niet of wel bedrijfsgeneeskundige voorzieningen voor het personeel? (score 1 of 2);

4. vindt er medische keuring plaats bij personeelsselektie (dus bij de aanstellingsprocedure)? nee (score 1), ja (score 2).

De minimale totaal-score was derhalve 4 en de maximale kon 10 bedragen.

De korrelaties tussen de vier deelvariabelen valgen hieronder:

1. mate van gebruik van referenties, gesprekken en test bij selektie

2. strengheid bij personeelsselektie en -beoordeling

3. bedrijfsgeneeskundige voorzieningen aanwezig

4. medische keuring bij aanstellingen toegepast

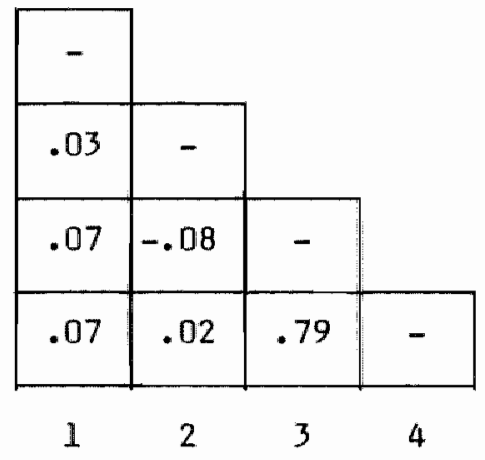

Men ziet dat alleen de derde en vierde deelvariabele sterk met elkaar korreleren, maar dat de rest geen verband met elkaar heeft.

Deze variabele vertoont dus een lage interne konsistentie (Cronbach's Alpha .23). In het onderzoek van Philipsen was deze veel hoger (koëfficiënt van Hoyt .70). De spreiding van de deelvariabelen over de bedrijven was, behalve bij de tweede deelvariabele, onbevredigend (zie Bijlage I): 
deelvariabele 1: gemiddelde 2.1; standaard-deviatie 0.3; deelvariabele 2: geniddelde 2.2; standaard-deviatie 0.6; deelvariabele 3 : gemiddelde 1.9 ; standaard-deviatie 0.2 ; deelvariabele 4: gemiddelde 1.9 ; standaard-deviatie 0.2 .

Men ziet dat de eerste, derde en vierde deelvariabele bijna niet spreiden. Bijna alle bedrijven vertonen op deze variabelen score 2. Alleen de tweede deelvariabele (selektie- en beoordelingsstrengheid) spreidt behoorlijk. Dit betekent derhalve dat de hoofdvariabele voornamelijk selektie- en beoordelingsstrengheid indiceert!

De gebrekkige spreiding van de deelvariabelen en de daardoor ontstane lage interne konsistentie van de hoofdvariabele heeft ertoe geleid dat in latere analyses (hoofdstuk 7) variabele 24 , die de tijdsbesteding van de personeelsafdeling met betrekking tot personeelsbegeleiding en -zorg weergeeft, als vervanger gebruikt zal worden.

\section{Variabele 15: Gunstige uitkeringsvoorwaarden bij ziekte}

Deze variabele heeft, zouls dat ook bij de vorige - ontwikkeling van de personeelsfunktie - het geval was, de 'tand des tijds" niet goed doorstaan. De uitkeringsvoorwaarden bij ziekte zijn namelijk van 1964/65 tot 1980/81 dusdanig verbeterd dat er nog maar heel weinig bedrijven voorkomen war het personeel niet over de meest optimale uitkeringsvoorwaarden bij ziekte beschikt. Daarop wordt verderop teruggekomen.

Eerst valgt hier de operationalisering van de variabele. Deze bestaat uit twee objektieve gegevens, waarvan het eerste de wachtdagenregeling bij ziekte indiceert en het tweede de loonvergoeding bij bezoek aan een huisarts.

Philipsen onderscheidde drie globale wachtdagenregelingen:

- de werknemer ontvangt geen uitkering of loon over - tenminste - de eerste ziektedag; dit bij elk ziektegeval of bij elk ziektegeval dat minder dan 4 weken duurt (score 1). In 1964/65 betrof dit dertien bedrijven; in 1980/81 waren er géén bedrijven met deze regeling;

- de werknemer heeft een onvoorwaardelijk risiko van enkele uren of een voorwardelijk risiko van een halve of hele dag, die hij bij een afwezigheid van bijwoorbeeld 4 dagen of een week toch uitbetaald krijgt (score 2). In 1964/65 betrof dit 34 bedrijuen; in 1980//81 drie; 


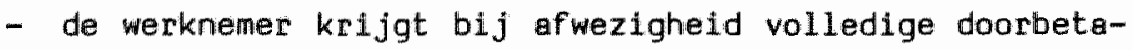
ling van loan, ook voor de eerste dag (score 3). Betrof dit in 1964/65 36 bedrijven, in 1980/81 waren het er 82 . Uit de verdeling van de bedrijven over de drie kategorieën in $1964 / 65$ en in 1980/81 ziet men reeds hoe sterk de situatie veranderd is. De gemiddelde waarde van deze deelvariabele veranderde in de tijd van 2.3 naar 3.0 (zie Bijlage I).

De tweede deelvariabele heeft betrekking op de loonvergoeding aan het personeel bij bezoek van de huiserts. Dok hier werd een driedeling gebruikt:

- geen loonvergoeding bij huisartsbezoek (score 1). Voor hoeveel bedrijuen dit in 1964/65 gold is niet bekend, in $1980 / 81$ gold dit voor twee bedrijven;

- 2 uur loanvergoeding bij huisartsbezoek (score 2). In 1980/81 was dit bij 27 bedrijven het geval;

- gehele loonvergoeding bij huisartsbezoek (score 3). In 1980/81 bestond deze regeling voor 56 bedrijven.

In 1964/65 was de gemiddelde waarde van deze deelvariabele 2.1, terwij1 deze waarde in 1980/81 2.6 bedroeg (zie Bijlage I). Dok hier ziet men dus eenzelfde ontwikkeling in de tijd van minder near meer gunstig.

Opgemerkt kan nog worden dat een aantal bedrijven volgens eigen zeggen met deze regeling de hand lichtten, dat wil zeggen dat in de praktijk de ogen gesloten werden voor eventuele overtredingen van bijvoorbeeld het 2-uur criterium. Zoveel mogelijk is dan ook de praktijksituatie en niet de - onder het personeel soms niet eens bekende - formele regeling gekodeerd.

Tabed 5.6. De verdeling van de bedrijven over de twee subvariabelen wan variabele 15

\begin{tabular}{|l|c|c|c|c|}
\hline \multirow{2}{*}{ wacht dagenregeling } & \multicolumn{3}{|c|}{$\begin{array}{c}\text { loonvergoeding bij } \\
\text { huisartsbezoek }\end{array}$} & \multirow{2}{*}{ totaal } \\
\cline { 2 - 5 } & geen & twee uur & geheell & \\
\hline ongunstige wacht dagenregeling & 0 & 0 & 0 & 0 \\
gemiddelde wachtdagenregeling & 0 & 3 & 0 & 3 \\
gungtige wachtdagenregeling & 2 & 24 & 56 & 82 \\
\hline totaal & 2 & 27 & 56 & 85 \\
\hline
\end{tabular}


Zoals men ziet uit tabel 5.6 is variabele 15 eigenlijk alleen gebaseerd op de verschillen in de mate van loonvergoeding bij bezoek aan de huisarts.

Philipsen vond voor $1964 / 65$ een samenhang tussen beide deelvariabelen van $r=.32$. Deze samenhang bedroeg in $1980 / 81 r=.23$, maar betekent niets, zoals tabel 5.6 laat zien.

De konklusie uit het voorgaande is dat de variabele gunstige uitkeringsvoorwaarden, vanwege de geringe spreiding, wel in de replikatie-analyse, maar niet in de latere analyses opgenomen zal worden.

\section{Variabele 16: Sterke band met het GAK/Bedrijfovereniging}

De Ziektewet in Nederland kent drie verzekeringvormen tegen loonderving wegens zlekte van werknemers. De bedrijuen die één van deze drie verzekeringsvormen hanteren worden respektievelijk omslaglid, afdelingskas en eigenrisikodrager genoemd. Een bedrijf, waarvoor het GAK of de Bedrijfsvereniging de administratie en de ziektekontrole volledig verzorgt, wordt als omslaglid betiteld. Het verzekerings risiko (loonderving door verzuim) wordt dan gedeeld met alle andere bedrijven in dezelfde Bedrijfsvereniging. Afdelingskassen zijn bedrijven warin de werkgever gezamenlijk met de werknemers het risiko van de ziekengeldverzekering draagt. Zo'n bedrijf heeft ook een afdelingskasbestuur met vertegenwoordigers van de werkgever en de werknemers. Een afdelingskas kan zelf kontroleren maar kan dit ook laten doen door het GAK of de Bedrijfswereniging.

Een derde verzekeringsvorm is die van de eigenrisikodracht. In dit geval houdt de werkgever géén ziekengeldpremie in op het loon van de werknemer, en bij ziekte betealt de werkgever het loon van de werknemer door. Hoewel de eigenrisikodrager onder verantwoordelijkheid wan de Bedrijfsvereniging staat, is hij wel het meest autonoom in de uitvoering van de Ziektewet. Ook een eigenrisikodrager kan zelf kontroleren of dit uitbesteden aan het GAK of de Bedrijfsvereniging.

Deze eerste deelvariabele van variabele 16 is mate van onzelfstandigheid in de uitvoering van de Ziektewet of in de Ziektewetverzekering genoemd. Hierin krijgt een omsleglid score 3 , een afdelingskas score 2 en een eigenrisikodrager score 1.

De tweede deelvariabele heet mate van onzelfstandigheid in de 
zlektewetkontrole. Hierbij krijgt een bedrijf warvan de ziekenkontrole geheel door het GAK of de Bedrijfsvereniging geschiedt score 2 (hieronder vallen dus in ieder geval de omslagleden), en de bedrijuen die de kontrole geheel of gedeeltelijk zelf uitvoeren score 1 .

Een hoge score op de totaal-variabele betekent dus een zeer grote mate van onzelfstandigheid van het bedrijf ten aanzien van verzekering en kontrole met betrekking tot de Zliektewet. Dit betekent met andere woorden een sterke band met het GAK of de Bedrijfsvereniging.

Tabal 5.7 De verdeling van de bedrijven over de twee aubvarlabelen war wariabele 16

\begin{tabular}{|c|c|c|c|}
\hline \multirow{2}{*}{$\begin{array}{l}\text { mate wan onzelf stendigheid in de } \\
\text { Ziektewet-verzekering }\end{array}$} & \multicolumn{2}{|c|}{$\begin{array}{l}\text { mate van onzelfstandigheid in de } \\
Z \text { fiektewet-kontrole }\end{array}$} & \multirow{2}{*}{ tot eal } \\
\hline & $\begin{array}{l}\text { kontrole } \\
\text { gelluel/gedee - } \\
\text { tel } 1 \text { jk zelf }\end{array}$ & $\begin{array}{c}\text { kontrole } \\
\text { geheel dom } \\
\text { GAK/Bedr * ver * }\end{array}$ & \\
\hline \multirow{3}{*}{$\begin{array}{l}\text { eigenrisikodrager } \\
\text { af del ingskas } \\
\text { ans laglid }\end{array}$} & 14 & Q & 22 \\
\hline & 13 & 8 & 21 \\
\hline & $0(n+v+t)$ & 42 & 42 \\
\hline - & 五 & $----m$ & \\
\hline totaral & 27 & 58 & 85 \\
\hline
\end{tabular}

Bij tabel 5.7 kan vermeld worden dat de korrelatie tussen beide deelvariabelen $r=.59$ bedraagt. Bij Philipsen was deze relatie ven gelijke sterkte $(r=.55)$.

Tenslatte zij nog opgemerkt dat in dit onderzoek het aantal omslagleden ondervertegenwoordigd en het aantal afdelingskassen en eigenrisikodragers oververtegenwoordigd is in vergelijking tot de werkelijke situatie in Nederland. In 1978 bijvoorbeeld waren er in Nederland in totaal 892 afdelingskassen en eigenrisikadragers, ofwel nog niet én procent van alle Nederlandse bedrijven. Deze 'AKERs' hadden echter wel ruim 23 procent van alle Nederlandse werknemers in dienst. AKERs zijn dus in de regel relatief grote bedrijuen en een niet te verwaarlozen faktor in de Nederlandse sociale verzekeringen (zie Draaisma, 1983, voor meer details over deze problematiek).

De ondervertegenwoordiging van de omslagleden en de oververtegen- 
woordiging van de AKERs is in dit onderzoek bewust nagestreefd om de variatie tussen de drie kategorieën zo groot mogelijk te maken. In het onderzoek van Philipsen was dat trouwens ook het geval.

\section{Variabele 17: Cemiddelde leeftijd van het produktiepersoneel}

De personeelsafdelingen van de onderzochte bedrijven hebben voor het onderzaek opgegeven hoe de mannelijke produktiewerknemers op 1 januari 1981 over vijf leeftijdskategorieën verdeeld waren. Voor alle 85 bedrijven zagen deze gegevens er, omgerekend in procenten, als volgt uit:

$$
\begin{aligned}
& 15-24 \text { jaar : } \quad 14.9 \text { procent } \\
& 25-34 \text { jaar : } \\
& 35-44 \text { jaar : } \\
& 26.7 \text { procent } \\
& 45-54 \text { jaar : } \\
& 55-64 \text { jaar : } 12.0 \text { procent } \\
& \\
& \text { totaal }
\end{aligned}
$$

Door per bedrijf deze vijf percentages met respektievelijk 20, $30,40,50$ en 60 jaar te vermenigvuldigen, de som daarvan door 100 te delen en af te ronden op hele getallen is per bedrijf een gemiddelde leeftijd vastgesteld. Voor alle 85 bedrijven te zamen bedroeg deze 39,3 jaar, zoals tabel 5.9 in de volgende paragraaf (p. 104-105) laat zien.

\section{Variabele 18: Percentage produktiewerknemers korter dan 1 jaar in dienst}

Op gelijksoortige manier als bij de vorige variabele hebben debedrijuen opgegeven hoe de mannelijke produktiewerknemers op 1 januari 1981 verdeeld waren over drie diensttijdkategorieën. Voor alle 85 bedrijven te zamen zagen deze gegevens er in procenten als volgt uit:
0 - 1 jaar in dienst :
11.5 procent
1 - 10 jaar in dienst :
43.5 procent
langer dan 10 jaar in dienst :
45.0 procent
totaal
100.0 procent

In navolging van Philipsen is voor deze variabele niet de gemiddelde diensttijd, maar het eerste van de drie percentages gebruikt. 
Philipsen vond dat de beperking tot de korte diensttijden twee voordelen had: (a) de sterke relatie tussen leeftijd en diensttijd in het algemeen zou erdoor beperkt blijuen; (b) het sterke verband tussen diensttijd en lengte van het bestaan van het bedrijf (recent gevestigde bedrijven kunnen geen gemiddeld lange diensttijden hebbenl) zou hierdoor niet meer gekorrigeerd behoeven te worden. Met andere woorden: bij gebruik van de variabele gemiddelde diensttijd zou men in principe wel voor de ouderdom van het bedrijf dienen te korrigeren, terwijl dat bij het thans gebruikte percentage niet meer nodig is.

\section{Variabele 19: Stedelijkheidagraad van het gewest waarin het be- drijf ligt}

Het uitgangspunt bij deze variabele was de gedachte dat de stedelijkheidsgraad van de woonplaats van het personeel of van het gewest warin het bedrijf ligt een indikatie is van de waardenorientatie van het personeel. Een zogenaamde 'stedelijke' waardenoriëntatie wordt geacht verzuim-verhogend te werken.

De operationalisering van deze variabele voor het 1980/81-onderzoek wijkt af van die van Philipsen. Hij vroeg namelijk aan alle bedrijven om de gemeente van inwoning van alle produktiewerknemers op te geven. Van alle opgegeven gemeenten werd vervolgens de urbanisatiegraad (platteland - grote stad) volgens het CBS opgezocht en de 'linksheidsscore" berekend uit het percentage stemmers op linkse partijen. Uitgangspunt hierbij was dat het eerste gegeven het strukturele aspekt (de beroepsbevolking) en het tweede gegeven het kulturele aspekt (de 'mentaliteit') van de verstedelijking zou weergeven.

Tenslotte berekende hij vila weging (het aantal werknemers per gemeente) een bedrijfsscore voor zowel de strukturele als de kulturele verstedelijking. Deze twee waarden werden uiteindelijk opgeteld tot één bedrijfsscore. Philipsen mat dus eigenlijk de stedelijkheidsgraad van de woonplaats van de werknemers.

Deze arbeidsintensieve procedure was in dit onderzoek niet mogelijk. Om de aanpak van Philipsen zo dicht mogelijk te benaderen is de volgende methode gevalgd. In een studie van het Centraal Bureau voor de Statistiek (Van Engelsdorp Gastelaars et al., 1980) wordt Nederland - onder meer op basis van intensief intergemeentelijk woon/werkverkeer - ingedeeld in 34 zogenaamde nodale gewesten (die niet per se provincie-gebonden zijn). Deze geweste- 
lijke indeling is goed bruikbaer voor dit onderzoek, omdat bedrijven in $20^{\prime \prime} n$ gewest warschijnlijk het grootste deel van hun personeel binnen dat gewest rekruteren. Het toekennen aan de bedrijven van gemeentekenmerken in plasts van gewestkenmerken zou namelijk het nadeel hebben dat een bedrijf dat veel van zijn personeel van buiten de vestigingsplaats rekruteert, door de betreffende gemeentekenmerken weinig betrouwbaar beschreven wordt. Een gewestkenmerk in plaats van een gemeentekenmerk voldoet dan beter aan het doel dat - zoals vermeld - een poging is tot beschrijving van de waardenoriëntatie van het personeel van het betreffende bedrijf.

Met behulp van gegevens van de volkstelling van 1971 werd door het CBS aan elk gewest een aantal kenmerken toegekend. Twee van deze kenmerken werden voor dit onderzoek gebruikt. Het gaat ten eerste om de agglomeratiegraad op basis van het inwonertal. Vier waarden worden in dit kenmerk onderscheiden (score 1, 2, 3 en 4). Het tweede kenmerk betreft een index voor de sociaal-ekonomische deprivatie. Dit kenmerk is gekozen uit het CBS-onderzoek, omdat gewesten die hier hoog op scoren (de gewesten Amsterdam, Rotterdam, Dost-Groningen, Zuidoost-Drenthe, West-Noord-Brabant en Zuid-Limburg) een relatief groot aantal inwoners hadden die stemmen op linkse partijen (met name de CPN). De CBS-studie hanteert drie warden met betrekking tot dit kenmerk (scores 1,2 en 3 ). Het eerste gewestkenmerk (agglomeratiegraad) komt avereen met Philipsen's eerste deelvariabele; het tweede kennerk (sociarlekonomische deprivatie) heeft veel weg van Philipsen's tweede deelvariabele (de zagenaamde linksheidsscore).

Elk van de 85 onderzoeksbedrijven zijn de twee kenmerken toegekend van het gewest warin het ligt. Door optelling van beide kenmerken kan een bedrijf een ininimale score van 2 hebben (het bedrijf ligt dan in een gewest met een plattelandskarakter en een relatief gering aantal linkse stemmers) en een maximale score van 7 (het bedrijf ligt dan in een sterk verstedelijkt gewest met een groot aantal linkse stemmers).

De verdeling van de 85 bedrijven over beide kenmerken wordt in tabel 5.8 (p. 102) weergegeven.

De relatie tussen beide stedelijkheidskenmerken is $\mathrm{r}=.49$. Naarmate de wardenoriëntatie van het personeel meer stedelijk (meer 'cosmopolitan' in termen van Turner en Lawrence, 1965) of meer markt-gericht is, verwachtte Philipsen dat de verzuimfrekwentie hoger zou zijn. 
Tabel 5.8 De verdeling van de bedrifwen over de twee subwariabelen van varlabele 19

\begin{tabular}{|c|c|c|c|c|}
\hline \multirow{2}{*}{ agglomerat i egrabd gramst. } & \multicolumn{3}{|c|}{$\begin{array}{c}\text { Baciaal-ekonomische diep i vat ie } \\
\text { wan het gewest }\end{array}$} & \multirow{2}{*}{ total } \\
\hline & bijna geen ? & enilge & sterke & \\
\hline zwak geagglomemeerd & 3 & 4 & 1 & 8 \\
\hline vil zwak geagglonereerd & 26 & 3 & 0 & 29 \\
\hline vrij sterk geagglomereerd & 23 & 3 & 3 & 29 \\
\hline sterk gealgg lonereerd & 3 & 0 & 16 & 19 \\
\hline 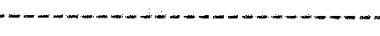 & & & & \\
\hline totaal & 55 & 10 & 20 & 85 \\
\hline
\end{tabular}

5.3 Vergelijking van beide onderzoeken op de methodische aspekten: het replikatiekarakter

Van de negentien replikatievariabelen is nu beschreven hoe ze samengesteld en gemeten zijjn.

Met het oog op het replikatiekarakter van het onderzoek is het daarom nu mogelijk systematisch in te gaan op de verschillen in de methodische aspekten van de onderzoeken uit respektievelijk $1964 / 65$ en $1980 / 81$.

Volgens Galtung (1967, p. 437-450) is het doel van replikatie-onderzoek, naast kennisvermeerdering en de generalisatie van resultaten, na te gaan of eerdere resultaten artefakten (kunstmatige produkten) zijn van de methodische aspekten van het onderzoek. Tot deze aspekten behoren de analyse-eenheden, de wijze van materiaalverzamelen, de inhoud van de variabelen en de waarden van de variabelen, zoals gemiddelden en spreiding.

Beide onderzoeken zullen nu op deze vier punten vergeleken worden, warbij de vraag is op welke ze overeenkomen en verschillen.

\section{De enalyse-eenheden}

In 1964/65 waren dat $B 3$ produktiebedrijven met merendeels mannelijk produktiepersoneel uit zeven bedrijfstakken, regionaal verdeeld over geheel Nederland. Deze bedrijuen hadden minimaal 120 en maximael 960 werknemers in dienst.

De bedrijven uit $1980 / 81$ werden door middel van eenzelfde steekproefprocedure uit een universum met ongeveer gelijke kenmerken als in 1964/65 getrokken (men denke aan de kenmerken produktie- 
proces/bedrijfstak, produktie- en totale personeelsomvang, regio, deelname aan de NIPG-verzuinstatistiek). Dit is van belang in verband met de replikatie-opzet van de analyse.

In concreto was in $1980 / 81$ het antal onderzoekseenheden 85 produktiebedrijven met eveneens merendeels mannelijk produktiepersoneel uit zo goed als dezelfde bedrijfstakken en dezelfde regio"s. Ze waren gemiddeld lets groter in personeelsomvang dan in 1964/ 65. Voor details zie men de tabellen 3.4 en 3.5 ( $p$. 51) en tabel 5.9 (p. 104).

Wel is het zo, dat - ondanks dezelfde universa en steekproefprocedures - in de uiteindelijke resultaten steekproefvariaties een rol zullen spelen. Geheel identieke resultaten mogen daarom niet verwacht worden.

\section{De methode van materiaalverzamelen}

Het tweede methodische aspekt dat volgens Galtung (1967) bekeken dient te worden is de methode van materiaalverzamelen.

In grote mate was de wijze van materiaalverzamelen in 1980/81 dezelfde als in 1964/65. Evenals in het oorspronkelijke onderzoek zijn de meeste variabelen gebaseerd op dokumentatiegegevens, meestal afkomstig van de afdeling Personeelszaken. Varlabelen met een meer subjektieve inhoud, zoals de fysieke werkomstandigheden en delegatie van bevoegdheden, zijn in beide onderzoeken gemeten door vragenlijsten voor te leggen aan twee sleutelinformanten, de bedrijfsleider en de personeelschef (zie Bijlage II).

Konkluderend: de methode van materiaalverzamelen van beide onderzoeken geeft weinig aanleiding te denken dat eventuele verschillen in resultaten daaraan geweten zullen mogen worden.

\section{De inhoud van de variabelen}

De negentien variabelen die in 1964/65 werden gebruikt, werden dit ook in 1980/81. Eén duidelijke afwijking valt te vermelden. Dit betreft de operationalisering van variabele 19 (stedelijkheidsgraad). In $1964 / 65$ ging het om de stedelijkheidsgraad van de woonplaats van het personeel van het bedrijf in kwestie, terwijl in 1980/81 de stedelijkheidsgraad van het gewest waarin het bedrijf gevestigd is, als basis genomen werd. Verder werd bij variabele 13 (ontwikkeling personeelsfunktie) de vraag in 1980/81 meer toegespitst op de personeelsafdeling; in 1964/65 refereerde de vraag meer aan de personeelschef. Dus allean bij de variabelen 
Tabel 5.9 Cemlddelde en aprelding van de negentlen werklarende wariabelen In respekt levelijk $1964 / 65$ en $1980 / 91$

\begin{tabular}{|c|c|c|c|c|c|}
\hline \multirow{2}{*}{\multicolumn{2}{|c|}{ varLabelen }} & \multicolumn{4}{|c|}{$1964 / 65(n=83)$} \\
\hline & & $\begin{array}{l}\text { theoret imelne } \\
\text { varlat le- } \\
\text { breedte }\end{array}$ & $\begin{array}{l}\text { empliflache } \\
\text { varietle- } \\
\text { breedte }\end{array}$ & $\begin{array}{l}\text { gemidi- } \\
\text { delde }\end{array}$ & $\begin{array}{l}\text { stendaerd- } \\
\text { devilat le }\end{array}$ \\
\hline & $\begin{array}{l}\text { technologlach gebonden } \\
\text { produkt } 1 \text { eproces (rout }- \\
\text { nisering) }\end{array}$ & $2-8$ & $2-8$ & 5.10 & 1.8 \\
\hline 2 & $\begin{array}{l}\text { arbeidsuteneltelt van } \\
\text { de orgenlsatle (percen- } \\
\text { tege arbeldskosten) }\end{array}$ & $0-100 x$ & $3-60 \%$ & $25.4 \%$ & $12.9 \times$ \\
\hline & $\begin{array}{l}\text { onrust in het produlkt ie- } \\
\text { proces }\end{array}$ & $0-6$ & $0-6$ & 3.0 & 1.5 \\
\hline 4 & $\begin{array}{l}\text { percentrge produktie- } \\
\text { werknemers in ploegen- } \\
\text { diengt }\end{array}$ & $0-1,00 \%$ & $0-99 \%$ & $31.4 \%$ & $30.7 \%$ \\
\hline 5 & $\begin{array}{l}\text { hinder } 1 \text { jlke fysieke } \\
\text { werkonst anidgheden }\end{array}$ & $16-80$ & $25-71$ & 40.4 & 9.1 \\
\hline & $\begin{array}{l}\text { scholingagraad produk- } \\
\text { tlewerk }\end{array}$ & $1.0-3.0$ & $1.2-2.8$ & $2+1$ & 0.3 \\
\hline 7 & $\begin{array}{l}\text { delegatie aan niet-lei- } \\
\text { dinggevenden }\end{array}$ & $1-13$ & $1-11$ & 5.1 & 2.8 \\
\hline & $\begin{array}{l}\text { autonomile } 1 \text { in de be- } \\
\text { drijfgivering }\end{array}$ & $3-9$ & $3-9$ & 5.8 & 2.1 \\
\hline 9 & $\begin{array}{l}\text { niet-uitgewerkte orge- } \\
\text { nisatiestruktuur } \\
\text { (plathel dsgraad) }\end{array}$ & $1-?$ & $3-32$ & 14.2 & 4.9 \\
\hline 10 & bedillfsgrootte & $100-999$ & $120-960$ & 387 & 200 \\
\hline & $\begin{array}{l}\text { bedrilff autoritair ge- } \\
\text { leid }\end{array}$ & $1-5$ & $1-5$ & 3.4 & 1.0 \\
\hline 12 & $\begin{array}{l}\text { slechte 'noam' van het } \\
\text { bedrijf (arbeldismarkt- } \\
\text { positie) }\end{array}$ & $4-14$ & $4-14$ & 7.7 & 2.4 \\
\hline 13 & $\begin{array}{l}\text { ontwlkkeling personeels- } \\
\text { funktie }\end{array}$ & $1-4$ & $1-4$ & 2.4 & 0.9 \\
\hline 14 & $\begin{array}{l}\text { praf egalonele prersio- } \\
\text { neelsbegelel ding }\end{array}$ & $4-10$ & $4-10$ & 6.6 & 1.8 \\
\hline 15 & $\begin{array}{l}\text { gunst lge uitkerings- } \\
\text { voorwareden blj zitekte }\end{array}$ & $2-6$ & $2-6$ & 4.4 & 1.1 \\
\hline & $\begin{array}{l}\text { aterke band mat GAK/ } \\
\text { Bedrljfovereniging }\end{array}$ & $2-5$ & $2-5$ & 3.7 & 1.1 \\
\hline 17 & $\begin{array}{l}\text { gemi ddelde leeft ijd } \\
\text { produkt lepersoneel }\end{array}$ & $20-60$ & $20-51$ & 38.7 & 4.0 \\
\hline 18 & $\begin{array}{l}\text { peroentage produkt le- } \\
\text { werknemers korter dan } \\
\text { l jaar in duenst. }\end{array}$ & $0-100 \%$ & $0-49 x$ & $16.1 \%$ & 8. 94 \\
\hline & $\begin{array}{l}\text { atedel } 1 \text { jkheldegraad } \\
\text { woonplats personeel }\end{array}$ & $0-17$ & $2-14$ & 8.3 & 3.5 \\
\hline
\end{tabular}

* Bror: Philipsen (1969, p. 148) 


\begin{tabular}{|c|c|c|c|c|c|}
\hline \multirow{2}{*}{\multicolumn{2}{|c|}{ variabelien }} & \multicolumn{4}{|c|}{$1980 / 81(n=85)^{* *}$} \\
\hline & & $\begin{array}{l}\text { theoretische } \\
\text { variatie- } \\
\text { breedte }\end{array}$ & $\begin{array}{l}\text { empirische } \\
\text { variatie- } \\
\text { breedte }\end{array}$ & $\begin{array}{l}\text { gemid- } \\
\text { delde }\end{array}$ & $\begin{array}{l}\text { standarard- } \\
\text { deviatie }\end{array}$ \\
\hline & $\begin{array}{l}\text { technologisch gebonden } \\
\text { produktieproces (rout1- } \\
\text { nisering) }\end{array}$ & $2-8$ & $2-8$ & 5.4 & 1.5 \\
\hline 2 & $\begin{array}{l}\text { arbeidsintensiteit van } \\
\text { de organisatie (percen- } \\
\text { toge arbeldskosten) }\end{array}$ & $0-100 \%$ & $4-77 \%$ & $36.4 \%$ & $17.7 \%$ \\
\hline & $\begin{array}{l}\text { anrust in het produktie- } \\
\text { proces }\end{array}$ & $0-6$ & $1-6$ & 3.9 & 1.2 \\
\hline $4 \mathrm{~F}$ & $\begin{array}{l}\text { percentige produkt ie- } \\
\text { werknemers in ploegen- } \\
\text { dienst }\end{array}$ & $0-100 \%$ & $0-100 \%$ & $43.5 \%$ & $37.4 \%$ \\
\hline & $\begin{array}{l}\text { hinderlijke fysieke } \\
\text { werkomstanidgheden }\end{array}$ & $16-80$ & $20-51$ & 34.1 & 6.5 \\
\hline & $\begin{array}{l}\text { schal ingsgraad produk- } \\
\text { tiewerk }\end{array}$ & $1.0-3.0$ & $1.2-3.0$ & 2.2 & 0.4 \\
\hline & $\begin{array}{l}\text { delegat le вan niet-lei- } \\
\text { dinggevenden }\end{array}$ & $2-8$ & $2-7$ & 3.9 & 1.2 \\
\hline & $\begin{array}{l}\text { autonomie in de be- } \\
\text { drijfsvoering }\end{array}$ & $3-9$ & $3-9$ & 6.0 & 1.2 \\
\hline & $\begin{array}{l}\text { nlet-uitgewerkte orga- } \\
\text { nilsatieatruktuur } \\
\text { (platheidsgraad) }\end{array}$ & $1-?$ & $5-36$ & 12.8 & 5.4 \\
\hline 10 & bedrijfsgroot te & $100-1200$ & $166-1571$ & 484 & 281 \\
\hline & $\begin{array}{l}\text { bedrijf autoritair ge- } \\
\text { leid }\end{array}$ & $1-5$ & $1-5$ & 2.8 & 0.9 \\
\hline 12 & $\begin{array}{l}\text { slechte "noam" van het } \\
\text { bedrijf (arbeidamarkt- } \\
\text { positie) }\end{array}$ & $2-7$ & $2-7$ & 3.8 & 1.3 \\
\hline & $\begin{array}{l}\text { ontwikkeling personeels- } \\
\text { funktie }\end{array}$ & $1-4$ & $2-4$ & 2.8 & 0.6 \\
\hline & $\begin{array}{l}\text { professionele perso- } \\
\text { neelsbegeleiding }\end{array}$ & $4-10$ & $6-110$ & 8.2 & 0.8 \\
\hline & $\begin{array}{l}\text { gunstige uitkeringe- } \\
\text { voorwarden bij ziekte }\end{array}$ & $2-6$ & $4-6$ & 5.6 & 0.6 \\
\hline 16 & $\begin{array}{l}\text { sterke band met GAK/ } \\
\text { Bedrijfswereniging }\end{array}$ & $2-5$ & $2-5$ & 3.9 & 1.2 \\
\hline 17 & $\begin{array}{l}\text { gemiddel de leeft } 1 \text { jd } \\
\text { produkt lepersoneel }\end{array}$ & $20-60$ & $31-47$ & 39.3 & 3.4 \\
\hline 18 & $\begin{array}{l}\text { percentage produktie- } \\
\text { werknemers korter dan } \\
1 \text { jaor in dienst }\end{array}$ & $0-100$ & $0-32 \%$ & 11.48 & $6.6 \%$ \\
\hline 19 & $\begin{array}{l}\text { stedelijkheidsgraad } \\
\text { gewest bedrijf }\end{array}$ & $2-7$ & $2-7$ & 4.3 & 1.5 \\
\hline
\end{tabular}

* Bijlage I geeft het gemiddelde en de spreiding van de subveriabelen wan de hier vermelde negentien variabelen 
13 en 19 wijkt de inhoud van het latere onderzoek enigozins af van het oorspronkelijke.

\section{De theoretiache en empiriache waarden van de variabelen}

De schalindelingen van de variabelen waren in 1980/81 in grote lijnen dezelfde als in 1964/65. De volgende vier uitzonderingen kunnen vermeld worden (zie tabel 5.9, p. 104-105). Ten eerste was de maximale waarde van de bedrijfsgrootte in $1980 / 81$ afwijkend van die uit 1964/65; ten tweede was de theoretische variatiebreedte van de variabele delegatie in $1964 / 651-13$ en in $1980 / 81$ 2-8. Bij de stedelijkheidsgraad waren deze cijfers in 1964/65 017 en in 1980/81 2-7. Tenslatte zijn de twee vragen betreffende de 'naam' van het bedrijf in 1980/81 niet aan beide sleutelinformanten voorgelegd zoals in 1964/65, maar alleen aan de bedrijfsleider, waardoor de theoretische variatiebreedte niet 4-14 bedraegt, maer 2-7.

op deze vier variabelen kunnen dus afwijkingen tussen beide onderzoekingen ontstaan.

Tabel 5.9 vermeldt niet alleen de theoretische, maar ook de empirische variatiebreedten, de gemiddelden en de standaard-deviaties van de variabelen uit $1964 / 65$ en $1980 / 81$. Voor de vergelijking van beide onderzoekingen zijn echter de empirische variatiebreedten en de standaard-deviaties belangrijker dan de theoretische variatiebreedten.

De spreiding van de variabelen arbeidsintensiteit (2), ploegendienst (4), bedrijfsgrootte (10), en in mindere mate band met het GAK of de Bedrijfsvereniging (16) is duidelijk vergroot ten opzichte van het oorspronkelijke onderzoek.

Anderzijds zijn vijf variabelen zo sterk in spreiding verminderd dat ze minder bruikbar lijken geworden. Dit zijn (zie tabel 5.9 en Bijlege I):

3. onrust in het produktieproces;

8. autonomie in de bedrijfsvoering;

13. ontwikkeling personeelsfunktie;

14. professionele personeelsbegeleiding;

15. gunstige uitkeringsvoorwarden.

De volgende redenen $z i j n$ hilervoor te noemen. Bij onrust

spreidt de belangrijke subvariabele konkurrentie weinig (zie Bijlage $I$ ). Bij autonomie (8) spreidt de subvariabele familiebedrijf 
matig, maar gezien het feit dat de twee andere - waronder de belangrijkste: zelfstandigheid - wel goed spreiden, is deze variabele wel te handhaven voor de vervolganalyse. De interne konsistentie is ook hoger. (Alphe is 0.44 ). Door de verouderde operationalisering van de één-item variabele ontwikkeling personeelsfunktie (13) spreiden de scores hierop slecht. Verder kunnen de toets der kritiek moeilijk doorstaen: professionele personeelsbegeleiding (14), waarbij drie van de vier subvariabelen gering spreiden, en gunstige uitkeringsvoorwaerden (15), warbij de belangrijkste subvariabele: wachtdagenregeling, zo goed als niet spreidt.

Door hun geringe spreiding moeten vier ven de vijf hierboven genoemde variabelen als minder bruikbaar gekarakteriseerd worden. Zij zullen alleen in de replikatie-analyse opgenomen worden en niet in de vervolganalyse in hoofdstuk 7 .

Over de resterende variabelen kan opgemerkt worden dat veruit het merendeel van de gebruikte mér-item variabelen een goede bruikbaarheid vertoont. Indikaties hiervoor zijn te vinden in een goede spreiding van de betreffende variabelen en een voldoende interne konsistentie (Cronbach's Alpha's). Bovendien was positief, dat door middel van tweevoudige variantie-analyses bïj de variabelen 1, 5 en 7 aangetoond kon worden dat de scores hierop niet te wijten waren aan inkonsistente verschillen in opinie tussen de twee respondenten (bedrijfsleider en personeelschef) maar aan "echte" verschillen tussen de 85 bedrijven.

Bij de resterende één-item variabelen zijn uitspraken over bruikbaarheid niet te baseren op hun interne konsistentie, maar wel op indrukken en observaties tijdens de intervilews, op de non-respons en op de degelijkheid van de personeelsadministratie.

Het blijkt dan dat het slechts bij twee variabelen, namelijk bij het arbeidskostenpercentage (2) en de vraag of het bedrijf demokratisch of autoritair geleid wordt (11), voorgekomen is dat de gegevens van een paar bedrijven ontbraken. Zoals vermeld, zijn bij die par bedrijven voor deze variabelen bedrijfatak-scores respektievelijk gemiddelde scores ingevuld. Deze geringe zwakheden staan de betrouwbarheid van deze variabelen niet in de weg. Bij variabele 2 waren er echter wel interpretatieproblemen die de betrouwbarheid verzwakken. Daarom zal deze variabele niet in de vervolganalyse terugkomen.

Konkluderend valt dus op te merken dat de 85 bedrijuen in het 
huidige onderzoek homogener van opbouw waren dan de 83 bedrijven van Philipsen. Met andere woorden: op de betreffende negentien punten Iijken de huidige bedrijven lets meer op elkaar. Hierop wordt in het volgende hoofdstuk nog teruggekomen.

Het laatste te behandelen aspekt in het kader van de bespreking van de theoretische en empirische warden van de variabelen in $1964 / 65$ en in 1980/81 betreft de verandering in de gemiddelden van de negentien verklarende variabelen. Bij de vergelijking van de gemiddelden, rekeninghoudend met de steekproefgrootten en de standaerd-deviaties van de gemiddelden, blijkt dat de bedrijuen in $1980 / 81$ op de volgende twalf punten signifikant verschillen van de bedrijuen uit 1964/65:

- grotere arbeidsintensiteit;

- meer onrust in het produktieproces;

- groter percentage ploegendienstwerknemers;

- minder hinderlijke werkomstandigheden;

- meer delegatie van verantwoordelijkheid;

- minder platte organisatievorm;

- grotere bedrijfsgrootte;

- minder autoritaire leiding van de bedrijuen;

- meer ontwikkelde personeelsfunktie;

- meer professionele personeelsbegeleiding;

- gunstiger uitkeringsvoorwarden bij ziekte;

- minder personeel met korte diensttijden.

Het gaat hier te ver om deze veranderingen te bespreken. Dit zal meer in detail geschieden in de slotbeschouwing (hoofdstuk 8).

Samengevat kan men konkluderen dat, afgezien van detailpunten, het replikatie-onderzoek uit $1980 / 81$ wat betreft de inhoud van de variabelen, de theoretische warden van de variabelen en de methode van materiaalverzamelen weinig afwijkt van dat uit 1964/65. Hoewel de latere onderzoekseenheden niet dezelfde zijn als de oorspronkelijke, zijn er duidelijke overeenkomsten wat betreft bedrijfstak, produktieproces en regio. Verschillen in onderzoeksresultaten zullen daarom waarschijnlijk ook niet toegeschreven kunnen worden aan het feit dat een steekproef van bedrijuen uit een geheel andere populatie van bedrijven is getrokken. Wel vindt men in de resultaten uiteraard steekproefvariaties terug. 
Indien het onderzoek uit $1980 / 81$ andere resultaten oplevert dan het onderzoek uit $1964 / 65$, kunnen de verschillen waarschijnlijk voornamelijk toegeschreven worden aan:

- het feit dat de empirische waarden (gemiddelden en standaard-deviaties) bij een ruim aantal variabelen in beide perioden signifikant van elkaar verschillen;

- de mogelijkheid dat er nog ongemeten variabelen kunnen zijn die in beide perioden sterk van elkear verschillen en die in de eerdere periode een endere doorkruisende invloed op de relaties uitoefenen dan in de latere periode; men kan hierbij denken an de financieel-ekonomische positie van de bedrijven en het percentage buitenlandse werknemers, die beide ontbreken in de replikatieanalyse.

\subsection{Beschrijving van de dertien toegevoegde verkla- rende variabelen voor de vervolganalyse}

In paragraaf 5.1 is reeds beargumenteerd warrom de variabelen 20 tot en met 32 in het onderzoek zijn opgenomen. In het kort komt het erop neer dat de nummers 20 tot en met 24 de oorspronkelijke variabelen $1,3,9,13$ en 14 vervangen, en de nummers 25 tot en met 32 toegevoegd zijn om de theoretische begrippen verzuingelegenheid, verzuimnoodzaak, verzuimbehoefte (binding) en aandacht voor het individuele ziektegeval meer 'body' te geven.

$B i j$ elk van de volgende variabelen zal het verondersteld verband met de verzuimmaten beargumenteerd worden. Deze verbanden werden reeds in het hypothetisch schema (tabel 5.1) opgenomen. De gemiddelden en standara-deviaties van de variabelen en subvariabelen worden weergegeven in tabel 5.17 en Bijlage I.

\section{Variabele 20: Onrust in het produktieproces (nieuwe versie)}

De door Philipsen vervaardigde variabele onrust (3) bestond uit de som van drie deelvariabelen: de mate van storingen in het produktieproces, de mate warin op voorraad of bestelling geleverd werd en de mate van konkurrentie. Uit de in dit onderzoek verzamelde gegevens bleek echter dat deze drie onderdelen zeer laag interkorreleerden en dat de deelvariabele konkurrentie niet goed bruikbaar was door een geringe spreiding over de bedrijven. 
Deze felten waren een reden on te zoeken nas een betere operationalisering van het begrip onrust. Daartoe werd de deelvariabele storingen uit variabele 3 (onrust) te zamen met beide deelvariabelen van nummer 1 (produktieprocestype en vrijheid in werktempo en werkonderbrekingen) en een aantal niet door Philipsen gebruikte variabelen om aspekten van het produktieproces te beschrijven, gefaktoranalyseerd. De deelvariabele produktieprocestype werd voor dit doel niet op de Philipsen-wijze maar op de Woodward-wijze geoperationaliseerd (Woodward, 1965), dus: 1 = enkelstuks-, 2 = serie-, 3 = massa- en 4 = procesproduktie. Dit werd gedaan om aansluiting te behouden bij het vele Angelsaksische onderzoek dat uitgevoerd werd met de Woodward-schaal.

Uit de faktoranalyse kwamen twee faktoren naar voren: de eerste kon onrust genoend worden en geïndiceerd worden door produktieprocestype te zamen met storingen en de tweede faktor kon vrijheid genoemd worden en geindiceerd worden door vrijheid in werktempo/-onderbrekingen te zamen met de nieuw-ingevoerde vierpuntsschaal duur van de arbeidscyclus.

De eerste faktor zal als variabele 20 en de tweede als variabele 21 fungeren. De interkorrelaties tussen de vier deelvariabelen uit de variabelen 20 en 21 zijn als volgt:

20-1 produktieprocestype (enkelstuksproces; BL)

20-2 mate van storingen door toeleveringsproblemen of door onvoldoende kwaliteit grondstoffen (BL)

21-1 mate van vrijheid in werktempo en -onderbrekingen (som BL en $\mathrm{PZ}$ )

21-2 duur van de arbeidscyclus (BL)

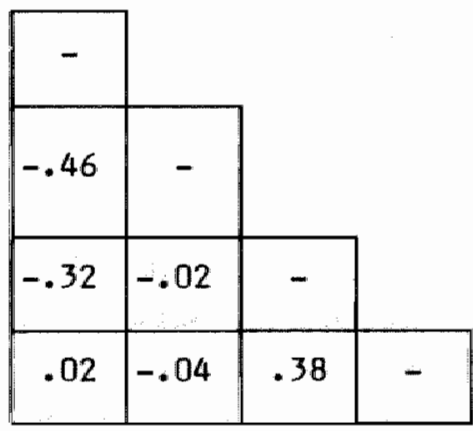

$20-1 \quad 20-2 \quad 21-1 \quad 21-2$

$B L=$ volgens bedrijfsleider; $P Z=$ volgens personeelschef.

Vastgesteld kan nu worden dat het produktieprocestype in de Woodward-volgorde minder sterk korreleert met de andere deelvariabele (vrijheid) dan de operationalisering van het produktieprocestype van Philipsen (namelijk .32 tegen .57). Blijkbaar heeft de Woodward-volgorde minder met vrijheid te maken dan de Philipsen-volgorde. Bovendien blijkt nu dat het produktieproces in de Woodward- 
volgorde op één faktor laadt samen met mate van storingen ( $\mathbf{r}=$ .46), en dat vrijheid in werktempo, etcetera op een andere faktor laadde samen met duur van de arbeidscyclus $(r=.38)$. Het praduktieproces in de Woodward-volgorde lijkt derhalve meer een automatiseringsvolgorde, terwijl het produktieproces in de Philipsenvolgorde meer een routiniseringsvolgorde lijkt.

Tabe1 5.10 De werdeling van de bedrijven aver de twee subvariabelen van varlabele 20

\begin{tabular}{|l|c|c|c|c|}
\hline \multirow{2}{*}{ produkt leprocestype } & \multicolumn{3}{|c|}{ matie van storingen } \\
\cline { 2 - 5 } & in sterke mete & enigermate & nooit \\
\hline enkelstuk & 5 & 3 & 1 & 9 \\
serie & 16 & 18 & 2 & 36 \\
massa & 2 & 15 & 9 & 22 \\
proces & 2 & 7 & 18 \\
\hline totagl & 25 & 43 & 17 & 95 \\
\hline
\end{tabular}

Uit tabel 5.10 valt te konkluderen dat het verband tussen beide deelvariabelen van variabele 20 tamelijk rechtlijnig is; van enkelstuksproduktie tot procesproduktie neemt de mate van storingen in het produktieproces regelmatig af. De korrelatie tussen beide deelvariabelen is, zoals vermeld, $r=.46$.

Variabele 20 kan een minimale warde van 2 (procesproduktie zonder storingen) en een maximale waarde van 7 (enkelstuksproduktie met in sterke mate storingen) bereiken.

Belangrijk is tenslotte nog te stipuleren dat de faktoranalyse ertoe leidde dat variabele 1 (technologie of routinisering) uit de replikatie-analyse uiteenvalt in een onrust- en een vrijheidaspekt.

De korrelaties tussen de twee oorspronkelijke variabelen 1 (routinisering) en 3 (onrust) en de nieuwe variabelen 20 (onrust, nieuwe versie) en 21 (vrijheid) zijn als volgt: 
variabele 1: routinisering

variabele 3: onrust

variabele 20: onrust (nieuwe versie)

varíabele 2l: vrijheid

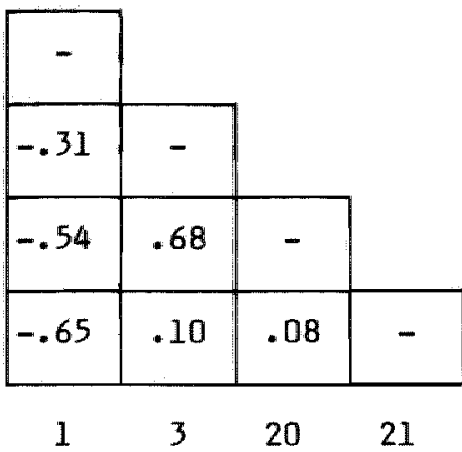

Men ziet hieruit ook dat routinisering zowel een onrust- als een vrijheid-komponent bezit. De oorspronkelijke variabele onrust heeft geen vrijheid-komponent en komt overeen met de nieuwe, meer valide onrust-variabele $(r=.68)$. Van de nieuwe versie mag dus niet verwacht worden dat deze geheel andere verbanden met het verzuim vertoont dan de oude versie. Toch is vervanging van de minder-valide door de meer-valide operationalisering waardevol. Tenslotte is het goed op te merken dat er bijna geen verband is tussen de variabelen 20 en $21(r=.08)$, hetgeen aanduidt dat het om twee verschillende bedrijfskenmerken gaat.

De hypothese van Philipsen, dat onrust - vanwege minder kans op instrumentele binding aan de werksituatie - gepaard gaat met een hogere verzuimfrekwentie wordt hier aangehouden. Niet door Philipsen (1969) vermeld onderzoek wijst namelijk in dezelfde richting. Melbin (1961) vond dat overplaatsingen en schemaveranderingen in ziekenhuizen frekwentieverhogend werkten, en Ekkers et al. (1980) stelden vast dat problemen bij produktiestaringen in 24 taakstudies samengingen met een relatief hoge verzuimfrekwentie en gemiddelde duur per geval. Alleen Houben (1981) vond geen relatie tussen produktiestoringen en verzuimindices; wel vond hij een verband tussen de frekwentie van taakonderbrekingen en het verzuimpercentage.

\section{Variabele 2l: Vrijheid in de taakuitvoering}

Zoals hierboven aangegeven, bestaat deze variabele uit twee onderdelen, namelijk de eerder gebruikte variabele vrijheid in werktempo en werkonderbrekingen en de nieuwe variabele duur van de arbeidscyclus. Deze laatste is tot stand gekomen door aan de 
bedrijfsleider te vragen wat de duur van de arbeidscyclus is van de werknemers van de grootste produktie-sfdelingen. Hierbij waren vier antwoordmogelijkheden beschikbaar (zie tabel 5.11). Door de procedure van weging vila de personeelsomvang van de afdelingen kwam een bedrijfsscore voor de duur van de arbeidscyclus tot stand (score 1, 2, 3 of 4). De totaal-score van variabele 21 kwam tot stand door optelling van de deelscores van beide subvariabelen. De theoretische variatiebreedte loopt van 2 (weinig of geen vrijheid en korte arbeidscyclus) tot $B$ (zeer veel vrijheid en lange arbeidscyclus). De korrelatie tussen vrijheid en duur arbeidscyclus is $\mathrm{r}=.38$.

Tabel 5.11 De verdeling van de bedrijven over de twee subvariabelen van variabele 21

\begin{tabular}{|c|c|c|c|c|c|}
\hline \multirow{2}{*}{ mete wan wrijheid } & \multicolumn{4}{|c|}{ duur van de arbeidscyolus } & \multirow{2}{*}{ totan } \\
\hline & $\begin{array}{l}\text { korter dan } \\
1 \text { mintste }\end{array}$ & $\begin{array}{c}1-5 \\
\text { minuten }\end{array}$ & $\begin{array}{c}6-10 \\
\text { mimuten }\end{array}$ & $\begin{array}{l}\text { langer dan } \\
10 \text { minuten }\end{array}$ & \\
\hline $\begin{array}{l}\text { weinig of geen vrijheld } \\
\text { enige vrijheid } \\
\text { temelijk weel vrijheid } \\
\text { zeer veel vaijheid }\end{array}$ & $\begin{array}{l}2 \\
5 \\
0 \\
0\end{array}$ & $\begin{array}{l}3 \\
9 \\
3 \\
0\end{array}$ & $\begin{array}{r}5 \\
14 \\
3 \\
1\end{array}$ & $\begin{array}{r}1 \\
19 \\
18 \\
2\end{array}$ & $\begin{array}{r}11 \\
47 \\
24 \\
3\end{array}$ \\
\hline totaal & 7 & 15 & 23 & 40 & 85 \\
\hline
\end{tabular}

Uit tabel 5.11 valt te konkluderen dat het verband tussen beide deelvariabelen in grote mate lineair is: hoe korter de arbeidscyclus, hoe minder de vrijheid in werktempo en werkonderbrekingen (alleen de twee middenkategorieën gaan gepaard met ongeveer dezelfde mate van vrijheid).

Onderzoek van onder anderen Lundquist (1958), Kilbridge (1961), Ford en Gillette (1969), Fried et al. (1972), Lawler et al. (1973), 0'Muircheartaigh (1975), Hackman en 0ldham (1976) en Algera (1980) heeft aangetoond dat takkvariatie, langcyclisch werk en autonomie in de taakuitvoering samengaat met een lagere verzuimf rekwentie.

Als hypothese kan dan ook geformuleerd worden dat een grotere mate van vrijheid en een langere arbeidscyclus meer kansen biedt op zelfontplooiing en dus op binding aan het werk en binding aan 
kollega's en leiding. Een hogere mate van binding wordt geacht gepaard te gaan met een lagere verzuimf rekwentle.

\section{Variabele 22: Grootte van de groepen in de produktie ('span of control" van de bazen)}

In variabele 9 werd de mate van uitgewerktheid van de organisatievorm aan de orde gesteld. Deze uitgewerktheid hing af van het aantal hiërarchische nivo's dat de organisatie kende, het aantal niet-leidinggevende produktiewerknemers en het aantal 'bazen'. Door middel van een formule werden deze drie gegevens tot één variabele samengesmeed. Bij een relatief groot aantal nivo's en/of bij een groot aantal bazen en een klein aantal uitvoerende produktiemedewerkers werd de organisatie uitgewerkt of steil genoemd.

Problematisch hierbij is echter dat, indien gevonden wordt dat een uitgewerkte organisatievorm samengaat met een relatief laag verzuim, niet duidelijk is of dat 'veroorzaakt' wordt door het aantal nivo's, door de grootte van de groepen of door de kombinatie van beide.

Ter bevordering van de duidelijkheid zal daarom de variabele 'grootte van de groepen op uitvoerend nivo in de produktiesektor' (ofwel: 'span of control' van de bazen) nog een keer als aparte variabele uitgetest worden in de vervolganalyse.

Deze deelvariabele is tevens gekozen omdat er eerder nogal wat onderzoek is gedaan naar de relatie groepsgrootte - verzuim. Ook uit niet door Philipsen vermeld onderzoek komt over het algemeen naar voren dat afdelings-/groepsgrootte positief samenhangt met het verzuimpercentage en/of de verzuimfrekwentie (onder anderen Bews, 1966; Schmidt, 1967; 0'Muircheartaigh, 1975; Rousseau, 1978; Markham, 1982b).

Zoals reeds bij variabele 9 beschreven werd, wordt de gemiddelde groepsgrootte per bedrijf bepaald door het aantal uitvoerende produktiewerknemers te delen door het aantal leidinggevenden op het laagste leidinggevend nivo in de produktie. In het geval dat er voorlieden in de produktie werkzaam waren, werden deze samen genomen met de hiërarchisch boven hen staande laag (meestal bazen, soms chefs of ploegleiders genaamd).

De gemiddelde grootte van de groepen zoals hier omschreven, varieerde tussen de bedrijuen van 4 tot 39. De gemiddelde groepsgrootte of "span of control" over alle 85 bedrijven bedroeg 13,4 
werknemers.

Tenslotte is van belang te melden dat er een korrelatie van $\mathbf{r}=$ . 85 bestaat tussen variabele 9 (organisatiestruktuur) en variabele 22 (groepsgrootte). Beide variabelen lijken dus sterk op elkaar en sensationele verschillen tussen belde, wat betreft de invloed op het verzuim, mogen dan ook niet verwacht worden. Toch heeft de toepassing van de nieuwe variabele groepsgrootte het voordeel dat duidelijkheid ontstat over deze variabele ten opzichte van het wat ingewikkelder begrip platheid of steilheid van de organisatiestruktuur.

Zoals Philipsen reeds uitvoerig heeft beschreven treft men in relatief grote groepen over het algemeen een hogere verzuimfrekwentie aan. De theoretische achtergrond hiervan is dat in grote groepen de kans op stabiele werkverhoudingen en de kans op bevredigende horizontale en vertikale relaties geringer geacht wordt.

\section{Variabele 23: De relatieve grootte van de personeelaafdeling}

Variabele 13 (ontwikkeling personeelsfunktie) trachtte door middel van een objektieve index de kansen op een kwalitatief en invloedrijk personeelsbeleid vast te stellen. Zoels dear echter werd beargumenteerd, voldeed deze meting miet meer In de huldige tijd. Als alternatief wordt daarom variabele 23 gebruikt. Deze betreft het aantal personeelsfunktionarissen per 1000 werknemers, afgerond op hele getallen. In deze index is dus gekorrigeerd voor bedrijfsgrootte. Onder personeel van de personeelsafdeling werden alle werknemers verstaan die zich met een of meer aktiviteiten betreffende het personeel bezighielden, inclusief sekretariële ondersteuning. Personen die zich bezighielden met personealsadministratie, medische zorg, bewaking, veiligheid en kantinewerkzaamheden werden echter uitgesloten. Personen die in deeltijd werken werden ook slechts voor het betreffende deel bij het totale aantal personeelsfunktionarissen gerelkend.

Het bleek, zoals reeds vermeld, dat elk bedrijf minstens één (volledige) personeelsfunktionaris in dienst had en dat het maximale aantal vijftien personen bedroeg. Het geniddelde was 4,9 personeelsfunktionarissen. De uiteindelijke warde op variabele 23 kon uiteenlopen van 3 tat 26 met een gemiddelde warde van 9,7 , hetgeen betekent dat er op elke 1000 werknemers gemiddeld 9,7 personeelsfunktionarissen beschikbaar zijn.

De hypathesen van variabele 13 kunnen voor deze variabele zonder 
wijziging overgenomen worden: hoe groter de personeelsafdeling hoe grater de kans dat zowel de verzuimf rekwentie als de verzuimduur aan de lage kant zullen zijn. Dok in recent onderzoek zijn overigens gelijksoortige konklusies te vinden. Dijkstre (1977) vond bijvoorbeeld een lager verzuimpercentage (partieel) bij grotere en goed geëquipeerde personeels- en medische afdelingen, en Ris (1978) vond korte verzuimduren (ook partieel) bij relatief grotere personeelsafdelingen.

Vermeldenswaard is tenslotte dat er een verband bestaat van $r=$ . 30 tussen variabele 13 (ontwikkeling personeelsfunktie) en variabele 23 (relatieve grootte personeelsafdeling). $\mathrm{Er}$ is dus een redelijk, maar geen sterk verband tussen de oude en de nieuwe operationalisering.

\section{Variabele 24: Tijd besteed aan personeelsbegeleiding en -zorg}

Dok variabele 14 (professionele personeelsbegeleiding) werd, vanwege zijn lage interne konsistentie en de geringe spreiding van de bedrijuen op drie van de vier deelvariabelen, niet goed bruikbaar geacht voor voortgezette analyses. Op andere wijze zal nu in deze leemte voorzien worden. Bij het materiaalverzamelen voor dit onderzoek is gebruik gemaakt van een verkorte versie van de aktiviteitenlijst die Buitendam (1979) ontwikkelde voor zijn onderzoek naar de struktuur en het funktioneren van personeelsafdelingen in de industrie. De hoofden van de personeelsafdelingen van de 85 bedrijven werd gevraggd op een aktiviteitenlijst met twaalf items door schatting aan te geven hoeveel procent van de totale beschikbare tijd van de gehele personeelsafdeling besteed werd aan deze twalf aktiviteiten. Hierbij werd uitgegaan van een standardweek. Samen met de kategorie 'rest van de aktiviteiten' diende het totaal van de lijst steeds op 100 procent uit te komen. Deze methode lijkt betrouwbaarder dan een methode waarbij eenvoudig gevraagd wordt of er aan één of meerdere van de twaalf aktiviteiten relatief veel of weinig tijd besteed wordt. Volgens de data van Buitendam konden de twaalf aktiviteiten in vier groepen ingedeeld worden: (a) sociale begeleiding, personeelszorg en takkgerichte opleiding; (b) werving/selektie, personeelsbeoordeling en positietoewijzing; (c) voorbereiding van de arbeidsvoorwarden, aktiviteiten rond de ondernemingsraad en kontakten met vakbonden; (d) taakstrukturering/werkoverleg, organisatie-ontwikkeling, en ontwikkeling en formulering van het sociaal beleid. 
In verband met het feit dat voor dit onderzoek gezocht werd naar een adekwate vervanging van het begrip professionele personeelsbegeleiding, lijken vooral de aktiviteiten uit de eerste groep van belang.

De twaalf aktiviteiten werden gefaktoranalyseerd; daaruit bleek dat de opdeling in de genoemde vier groepen/faktoren van Buitendam slechts gedeeltelijk terug te vinden was. Op basis van de faktoranalyse wan het huidige onderzoeksmateriaal zijn als indikatoren van het begrip professionele personeelsbegeleiding uiteindelijk gekozen sociale begeleiding en personeelszorg. Taakgerichte opleidingsaktiviteiten en takkstrukturering/werkoverleg laadden ook op dezelfde faktor, doch negatief, wasrdoor deze twee aktiviteiten buiten beschouwing zijin gelaten.

De twee te gebruiken aktiviteiten waren als volgt gedefinieerd:

- sociale begeleiding: individueel-gerichte personeelsbegeleiding, maetschappelijk werk, persoonlijke gesprekken, begeleiding van buitenlandse werknemers, etcetera;

- personeelszorg: huisvesting, kantine, jubilea, zlekenbezoek, antspanningsaktiviteiten, bedrijfsvervoer van het personeel, etcetera.

De onderlinge samenhang tussen de twee gekozen aktiviteiten is redelijk hoog $(r=.42)$. Zoals uit de vraagstelling duidelijk zal zijn, is de minimale score per aktiviteit a procent en de maximale score 100 procent. In de praktijk bleek dat de personeelsafdelingen van de 85 bedrijven gemiddeld 16.5 procent van hun tijd aan sociale begeleiding besteedden en 8.6 procent aan personeelszorg. Te zamen dus 25.1 procent van de totaal bestede tijd.

Nog enige woorden kunnen gewijd worden aan de verhouding tussen de 'oude' en de 'nieuwe' variabele personeelsbegeleiding.

De variabele professionele personeelsbegeleiding werd door Philipsen geoperationaliseerd met begrippen als selektie en beoordeling van personeel en met de aenwezigheid van medische voorzieningen. In feite gaat het daer om een kombinatie van personeelsbeheer en medische voorzieningen/keuringen. Men kan zich daervan afvragen of deze aktiviteiten wel bestempeld mogen worden als personeelsbegeleiding.

In dit onderzoek bleek dat de tijd besteed door de personeelsafdeling aan werving/selektie en aan personeelsbeoordeling (respektievelijk 11.1 en 4.4 procent van de tijd) negatief korreleerden 
met belde hierboven beschreven aktiviteiten op het gebied van begeleiding respektievelijk zorgverlening:

\begin{tabular}{|l|c|c|}
\cline { 2 - 3 } \multicolumn{1}{c|}{} & $\begin{array}{c}\text { sociale } \\
\text { begeleiding }\end{array}$ & $\begin{array}{c}\text { personeels- } \\
\text { zorg }\end{array}$ \\
\hline $\begin{array}{l}\text { werving / selektie } \\
\text { personeelsbeoordeling }\end{array}$ & $\begin{array}{r}r=-.06 \\
\mathrm{r}=-.08\end{array}$ & $\begin{array}{r}\mathbf{r}=-.24 \\
\mathbf{r}=-.16\end{array}$ \\
\hline
\end{tabular}

Deze gegevens ondersteunen de gedachte dat werving, selektie en personeelsbeoordeling niet onder personeelsbegeleiding gerangschikt zouden dienen te worden.

De in deze variabele 24 te gebruiken operationalisering van het begrip personeelsbegeleiding door middel van sociale begeleiding en personeelszorg lijkt meer valide. De korrelatie tussen variabele 14 en de nieuwe variabele 24 is negatief $(r=-.30)$, waruit blijkt dat beide variabelen - hoewel ze in principe voor hetzelfde begrip zouden moeten staan - iets anders blijken te representeren.

Tenslotte dienen de hypothesen met betrekking tot verzuim aan de orde gesteld te worden. Zoals saciale begeleiding en personeelszorg hier gedefinieerd zijn, zit in deze twee begrippen zowel het door Philipsen naar voren gehaalde element van aandacht voor het individuele ziektegeval, als het element van het ontwikkelen van sociale binding van het personeel aan het bedrijf. Dit laatste werd ook door Buitendam (1979) benadrukt. Omdat in variabele 24 de aspekten werving, selektie en keuring niet opgenomen zijn, zal er ook geen effekt verwacht mogen worden op de beperking van de verzuimnoodzaak, zoals dat bij variabele 14 wel verondersteld werd. Alles bij elkaar kan derhalve verwacht worden dat variabele 24 zowel een gunatige (verlagende) invloed zal hebben op de verzuimfrekwentie als op de verzuimduur (zie tabel 5.1).

Dijkstra (1977), Ris (1978) en Buitendam (1979) hebben de laatste jaren de effekten van aktiviteiten van personeelsafdelingen aan onderzoek onderworpen. De konklusies van de laatste twee auteurs zijn nilet relevant voor de hier behandelde variabele. Dijkstra vond echter dat begeleidingsaktiviteiten van de personeelsafdeling, zoals gesprekken en werkplekbezoek, frekwentiebeperkend werken. Voor verder empirisch onderzoek dat de hypothesen onder- 
steunt, wordt verwezen nar de publikatie van Philipsen (1969).

\section{Variabele 25: Slechte financieel-ekononische positie van het be- drijf}

De financieel-ekonomische positie van het bedrijf is door middel van drie deelvariabelen geoperationaliseerd. Alle drie gegevens zijn afkomstig uit het interview met de bedrijfsleider.

De eerste deelvariabele betrof een globale schatting van de omzet en de orderpositie van het bedrijf. Het antwoord kon in vier mogelijkheden verwoord worden: goed (score 1), redelijk (2), matig (3), slecht (4).

De tweede deelvariabele betrof de vraag of er in 1978 tot en met 1980 een personeelsstop had plaatsgevonden. Hierbij waren de antwoordkategorieën: in géén van de laatste drie jaren (score 1); alleen in $1978 \mathrm{en} /$ of 1979 , maar niet in 1980 (2); in 1980, inclusief eventueel $1978 \mathrm{en} /$ of 1979 (3).

De derde deelvariabele betrof de vraag of er in 1978 tot en met 1980 afzetproblemen waren geweest. Hierbij waren de antwoordkategorieën als bij de tweede deelvariabele.

Een bedrijf kon dus een minimale score van 3 hebben (goede omzet en orderpositie, en in geen van de drie jaren een personeelsstop of afzetproblemen), en een maximale score van 10 (slechte amzet en orderpositie met een personeelsstop en afzetproblemen in 1980). De interkorrelaties tussen de drie deelvariabelen waren als volgt:

1. omzet en orderpositie (slecht)

2. personeelsstop

3. afzetproblemen

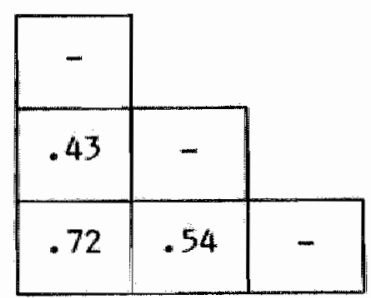

1 2

Cronbach's Alpha voor deze variabele bedraagt 0.79 , hetgeen zeer goed te noemen is.

Onderzoek, warbij de relatie tussen de financieel-ekonomische positie van het bedrijf en het verzulim van werknemers werd bestudeerd is helaas niet beschikbaar. Wel is er in een veertiental onderzoekingen aandacht besteed aan de relatie tussen enerzijds 
toekomstonzekerheid, de dreiging ontslagen te worden en de dreiging van bedriffssluiting, bedrijfsinkrimping, individuele arbeidsmarktpositie, en verzuim anderzijds (Cadourek, 1965; Owens, 1966; Handy, 1968; Hackman \& Lawler, 1971; Hershey, 1972; Dijkstra, 1974; Philipsen, 1977; Ris, 1978; Rushmore \& Youngblood, 1979; Wiersma, 1979; Van Dijkhuizen, 1980; Fitzgibbons \& Moch, 1980; De Jong et al., 1981; Nijhuis \& Soeters, 1982).

Uit deze, merendeels op individueel nivo geanalyseerde, studies valt te konkluderen dat gevoelens van dreiging of onzekerheid, of situaties die dreiging of onzekerheid zouden kunnen oproepen bij werknemers zowel positief, negatief als niet-signifikant met de verzuimmaten blijken samen te hangen. Met het verzuimpercentage en met de gemiddelde duur per geval blijkt het aantal positieve relaties echter relatief te overheersen.

Theoretisch is de inkonsistentie wel begrijpelijk, omdat bedrijfsproblemen gepaard kunnen gaan met zowel verzuimbeperkende als met verzuimstimulerende processen (Smulders et al, 1983a). Er zijn minstens twee elkar tegenwerkende mechanismen te onderscheiden als reaktie op een slechte financieel-ekonomische situatie in een bedrijf. Enerzijds kan deze situatie angst opwekken bij de werknemers om ontslagen te worden. Hierbij komt, dat er uit de pers en uit de bedrijfsinterviews aanwijzingen zijn dat een slechte bedrijfssituatie ook gepard gaat met sterkere sociale verzuimkontrole en verzekeringstechnische verzuimkontrole. De verzuimgelegenheid is dus laag bij een slechte bedrijfssituatie en een lage verzuimfrekwentie kan hiermee samengaan (zie bijvoorbeeld Dijkstra, 1974). Anderzijds is het goed voorstelbaar dat het bedriljf bij een slechte financieel-ekonomische positie en teruglopende produktie een overbezetting ean personeel begint te ontwikkelen. Dit teveel aan personeel kan verminderd worden door ontslag, door een personeelsstop, maar ook door minder aandacht voor het individuele ziektegeval, waardoor afvloeiingen via de Ziektewet en de WAO vergemakkelijkt worden. Zelfs een aktief beleid door personeelsafdelingen om mensen in de WAO in plaats van in de WW te 'helpen' wordt vaak verondersteld aanwezig te zijn. In de woorden van Wiersma $(1979, p .85)$ is er dan een "stilzwijgende toestemming van de betrokken autoriteiten, zoals de verzekeringsgeneeskundige, de bedrijfsarts en de personeelsdienst van het bedrijf, hopend op een sociaal acceptabele afvloeiing van minder valide werknemers". Dit kan betekenen dat ziekteduren in 
bedrijuen die het moeilijk hebben, relatief lang zijn (zie met name Wiersma, 1979, en De Jong et al., 1981). Samengevat: in dit onderzoek wordt ervan uitgegaen dat een slechte financieel-ekonomische positie van het bedrijf samengaat met een relatief geringe verzuimfrekwentie en relatief lange verzuimduren.

\section{Variabele 26: Werkloosheidspercentage van het rayon, waarin het bedrijf ligt}

Eerst de beschrijving van de variabele zelf. Nederland kent ongeveer 130 arbeidsbureaus, die elk gericht $z i j$ jn op de bevolking van één apart geografisch rayon. Van elk van deze 130 rayons werd door het Ministerie van Sociale Zaken het werkloosheidspercentage beschikbaar gesteld voor de tweede helft van 1979 en het gehele jaar 1980. Dit percentage is gedefinieerd als de gemiddelde geregistreerde arbeidsreserve voor mannen per rayon, uitgedrukt in procenten van de afhankelijke mannelijke beroepsbevolking.

Nu werd elk van de 85 onderzochte bedrijven het werkloosheidspercentage toegekend van het rayon warcin het gelegen was. Met opzet is een periode gekozen die loopt van medio 1979 tot aan eind 1980, omdat de invloed van de werkloosheid in de omgeving van een bedrijf op houdingen en gedragingen van de werknemers binnen dat bedrijf mogelijk een na-ijlingseffekt kan hebben. Omdat in dit onderzoek het ziekteverzuim van het jaar 1980 als uitgangspunt genomen wordt, is dus een na-ijlingseffekt van een half jaar ingebouwd door de werkloosheidscijfers betrekking te laten hebben op de periode van medio 1979 tot eind 1980.

Van werkloosheid in een regio, bedrijfstak of land wordt ook vaak aangenomen dat er een verzuimbeperkende werking van uitgaat (het gaat hier on een globaal effekt op de bedrijfsbevolking als geheel; het effekt behoeft uiteraard niet voor alle individuen even sterk te werken). De argumentatie voor dit verband komt meestal sterk overeen met die van de vorige variabele (financieel-ekonomische positie van het bedrijf).

Veertien bronnen zijn beschikbaar waarin de relatie tussen werkloosheid en ziekteverzuim onder de loupe is genomen: Behrend, 1953; Plummer en Hinkle, 1955; Crowther, 1957; Enterline, 1964; Van den Bergh en Ouwehand, 1965; Taylor en Pocock, 1969; Hedges, 1973; Doherty, 1979; Edwards, 1979b; Fenn, 1981; Thamas, 1981; Markham, 1982a, en Smulders et al., 1983a, 1983b. De analyse-een- 
heden in deze studies waren meestal bedrijven of bedrijfsgroepen. Hieruit blijkt dat ongeveer evenveel positieve als negatieve verbanden gevonden worden met het verzuimpercentage en/of de frekwentie. Fenn (1981) en Smulders et al. (1983a) rapporteren positieve verbanden met de duur; Smulders et al. (1983b) vermelden een negatief verband.

Het overheersende probleem hierbij is echter dat bij géén van deze studies de financieel-ekonomische positie van de bedrijuen waarin de werknemers werken, onder kontrole werd gehouden.

Zelfo als de financieel-ekonomische positie van een bedrijf wel onder kontrole wordt gehouden, kan men zich voorstellen dat er van de werkloosheid in de omgeving van een bedrijf nog een eigen extra-werking uitgaat op het verzuim van de werknemers. Op basis van een gelijksoortige argumentatie als onder de vorige variabele (financieel-ekonomische positie van het bedrijf) wordt die eigen bijdrage van het werkloosheidspercentage ook opgevat als frekwentie-beperkend en duur-verhogend.

\section{Variabele 27: De snelheid van de verzuimkontrole}

De personeelschefs van de 85 bedrijven werden uitwoerig geïnterviewd over de wijze van kontrole van het verzuim. Een deel van deze gegevens is reeds gebruikt bij variabele 16, waarbij het feit of de kontrole door het bedrijf zelf of door het GAK of de Bedrijfsvereniging wordt uitgevoerd, als deelvariabele werd opgevoerd.

Daarnaast werd getracht on de snelheid van de verzuimkontrole te schatten. Als de werknemers in de regel reeds op de eerste of tweede ziektedag gekontroleerd werden, meestal door een ziektewet- of lekekontroleur, werd score 3 (wel snel) toegekend. Indien de werknemers de eerste veertien dagen van hun ziekte niet bezocht en niet opgeroepen werden voor kontrole werd score 1 (niet snel) gegeven. In dergelijke gevallen kwam het nogal eens voor dat de werknemers een geprekodeerd vragenlijstje thuis gestuurd kregen waarop ze konden aangeven wat hen mankeerde, zonder dat dit overigens invloed had op de wijze van kontrole.

In alle, tussen de twee vitersten liggende, methoden werd score 2 (matig snel) toegekend. Deze score werd onder andere gegeven als er gedurende de eerste veertien ziektedagen selektief gekontroleerd werd.

Indien er voor produktie- respektievelijk administratief perso- 
neel een verschillend kontrolebeleid bestond, werd het beleid ten aanzien ven het produktiepersoneel gekodeerd.

De verdeling van de 85 bedrijven over snelheid van verzuimkontrole en verzekeringsvorm enerzijds en snelheid van verzuimkontrole en kontrole zelf/uitbesteed anderzijds, wordt in tabel 5.12 weergegeven.

Tabel 5. 12 De verdeling van de bedrijuen over varibbele 27 (anelheid verzuimkontro-

Le) en de twee subvariabelen van variabele 16 (verzekeringsvorm en kontrolevorm)

\begin{tabular}{|c|c|c|c|c|}
\hline \multirow{2}{*}{$\begin{array}{l}\text { verzekeringsvom respektieveli jik kontrolevorm } \\
\text { woor de } Z \text { i ektewet }\end{array}$} & \multicolumn{4}{|c|}{ snelheid verzulmkont role } \\
\hline & $\begin{array}{l}\text { nitet } \\
\text { gnel }\end{array}$ & $\begin{array}{l}\text { matig } \\
\text { snel }\end{array}$ & $\begin{array}{l}\text { wel } \\
\text { smel }\end{array}$ & toten 1 \\
\hline elgenr i si kodrager & 11 & 5 & 6 & 22 \\
\hline af diel ingskes & 6 & 3 & 12 & 21 \\
\hline omsileglid & 21 & 14 & 7 & 42 \\
\hline$\infty-\infty-m--\infty-\infty$ & -- & & & \\
\hline total & 38 & 22 & 25 & B5 \\
\hline 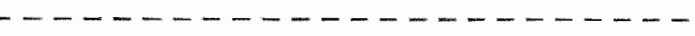 & $-\ldots$ & $-\ldots$ & $-\infty$ & $--m$ \\
\hline kant role geheel/gedeeltelijk zelf & 8 & 4. & 15 & 27 \\
\hline kontrole geheel door GAK of Bedrijfsverenighing & 30 & 18 & 10 & 58 \\
\hline 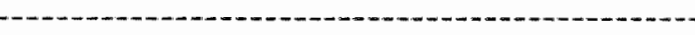 & & & & - \\
\hline totarl. & 38 & 22 & 25 & Q5: \\
\hline
\end{tabular}

Uit het bovenste gedeelte van de tabel is op te maken dat er een kromlijnig verband bestaat tussen de snelheid van verzuimkontrole en de verzekeringsvorm voor de Ziektewet. De afdelingakassen kontroleren relatief snel en de omslagleden en eigenrisikodragende bedrijuen relatief langzaam.

Verder blijkt er een tamelijk sterk verband $(r=-.36)$ tussen de snelheid van kontrole en het feit of deze al dan niet door het bedrijf zelf wordt uitgevoerd. Als dat laatste wel het geval is, geschiedt de kontrole sneller. Toch is dit verband weer niet zo sterk dat toevoeging van de variabele snelheid van kontrole geen $z$ in meer zou hebben naast hetgeen reeds in variabele 16 uitgedrukt is door het begrip band met de bedrijfsvereniging.

Er bestaat een zestiental onderzoeksbronnen waar in aspekten van verzuimkontrole in verband gebracht zijn met de hoogte van het 
verzulm: M. de Groot, 1954; Fortuin, 1955; Holthuis, 1961; De Boer, 1964; Handy, 1968; Philipsen, 1969; Taylor, 1969; J. de Groot, 1970; Baum en Youngblood, 1975; Nicholson, 1976; Baum, 1978; Ris, 1978; Winkler, 1980; Dalton en Perry, 1981; Fenn, 1981; Nijhuis en Soeters, 1982.

Uit de studies waarin men zich met het tijdstip van kontrole bezighoudt blijkt dat de snelheid van verzuimkontrole:

a. vooral duurbeperkend kan werken (Handy, 1968; J. de Groot, 1970);

b. ook de frekwentie van 1-dagsgevallen kan beperken, maar de frekwentie van iets langere gevallen kan doen toenemen. Door dit afruilingsmechanisme in de frekwentie dat optreedt door snelle verzuimkontrole (zie Nicholson, 1976) zal de relatie met de totale frekwentie zeer zwak of afwezig zijn.

Als veronderstelling kan dan ook uitgesproken worden dat de snelheid van de verzuimkontrole niet met de frekwentie en negatief met de gemiddelde duur per geval samenhangt. In het laatste geval gaat het on beperking van de afwezigheidsgelegenheid en meer aandacht voor het individuele ziektegeval, hetzij in "kontrolerende', hetzij in 'begeleidende' zin.

\section{Variabele 28: Aantal kontakten over zieke werknemers}

Een centraal begrip in de theorie van Philipsen ter verklaring van verschillen in verzuim tussen bedrijuen, is de aandacht die bedrijven schenken aan het individuele ziektegeval. Funktionarissen die hier in principe bij betrokken kunnen zijjn, zijn de personeelsfunktionaris, de bedrijfsleider, de baas/chef en eventueel ook de huisarts, verzekeringsarts en bedrijfsarts. Zij kunnen door overleg en beinvloeding de optimalisering van het tijdstip van herstelmelding van de zieke werknemer bevorderen.

Bij de vorige variabele, de snelheid van de verzuimkontrole, lag het aksent op het kontakt tussen de verzekeringsarts en/of de lekekontroleur en de zieke werknemer en daarmee op beperking van de verzuingelegenheid, en slechts in tweede instantie op aandacht voor het individuele ziektegeval.

Bij deze variabele gaat het niet om de 'officiële' kontakten krachtens de Ziektewet met de zieke werknemer, maar om de nietofficiële kontakten tussen de personeelschef, de bedrijfsleider 
en de verzekeringsarts over de situatie en positie van de zieke werknemer. De verzekeringsarts is bij deze variabele betrokken omdat deze - naast de twee respondenten in dit onderzoek - waarschijnlijk de meeste kontakten met vertegenwoordigers van het bedrijf heeft over zieke werknemers. De bedrijfsarts is nilet bij deze variabele betrokken omdat lang niet alle bedrijven daarmee te maken hadden.

Voor deze variabele is informatie van zowel de bedrijfsleider als de personeelschef gebruikt. Op basis van door Dijkstra (1977) ontwikkelde onderzoeksvragen werd an de eerste respondent de volgende vraag voorgelegd:

1. Komt het voor, dat $u$ kontakt opneemt met de personeelschef over zieke werknemers? (zelden of nooit, zo nu en dan, vaak; met respektievelijk scores $1,2,3$ ).

Aan de personeelschef werd het 'spiegelbeeld" van deze vraag voorgelegd:

2. Komt het voor, dat $u$ kontakt opneemt met de bedrijfsleider (of direkteur) over zieke werknemers? (zelfde antwoordmogelijkheden).

Bovendien werd aan de personeelschef gevraagd:

3. Komt het voor, dat $u$ kontakt opneemt met de verzekeringsgeneeskundige over zieke werknemers? (zelfde antwoordmogeli.jkheden).

De scores op deze drie vragen spreiden zeer bevredigend over de 85 onderzochte bedrijuen (zie Bijlage I), zodat eventuele lage korrelaties met andere variabelen niet aan geringe spreiding geweten kunnen worden.

De onderlinge verbanden tussen de drie beschreven variabelen $z i j n$ als volgt:

1. kontakt bedrijfsleider met personeelschef (BL)

2. kontakt personeelschef met bedrijfsleider (PZ)

3. kontakt personeelschef met verzekeringsarts (PZ)

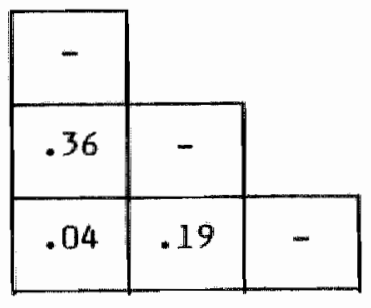

12

$B L=$ volgens bedrijfsleider; $P Z=$ volgens personeelschef 
Wit de matrix ziet men dat als de bedrijfsleider vaak kontakt opneemt met de personeelschef ower zleke werknemers, dit ook vaker geschiedt door de personeelschef met de bedrijfsleider $(r=.36)$. Ook blijkt de kontaktfrekwentie van de personeelschef met de bedrijfsleider signifikant te korreleren met die van de personeelschef met de verzekeringsarts $(\mathrm{r}=.19)$. De interkorrelaties tussen de drie beschreven deelvariabelen zijn echter niet erg sterk. $E_{r}$ is dus nog wel sprake van drie te onderscheiden aktiviteiten. Samenvoeging van de drie subvariabelen geeft een indikatie van de mate van aktiviteit die twee belangrijke bedrijfsfunktionarissen aan de dag leggen met betreklking tot zieke werknemers.

In termen van Dijkstra (1977) gaat het hier om een samenvoeging van zomel bedrijfsinterne als -externe ziektekontakten. Uit de vraagstelling valt overigens niet te konkluderen wat de inhoud van de kontakten is. Deze kan persoonlijke belangstelling als achtergrond hebben, kan van informatieve aard zijn, maar kan ook een wat politioneel-kontrolerend karakter hebben. Wat echter wel duidelijk is, is dat de kontakten van andacht voor de individuele verzuimer getuigen. Dat zou men het centrale thema van deze variabele kunnen noemen.

De total-score voor deze drie deelvariabelen werd bepaald door optelling van de scores op de drie vragen. De minimale score per bedrijf kon 3 bedragen (zelden of nooit kantakten) en de maximale score per bedrijf 9 (vaak kontakten over zieke werknemers).

In vier onderzoekingen is nagegaan of dit soort kontakten met en over zieke werknemers verzuimbeperkend kan werken. Dijkstra (1977) vond bij zijjn onderzoek in 56 sociale werkplaatsen, dat het aantal 'interne' ziektekontakten - tussen de personeelsafdeling, direktie, bedrijfsarts, baas en zieke werknemer - geen verband vertoonde met de gemiddelde duur per geval maar wel zwak negatief samenhing met de frekwentie. Ten tweede vond hij dat 'externe" ziektekontakten - tussen bedrijf en de huisarts, de verzekeringsarts, de specialist, en anderen - niet samenhingen met de frekwentie, maar positief (1) met de gemiddelde duur per geval. Het gaat hier steeds om partiële relaties.

Wat de laatste relatie betreft, meent Dijkstra dat het mogelijk is dat men in bedrijven met veel langdurige ziekteverzuimgevallen extra aktief wordt en genoodzaakt is met veel instanties kontakt te onderhouden. Dok is mogelijk dat de GMD, die zich met WAO-beoordelingen bezighoudt, een bedrijf dan noodzaakt tot veel intern 
overleg/kontakten. Dit zou betekenen dat er hier sprake is van een omdraaiing van oorzaak en gevolg: de ziektekontakten zijn dan het gevolg van het aantal lange zlekteverzuimgevallen.

Een andere verklaring, meent Dijkstra, zou kunnen zijn dat kontakten tussen het bedrijf en deskundigen de laatste kategorie aanleiding geeft tot een intensiever therapie, die zorgverhogend en tevens duurverlengend kan werken. Mogelijk is hier dus sprake van onbedoelde (duurverlengende) effekten van kontakten over zieken met deskundigen.

Ris (1978) vond in zijn onderzoek in 39 produktiebedrijven geen signifikante partiële verbanden tussen het aantal kontakten van de personeelsafdeling met leiding, werknemer zelf, verzekeringsarts en huisarts, en de verzuimf rekwentie/verzuimduur.

In het zogenaamde WAO-determinantenonderzoek (De Jong et al., 1981) onder 2414 werknemers werd onderscheid gemaakt tussen overleg over zieken tussen de personeelschef, de bedrijfsarts en de afdelingschef enerzijds en het aandacht-schenken aan zieken door middel van een bezoek of een attentie enderzijds. Interessant is dat de eerste variabele zwak positief en de tweede partieel negatief korreleert met de kans op een 5-maands-ziektegeval. Blijkbaar zijn dit duidelijk te scheiden aktiviteiten.

Ten vierde konstateerden Nijhuis en Soeters (1982) bij hun onderzoek in 51 industriële en niet-industriële Zuidlimburgse organisaties bij drie te onderscheiden personeelskategorieën, dat hun somscore met betrekking tot kontakten over zieke werknemers meestal geen relatie vertoonde (na partialisering) met de verzuimfrekwentie en de verzuimduur. Wel vonden ze een positief (1) verband met WAO-instroom, hetgeen ook weer een gevolg kan zijh van de aandacht die WAO-gevallen eisen.

De resultaten van deze vier studies zijn niet gunstig voor de veronderstelde verzuimbeperkende werking van het aantal interne en externe kontakten met/over zieke werknemers.

Toch wordt in navolging van de gedachtengang van Philipsen de hypothese opgesteld dat kontakten over zieke werknemers door de personeelschef, de bedrijfsleider en de verzekeringsarts samengaan met relatief korte ziekteverzuimgevallen, omdat door de aandacht voor het individuele ziektegeval wachttijden bij medische instanties verkort worden en bepalde klachten snel gesignaleerd. In andere woorden is het veronderstelde effekt: voorkoming van 
vertraging van het tijdstip van herstelmelding.

\section{Variabele 29: Percentage buitenlandse produktiewerknemers}

Het aantal buitenlandse werknemers in Nederland is sinds het midden van de zestiger jaren sterk toegenomen. In 1964/65 waren er nog maar circa 30.000 werknemers uit de zeven mediterrane werwingslanden (exclusief Italië) in Nederland werkzaam, terwijl deze kategorle in 1978 circa 105.000 werknemers omvatte. Philipsen (1969, p. 25I) kon dan ook nog schrijven dat slechts enkele van de bedrijuen grote groepen buitenlandse arbeiders in dienst hadden.

Ten tijde van het replikatie-onderzoek was deze situatie sterk veranderd. Bij de 85 bedrijven was gemiddeld 17.6 procent van het produktiepersoneel van buitenlandse nationaliteit. Slechts zeven bedrijven hadden géén buitenlandse werknemers in dienst en bij echt bedrijven bedroeg het percentage buitenlandse produktiewerknemers meer dan 40 procent. Zoals uit het bovenstaande blijkt, is per bedrijf dus niet het percentage buitenlandse werknemers van het totale personeelsbestand berekend, maar is het percentage genomen van het produktiepersoneel (inclusief technische diensten). Dit geschiedde om de vergelijking tussen de bedrijven zo zuiver mogelijk te maken.

Er werden twaalf bronnen gevonden waarin verslag werd gedaan van onderzoek over de verschillen tussen autochtonen en buitenlandse werknemers met betrekking tot verzuim: Jardillier, 1962; Van Erp, 1967; Schmidt, 1967; Vertin, 1967; Schmoll, 1973; Bellt, 1978; Alezra et al., 1979; Edwards, 19798; Baker en Pocock, 1982; Kruidenier, 1982; Nijhuis en Soeters, 1982; Peeters et al., 1982. Hoewel de resultaten voor wat betreft de verzuimf rekwentie iets geprononceerder zijn den voor de verzuimduur per geval en er uiteraard verschillen zi.jn tussen nationaliteiten, is het globale beeld wel duidelijk: buitenlandse werknemers vertonen een hoger verzulim dan autochtone werknemers. Voorts vertonen Turken en Marokkanen over het algemeen hogere cijfers dan Spanjaarden en Italianen. Ook woonomstandigheden (al dan niet in een woonoord) en gezinsomstandigheden (al dan niet met vrouw en kinderen) spelen een rol in het verzuimpatroon (Belt, 1978).

Wat betreft de gezondheid noemt $V_{a n} E_{\Gamma P}$ (1967) onder andere het méér voorkomen van tbc, maagzweren en verkeersongelukken bij buitenlandse werknemers. Andere elementen, die door meerdere auteurs 
naar voren gehald worden, on het mindere welbevinden van buitenlandse werknemers in een vreend land te verklaren $z 1 j$ in de taalproblemen, klimaat, arbeidstempo, opvattingen wat betreft de waerdering van werkrelaties en gezinssituaties, alsmede medikelisering van psychische problemen en het verstrikt raken in het "medisch kanaal".

Op basis van deze gegevens kan verondersteld worden dat de hogere verzuimfrekwentie en de langere gemiddelde ziekteduren van buitenlandse werknemers te maken hebben met (a) een grotere objektieve en subjektieve verzuimnoodzaak, (b) een geringere instrumentele en sociale binding aan de werksituatie, en (c) een geringere organisatie-oriëntatie dan bij Nederlandse werknemers het geval is. Deze hypothesen zijn ook in tabel 5.1 (p. 72-73) aangegeven.

\section{Variabele 30: Sociaal leiderschap}

Aan leiderschap valt een drietal aspekten te onderscheiden. Ten eerste kan men spreken over leiderschapsaktiviteit. Dit heeft betrekking op de frekwentie warmee de leider zich tot zijn ondergeschikten wendt, dus de mate van bemoeienis. Deze frekwentie kan toenemen van 'general' tot 'close supervision'.

Ten tweede kan men aan leiderschap de mate van eenzijdigheid in de richting van kommunikatie onderscheiden. Er kan sprake zijn van leiderschap dat eenzijdig van boven naar beneden wordt uitgeaefend (autoritair) en van leiderschap waarbij ook "inspraak" van beneden af plaats kan winden (demokratisch). Deze mate van eenzijdigheid van het leiderschap is met variabele 11 getracht te meten.

Ten derde kan men zich bij leiderschap afvragen welke funkties het verricht voor het funktioneren van de onderschikten. In de vijftiger jaren is daar in de Verenigde staten voor het eerst aandacht aan besteed door medewerkers van de Ohio State University (Stogdill \& Coons, 1957). Philipsen (1965) heeft, op basis van het Amerikaanse onderzoek, getracht na te gaan of de resultaten ook in Nederland gevonden konden worden. Dit was inderdaad het geval. De belangrijkste twee faktoren bleken sociaal leiderschap en instrumenteel leiderschap te zijn. De eerste faktor meet of de leidinggevende open staat voor kommunikatie, of hij aanmoedigingen en beloningen hanteert in plats van straffen en dreigementen en of hij de afstand tot $z i j n$ ondergeschikten verkleint. 
De instrumentele faktor meet of de leidinggevende aandacht heeft voor de arbeidsprestaties en of hij het werkproces struktureert volgens vastgestelde regels.

De verkorte versie van de vragenlijst die beide leiderschapsfunkties meet - tweemal drie items - werd an de bedrijfsleider en aan de personeelschef voorgelegd. De vragenlijst bestond uit zes uitspraken waarop men met vaak (score 3), soms (2) of zelden of nooit (1) kon antwoorden. De respondenten werd gevraagd aan het feitelijk leidinggevend gedrag te denken en niet aan hoe het eventueel zou moeten zijn. De zes uitspraken waren de volgende:

\section{Sociaal leiderschap}

1. De gemiddelde baas (in de produktie-afdelingen) zorgt ervoor dat zijn mensen zich op hun gemak voelen als ze met hem praten (A).

2. De gemiddelde baas geeft uiting aan zijn waardering als een van $z i j n$ mensen goed gewerkt heeft (B).

3. De gemiddelde baas is vriendelijk en staat open voor al zijn personeel (A).

$A=$ Afstand-aspekt; $B=$ Beloningen-aspekt.

\section{Instrumenteel leiderschap}

1 . De gemiddelde baas staat erop dat alles volgens vastgestelde regels gebeurt $(R)$.

2. De gemiddelde baas spoort langzame werkers an tot grotere inspanning $(\mathbb{P})$.

3. De gemiddelde baas let erop dat iedereen zijn uiterste best $\operatorname{doet}(P)$.

$R=$ Regels-aspekt; $P=$ Prestatile-aspekt.

De vragen werden niet in bovenvermelde volgorde an de respondenten voorgelegd om vertekening te voorkomen. Dok de achterliggende aspekten werden uiteraard niet vermeld.

In het Amerikaanse leiderschapsonderzoek en in het replikatie-onderzoek van Philipsen (1965) werden deze vragen voorgelegd aan ondergeschikten die op deze wijze hun baas/chef konden beschrijven. Alleen Philipsen (1965, p. 168) heeft de verkorte versies ook voorgelegd aan bedrijfsleiders om hun ondergeschikte bazen te typeren. Zonder details te noemen, meldt hij dat het sociaal leiderschap en het instrumenteel leiderschap ook op die manier als aparte faktoren naar voren komen. 
In dit onderzoek zijn de vragen ter beschrijuing van het leiderschapsgedrag van de bazen in de praduktie voorgelegd aan een bovengeschikte (de bedrijfsleider) en aan een interne beoordelaar (de personeelschef). Hier beoordelen dus twee personen het leiderschapsgedrag van gemiddeld 22 bazen in de produktie-afdelingen. Men zou hier kunnen tegenwerpen dat leiderschapsgedrag iets zeer individueels is, en dat het vragen naar een mening over gemiddeld gedrag daarom onjuist is. In onderzoeksliteratuur wordt echter aangenomen dat er in een bedrijf zolets bestaat als een leiderschapsklimaat. Guest (1962) toonde bijvoorbeeld aan dat een dergelijk klimaat $z i c h$ van bovenaf ontwikkelt door middel van een 'doorsijpelingsmechanisme' van leiderschapsgedrag. Dok Cassee (1967) heeft dit aannemelijk gemaakt voor het sociaal leiderschap in een ziekenhuisorganisatie. Dit alles was er anleiding toe om de hier gebruikte techniek van leiderschap(sklimat)-meting in principe als valide te beschouwen. Betrouwbaarheidsmetingen zullen mog iets meer licht op de validiteit van de aanpak kunnen werpen.

\section{Sociaal leiderschap}

1. stelt mensen op hun gemak (A)

2. geeft uiting aan warrdering

(B)

3. is vriendelijk en staat open (A)

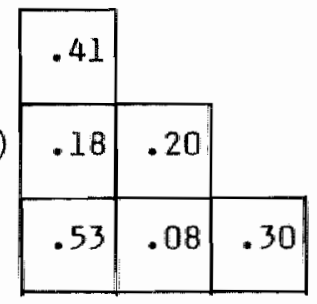

\section{Instrumenteel leiderschap}

1. staat op vastgestelde regels (R)

2. spoort langzame werkers aan

3. Let op best doen (P)

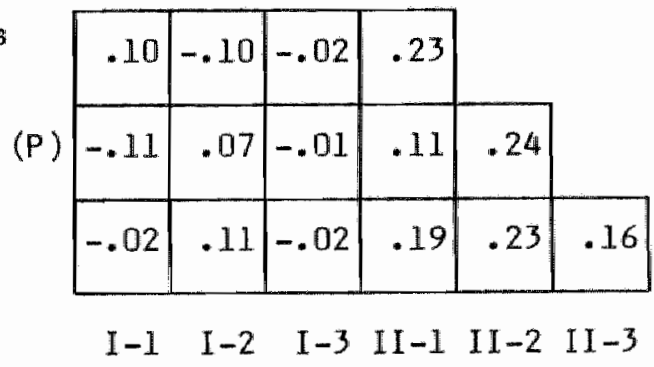

Hierboven worden de korrelatiekoëfficiënten gegeven tussen de zes items, gebaseerd op de somscores van beide respondenten. Op de diagonaal staan de korrelaties vermeld tussen de antwoorden van beide respondenten op dezelfde items. 
De achterliggende aspekten (afstand verkleinen, beloningen hanteren, regels toepassen en prestatie stimuleren) $z 1 j n$ achter de zes uitspraken vermeld.

Allereerst zlet men uit de koëfficlënten op de diagonael dat de bedrijfsleider en de personeelschef het met betrekking tot het leiderschapsgedrag van de bazen signifikant met elkaar eens waren, maar dat de korrelaties niet erg sterk genoemd kunnen worden (tussen .16 en .41).

Uit de korrelaties tussen de items valt te zien dat bij het sociaal leiderschap beide uitspraken die het verkleinen van afstand indiceren ( 1 en 3), sterk korreleren en dat de tweede variabele over het uiten van waardering - hlier wat buiten valt. Iets derge$1 i j k s$ doet $z i c h$ ook voor bij het instrumenteel leiderschap, waarbij de beide items die prestatie-stimulering indiceren het sterkst korreleren $(\mathrm{r}=.23)$.

De data zijn ook nog eens door middel van tweevoudige variantieanalyse op betrouwbarheid bestudeerd. Hieruit bleek dat de scores op alle zes items signifikant verschilden tussen de bedrijven, hetgeen belangrijk is voor de verdere analyse. Onderstaande tabel laat de resultaten van de zes variantie-analyses - één per item - zien.

Tabel 5.13 de gemiddelde scores van beide respondenten op de zes subvariabelen van de variabelen 30 en 31 en de resultaten van de toetsing van de verschillen tussen de bedrijuen en tusisen de respondenten

\begin{tabular}{|c|c|c|c|c|}
\hline subvariebulen & $\begin{array}{l}\text { gentddelde } \\
\text { score van de } \\
\text { bedrijfs- } \\
\text { lelders }\end{array}$ & $\begin{array}{l}\text { gemiddelde } \\
\text { gcore van de } \\
\text { personerels- } \\
\text { chefs }\end{array}$ & $\begin{array}{l}\text { signifikantie } \\
\text { van de ver- } \\
\text { schillen tussen } \\
\text { de bedrijuen }\end{array}$ & $\begin{array}{l}\text { signifikantie } \\
\text { van de ver- } \\
\text { schillen tussen } \\
\text { de respondenten }\end{array}$ \\
\hline \multicolumn{5}{|l|}{ soctall leiderschap } \\
\hline $\begin{array}{l}1 \text { stelt mensen op hum } \\
\text { gemak }\end{array}$ & 2.73 & 2.49 & .0001 & .001 \\
\hline $\begin{array}{l}2 \text { geeft uiting aan } \\
\text { weardering }\end{array}$ & 2.21 & 2.08 & .03 & .07 \\
\hline $\begin{array}{l}3 \text { is vriendelijk en } \\
\text { gtat opert }\end{array}$ & 2.56 & 2.40 & .003 & .02 \\
\hline \multicolumn{5}{|l|}{$\begin{array}{l}\text { inst rumented leider- } \\
\text { schap }\end{array}$} \\
\hline $\begin{array}{l}1 \text { staat op vestge- } \\
\text { atelde regels }\end{array}$ & 2.39 & 2.46 & .02 & .63 \\
\hline $\begin{array}{l}2 \text { spoort langzame } \\
\text { werkers ann }\end{array}$ & 2.38 & 2.39 & .01 & .86 \\
\hline 3 let op best doen & 2.33 & 2.36 & .06 & .64 \\
\hline
\end{tabular}


Ook ziet men uit de rechter kolom van de tabel det beide respondenten met betrekking tot het instrumenteel leiderschap niet signifikant van mening verschillen. Dit betekent dat de bedrijfsleiders en personeelschefs ongeveer hetzelfde deel van de antwoordschaal gebruikten om hun mening tot uitdrukking te brengen. Met betrekking tot sociaal leiderschap ligt de zaak echter anders. Daar blijkt dat de personeelschefs systematisch meer het 'kritische' deel van de antwoordschaal gebruikten om hun mening over de leiding van de bazen tot uitdrukking te brengen. Een dergelijk verschijnsel werd reeds eerder aangetroffen bij de werkomstandigheden (variabele 5) en bij delegatie (variabele 7). Het feit dat de twee groepen respondenten twee verschillende delen van de antwoordschaal gebruiken met betrekking tot sociael leiderschep wil overigens niet zeggen dat beide repondenten het over de situatie in hun bedrijven niet eens zijn; ze verschillen alleen gradueel van mening.

De total-score voor sociaal leiderschap ontstond uit sommering van de scores van de bedrijfsleider en de personeelschef op alle drie items. De minimumscore was dus 6 (zelden of nooit op alle drie items) en de maximale score kan 18 bedragen (vaak op alle drie items).

De interne konsistentie van sociaal leiderschap, gebaseerd op de drie somscores, is hoger dan van instrumenteel leiderschap (Cronbach's Alpha's respektievelijk 0.53 en 0.39 ). Voorts is de korrelatie tussen beide instrumenten $r=-.01$, hetgeen aantoant dat het inderdaad om twee verschillende leiderschapsfunkties gaat, die geen verband met elkaar vertonen.

Hoewel er zeer veel onderzoeksliteratuur over leiderschap bestaat, is er over de twee specifieke leiderschapsfunkties en verzuim minder beschikbar. Als ook de literatur in de beschouwing betrokken wordt waarin sociaal leiderschap niet precies op de wijze van de genoemde Ohio-studies geoperationaliseerd werd, maar door middel van begrippen als werknemer-gericht, menseli.jke relaties, saciale ondersteuning, luisteren, aandacht voor gevoelens, respekt, positieve sankties, etcetera, den zijn de volgende achttien bronnen beschikbaar: Metzner en Mann, 1953; Fleishman et al., 1955; Argyle et al., 1958; Lundquist, 1958; Jardillier, 1962; Cooper, 1966; Cassee, 1967; Student, 1968; Gerstenfeld, 1969; Ronan et al., 1973; Schmidt-Brasse en Neuberger, 1973; Wexley en Nemeroff, 1975; Johns, 1978; Rushmore en Youngblood, 1979; 
Van Dijkhuizen, 1980; Fitzgibbons en Moch, 1980; Pascale en Maguire, 1980; Szilagyi, 1980. Uit deze onderzoeksliteratuur blijkt in het merendeel van de gevallen dat soclaal leiderschap verzuim(frekwentie)-beperkende effekten theeft.

Zonder veel terughoudendheid kan dus de hypothese geformuleerd worden dat sociaal leiderschap, door het versterken van de sociale binding van de werknemers an de organisatie, met de verzuimfrekwentie een negatief verband zal vertonen.

\section{Variabele 31: Instrumenteel leiderschap}

Het meeste wat over deze variabele te zeggen valt, is reeds bij de vorige variabele vermeld. Bij het sociaal leiderschap ging het on kommunikatie, aanmoediging en het verkleinen van de afstand met de ondergeschikten; bij instrumenteel leiderschap gaat het om de aandacht voor de arbeidsprestatie en het struktureren van het werkproces.

De operationalisering van instrumenteel leiderschap en kanttekeningen bij de betroumbarheid van het meetinstrument zijn ook bij de vorige variabele reeds vermeld. Hier rest nu om, op basis van de onderzoeksliteratuur, een hypothese op te stellen met betrekking tot de relaties met de ziekteverzuim-maten. Het merendeel van de, in onderzoek met betrekking tot produktie- en prestatiegericht leiderschap, gevonden relaties bleek niet-signifikant te zijn (Fleishman et al., 1955; Argyle et al., 1958; Lundquist, 1958; Cooper, 1966; Cassee, 1967; Ronan et al., 1973; SchmidtBrasse en Neuberger, 1973; Johns, 1978). Eén of meer negatieve relaties tussen instrumenteel leiderschap of aspekten dearvan en het verzuimpercentage en/of de verzuimfrekwentie werden gevonden door Metzner en Mann (1953), Cooper (1966), Cassee (1967) en Johns (1978). En tenslotte troffen Fleishman et al. (1955) en Lundquist (1958) ook twee positieve relaties in hun materiaal aen.

Deze resultaten lijken tegenstrijdig. Ze zouden echter interpreteerbaar worden indien de relatie van instrumenteel leiderschap met de verzuimfrekwentie kromlijnig (U-vormig) zou zijn. Gezien het linealre karakter van korrelatie-rekening komt een kromlijnig verband namelijk als niet-signifikant naar voren; de niet-signifikante verbanden zouden dus kromlijnig geweest kunnen zijn. De positieve en negatieve verbanden zouden dan ontstaan kunnen $z i j n$ in situaties waarin de gemeten warden van het instrumenteel 
leiderschap sterk aan de linker- of sterk aan de rechterkant van de schaal lagen.

Dok uit theoretisch oogpunt is een kromlijnig verband verdedigbaar. Bij instrumenteel leiderschap gaat het namelijk per definitie om aandacht voor de arbeidsprestaties van de werknemers door aansporing en kontrole en om het struktureren van het werkproces door het toepassen van regels. Een extreem hage mate van aensporing, kontrole en regeltoepassing zou autoritaire trekken kunnen krijgen en daarmee verzuimbevorderend kunnen zijn. Een 'gemiddelde' mate van aansporing, kontrole en regeltoepassing kan echter geacht worden rust en voorspelbaerheid te brengen in het werk, hetgeen de instrumentele binding bevordert en het verzuim kan beperken. Tenslotte is het bij bijna of geheel ontbreken van deze elementen in de werksituatie voorstelbaar dat de binding aan het werk en de prikkel om aanwezig te zijn sterk vermindert of zelfs afwezig is.

Kortom, in dit onderzoek wordt de relatie tussen instrumenteel leiderschap en de verzuimfrekwentie verondersteld kromlijnig (Uvormig) te zijn.

Variabele 32: Invloedsverschil tussen leiding en uitvoerenden in de produktie

Vertikale relaties in organisaties - de relaties tussen leiding en uitvoerenden - kunnen niet alleen gekenmerkt worden door de mate van demokratisch/autoritair leiderschap, delegatie van verantwoordelijkheid, sociaal en instrumenteel leiderschap, maar ook door de mate van invloed die de diverse hiërarchische lagen hebben op te nemen beslissingen.

De verhouding tussen bovengenoemde variabelen dient nu eerst weergegeven te worden.

Demokratisch/autoritair leiderschap (variabele 11) wordt sterk bepaald door de mate van 'inspraak' van de ondergeschikten in de beslissingen en het handelen van de bovengeschikte. Maar het aksent ligt hierbij behalve op invloed/inspraak, ook op al dan niet tweezijdige kommunikatie. Demokratisch leiderschap is dus niet simpelweg gelijk te stellen met een geringe mate van invloedsverschil tussen leidinggevenden en niet-leidinggevenden.

De hier te bespreken variabele invloedsverschil kan bovendien nog vergeleken worden met de variabele delegatie van verantwoorde- 
lijkheid. Bij deze laatste ligt het aksent op de bevoegdheden die niet-leidinggevenden van hun baes gedelegeerd hebben gekregen en op het al dan niet zelfatandig kunnen handelen. Het verschil met de variabele invloedsverschil zit in het feit dat een werknemer die weinig of geen verantwoordelijkheden gedelegeerd heeft gekregen en dus weinig of niet zelfstandig kan handelen, in principe nog wel de mogelijkheid geboden kan warden om invloed uit te oefenen op beslissingen die op een hoger nivo genomen worden. Deze verschillen nemen overigens niet weg dat er wel substantiële avereenkomsten zullen bestaan tussen de variabelen 7 (delegatie), 11 (demokratisch leiderschap) en 32 (invloedsverschil).

Het meetinstrument is gebaseerd op twee eerder gebruikte instrumenten, namelijk de Control-graph van Tannenbaum (1968) en de centralisatieschasl van de Engelse Aston-groep (Pugh et al., 1968), en het idee voor het hier te gebruiken instrument werd in feite geformuleerd door koot (1981).

Bij de Control-graph wordt de invloed gemeten van de verschillende hiërarchische lagen in een organisatie op 'de algemene gang van zaken', volgens de uitvoerende medewerkers. Bij de centralisatieschaal wordt de invloed gemeten van de verschillende hiërarchische lagen in de organisatie, volgens de direktie, op 37 beleidsonderwerpen/-beslissingen op het terrein van produktie, verkoop, financiën, algemene zaken en personele zaken. Het gaat hierbij om beleidszaken die de totale organisatie betreffen en bovendien meestal niet om zaken waarin de uiltvoerende medewerkers vaak betrokken worden.

Bij de Contral-graphmethode krijgt elke hiërarchische laag een elgen cijfer, lopend van bijvoorbeeld 0 (geen invloed) naar 5 (zeer veel invloed). Bij de centralisatieschaal $\mathrm{kr} i j g t$ elk van de 37 beleidsitems één cijfer, namelijk dat van de laagste hiërarchische laag die beslissingsbevoegdheid heeft met betrekking tot het betreffende item.

De Control-graph geeft dus van een groot aantal werknemers de gemiddelde perceptie weer van de algemene gang van zaken, terwijl de centrallsatieschaal geacht wordt inzicht te geven in de delegetie van formele bevoegdheden ten aanzien van een reeks beleidspunten, volgens de topmanager van de organisatie.

Koot (1981) heeft onderzoek gedaan met de centralisatieschaal en 
heeft daarbij een groot aantal technische mankementen aan het instrument vastgesteld. Het in het hier beschreven onderzoek te gebruiken meetinstrument on de verdeling van invloed op beslissingen vast te stellen poogt enige aspekten van zowel de Controlgraph als de centralisatieschaal te kombineren en technische mankementen zoveel mogelijk te vermijden.

Aan zowel de bedrijfsleider als de personeelschef van de 85 bedrijuen is een tiental onderwerpen voorgelegd, waarover zo nu en dan in de produktiesektor van elke organisatie beslist moet worden. Met opzet werden onderwerpen gekozen waarop uitvoerende medewerkers (soms) ook (enige) invloed kunnen uitoefenen en die voor hun dagelijks funktioneren belangrijjk zullen zijn (zie de onderwerpen in tabel 5.14). Beide respondenten werd vervolgens gevraagd aan te geven hoeveel invloed respektievelijk de concernleiding, de leiding van de orgenisatie zelf, de leiding van de tatale produktie, de 'bazen' en de uitvoerende produktienedewerkers op deze tien onderwerpen doorgeans hebben. Men kon zijn antwoord aanduiden met een cijfer van 1 tot en met 5 voor respektievelijk geen invloed (1), weinig invloed (2), nogal wat invloed (3), veel invloed (4), zeer veel invloed (5).

Omdat vijf van deze tien onderwerpen niet voldeden vanwege betrouwbaarheidsredenen, zijn uiteindelijk vijf onderwerpen overgebleven. Bovendien zijn voor de uiteindelijke index alleen de scores gebruikt van drie van de vijf nivo's, namelijk van de produktieleiding, de "bazen" en de uitvoerende produktiemedewerkers. Dit geschiedde om zoveel mogelijk de invloedsverdeling in de produktiesektor bloot te leggen.

Tabe: 5.14. De gemiddelde invlaed die bejde respandenten te zamen an drie hieranchische lagen tokenmen op vijf omderwerpen

\begin{tabular}{|c|c|c|c|}
\hline invloed-variabelen & $\begin{array}{l}\text { produktie- } \\
\text { lelding }\end{array}$ & bazen & $\begin{array}{l}\text { uit voerende } \\
\text { produkt ie- } \\
\text { medewerkers }\end{array}$ \\
\hline 1 werktempo uitvoerende produkt iemedewerkers & 3.04 & 3.90 & 3.46 \\
\hline 2 werkmethoden witwoerende produkt i emedewerkers & 3.33 & 3.69 & 2.73 \\
\hline $\begin{array}{l}3 \text { wernieuwen gereedschap uitvoerende produktie- } \\
\text { medewerkers }\end{array}$ & 3.04 & 3.89 & 2.98 \\
\hline 4 bevordering uitwaerende produktiemediewerkers & 3.66 & 3.40 & 1.50 \\
\hline $\begin{array}{l}5 \text { wrije dag krijgen uitvoerende produktiemede- } \\
\text { werkers }\end{array}$ & 1.78 & 4.30 & 2.57 \\
\hline
\end{tabular}


Men ziet uit tabel 5.14 dat de produktieleiding de meeste invloed wordt toebedacht, als het om de bevordering van uitvoerende produktiemedewerkers gaat. De bazen bepalen volgens beide respondenten het sterkst het werktempo, de werkmethoden en het vernieuwen van het gereedschap; zo ook wanneer een uitvoerende produktiemedewerker een vrije dag kan krijgen. De uitvoerenden zelf wordt verhoudingsgewijs de meeste invloed toegedacht als het om hun eigen werktempo gaat.

De uiteindelijke score op variabele 32 werd per bedrijf bepaald door de scores, door beide respondenten toegekend aan de produktieleiding èn aan de bazen, op de vijf onderwerpen op te tellen en daarvan de scores toegekend aan de uitvoerende produktiemedewerkers vanaf te trekken. De maximale score per bedrijf (beide respondenten te zamen) kon $2 \times 5 \times(10-1)=90$ bedragen (zeer grote invloedsverschillen ten nadele van de laagste laag) en de minimale score kon $2 \times 5 \times(2-5)=-30 \mathrm{zijn}$ (maximale invloed voor het laagste nivo). De gemiddelde verschilscore voor alle 85 bedrijven te zamen bedroeg 41.6 (zie tabel 5.17).

Om meer inzicht in de betrouwbaarheid van de vijf subvariabelen en de hoofdvariabele te krijgen werden de korrelaties berekend tussen de beide respondenten met betrekking tot de verschilscores op de betreffende onderwerpen.

Men kan uit tabel 5.15 konkluderen dat de beide respondenten het wel signifikant met elkaar eens waren wat betreft de invloedsverschillen tussen de drie hiërarchische lagen, maar dat de verbanden niet erg sterk genoemd kunnen worden.

Tabel 5.15 Korrelaties tusan de bedrijfsleiders en de personeelschefis met betrekking tot de loetreffende verschilgcores

\begin{tabular}{|l|c|}
\hline verschilscores met betrekking tot & $r=$ \\
\hline 1 werktempo & .24 \\
2 werkmethoden & .36 \\
3 vernieuwen gereedschap & .28 \\
4 bewordering & .22 \\
5 vrije diag krijgen & .25 \\
som wan alle vijf versch 1 lscores & .23 \\
\hline
\end{tabular}


Tabel 5. I6 De gendddelde scores van beide respondenten op de viff onderwerpen van variabele 32 en de resultaten van de toetsing van de varschillen tussen de bedrijuen en tussen de respondenten

\begin{tabular}{|c|c|c|c|c|}
\hline $\begin{array}{l}\text { verschilscores } \\
\text { met betrekking tot }\end{array}$ & $\begin{array}{l}\text { gemididelde } \\
\text { score van de } \\
\text { bedrijfs- } \\
\text { Leiders }\end{array}$ & $\begin{array}{l}\text { gemiddelde } \\
\text { score van de } \\
\text { personeels- } \\
\text { chefs }\end{array}$ & $\begin{array}{l}\text { signifikantie } \\
\text { van de ver- } \\
\text { schillen tussen } \\
\text { de bedri.jven }\end{array}$ & $\begin{array}{l}\text { signifikentie } \\
\text { van de ver- } \\
\text { schillen tussen } \\
\text { de respondenten }\end{array}$ \\
\hline 1 werktempo & 3.31 & 3.66 & .011 & .16 \\
\hline 2 werkmethoden & 4. 1.3 & 4.44 & .0005 & .12 \\
\hline $\begin{array}{l}3 \text { vernieuwen gereed- } \\
\text { schap }\end{array}$ & 3.71 & 4.20 & .005 & .02 \\
\hline 4 bevordering & 5.60 & 5.52 & .02 & .69 \\
\hline S wrije dag krijgen & 3.32 & 3.71 & .01 & .12 \\
\hline $\begin{array}{l}\text { som van alle vijf } \\
\text { verschil } 1 \text { scores }\end{array}$ & 20.06 & 21.52 & .02 & .04 \\
\hline
\end{tabular}

Tenslotte werd ook hier weer een aantal tweevoudige variantieanalyses uitgevoerd. Hierbij werd nagegaan of de verschilscores signifikant verschilden tussen de bedrijven en/of tussen de twee respondenten (tabel 5.16).

Allereerst ziet men wit de tabel dat de personeelschefs ook hier 'kritischer' oordeelden ten aanzien van de invloedsverschillen in de produktie dan de bedrijfsleiders; alleen blj het onderwerp bevordering is dat niet het geval. Voorts valt uit de tabel te konkluderen dat er tussen de 85 bedrijven op alle invloedsverschilscores signifikante verschillen bestonden. Het sterkst deed zich dit voor bij het onderwerp werkmethoden in de produktie. Uit de meest rechtse kolom valt of te lezen dat beide respondenten ten

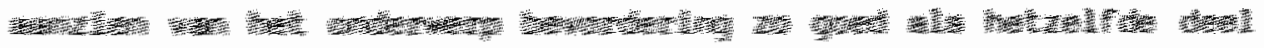

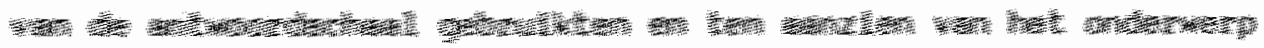

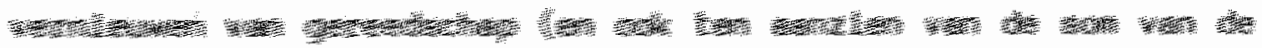

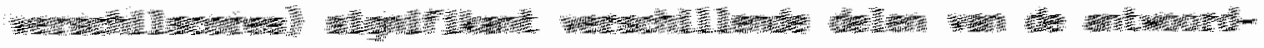

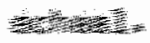

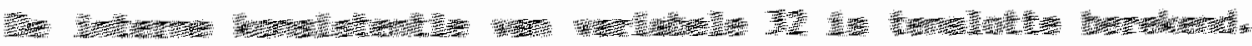

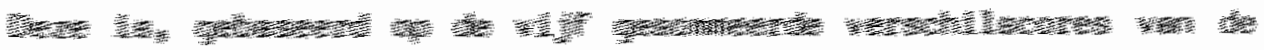

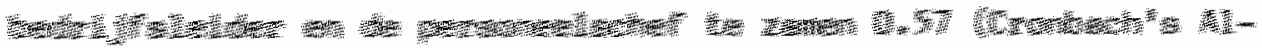

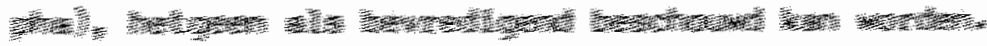

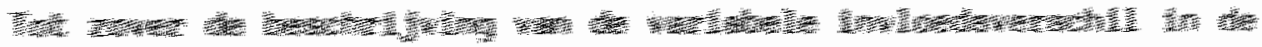

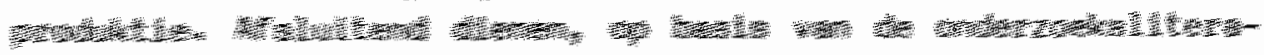

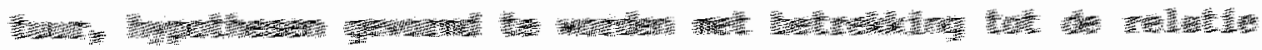


met het verzuim. Invloed ult kunnen defenen op beslissingen fook aan te dulden als participatie in beslissingen of decentralisatie van beslissingrame) is in een groot aantal boeken en artikelen in relatie met verzuim gebracht.

In concreto gat het hier am de publiketies van Weiss (1957), Lawler en Hackman (1969), Patchen (1970), Hackman en Lawler (1971), Powell en Schlacter (1971), Fried et al. (1972), Bragg en Andrews (1973), 0'Mulrcheartaigh (1975), Birchall en wild (1976), Singhal (1976), Cummings en Criggs (1976/77), Nicholson et al. (1977b), Vredenburgh en Alutto (1977), Ris (1978), Rousseau (1978), Smith (1978), Van Dijkhuizen (1980), Ekkers et al., (1980), Rhodes en Steers (1981). Tannenbaum en Cooke (1979) rapporteren in hun review van studies met de Control-graph geen onderzoek warin verzuim opgenomen is.

In genoemde negentien bronnen worden zeer veel negatieve, iets minder niet-signifikante en bijna geen positieve verbanden aangetroffen tussen de mate warin de werknemer invloed op beslissingen kan uitoefenen en zijn verzuimfrekwentie en/of het verzuimpercentage. Het $1 \mathrm{ijkt}$ darrom verantwoord om te veronderstellen dat in dit onderzoek grote invloedsverschillen tussen de leiding en de uitvoerenden in de produktie samen zullen gaan met een relatief hoge verzuimfrekwentie. Men mag ervan uitgaan dat grote invloedsverschillen zowel via geringe sociale als instrumentele binding van de werknemer aan de werksituatie tot uiting komen in een relatief hoge verzuimf rekwentie.

Tannenbaum (1968) gebruikte bij zijn onderzoek met de Controlgraph ook nog de 'total amount of control" (de totale invloed van wlle lagen te zamen) als index. Deze index is voor deze studie eveneens berekend met bovenvermelde vijf beslissingsonderwerpen, maar zal niet gebruikt warden, omdat de index wel verschilde tussen de respondenten $(p=.0006)$, maar niet tussen de bedrijven ( $p$ $=.15)$. Deze som-invloedscore vertoonde ook géén relaties met de verzuirmaten.

Ter afsluiting van deze paragraaf over de dertien toegevoegde variabelen - die in de vervolganalyse in hoofdstuk 7 gebruikt zullen worden - enige evaluatieve opmerkingen over hun gebruikswaarde, in casu hun betroumbaarheid en spreiding.

In het algemeen kan men konkluderen dat deze voldoende is. De 
vijf éen-item variabelen (groepsgrootte, grootte personeelsafdeling, werkloosheidspercentage rayon, snelheid verzuimkontrole en percentage buitenlandse werknemers) zijn gebaseerd op feitelijke dokumentatiegegevens (zie Bijlage II). De betrouwbarheild daarvan leek niet te wensen over te laten.

De drie twee-item variabelen (onrust in het produktieproces, vrijheid taakuitvoering en personeelsbegeleiding/-zorg) laten korrelaties zien tussen de betreffende twee subvariabelen van rond de .40, hetgeen als voldoende beschouwd mag worden. Bij de variabelen met drie of meer subvariabelen zijn betrouwbaarheidskoëfficiëntem berekend. Alleen Cronbach's Alpha bij de variabele instrumenteel leiderschap was aan de lage kant (.39);

Tabel 5.17 Gemiddelde en spreiding van de dertien toegevoegde wariabelen

\begin{tabular}{|c|c|c|c|c|}
\hline varíabelen & $\begin{array}{l}\text { theoret ische } \\
\text { variatie- }\end{array}$ & $\begin{array}{l}\text { emplicische } \\
\text { variatie- }\end{array}$ & $\begin{array}{l}\text { gemid- } \\
\text { delde }\end{array}$ & $\begin{array}{l}\text { Standaard- } \\
\text { dewitie }\end{array}$ \\
\hline $\begin{array}{l}20 \text { onrust in het praduktie- } \\
\text { praces (nieume versie) }\end{array}$ & $2-7$ & $2-7$ & 4.5 & 1.4 \\
\hline $\begin{array}{l}21 \text { vrijheid in de taakuit- } \\
\text { voering in de produktie }\end{array}$ & $2-8$ & $2-8$ & 5.4 & 1.4 \\
\hline $\begin{array}{l}22 \text { grootte van de groepen in } \\
\text { de produktie (span of } \\
\text { control baas) }\end{array}$ & $0-?$ & $4-39$ & 13.4 & 6.7 \\
\hline $\begin{array}{l}23 \text { relatieve grootte perso- } \\
\text { neelsardeling }\end{array}$ & $0-1000$ & $3-26$ & 9.6 & 3.9 \\
\hline $\begin{array}{l}2.4 \text { tijd besteed aan perso- } \\
\text { neelsbegeleiding en -zorg }\end{array}$ & $0-100 \%$ & $5-80 \%$ & $25.1 \%$ & $13.2 \%$ \\
\hline$---\cdots-----\cdots$ & $----\cdots$ & ---- & --- & ----- \\
\hline $\begin{array}{l}25 \text { slechte financieel-ekono- } \\
\text { milsche positie bedrijf }\end{array}$ & $3-10$ & $3-10$ & 5.1 & 2.2 \\
\hline $\begin{array}{l}26 \text { werkloosheidspercentige } \\
\text { van het rayon wasin het } \\
\text { bedriff ligt }\end{array}$ & $0-100 \%$ & $1 \cdot 1-12 \cdot 3$ & $4.4 \%$ & $2+28$ \\
\hline $\begin{array}{l}27 \text { snelheid van de verzulin- } \\
\text { kont role }\end{array}$ & $1-3$ & $1-3$ & 1.8 & 0.9 \\
\hline $\begin{array}{l}28 \text { aantal kontakten over } \\
\text { iekte werknemers }\end{array}$ & $3-9$ & $4-9$ & 6.7 & 1.3 \\
\hline $\begin{array}{l}29 \text { percentage buitenlandse } \\
\text { produkt iewerknemers }\end{array}$ & D-100恕 & $0-58 \%$ & $17.6 \mathrm{~g}$ & $13.8 \%$ \\
\hline 30 sociaal leiderschap & $6-1 B$ & $10-18$ & 14.5 & 1.9 \\
\hline 31 instrumenter leiderschap & $6-18$ & $10-18$ & $14 \cdot 3$ & 1.7 \\
\hline $\begin{array}{l}32 \text { inwloedswerschil tussen } \\
\text { leiding en uit toerenden } \\
\text { in de produkt ie }\end{array}$ & $(-30)-(90)$ & $26-63$ & 41.6 & 8.2 \\
\hline
\end{tabular}

N.B. B1jlage I geeft het gemiddelde en de spreiding van de subvariabelen wan de hier vermelde variabelen 
bij de variabelen sociaal leiderschap, invloedsverschil en financieel-ekonomische positie zijn deze koẻfficiënten minimaal . 53 . Voorts laten tweevoudige variantie-analyses bij de variabelen social leiderschap, instrumenteel leiderschap en invloedsverschil zien dat de bruikbaarheid wan deze drie instrumenten goed te noemen is.

Tenslotte kan uit de gegevens van tabel 5.17 (zie vorige pagina) en Bijlage I gekonkludeerd worden dat geen van de dertien toegevoegde variabelen onvoldoende spreidt over de 85 bedrijven. Kortom, er is geen reden om een van de dertien toegevoegde variabelen uit te sluiten vanwege gebrekkige betrouwbarrheid of spreiding.

\subsection{De drie verzuimmaten}

Het te verklaren begrip in dit onderzoek is het gemiddelde ziekteverzuim van het mannelijk produktiepersoneel.

$B i j$ de 85 in het onderzoek opgenomen bedrijven werkte gemiddeld 70 procent van het totale personeelsbestand in de produktiesektor, terwijl daarvan ongeveer 88 procent van het mannelijk geslacht was. Deze gegevens maken iets duidelijk van de relatieve omvang van de kategorie personeel (mannelijk produktiepersoneel) warop de verzuimcijfers in dit onderzoek berusten.

De inperking tot het mannelijk produktiepersoneel werd door Philipsen beargumenteerd door erop te wijzen dat in een onderzoek waarin organisatiekenmerken centraal staan, de werking van makrosociologische kategorieën - als produktie- of administratief personeel of mannelijk of vrouwelijk personeel - zoveel mogelijk uitgesloten dient te worden.

Bovendien, zo zou men hieraan toe kunnen voegen, hebben vele verklarende variabelen betrekking op aspekten van het produktieproces (technologie, werkomstandigheden, onrust, vrijheid, organisatiestruktuur, etcetera). Men zou hebben kunnen proberen deze variabelen te enten op de totale organisatie, maar dan zouden er totale bedrijfsscores zijn ontstaan die gebaseerd zouden zijn geweest op zeer uiteenlopende organisatie-aktiviteiten, als produktie, verkoop, inkoop, financiële administratie, etcetera. Zo'n totale bedrijfsscore zou dan ook tot grote interpretatieproblemen aanlelding hebben gegeven. Kortom, ook om dit soort interpretatieproblemen te vermijden, is inperking van de onderzoekspopula- 
tie en het verzuim tot de produktiesektor van de bedrijven aanbevelenswaerdig.

De drie verzuimmaten die in het onderzoek gebruikt zullen worden zijn dezelfde als Philipsen hanteerde:

- het verzuimpercentage, dit is het gemiddelde aantal verzuimde dagen per persoon per $100 \mathrm{kalenderdagen;}$

- de verzuimfrekwentie, dit is het gemiddelde aantal verzuimmeldingen per persoon per jaar;

- de gemiddelde duur per verzuimgeval (in kalenderdagen). Alle drie verzuimmaten zijn uiteraard bedrijfsgemiddelden en hebben betrekking op een periode van één jaar.

Een par opmerkingen verder nog ter verduidelijking. Ten eerste werd een verzuimgeval gedefinieerd als ieder geval van afwezigheid wegens arbeidsongeschiktheid, dat valt in de termen van de Ziektewet (en als zodanig aan het NIPC/TNO wordt gemeld). Dus gevallen van afwezigheid in verband met kursussen, ondernemingsraadaktiviteiten, vakantie, militaire dienst, etcetera vallen buiten de definitie. De bedrijven hanteren dus sterk eenduidige criteria, hetgeen van belang is voor de betrouwbaarheid.

Ten tweede dient erop gewezen te worden dat het verzuimpercentage van een bedrijf het produkt is van de twee andere verzuimmaten. Bij bedrijfsgemiddelden geldt namelijk dat het verzuimpercentage gelijk is an de verzuimfrekwentie $x$ de gemiddelde duur per verzuimgeval ( $x$ 100), gedeeld door de waarnemingsperiode.

Als dus de gemiddelde frekwentie in een bedrijf 1.5 gevallen per persoon per jaar is en de gemiddelde duur per geval is in dat jaar 19.5 kalenderdagen, dan is het verzuimpercentage $1.5 \times 19.5$ $(x$ 100) : $365=8.0$ procent. Dverigens is het meestal zo dat van een bedrijfspopulatie het aantal verzuimde dagen (verzuimpercentage) over een bepaalde periode bekend is alsmede het aantal verzuimgevallen (per werknemer). Hieruit ken dan een schatting gemaakt worden van de gemiddelde verzuimduur per geval door het aantal verzuimde dagen te delen door het aantal verzuimgevallen. Het belangrijkste is dat hier gestipuleerd wordt dat er een bepaalde verhouding is tussen de drie in het onderzoek te gebruiken verzuimmaten. Het verzuimpercentage is dus, zoals Philipsen (1969, p. 172) het uitdrukte, een afgeleide mat en bevat naast de verzuimfrekwentie en de gemiddelde duur per geval geen verdere informatie. Het verzuimpercentage zou derhalve als afhankelijke 
varlabele verder uit het onderzoek weggelaten kunnen worden. Daartegen zijn echter twee bezwaren in te brengen: (1) een verklarende variabele kan zwak - niet-signifikant - met zowel de frekwentie als de gemiddelde duur samenhangen en daardoor sterker en wèl signifikant met het produkt van deze beide maten, het verzuimpercentage; in een dergelijk geval kan het verzuimpercentage, als produkt-maat, zijn diensten bewijzen (Philipsen, 1969, p. 172); (2) het verzuimpercentage is verder van praktisch belang; bijna alle bedrijven werken ermee in de praktijk omdat dit percentage het beste de kosten ('de verloren dagen') indiceert die met het verzuim gepaard gean. Dok dit tweede punt pleit tegen weglating van het verzuimpercentage.

Alvorens in te gaan op de stabiliteit van de drie verzuimmaten in de tijd en op hun onderlinge samenhang, valgen hier nu eerst ( $p$. 145) het gemiddelde en de spreiding van de drie gebruikte verzuimmaten in 1964/65 en in 1980/81.

Uit tabel 5.18 ziet men dat het verzuimpercentage van de onderzochte bedrijven in $1964 / 65$ gemiddeld op 7.1 percent lag, terwijl het in 1980/81 op 11.7 percent was gekomen. Opvallend is dat in de tijd tussen beide perioden de verzuimfrekwentie veel sterker gestegen is (van 1.37 naar 2.19) dan de gemiddelde duur per geval (van 18.9 naar 20.2 dagen). Landelijk valt bij de mannelijke werknemers eenzelfde - hoewel minder uitgesproken - tendens in de cijfers waar te nemen.

Belangrijk is nog te vermelden dat de verzuimcijfers betrekking hebben op het jaar 1980, terwijl de rest van het onderzoeksmateriaal (de informatie over de verklarende variabelen) in 1981 verzameld werd. De reden hiervan was dat de verzuimgegevens over 1981 ntet van alle 85 bedrijuen beschikbaar waren.

Men zou hier nu tegenin kunnen brengen dat de koppeling van gegevens uit twee verschillende jaren onjuist is. Echter, verzuimmaten op het organisatienivo zijn zeer stabiel, zoals Philipsen (1969, p. 178-182) reeds aantoonde voor 54 van zijn onderzochte bedrijuen en voor 72 grotere bedrijven. Dat wil zeggen dat een bedrijf, dat in een bepaald jaar een zeer hoog verzuimpercentage, een hoge frekwentie of lange gemiddelde verzuimduur heeft, dat in het volgend jaar met vrij grote zekerheid ook heeft.

Om na te gaen of deze bevindingen van Philipsen in latere jaren ook juist zijn, zijn dit soort stabiliteitsanalyses gepleegd voor 


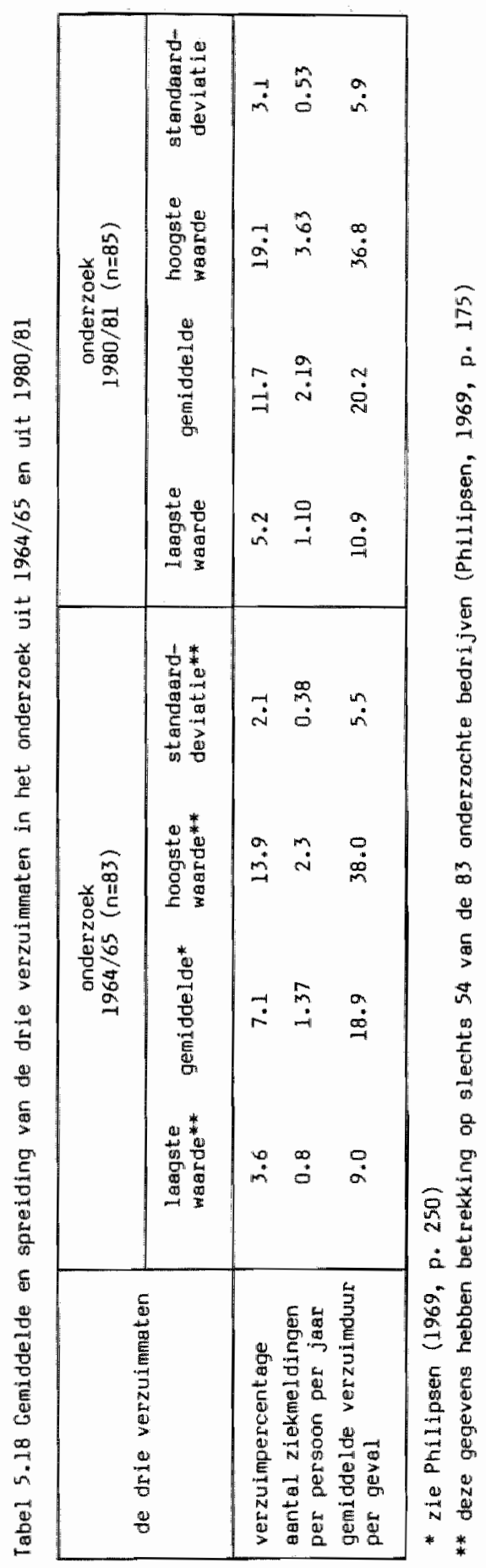


de vier jaren 1974 tot en met 1977 op basis van verzuimgegevens van 237 organisaties (voor het merendeel produktiebedrijven, maar ook enkele tientallen gemeente- en bankinstellingen) die gedurende alle vier jaren meededen aan de NIPG-statistiek. De verzuimgegevens van deze 237 organisaties zijn berekend voor acht perioden van een halfjaar. Vervolgens zijn voor elk van de drie verzuimmaten, de korrelaties berekend tussen de acht halve jaren; dus tussen het eerste en tweede halfjaar, tussen het eerste en derde halfjear, etcetera, tot en met tussen het zevende en achtste half jaar.

Zo waren er dus zeven korrelaties die betrekking hadden op perioden die een halfjaar in de tijd verschilden (dus op elkaar volgend), zes korrelaties die betrekking hadden op perioden die een jaar in de tijd verschilden (dus met een halfjear ertussen), etcetera etcetera. De korrelaties die betrekking hadden op perioden met eenzelfde tijdsverschil werden vervolgens gemiddeld.

Tabel 5.19 Gemiddelde korrelaties tussen helfjarlijkse perioden $(1974-1977)$ met betrekking tot de drie verzuimmaten, gebaseerd op gegevens van 237 organisaties

\begin{tabular}{|c|c|c|c|c|}
\hline $\begin{array}{l}\text { verschillen tussen de } \\
\text { half jaarli jkse perioden }\end{array}$ & $\begin{array}{l}\text { eantal } \\
\text { korrelaties } \\
\text { dat gemid- } \\
\text { deld is }\end{array}$ & $\begin{array}{l}\text { verzuim- } \\
\text { percentage }\end{array}$ & frekwentie & $\begin{array}{l}\text { gemiddelde } \\
\text { duur per } \\
\text { geval }\end{array}$ \\
\hline helf jaar & 7 & .85 & .87 & .85 \\
\hline ến jaar & 6 & .77 & .81 & .76 \\
\hline anderhe if jaar & 5 & .73 & .77 & .72 \\
\hline twee jaar & 4 & .71 & .74 & .72 \\
\hline tweeënhalf jaar & 3 & .71 & .71 & .68 \\
\hline drie Jaar & 2 & .72 & .72 & .69 \\
\hline $\mathrm{dr}$ ieennalf jaar & 1 & .68 & .65 & .59 \\
\hline
\end{tabular}

Men zlet uit tabel 5.19 dat de drie verzuimmaten in de tijd ongeveer even stabiel zijn. Dok laat de tabel zien dat naarmate de tijd tussen de perioden langer wordt, de voorspelling van de hoogte van het verzuim uit een vorige periode onbetrouwbaarder wordt. De hoofdkonklusie uit de cijfers is, dat de positie van een organisatie ten opzichte van de andere organisaties met betrekking tot alle drie verzuimmaten in grote mate gelijk blijft in de tijd.

Voor dit onderzoek betekent het dat de verzuimcijfers van een be- 
drijf over 1980 zo goed als dezelfde informatie geven als de verzuimcijfers over 1981 of over $1980 / 81$. Gebruikmaking van verzulmcijfers over 1980 voor een onderzoek waarbij het materiaal voor de verklarende variabelen in 1981 plaatsvond is derhalve geen beZwaar.

Overigens zal om redaktionele redenen wel steeds gesproken worden van het onderzoek uit $1980 / 81$, dit ter onderscheiding van het onderzoek van Philipsen, warvan de materiaalverzameling in 1964/65 plaatsvond.

Tenslotte dient nog een laatste aspekt van de verzuimmaten voor het voetlicht gehaald te worden. Dit betreft de onderlinge verbanden tussen de drie verzuimmaten en de konsekwenties daarvan. In onderstaande tabel 5.20 wordt voor vijf verschillende kategorieën van bedrijven en instellingen uit verschillende perioden weergegeven wat het gevonden verband is tussen de drie verzuimmaten.

Tabeli 5.20 Korrelaties tussen de drie verzulmmeten woor vijf vergchillende kategarieën van organisaties uit verschillende periodes

\begin{tabular}{|c|c|c|c|}
\hline $\begin{array}{l}\text { kategorieën } \\
\text { organisaties }\end{array}$ & $\begin{array}{l}\text { verzuim- } \\
\text { percentage } \\
\times \text { frekwentie }\end{array}$ & $\begin{array}{l}\text { verzuilim- } \\
\text { percentage } \\
\text { * gemiddelde } \\
\text { duur per geval }\end{array}$ & $\begin{array}{c}\text { frekwentio } \\
x \text { gemiddelide } \\
\text { duur per geval }\end{array}$ \\
\hline $\begin{array}{l}n=54 \text { kleinere produkt ie- } \\
\text { bedr } 1 \text { jven }(1964 / 65) *\end{array}$ & .31 & .62 & -.49 \\
\hline $\begin{array}{l}n=72 \text { grotere produktie- } \\
\text { bedrijven }(1964 / 65)^{*}\end{array}$ & .23 & .51 & -.67 \\
\hline $\begin{array}{l}n=56 \text { sociale werkplat- } \\
\text { sen }(1972 / 73)\end{array}$ & .37 & .58 & -.41 \\
\hline $\begin{array}{l}n=237 \text { bedidiven en in- } \\
\text { stelingen }(1974 / 77)^{* * *}\end{array}$ & .36 & .69 & -.35 \\
\hline $\begin{array}{l}n=85 \text { produkt iebedrijven } \\
(1900 / 81)^{*}\end{array}$ & .39 & .59 & -.48 \\
\hline
\end{tabular}

* Philipsen (1969, p. 181, 185)

* Dijkstra (1977, p. 78, 82)

** het betreft hier de eerder beschreven 237 orgenisaties, die in de perlade 1974 . 1977 an de NIPG-statistiek meededen; de kormelaties zijn de gemiddelden over acht halwe jeren

*** het betreft hier de bedrijuen uit dit onderzoek

De tabel laat zien dat de patronen in de vijf verschillende kategorieën organisaties ongeveer identiek zijn. Het sterkste posi- 
tieve verband bestaat steeds tussen het verzuimpercentage en de gemiddelde duur per geval, terwijl de korrelaties tussen het verzuimpercentage en de frekwentie steeds lager zijn. Dit betekent dus dat het verzuimpercentage in sterkere mate door de gemiddelde duur per geval wordt bepaald dan door de frekwentie.

Voorts is duidelijk dat de relatie tussen de frekwentie en de gemiddelde dur per geval in alle vijf kategorieën organisaties sterk negatief is. Philipsen (1969, p. 182-184) heeft de logisch/rekentechnische en de empirische achtergrond van deze negatieve samenhang uitvoerig belicht. Hij trok hieruit de konklusie dat bij de berekening van de samenhang tussen een verklarende variabele en de verzuimfrekwentie de gemiddelde verzuimduur - door middel van partiële korrelatieberekening - konstant gehouden moet worden. Hetzelfde geldt voor de relaties met de gemiddelde verzuimduur, waarbij de frekwentie konstant gehouden moet worden. Deze konklusie wordt hier onderschreven en er zal bij de analyse van het materiaal rekening mee gehouden worden.

Wellicht ten overvloede zij hier nog bij vermeld dat als men verbanden berekent tussen de verklarende variabelen en de verzuimfrekwentiemaat onder konstant-houding van de verzuimduurmaat, men op de keper beschouwd naar bedrijven kijkt met gelijke gemiddelde duur, maar met verschillen in de frekwentie. En men vindt dan dus die verklarende variabelen, die alleen relevant zijn voor de frekwentie (schijnverbanden door inwerking van de duur zijn er als het ware uitgehaald).

Dezelfide redenering geldt uiteraard voor de duurmaat waarbij de frekwentiemaat konstant wordt gehouden. 


\subsection{De struktuur van dit hoofdstuk}

In hoofdstuk 3 werd uiteengezet dat een belangrijk deel van het empirisch onderzoek in deze studie de replikatie betreft van het onderzoek van Philipsen (1969), hetwelk hij in 1964/65 uitvoerde met negentien verklarende variabelen en drie verzuimmaten.

In dit hoofdstuk zal deze replikatie-analyse verslagen worden. Hierbij zullen ook dezelfde analysetechnieken gebruikt worden als degene die Philipsen gebruikte. Faktoranalyse en korrelatie-analyse zijn de belangrijkste.

In paragraaf 6.2 zullen de negentien verklarende variabelen onderling geanalyseerd worden. Het voornaamste doel is daarbij na te gaan in hoeverre er eenzelfde struktuur in ontdekt kan worden als in $1964 / 65$.

In paragraaf 6.3 zullen door middel van nulde-orde, partiële en multipele korrelaties de verbanden aangegeven worden tussen de negentien verklarende variabelen en de drie verzuimmaten. Ook hier zal het aksent weer liggen op de vraag of de konklusies uit het onderzoek van 1964/65 houdbaar zijn gebleven. In deze paragraaf zullen de verbanden tussen de verklarende en de te verklaren variabelen eveneens op kromlijnigheid getoetst worden.

Paragraaf 6.4 behelst een bespreking van de niet-bevestigde resultaten, terwijl in paragraaf 6.5 de door Philipsen opgestelde hypothesen getoetst worden tegen de achtergrond van de resultaten uit beide onderzoeken.

In paragraaf 6.6 wordt, op basis van de resultaten, de validiteit van de gebruikte negentien variabelen onder de loupe genomen. Tenslotte is paragraaf 6.7 een samenvatting van dit hoofdstuk.

Overigens zij er hier reeds op gewezen dat bij de analyses een laagste signifikantienivo van $p=.10$ aangehouden zal worden. Deze lage drempel kan verdedigd worden door erop te wijzen dat het hier on sociaal-wetenschappelijk onderzoek gaat, warbij het mogelijk gevolg van het relatief lage signifikantienivo, namelijk het ten onrechte konkluderen dat er een verband aanwezig is, minder onacceptabel is dan bij meer technisch-wetenschappelijk onderzoek warbij het hele onderzoeksdesign en de variabelen "har- 
der' kunnen zijn (vergelijk Plantenga, 1981). Dus, om niet te snel gestelde hypothesen te verwerpen, wordt de acceptatiedrempel relatief laag gehouden.

\subsection{De onderlinge samenhang van de negentien verkla- rende variabelen}

De korrelaties tussen de negentien verklarende variabelen worden in tabel 6.1 gepresenteerd. Als men de gegevens uit deze tabel vergelijkt met dezelfde gegevens uit het onderzoek van Philipsen, blijkt dat de interkorrelaties nogal wat lager uitvallen.

Philipsen vond bijvoorbeeld tien korrelaties met een warde $\geqslant .40$ (zie Bijlage III), terwijl er in tabel 6.1 maar twee van derge1ijke hoge korrelaties aangetroffen worden. De belangrijkste oorzaak van dit verschijnsel is waarschijnlijk gelegen in het feit dat het merendeel van de negentien variabelen in 1964/65 een grotere spreiding vertoonde over de warden dan in 1980/81. Men zie hiervoor de standaard-deviaties in tabel 5.9 (p. 104-105) wit het vorige hoofdstuk.

De 83 bedrijven van Philipsen waren dus meer gespreid of heterogener van samenstelling dan de 85 bedrijven in het 1980/81-onderzoek. Hoewel slechts naar de oorzaak gegist kan worden, is de grotere homogeniteit van de bedrijven in $1980 / 81$ een interessant verschijnsel. Mogelijk hebben de wetgeving ten aanzien van arbeidsomstandigheden en voorzieningen in bedrijven, intensiever kommunikatie en publikatie over arbeidssituaties alsmede vakbondsaktiviteiten een rol gespeeld in de 'homogeniserende" trend, die waarneembar is in de cijfers. Mogelijk ook zien we hier de effekten van wat Lammers (1983, p. 442-444) en anderen het proces van natuurlijke selektie of van eliminatie van 'ongeschikte' soorten organisaties hebben genoemd. Hierbij wordt ervan uitgegaan dat organisaties die slecht aengepast zijn aan hun omgeving en dergelijke op den duur failliet gaan of om andere redenen verdwiijnen. Uiteraard is ook mogelijk dat het hier om min of meer toevallige veranderingen in de steekproeven gaat of dat de variabelen in 1964/65 juist op heterogeniteit (grote variantie) geselekteerd zijn geweest.

De grotere homogeniteit van de bedrijven uit het onderzoek van $1980 / 81$ heeft ook nog andere effekten. De kans is hierdoor name- 


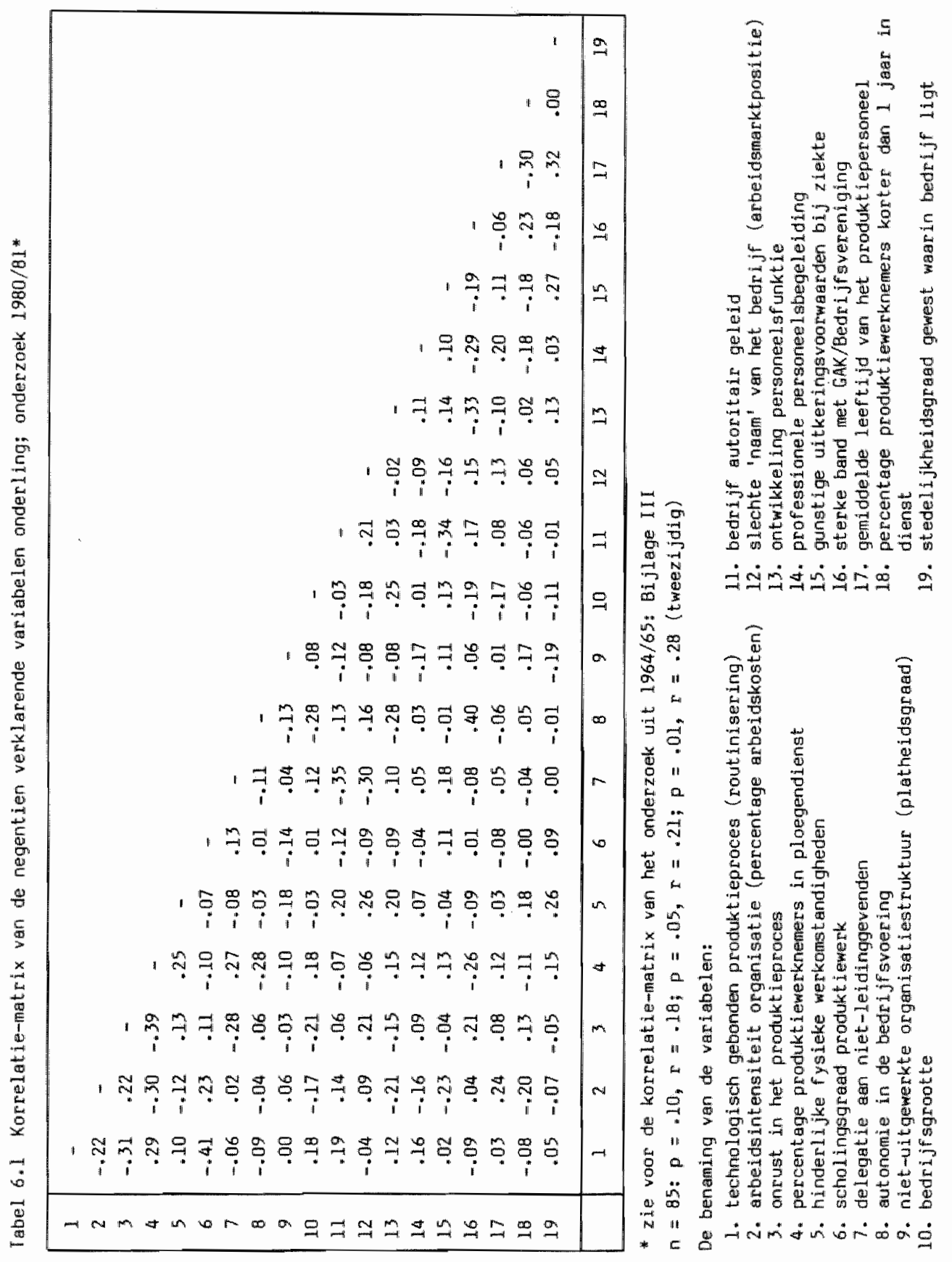


$11 j k$ groter dat de relaties met de verzuimmaten lager uitvallen. Gunstig daarbij is echter dat de spreiding in de drie verzuimmaten in 1980/81 groter is dan in 1964/65 (zie tabel 5.18, p. 145), zodat daarmee de kans op verlaging van de verbanden weer wat teniet gedaan zal worden.

Voorts werkt de relatief geringe spreiding in de negentien verklarende variabelen dóór in een faktoranalyse die gepleegd wordt op deze variabelen. Het percentage geëxtraheerde (of gebonden) variantie is namelijk - behalve van het aantal berekende faktoren - ook afhankelijk van de hoogte van de korrelaties in de te faktoranalyseren matrix.

Tabel 6.2 geeft de resultaten van de uitgevoerde faktoranalyse op de negentien verklarende variabelen na rotatie. Philipsen extraheerde met een gelijksoortige faktoranalyse (eveneens met vijf faktoren) 56.1 procent van de variantie in de negentien variabelen. Dat is heel wat meer dan het hier geëxtraheerde variantiepercentage van 34.2 .

Dan nu over near de inhoudelijke kant van de faktoranalyse. Positief is het feit dat de faktoranalyse tot op zekere hoogte eenzelfde beeld laat zien als in $1964 / 65$ (zie Bijlage IV). Vier van de vijf getrokken faktoren lijken op vier van de vijf faktoren uit 1964/65. De namen die Philipsen hun gaf zijn voor deze vier faktoren dan ook gehandhaafd.

Nog vermeld kan hierbij worden dat, op statistische gronden, de vijf faktoren-oplossing acceptabel is; bij vijf faktoren hoort namelijk een thèta-waarde van 1 , hetgeen indiceert dat er voldoende faktoren in de oplossing opgenomen zijn om de korrelatiematrix te "verklaren".

De eerste faktor, routinisering van het produktieproces, heeft precies dezelfde inhoud als faktor II uit 1964/65. In volgorde van hun lading $z i j n$ het de variabelen:

- technologisch gebonden produktieproces

$+.62$

- rustig produktieproces

$+.51$

- hoog percentage ongeschoolde arbeid

$+.48$

- veel ploegendienst

$+.45$

- kapitaalintensieve organisatie

$+.43$

De tweede gevonden faktor lijkt zeer sterk op faktor III van Philipsen en kan ook zo betiteld worden: wervingskracht van de organisatie. 


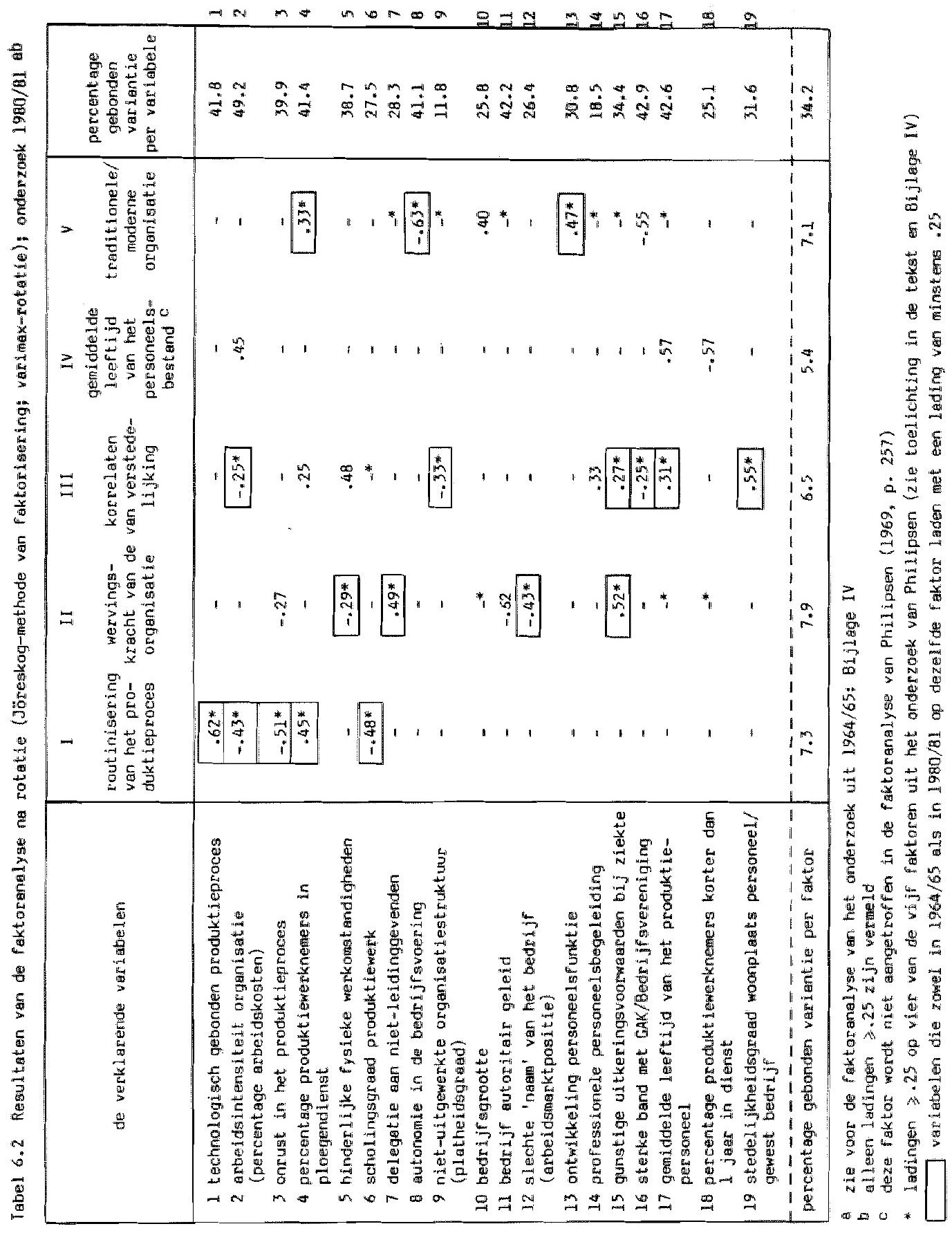


De variabelen die thans tot deze faktoren behoren, zijn in volgorde van hun lading:

- bedrijf demakratisch geleid

- gunstige uitkeringsvoorwaerden bij ziekte

- delegatie van bevoegdheden aan niet-leidinggevenden

- goede 'naam' van het bedrijf

- geen hinderlijke fysieke werkomstandigheden

- rustig produktieproces

Vier van deze variabelen laadden ook in 1964/65 op deze faktor. De variabele delegatie laadde er toen echter negatief op, terwijl hij thans in de - plausibeler - positieve richting wijst.

De derde gevonden faktor in deze faktoranalyse lijkt sterk op faktor $V$ van Philipsen, korrelaten van verstedelijking. De volgende variabelen behoren tot deze faktor:

- bedrijf ligt in stedelijk gebied

- hinderlijke fysieke arbeidsomstandigheden

$+.48$

- professionele personeelsbegeleiding

$+.33$

- uitgewerkte, relatief steile, organisatiestruktuur

- oud personeelsbestand

- gunstige uitkeringsvoorwaarden bij ziekte

$+.31$

- veel ploegendienst

$+.27$

$+.25$

- zwakke band met GAK/Bedrijfsvereniging (dus relatief vaak afdelingskas/eigenrisikodrager)

- kapitaalintensieve organisatie

Zoals tabel 6.2 laat zien, laadden zes van deze negen variabelen in 1964/65 ook relatief hoog op deze faktor.

De vierde faktor die in deze faktoranalyse gevonden wordt is geheel nieuw. $\mathrm{HIj}_{\mathrm{j}}$ is gemiddelde leeftijd van het personeelsbestand genoend en bestaat uit de volgende drie variabelen:

- weinig korte diensttijiden

- oud personeelsbestand $+.57$

- arbeidsintensieve organisatie $+.45$

Deze faktor kwam bij Philipsen niet voor. Met betrekking tot de vijfde en laatste gevonden faktor is dat weer wel het geval. Deze lijkt namelijk op de eerste door Philipsen gevonden faktor. De overeenkomst is echter minder sterk dan dat bij de eerste drie faktoren het geval was. Evenals bij Philipsen is deze faktor traditionele/moderne organisatie genoemd. 
In volgorde van belang vallen nu de volgende variabelen eronder:

- geen autonomie in de bedrijfsvoering (dus relatief valk onderdeel van een concern)

- zwakke band met GAK/Bedrijfsvereniging (dus relatief vaak afdelingskas/eigenrisikodrager)

- ontwikkelde personeelsfunktie

- grote bedrijfsomvang

- veel ploegendienst

Deze faktor toont aan dat bedrijfsonderdelen van een groter concern relatief vaak een ontwikkelde personeelsafdeling hebben, die zich intensief bemoeit met de administratie en behandeling van de ziektewetkontrole. Tevens zijn dit verhoudingsgewijs grote bedrijuen met ploegendienst.

Twee zaken vallen bij de samenstelling van deze vijfde faktor, in vergelijking tot dezelfde van Philipsen, op. Ten eerste ontbreken de twee variabelen die de vertikale relaties indiceren (delegatie en demokratische/autoritaire leiding) alsmede de organisatiestrukturele variabele over de steilheid of platheid van de organisatie. Dat ook de variabele professionele personeelsbegeleiding ontbreekt kan te maken hebben met het feit dat deze variabele thans (door spreidingsproblemen in de subvariabelen) veel eerder selektie-strengheid meet dan professionele personeelsbegeleiding (zie p. 95).

Ten tweede is opvallend dat de variabele bedrijfsgrootte, die te zamen met ontwikkelde personeelsfunktie bij Philipsen de nog niet genoemde en overblijvende faktor vormde, hier in de faktor moderne/traditionele organisatie opgenomen is.

Tot zover de weergave van de vijf in de faktoranalyse gevonden faktoren. Bespreking van dit vijftal tegen de achtergrond van bestaande organisatie-saciologische literatuur, zal hier niet plastsvinden. Dit wordt uitgesteld tot het volgende hoofdstuk, waarin elf van de hier gehanteerde variabelen, te zamen met dertien nieuwe, opnieuw aan een faktoranalyse onderworpen zullen worden. Dok zullen hier geen kausaliteitsketens ontwikkeld worden, zoals Philipsen dat deed met zijn vijf faktoren en de daartoe behorende variabelen. Dok dit wordt uitgesteld tot de analyse in hoofdstuk 7 . Daar zal een aantal voor het verzuim belangrijke faktoren met behulp van de op kausaliteit gerichte statistische techniek LISREL geanelyseerd worden. 
6.3 De relaties van de negentien verklarende variabelen met. het verzuim

Ter bepaling van de relaties tussen de negentien verklarende varlabelen en de drie verzuimmaten zijn nulde-orde korrelaties, partiële korrelaties en multipele korrelaties berekend. Met de toepassing van deze statistische analysetechnieken wordt opnieuw de anpak van Philipsen (1969) gevolgd, waardoor optimale verge$11 j k i n g$ van beide onderzoeken mogelijk is.

Omdat in dit hoofdstuk het aksent ligt op de vergelijking van de resultaten uit $1964 / 65$ met die uit $1980 / 81$, zullen de gevonden resultaten niet op zich maar voornamelijk vergelijkenderwijs besproken worden.

Tabel 6.4 geeft de nulde-orde korrelaties uit het onderzoek van $1964 / 65$ en dat van 1980/81. Daaruit kan gekonkludeerd worden in hoeverre de resultaten van beide onderzoeken overeenkomen of verschillen. Bevestiging of ontkenning van eerdere resultaten kan gebaseerd $z i j n$ op het feit dat in beide onderzoeken de resultaten in dezelfde richting signifikant $(p<.10)$ zijn, mar ook dat de resultaten in beide onderzoeken niet-signifikant $(p \geqslant .10)$ zijn.

Tabel 6.3 Vergelijking van de nulde-orde korrelaties uit beide onderzoeken

\begin{tabular}{|c|c|c|c|}
\hline resultaten & $\begin{array}{l}\text { verzuim- } \\
\text { frekwentie }\end{array}$ & $\begin{array}{l}\text { gemiddelde } \\
\text { duur per geval }\end{array}$ & $\begin{array}{l}\text { verzuin- } \\
\text { percent } 9 \text { ge }\end{array}$ \\
\hline $\begin{array}{l}\text { resultaten in beide onderzoeken } \\
\text { signifikent of in beide niet- } \\
\text { silgniflikant }\end{array}$ & $7 \quad(37 \%)$ & $10 \quad(53 \%)$ & $11 \quad(58 \%)$ \\
\hline $\begin{array}{l}\text { regultaten in beide onderzoeken } \\
\text { versohillend }\end{array}$ & $\begin{array}{l}----- \\
12\left(63 y^{\prime}\right)\end{array}$ & $\begin{array}{c}------1 \\
9 \quad(47 \%)\end{array}$ & $8 \quad(42 \%)$ \\
\hline totaal & $19(100 \%)$ & $19 \quad(100 \%)$ & 19 (100\%) \\
\hline
\end{tabular}

Uit tabel 6.3 - die gebaseerd is op de gegevens van tabel 6.4 valt af te lezen dat indien dit criterium wordt toegepast, bij de frekwentie zeven van de negentien relaties ( $=37$ procent) bevestigd worden, bij de gemiddelde duur per geval tien van de negentien ( $=53$ procent) en bij het verzuimpercentage elf van de negentien $(=58$ procent $)$. De resultaten met betrekking tot de ver- 


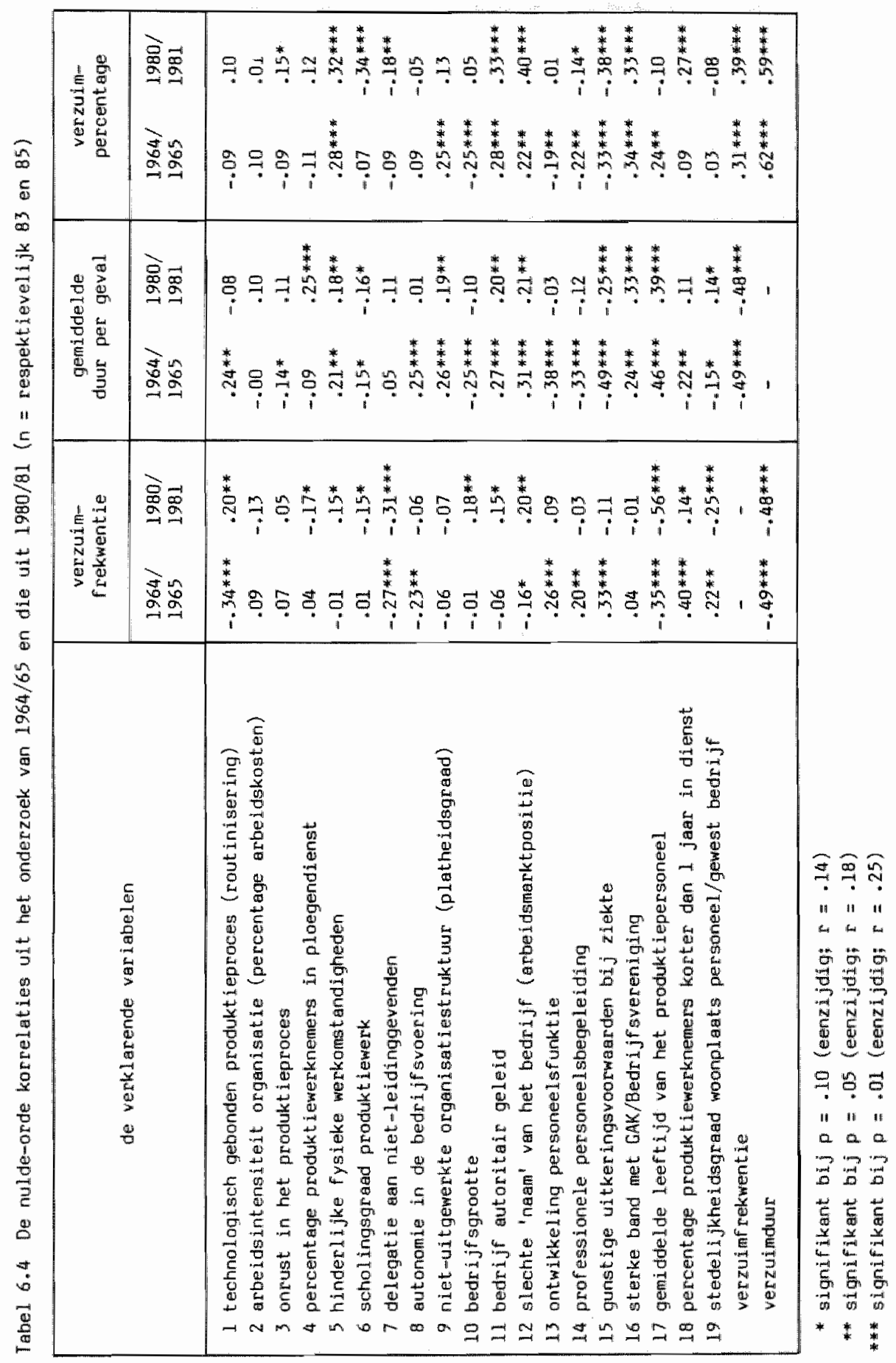


zuimduur en het verzuimpercentage lijken dus stabieler in de tijd den die met betrekking tot de frekwentie. Van alle 57 relaties wordt op deze manier 49 procent bevestigd.

Overigens kan bevestiging of antkenning van eerdere onderzaeksresultaten ook nog op een andere manier benaderd worden, namelijk door na te gaan of er signifikante verschillen zijn tussen de paren korrelaties. Dat criterium is wat minder rigide dan het in tabel 6.3 toegepaste criterium en $z a l$ bij de definitieve vergelijking van de (partiële) korrelaties gebruikt worden.

De nulde-orde relaties $z i j n$ ook op eventuele kromlijnigheid getoetst. Zoals bekend, geeft een korrelatie-koëfficiënt van het verband tussen twee variabelen alleen het lineaire aspekt weer. Als het verband tussen twee variabelen kromlijnig is, drukt de korrelatie-koëfficiënt als het ware de best passende rechte lijn uit die bij die kromme pest. Additionele toetsing op kromlijnigheid is dus niet overbodig. Inhoudelijk is het ook van belang omdat ten aanzien van variabele 1 (routinisering) door Philipsen (1969, p. 151) een kromlijnig verband met de verzuimfrekwentie verondersteld werd. Nagegaan moet dus worden of die veronderstelling juist is; in $1964 / 65$ bleek de bedoelde relatie overigens rechtlijnig (Philipsen, 1969, p. 194).

Welnu, van alle $57(3 \times 19)$ mogelijke verbanden is nagegaen of deze recht-den wel kromlijnig zijn. Dit geschiedde door middel van polynomiale regressie-analyse (Pedhazur, 1982, p. 405-406). Hierbij wordt naast de verklarende variabele zelf eerst het kwadraat en vervolgens eventueel ook nog de derde macht van de verklarende variabele in de regressie-vergelijking ingevoerd en bij elke stap wordt nagegaan of deze tweede- en derdegraadstermen nog sigmifikante toevoegingen opleveren aan de verklaring van de afhankelijke variabele.

Op deze wijze werd allereerst vastgesteld dat de relatie tussen het type produktieproces (routinisering) en de verzuimfrekwentie inderdaed signifikant kromlijnig is, namelijk een U-relatie (zie figuur 6.1). De nulde-orde relatie, die het rechtijinig verband weergeeft, was hier $r=.20$, terwijl de multipele korrelatie van de rechtlijnige en de kromlijnige komponent samen $R=.29$ is. Om figuur 6.1 (en ook de figuren 6.2 en 6.3) goed te begrijpen dient men zich te realiseren dat zowel de rechtlijnige als de kromlijnige weergaven van het verband 'geoptimaliseerd' zijn; dus 
Fiquur 6.1 De rechtiljnige en kromlijnige vorm van de rellatie produktiepracestype (verlabele 1) - werzulnf rekwentie

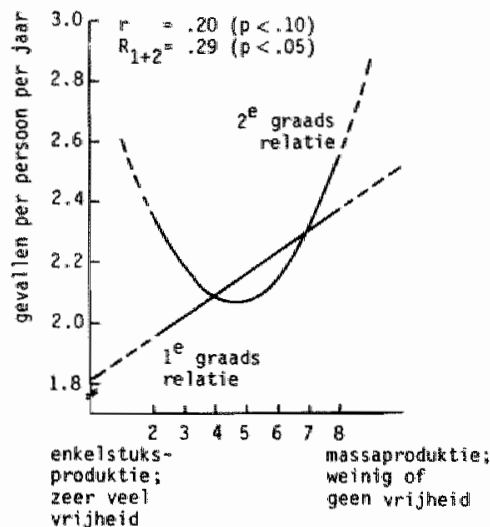

Figuur 6.2 De recht 11 jnlge en kromilj nige vorm van de relatie achollngagraad (vartabele 6)

- verzuimpercentege

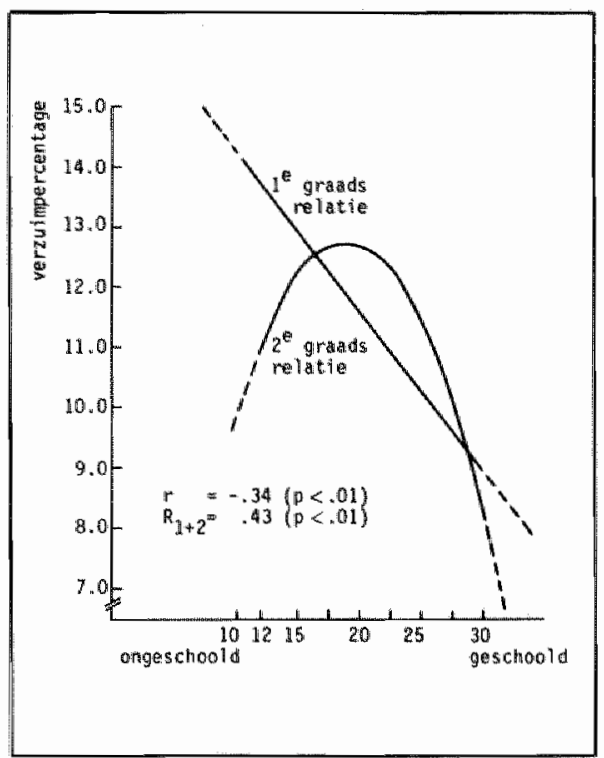

Figuur 6.3 De rechtlijnige en kromlijnige varm van de relatile uitkeringeworwarden (variabele 15) - gemiddelde duur per werzulingeval

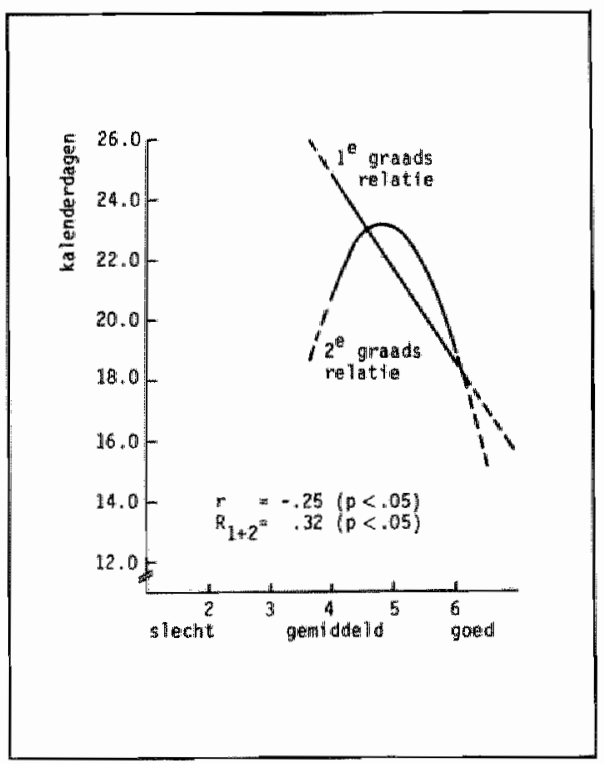


de werkelijke "puntenwolk" die het verband tussen beide variabelen weergeeft is veel grilliger dan de weergegeven "gestroomlijnde' lineaire en curvilineaire verbanden.

Dok de relatie scholingsgraad van het werk - verzuimpercentage is kromlijnig, namelijk een omgekeerde U-relatie (zie figuur 6.2). De nulde-orde korrelatie was hier $r=-.34$ en de multipele korreLatie van beide komponenten te zamen met het verzuimpercentage is $R=.43$. In grote lijnen gaat dus niet alleen hooggeschoold, maar ook laaggeschoold produktiewerk samen met een lager verzuimpercentage dan gemiddeld geschoold werk.

Tenslotte is er ook een kromlijnige relatie warneembar tussen uitkeringsvoorwarden bij ziekte en de gemiddelde verzuimduur per geval, ook een omgekeerde U-rellatie (zie figuur 6.3). De nuldeorde korrelatie is hier $r=-.25$, terwijl de multipele korrelatie van beide komponenten te zamen met de verzuimduur $R=.32$ is. Overigens dient men geen overdreven waarde te hechten aan dit laatste kromlijnige verband omdat de variabele uitkeringsvaorwaarden een geringe spreiding kent; de empirische variatiebreedte loopt slechts van 4 tot en met 6 , met respektievelijk 5, 24 en 56 bedrijuen.

Bij de verderop weer te geven partiële korrelaties zijn de kromlijnige aspekten van de drie bedoelde variabelen overigens niet in de regressie-analyse opgenomen. Dit zou trouwens ook het replikatiekarakter van het onderzoek een andere dimensie hebben gegeven.

Tot zover enige globale konklusies ten aanzien van de nulde-orde korrelaties. Meer gedetaileerde konklusies komen nu aan de orde bij de partiële korrelaties. Op dit punt is het goed er nog even aan te herinneren dat de verklarende variabelen onderling geen extreem hoge verbanden vertoonden (slechts twee korrelaties kwamen boven $r=.40$ ). Dit betekent dat er bij de regressie-analyses geen gevar is voor zogenaamde 'multicollineariteit'-effekten. Hiermee wordt bedoeld dat bij zeer hoge interkorrelaties tussen verklarende variabelen onbetrouwbare partiële koëfficiënten kunnen ontstaan met een afhankelijke variabele (Gordon, 1968).

Verder dient er op dit punt nog op gewezen te worden dat in de partiële korrelatierekening bij de gemiddelde verzuimduur per geval de frekwentie konstant is gehouden en bij de frekwentie de gemiddelde duur per geval. Bij de frekwentie en de duur werden 


\begin{tabular}{|c|c|c|c|}
\hline 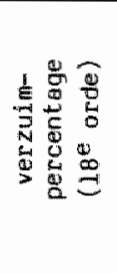 & 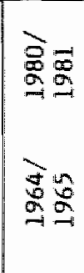 & 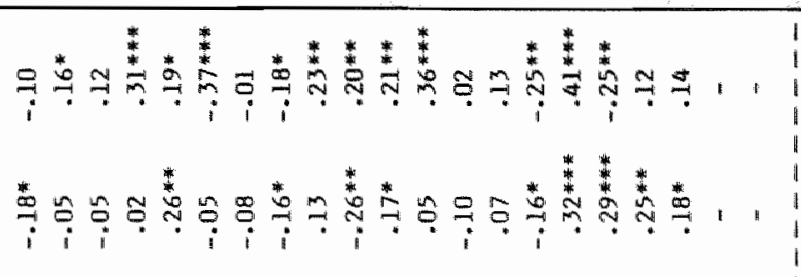 & 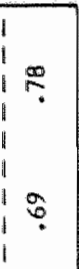 \\
\hline 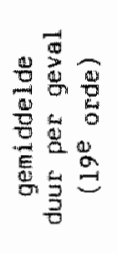 & 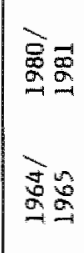 & 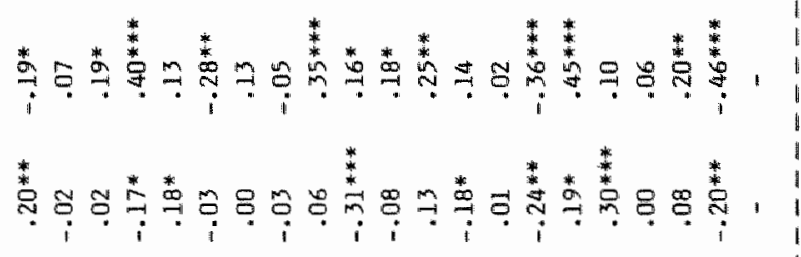 & 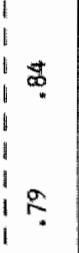 \\
\hline 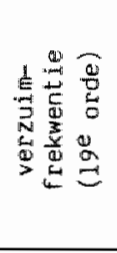 & 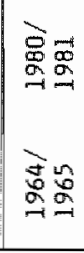 & 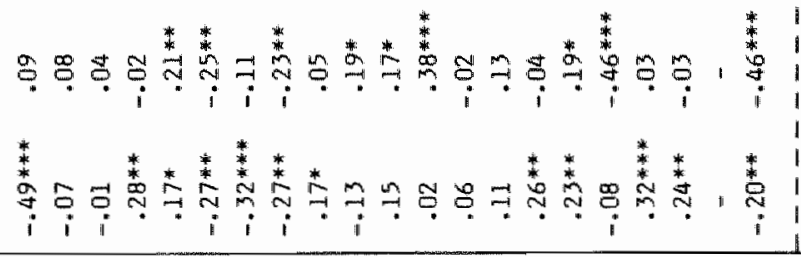 & $\begin{array}{l}\infty \\
\infty \\
\infty \\
\infty\end{array}$ \\
\hline 定 & & 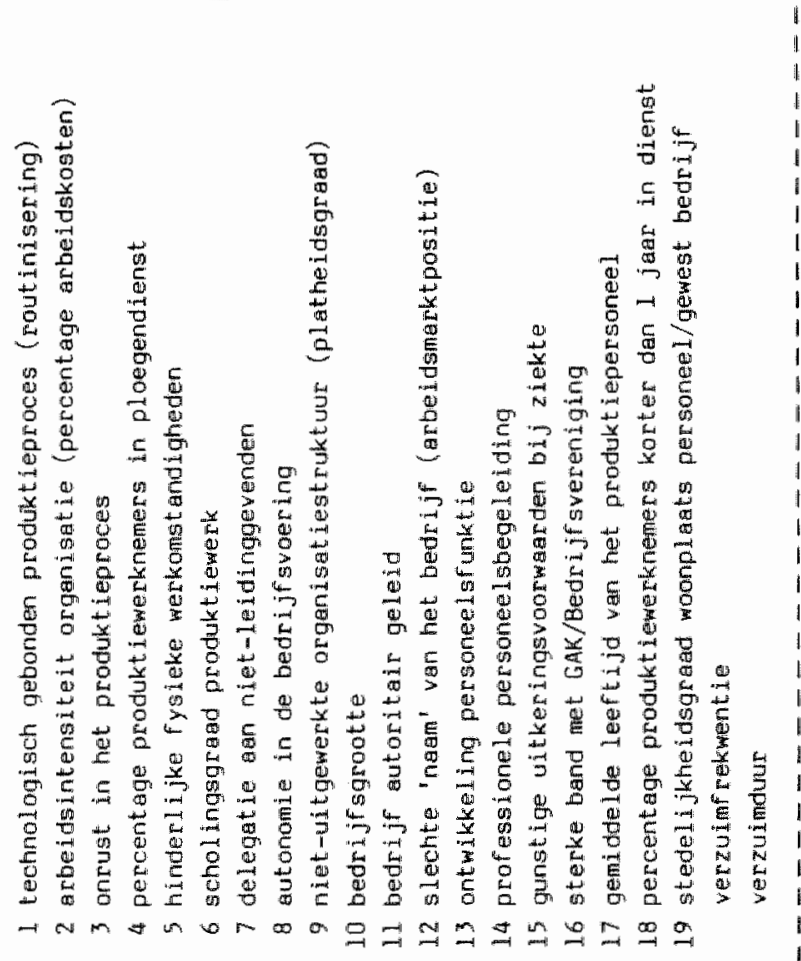 & 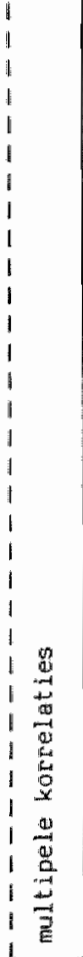 \\
\hline
\end{tabular}


dus nilet alleen de overblijvende achttien verklarende variabelen konstant gehouden, maar ook de 'alternatieve' verzuimmat.

Zoals op p. 148 vermeld, heeft deze ingreep het voordeel dat men hilerdoor op het spoor komt van die verklarende variabelen die de frekwentie-verschillen verklaren bij bedrijven met gelijke duur respektievelijk van die variabelen die de duur-verschillen verklaren bij bedrijven met gelijke frekwentie.

De negentiende-orde korrelatie wijkt duidelijk af van de achttiende-orde korrelatie, indien de alternatieve verzuimmat hoog korreleert met de betreffende verklarende variabele. Indien de alternatieve verzuimmat niet of bijna niet korreleert met de verklarende variabele, verschillen de achttiende- en negentiendeorde partiële korrelaties ook weinig of niet. Hieraan moet nog toegevoegd worden dat de verschillen tussen de achttiende- en negentiende-orde korrelaties sterker zijn indien de relatie tussen frekwentie en duur sterker is. Nu is deze laatste relatie in het 1980/81-onderzoek duidelijk hoger (partiële $r=-.46$ ) dan in het 1964/65-onderzoek (partiële $\mathbf{r}=-.20$ ). De verschillen tussen de achttiende- en negentiende-orde korrelaties zijn dan ook in het algemeen groter in het 1980/8l-onderzoek dan in dat van 1964/65. Tabel 6.5 laat zien dat de multipele korrelaties van de verklarende variabelen met de verzuimmaten in 1980/81 iets hoger zijn dan in $1964 / 65$. Bij de verzuimfrekwentie wordt 67 procent $\zeta=$ $.82^{2}$ ) van de variantie verklaard, bij de gemiddelde verzuimduur per geval 71 procent $\left(=.84^{2}\right)$ en bij het verzuimpercentage 61 procent $\left(=.78^{2}\right)$. Dit zijn hoge percentages; de multipele korrelaties zijn ook zeer signifikant $(p<.01)$.

Vervolgens richten we ons geheel op de vergelijking van de partiele korrelaties uit belde onderzoeken.

Net als bij de nulde-orde korrelaties kan nagegaan worden hoeveel procent van de korrelaties in beide onderzoeken signifikant is ( $p$ $<.10)$ of in beide onderzoeken niet-signifikant is. Tabel 6.6 geeft de resultaten.

Van alle 57 relaties wordt 42 procent bevestigd en 58 procent niet-bevestigd, indien dit temelijk hoog opgeschroefde criterium toegepast wordt. Hoog opgeschroefd, omdat bijvoorbeeld bij een relatie die in het eerste onderzoek net niet-signifikant is en in het tweede onderzoek net wèl, tot niet-bevestiging moet worden gekonkludeerd. 
Tabel 5.6 Wergelijking van de partiele korrelaties in beide onderzoeken

\begin{tabular}{|c|c|c|c|}
\hline resultaten & $\begin{array}{l}\text { verzuim- } \\
\text { frekwentie }\end{array}$ & $\begin{array}{l}\text { gemiddelde } \\
\text { duwr per geval }\end{array}$ & $\begin{array}{l}\text { verzuim- } \\
\text { percent age }\end{array}$ \\
\hline $\begin{array}{l}\text { resultaten in beide onderzoeken } \\
\text { signifikant of in beide niet- } \\
\text { signifikant }\end{array}$ & $8 \quad(42 \%)$ & $7 \quad 379$ & $9 \quad(47 \%)$ \\
\hline $\begin{array}{l}\text { resultaten in beide onderzoeken } \\
\text { verschillend }\end{array}$ & $11 \quad(58 \%)$ & $12(63 \mathrm{w})$ & $10 \quad(55 \%)$ \\
\hline totaal & $19 \quad(100 \%)$ & $19 \quad$ (1008) & $19 \quad(200 x)$ \\
\hline
\end{tabular}

Een minder hoog opgeschroefd criterium om uit te maken of de resultaten wit $1964 / 65$ verschillen van die uit $1980 / 81$ is toetsing van de verschillen tussen de partiële korrelaties.

Verschillen tussen partiële korrelaties uit verschillende steekproeven zijn door middel van transformatie van korrelatie-koëfficiënten in Fisher-Z-koëfficiënten te toetsen. Daaruit kan blijken of de verschillen tussen de paren korrelaties signifikant zijn. Volgens deze methode moet het verschil tussen de twee partiële korrelaties minimaal ongeveer .29 $\mathrm{zijn}$ (het precieze verschil is afhankelijk van de hoogte van de beide korrelaties), om op een nivo van $p=.10$ (tweezijdig) signifikant te zijn. Volgens dit criterium worden er 17 van de 57 oorspronkelijke partiële korrelaties niet bevestigd ( $=30$ procent). Hiermee wordt het niet-bevestigingspercentage teruggebracht van 58 procent bij de vorige methode tot 30 procent bij deze minder rigide methode. De signifikant van elkar veschillende korrelaties zijn in tabel 6.7 tussen haakjes vermeld.

Meer in detall is de konklusie hierbij dat 63 procent van de partiële relaties met de frekwentie, 74 procent van de partiële relaties met de gemiddelde duur per geval, en 74 procent van de partiële relaties met het verzuimpercentage als matig tot sterk bevestigd bestempeld kunnen worden.

Tenslotte is er nog een derde methode om de partiële korrelaties uit beide onderzoeken te bekijken. Men kan namelijk ook de korrelaties uit $1964 / 65$ en uit 1980/81 middelen. Hierbij wordt ervan uitgegaan dat het tweede onderzoek een goede replikatie van het eerste is en dat middeling dus toegestaan is. De gemiddelde korrelatie-koëfficiënten kan men ook weer op signifikantie toetsen. 


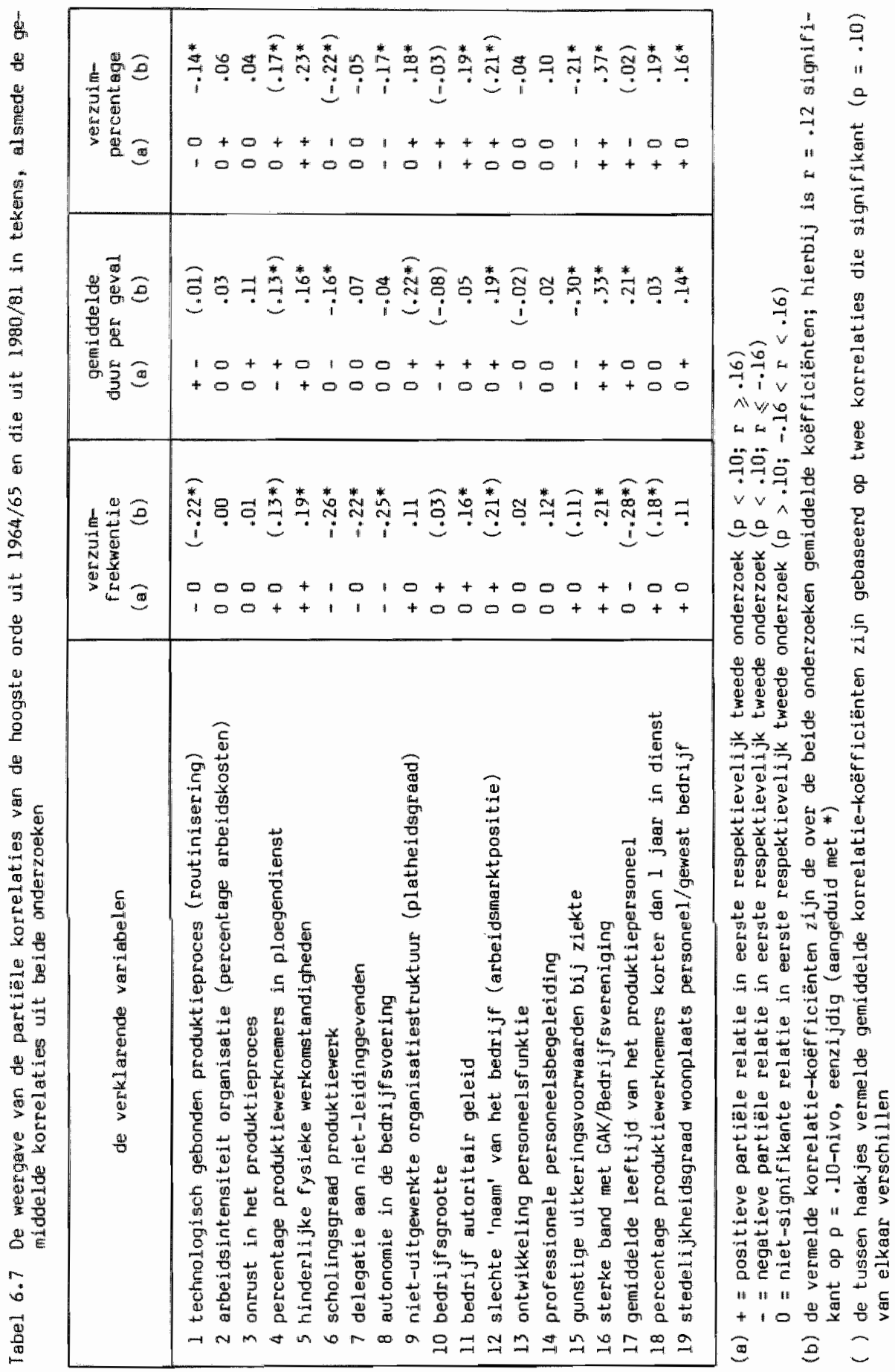


Door het feit dat deze gemiddelde waarden op twee onderzoeken berusten is een korrelatie-koëfficiënt dan reeds bij een lagere waarde signifikant.

De hierboven besproken gegevens $z i j n$ in tabel 6.7 samengebracht. Uit deze tabel ziet men dat - door de middeling - bij de verzuimfrekwentie twaalf van de negentien korrelaties signifikant zijn, bij de gemiddelde duur negen van de negentien en bij het verzuimpercentage twaalf van de negentien korrelaties. Ook zilet men dat een aantal van deze signifikante gemiddelde korrelaties op signifikant van elkaar verschillende korrelaties berusten. Deze korrelaties zijn tussen haakjes gezet en men dient ze als niet-bevestigd te beschouwen. Verder is ook war te nemen dat twee (net) niet-signifikante korrelaties door middeling kunnen leiden tot een signifikante korrelatie; dit is het geval bij de relatie(s) tussen variabele 14 (professionele personeelsbegeleiding) en de verzuimfrekwentie.

Op basis van de gegevens uit de tabellen 6.5 en 6.7 kan nu de balans opgenaakt worden.

\section{De verzuimf rekwentie}

op basis van beide onderzoeken kan men konkluderen dat de verzuimf rekwentie hoog is bij:

- hinderlijke fysieke werkomstandigheden $\quad(.17$ en .21$)$

- lage scholingsgraad van het werk (.27 en .25$)$

- geringe delegatie aan niet-leidinggevenden $(.32$ en .11)

- geringe autonomie in de bedrijfsvoering $(.27$ en .23$)$

- autoritaire leiding van het bedrijf (.15 en .17)

- professionele personeelsbegeleiding (.11 en .13)

- sterke band met GAK/Bedrijfsvereniging (.23 en .19)

Over de twee onderzoekingen als totaal gezien vertonen géén verband met de verzuimf rekwentie:

- arbeidsintensiteit van de organisatie

$(-.07$ en .08$)$

- onrust in het produktieproces

$(-.01$ en .04)

- niet-uitgewerkte organisatiestruktuur

$(.17$ en .05$)$

- ontwikkeling personeelsfunktie

$(.06$ en -.02$)$

- stedelijkheidsgread omgeving

$(.24$ en -.03$)$

$B i j$ de resterende zeven variabelen verschillen de resultaten van de twee onderzoeken signifikant $(p<.10)$ van elkaar: 
- grote mate ven routisinering

$$
\begin{array}{r}
(-.49 \text { en } .09) \\
(.28 \text { en }-.02) \\
(-.13 \text { en } .19) \\
(.02 \text { en } .38)
\end{array}
$$

- percentage ploegendienst-werknemers

- bedrijfsgrootte

- slechte 'naam' van het bedrijf

- gunstige uitkeringsvoorwaarden bij ziekte ( .26 en -.04)

- gemiddelde leeftijd produktiepersoneel (-.08 en -.46)

- percentage korter dan 1 jaer in dienst (.32 en .03)

\section{De gemiddelde verzuimduur per geval}

Op basis van beide onderzoeken kan van zeven variabelen gesteld worden dat ze een positief verband met de verzuimduur hebben:

- hinderlijke fysieke werkomstandigheden (.18 en .13)

- lage scholingsgraed van het werk (.03 en .28)

- slechte 'naam' van het bedrijf

(.13 en .25)

- ongunstige uitkeringsvoorwarden bij ziekte

$(.24$ en .36)

- sterke band met GAK/Bedrijfsvereniging

( .19 en .45)

- hoge gemiddelde leeftijd produktiepersoneel

$(.30 \mathrm{en} .10)$

- hoge stedelijkheidsgraad van de omgeving (.08 en .20)

Op basis van de geformuleerde criteria vertonen in tataliteit de valgende variabelen geen verband met de verzuimduur:

- erbeidsintensiteit van de organisatie

$$
\begin{aligned}
& (-.02 \text { en } .07) \\
& (.02 \text { en } .19) \\
& (.00 \text { en } .13) \\
& (-.03 \text { en }-.05) \\
& (-.08 \text { en } .18) \\
& (.01 \text { en } .02)
\end{aligned}
$$$$
\text { - onrust in het produktiepraces }
$$$$
\text { - delegatie an niet-leidinggevenden }
$$$$
\text { - autonomie in de bedrijfsvoering }
$$$$
\text { - autoritaire leiding van het bedrijf }
$$$$
\text { - professionele personeelsbegeleiding }
$$

- percentage korter dan 1 jaar in dienst

$(.00$ en .06$)$

Ten aenzien van de resterende vijf variabelen verschillen de resultaten van beide onderzoeken, wat betreft de relatie met de gemiddelde verzuimduur, signifikant van elkaar:

- grote mate van routinisering

$$
(.20 \text { en }-.19)
$$

- percentage ploegendienst-werknemers

$(-.17$ en

- niet-uitgewerkte organisatiestruktuur

$(.06$ en

- bedrijfsgrootte

$(-.31 \mathrm{en} \mathrm{.16)}$

- ontwikkeling personeelsfunktie

$(-.18$ en .14$)$ 


\section{Het verzuimpercentage}

Op basis van beide onderzoeken kan men tot een positief verband met het verzuimpercentage besluiten bij de volgende negen variabelen:

- geringe mate van routisinering

$(.18$ en .10)

- hinderlijke fysieke werkomstandigheden

$(.26 \mathrm{en} .19)$

- geringe autonamie in de bedrijfsvoering

(.16 en

- niet-uitgewerkte organisatiestruktuur

$(.13 \mathrm{en}$

- autoritaire leiding van het bedrijf

(.17 en .21)

- ongunstige uitkeringsvoorwaarden bij ziekte

$(.16 \mathrm{en} .25)$

- sterke band met GAK/Bedrijfsvereniging

- hoog percentage korter dan 1 jaar in dienst

$(.32$ en .41$)$

$(.25$ en .12$)$

- hoge stedelijkheidsgraad van de omgeving (.18 en .14)

Geen verband met het verzuimpercentage hebben dan de variabelen:

- arbeidsintensiteit van de organisatie

$(-.05$ en .16)

- onrust in het produktieproces

$(-.05$ en .12$)$

- delegatie aan niet-leidinggevenden

$(-.08$ en -.01$)$

- ontwikkeling personeelsfunktie

$(-.10$ en .02$)$

- professionele personeelsbegeleiding

$(.07$ en .13)

Bij de vijf andere variabelen verschillen de resultaten van de twee onderzoeken signifikant van elkaar:

- percentage ploegendienst-werknemers

$(.02$ en .31$)$

- schollingsgraad van het werk

$(-.05$ en -.37$)$

- bedrijfsgrootte

- slechte 'naam' van het bedrijf

$(-.26$ en .20$)$

- gemiddelde leeftijd produktiepersoneel

$(.05$ en .36$)$

$(.29$ en -.25$)$

\subsection{Bespreking van de gevonden verschillen}

In de bespreking van de gevonden resultaten zullen de volgende twee onderwerpen aan de orde gesteld worden:

- de signifikante verschillen tussen de onderzoeken uit 1964/65 en 1980/81 (paragraaf 6.4);

- de toetsing van de hypothesen van Philipsen (1.969) vanuit het gezichtspunt van de zeven door hem opgestelde 
kerngedachten en vanult het perspektief van de twee komponenten van het verzuim, de frekwentie en de gemiddelde duur per geval (paragraaf 6.5).

Dus eerst het kommentaar op de duidelijke niet-bevestigde verbanden. Dit waren er zeven met de frekwentie, vijf met de gemiddelde duur en vijf met het verzuimpercentage. In het algemeen kan er hier, ter inleiding nog aan herinnerd worden dat, als het $1980 /$ 81-onderzoek duidelijk andere resultaten oplevert dan het 1964/ 65-onderzoek, dit te wijten kan zijn aan het feit dat de gemiddelden en standaard-deviaties van de betreffende variabelen signifikant veranderd zijn. Dok kan het te wijten zijn aan de inwerking van niet-gemeten variabelen. In dit verband werd de konjunktuur en het percentage buitenlandse werknemers genoemd. Tenslotte kan de inmiddels gekonstateerde kromlijnigheid van een par verbanden in de instabiliteit een rol hebben gespeeld.

Bij de variabele routisinering van het produktieproces doet zich min of meer een omslag voor in de richting van de verbanden met de frekwentie en de duur; in $1964 / 65$ bestond er een negatief verband met frekwentie en een positief verband met de duur, terwijl in $1980 / 81$ een neiging tot het omgekeerde bestaat. Deze omslag heeft maar weinig effekt op het verzuimpercentage.

Eerder in dit hoofdstuk is gebleken dat de relatie van routisinering met de verzuimfrekwentie in $1980 / 81$ een U-relatie is. De lineaire komponent van de relatie geeft dus maar 'een deel' van het werkelijke verband weer. Door het kromlijnig verband wordt de korrelatie-koëfficiënt instabiel, dat wil zeggen kan gemakkelijker verschuiven, afhankelijk van het deel van de schaal waarin gemeten wordt. Dit verkleart misschien het verschil tussen 1964/ 65 en 1980/81 op het punt van de frekwentie.

Het gevonden kromlijnige verband is trouwens overeenkomstig hetgeen Philipsen destijds als hypothese formuleerde: bij enkelstuks- en massaproduktie met veel respektievelijk weinig vrijheid in werktempo en onderbrekingen is de verzuimfrekwentie hoger dan bij serie- en procesproduktie met een gemiddelde vrijheid.

Bij ploegendienst doet zich ook een omslag in de richting van de verbanden voor. In $1964 / 65$ bleek ploegendienst frekwentieverhogend en in 1980/81 bleek het duur-verlengend. De sterke relatie met de gemiddelde duur per geval leidde in 1980/81 ook tot een 
signifikent positief verband met het verzulmpercentage, hetgeen in $1964 / 65$ niet het gevel wes.

Ook uit de onderzoeksliteratuur blijkt dat de relatie dag-/ploegendienst met verzuim notoir instabiel is. Er is bijna even veak gevonden dat verzuim (alle drie maten) bij ploegendienst hoger is dan bij de degdienst (bijvoorbeeld Jardillier, 1962; Gadourek, 1965; Hoolwerf et $81 *$, 1974; Legge *Hiling, 1974: Colligan et al., 1979; Angersbach et al.,1980; Kruldenier, 1982) als dat verzuim bij ploegendienst lager is dan bij degdienst (bijvoorbeeld Wyatt * Marriott, 1953; Wade, 1955; Shepherd * Walker, 1956; Thils-Evensen, 1958; Aanonsen, 1964; Tan, 1967; Taylor, 1967; Chevrolle, 1969; Taylor et al., 1972; 0'Muircheartaigh, 1975; Smulders, 1985). Behalve dat deze verschillen te maken kunnen hebben met vaak niet onder kantrole gehouden arbeldssituatie-kenmerken, als aspekten van ploegendienstroosters, ploegendienstpremies, werkomstandigheden, 'teamgeest', etcetera (Smulders, 1983) kunnen ze ook te maken hebben met het feit dat vórselektie op grond van gezondheid en geschiktheid een rol speelt bij het soms lage verzuim van ploegendienstwerkers. Door het feit dat werknemers die het werken in ploegendienst geestelijk of lichamelijk niet meer op kunnen brengen, vaak teruggeplaatst worden in dagdienst, blijft de kategorie ploegendienstwerkers dus een permanent op gezondheid geselekteerde werknemergkategorie.

Transversale vergelijking van het verzuim van dagdienst- en ploegendienstwerkers is dus elgenlijk niet de meest optimale onderzoeksmethode. In ieder geval zou dearbij diensttijd, werkomstandigheden en gezondheidstcestand onder kontrole gehouden moeten worden. Een betere methode is om te kijken hoe het verzulm zich ontwikkelt bij langere 'expositie' aan ploegendienstwerk of een vergelijking te maken tussen dag- en ploegendienstwarkers met even lange 'expositie'.

Scholingsgread van het werk bleek in 1980/81 niet alleen negatief met de frekwentie maar ook met de gemiddelde dur samen te hangen, waerdoor ook een negetief verband met het verzuimpercentage ontstond. Dat laatste was in het onderzoek van Philipsen niet het geval. Dok 0'Muircheartaigh (1975), Kruidenier (1982) en Nijhuis en Soeters (1982) vonden negatieve verbanden met de duur. Barr (1967), Schmidt (1967), Mann et al. (1971) en Ris (1978) vonden een positief verband tussen scholingsgraad en verzuinduur. Blijk- 
baar is de relatie scholing - verzuimdur nogal situatie-gebonden.

Bovendien hebben we reeds eerder gekonstateerd dat de relatie scholingsgraad - verzuimpercentage in 1980/81 kromlijnig is (een omgekeerde U-relatie), waardoor de korrelatie-koëfficiënt weer sterker afhankelijk is geworden van het deel van de schaal waarin gemeten wordt.

Dat platte organisaties een hogere verzulimf rekwentie zouden hebben den stelle organisaties veronderstelde Philipsen destijds. Hij (1969, p. 123-127) heeft beargumenteerd dat in platte organisaties minder kansen zijn op bevredigende horizontale en vertikale menselijke verhoudingen en dat er minder kansen zijn op stabiele werkverhoudingen. Beide onstandigheden leiden, volgens Philipsen, tat een geringere binding aan het werk en een hoger verzuim, welke hypothese in $1964 / 65$ bevestigd werd met de frekwentie en in 1980/81 met de verzuinduur.

Dverigens vinden Nijhuis en Soeters (1982) ook enige positieve verbandien tussen de platheid van de organisatie en de frekwentie en de gemiddelde duur. Platheid van de organisatie is dus blijkbaar niet zo'n typisch frekwentie-bepalende variabele als oorspronkelijk gedacht werd.

De grootste verschillen tussen de beide onderzoeken betreffen de resultaten met betrekking tot de bedrijfsgrootte. Bij alle drie de verzuimmaten zijn de resultaten uit 1964/65 signifikant verschillend van die uit $1980 / 81$. In het eerste onderzoek waren alle relaties negatief, in $1980 / 81 \mathrm{z} \mathbb{1}$ jn alle relaties juist positief. Wat zegt de onderzoeksliteratuur in het algemeen op dit punt? Uit het merendeel van het eerder uitgevoerde empirisch onderzoek over de invloed van bedrijfsgrootte op verzuim is gebleken dat de relatie tussen grootte en het verzuimpercentage respektievelijk de frekwentie positief is (Acton Society Trust, 1953; Liddell, 1954; Acton Soclety Trust, 1957; Revans, 1958; Baumgartel \& Sobol, 1959; Revens, 1964; Indik, 1965; Ekker, 1966; Ingham, 1970; Sumsion, 1974; 0'Muircheartaigh, 1975; Ten Broeke, 1976; Dijkstra, 1977; Miner, 1977; Calllard et al., 1978; Kovach, 1978; Reiche \& Van Dijkhuilzen, 1979; Winkler, 1980; Allen, 1981; Smulders, 1983). Dver het algemeen wordt het positieve verband met deze verzuimmaten geweten aan de grotere bureaukratie, de minder per- 
soonlijke relaties en kommunikatie en de sterkere specialisatie in grotere organisaties.

Met de gemiddelde verzuimduur per geval lijkt de relatie veel minider duidelijk. Door Ekker (1966) en Philipsen (1969) werden negatieve verbanden gevonden. Baumgartel en Sobol (1959), 0'Muircheartaigh (1975), Dijkstra (1977), Ris (1978) en Nijhuis en Soeters (1982) vonden niet-signifikante relaties van organisatiegrootte met de gemiddelde duur per geval, en Ten Broeke (1976) en Nijhuis en Soeters (1982) vonden tenslotte een positief verband. De relatie van de verzuimduur is mogeijk afhankelijk van duurbeperkende of -verlengende omstandigheden die sorns wel en soms niet met grootte samengaan (zoals ploegendienst, ontwikkeling van de personeelsfunktie, band met GAK, etcetera, zie tabel 6.1 , p. 151). Samenvattend kan gesteld worden dat de in 1980/81 gevonden relaties van bedrijfsgrootte met frekwentie en verzuimpercentage méér door eerdere empirische onderzoeksresultaten ondersteund worden dan de in 1964/65 gevonden verbanden.

Ook de resultaten met betrekking tot de variabele slechte 'naam" van het bedrijf pakken anders uit dan in 1964/65. In tegenstelling tot het onderzoek uit die periode $z i j n$ de relaties met alle drie de verzuimmaten thans positief, hetgeen een nogal plausibel resultaat genoemd mag worden. Overigens moet men bij de variabele 'naam' waarschijnlijk ten dele aan kausaliteit denken en ten dele aan kovariatie met verzuim. Philipsen formuleerde om gelijkssoortige reden geen hypothese ten aanzien van de relatie 'naam" verzuim. Men zou dus ook kunnen verdedigen dat de variabele 'naam' slechts ten dele thuis hoort in de rij van determinanten van verzuim, gezien het feit dat 'naam' weer bepaald wordt door een ruim aantal andere - ook opgenomen - variabelen (zie tabel 6.1).

Vervolgens blijken de korrelaties tussen de variabele ontwikkeling van de personeelsfunktie en verzuimduur in beide onderzoeken signifikant van elkaar te verschillen. Mar omdat beide korralaties op zich niet-signifikant zijn, zal dit verschil niet verder besproken worden. Het algemene beeld blijft dus hetzelfde als in 1964/65: de mate van ontwikkeling van de personeelsfunktie hangt met geen van de drie verzuimmaten samen. 
Gunstige uitkeringsvoorwaarden bij ziekte bleken in 1964/65 signifikant frekwentie-bevorderend te zijn, maar in 1980/81 niet meer. Omdat echter deze variabele in 1964/65 nog zowel op wachtdagen als op loonvergoeding bij doktersbezoek betrekking had, terwijl de variabele in 1980/81 in feite alleen op loonvergoeding bilj doktersbezoek sloeg, moet aan vergelijking van de resultaten uit beide onderzoeken niet teveel waarde gehecht worden.

De verschuivingen rond de variabele gemiddelde leeftijd van het personeelsbestand kunnen wel als apvallend bestempeld worden. Bedrijuen met een relatief oud personeelsbestand blijken in 1980/ 81 een signifikant lagere verzuimfrekwentie en een lager verzuimpercentage te hebben dan bedrijven met een relatief jong personeelsbestand. Daarentegen werd er in 1964/65 een positief verband gevonden tussen leeftijd en het verzuimpercentage (door het positieve verband met de verzuimduur).

Het negatieve verband van leeftijd met de frekwentie in 1980/81 is reeds letterlijk tientallen keren eerder in onderzoek vastgesteld. Dat resultakt is dus niet opvallend. Het ontbreken van het signifikant positief verband met de gemiddelde verzuimduur (bij konstant-houding van de frekwentie) is wel opvallend. In bijna al het vorig onderzoek, zoals ook bij Philipsen, is de relatie leeftijd - duur positief. Door het ontbreken van dit positieve verband, alsmede door de kracht van het negatieve verband met de frekwentie, is de relatie tussen leeftijd en het verzuimpercentage in 1980/81 negatief. Dit is, met uitzondering van $\mathrm{Nijhuis} \mathrm{en}$ Soeters (1982) en Smulders (1983), zelden in Nederlands onderzoek gevonden. Wel in buitenlands onderzoek warin de lengte van de verzuimduur oin ziektewettechnische redenen meestal korter is en dus een minder sterke invloed heeft op het verzuimpercentage (bijvoorbeeld Sinha, 1956; Knox, 1961; Collins, 1962; IsambertJamati, 1962; Nicholson et al., 1977a; Johns, 1978; Spencer en Steers, 1980; Baker en Pocock, 1982).

Er moet op geattendeerd worden dat het ontbreken van de positieve relatie leeftijd - verzuimduur in 1980/81 mede te maken heeft met de extreem hoge negatieve relatie tussen leeftijd en verzuimfrekwentie, wardoor het grote verschil ontstaat tussen de nulde-orde relatie $(r=.39)$ en de hoogste orde relatie $(r=.10)$ wat betreft leeftijd - verzuimduur. Zie voor details in de tabellen 6.4 (p. 157) en 6.5 (p. 161). 
Tenslotte kan vermeld worden dat de relaties tussen de variabele veel werknemers met korte diensttijd en de verzuimfrekwentie in beide onderzoeken signifikant van elkaar verschillen. Het sterk positieve verband dat in 1964/65 bestond, ontbrak in 1980/81. Dit laatste is ook het geval bij Nijhuis en Soeters (1982). Het niet-signifikant zijn heeft overigens niets te maken met partiële-korrelatierekening en mogelijke wegdrukking van de variabele diensttijd door leeftijd, want de nulde-orde korrelatie tussen diensttijd en frekwentie is reeds laag $(r=.14$, tabel 6.4, $p$. 157).

Tot zover de bespreking van de duidelijk niet bevestigde verbanden.

\subsection{Ioetsing van de hypothesen}

In tabel 6.8 zijn de door Philipsen ontwikkelde - en in dit onderzoek overgenomen - hypothesen vermeld per hoofdkoncept en per variabele. Tevens zijn in deze tabel de resultaten uit 1964/65 en uit $1980 / 81$ bij de variabelen vermeld. Daarbij is weer een partiele korrelatie van $r=.16$ (welke een kans van tien procent heeft aan toeval te wijten te zijn) als silgnifikant aangemerkt.

Zoals in het begin van hoofdstuk 5 werd uiteengezet, heeft Philipsen (1969) zeven theoretische begrippen gebruikt on de verschillen in verzuim tussen bedrijven te verklaren. Omdat twee van deze begrippen (de oriëntatle van de werknemers en de kansen op sociale kontrole van het afwezigheidsgedrag) uiteindelijk inet dezelfde variabelen geoperationaliseerd konden worden, verloopt de theoretische verklaring van de verzuimverschillen via zes in plaats van zeven hoof dkoncepten.

Philipsen formuleerde 23 hypothesen met betrekking tot de relaties tussen achttien verklarende variabelen en de verzuimfrekwentie en negen hypothesen over de relaties tussen zeven verklarende variabelen en de gemiddelde duur per geval. Ten aanzien van een zevental van deze variabelen werden (dezelfde) hypothesen geformuleerd vanuit het gezichtspunt van meerdere hoofdkoncepten. Ploegendienst bijvoorbeeld komt voor onder afwezligheldsnoodzaak en ook onder kansen op instrumentele binding. Op basis van de ge- 
Tabel 6.8: Toetaling wan de hypotheaen van PhLlipsen (1969)

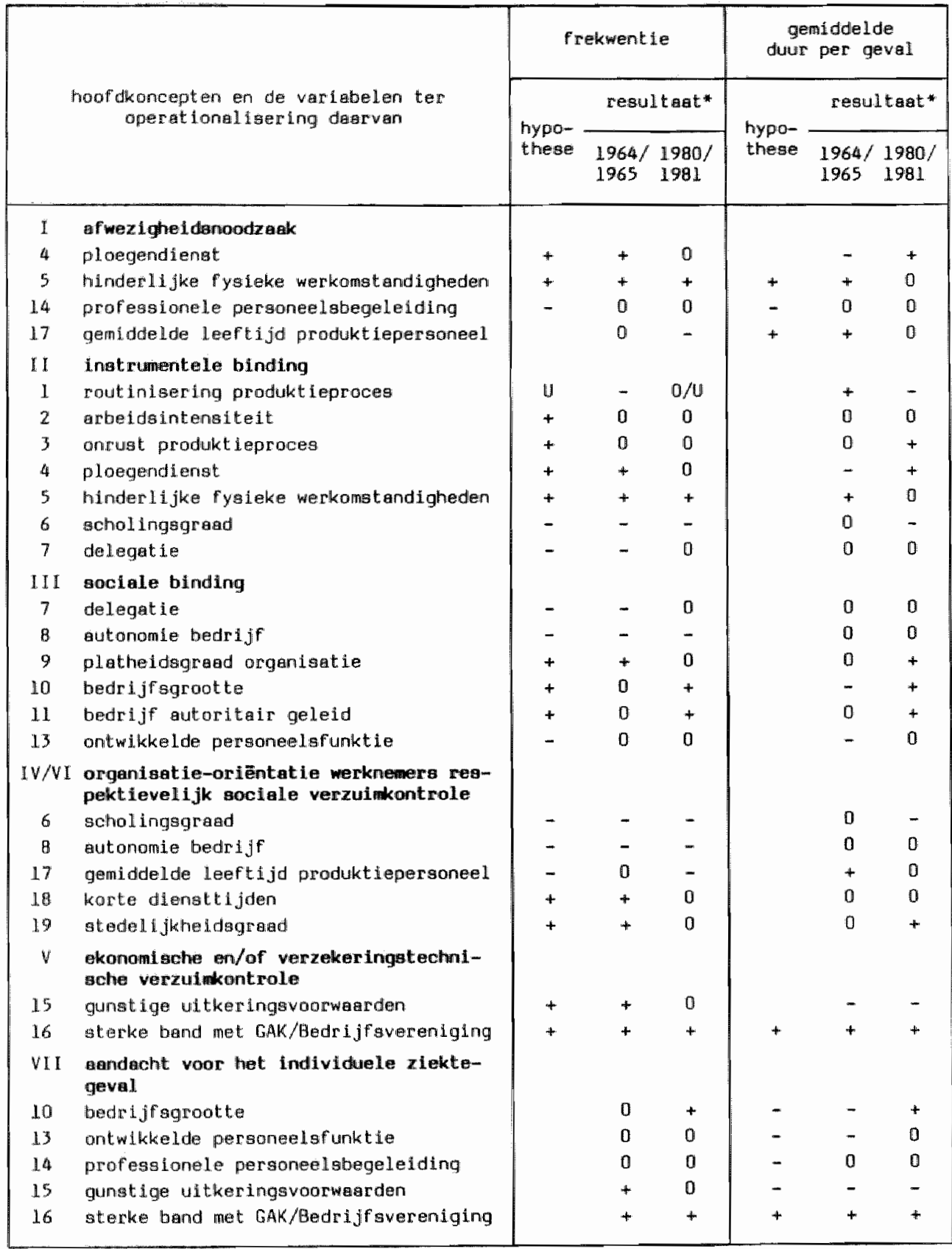

* de partiele korrelatles $\geqslant .16$ ( $p=.10$, eenzijdige toetsing zijin met een + of vermeld; biji variabele 1 (routinisering) is tevens de kromlijnige nulde-orde korrelatie met de frekwentie in 1980/81 vermeld (U) 
gevens in tabel 6.8 blijkt nu dat van deze 32 relaties or in totaal tien ( $=31$ procent) in beide onderzoeken bevestigd werden, zestien relaties ( $=50$ procent) in slechts én van de twee onderzoeken en zes relaties ( $=19$ procent) in geen van beide. Voor de zes hoofdkoncepten zijn deze gegevens in tabel 6.9 samengevat.

Tabe1 6.9 Toetsing van de hypothesen in samengevatte vorm

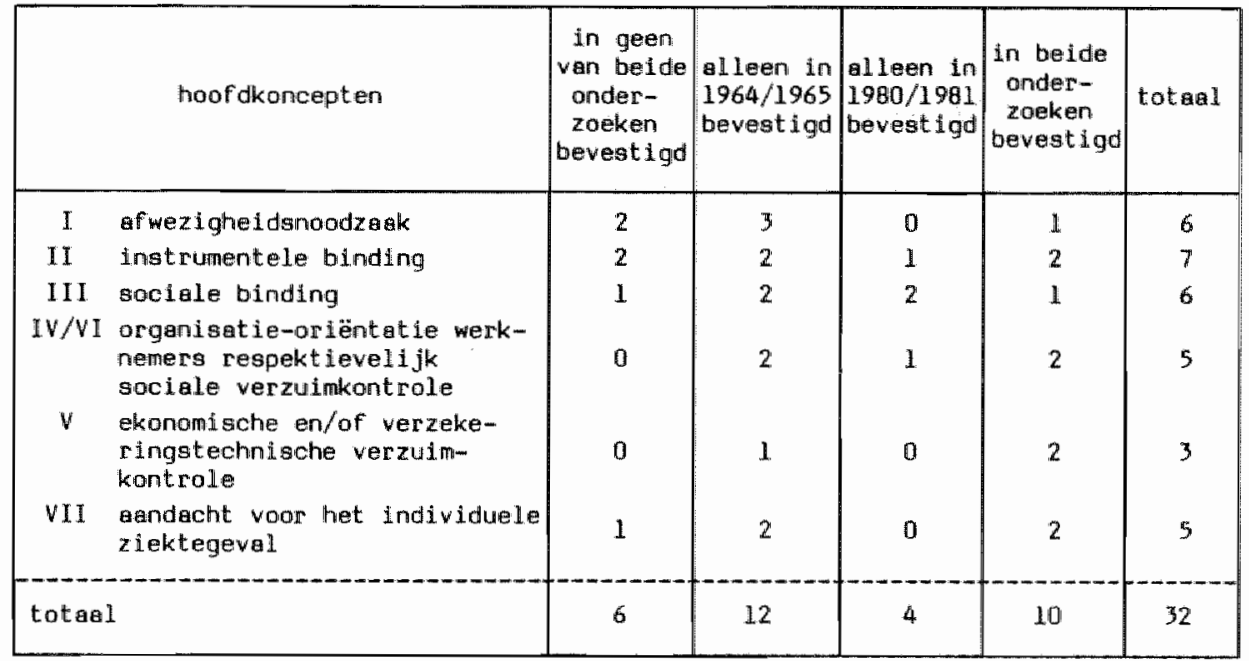

Uit deze tabel blijkt dat geen van de zes hoofdkoncepten een duidelijk betere voorspellende waarde heeft ten aanzien van verzuimfrekwentie en verzuimduur dan de andere hoofdkoncepten. Dus onder alle zes hoofdkoncepten treft men zowel een aantal bevestigde als niet-bevestigde hypothesen aan. Tevens betekent dit dat gén van de hoofdkoncepten als theoretisch niet-relevant aangemerkt kan worden. De resultaten van beide onderzoeken te zamen blijven dus - niet op alle punten, maar wel in globale zin - de verzuimtheorie van Philipsen ondersteunen. Men zou dit als een van de belangrijkste konklusies kunnen beschouwen uit het replikatie-onderzoek.

Vervolgens een aantel opmerkingen over de gevoeligheid van de verzuimfrekwentie-mat en de verzuimduur-mat voor de opgevoerde verklarende variabelen.

In de gedachtengang van Philipsen (1969) werd van de negentien 
verklarende variabelen - met uitzondering van de variabele "naam" - verondersteld dat ze een duidelijk positieve of negatieve relatie met de verzuimf rekwentie zouden hebben.

Reeds in Philipsen's eigen onderzoek bleek deze gedachte niet geheel juist te zijn. Arbeidsintensiteit van de organisatie, onrust, organisatiestruktuur, ontwikkeling personeelsfunktie en stedelijkheidsgraad blijken - op basis van beide onderzoekingen te zamen - niet of weinig van belang te zijn voor de verklaring van de verzuimfrekwentie. En van een zevental variabelen is de invloed op de frekwentie twijfelachtig geworden, gezien de tegengestelde resultaten uit het 1980/81-onderzoek.

Kortom, de verzuimfrekwentie lijkt minder gevoelig te reageren op de opgevoerde variabelen dan oorspronkelijk gedacht was.

Een eerste punt hierbij is dat het erop lijkt dat instrumentele binding aan de werksituatie (onder meer geïndiceerd door arbeidsintensitelt, onrust en de platheid/steilheid van de organisatie) van minder belang lijkt voor de verzuimfrekwentie dan oorspronke$1 i j k$ werd gedacht. Waarschijnlijker is echter dat genoemde drie variabelen niet al te veel met instrumentele binding aan de werksituatie te maken hebben, want uit onderzoek op individueel nivo is overduidelijk gebleken det instrumentele binding - geindiceerd door de taakinhoud - de verzuimfrekwentie sterk bepaalt (zie bijvoorbeeld Hackman \& 0ldham, 1976; Algere, 1980).

Dok kan in dit verband gewezen worden op de invloed van de variabelen routisinering, scholingsgraad van het werk en delegatie in dit onderzoek.

Een tweede punt is dat de omvang en de aktiviteiten van de personeelsafdeling van een bedrijf blijkbaar minder invloed op de frekwentle uitoefenen dan oorspronkelijk was verondersteld (zie de niet-signifikante of zeer zwakke relaties met de frekwentie, en trouwens ook met de duur, van de variabelen personeelsfunktie en personeelsbegeleiding).

Wat betreft de geniddelde verzuimduur per geval doet zich in zekere zin een tegengesteld verschijnsel voor. Ten aanzien van deze verzuimmat stelde Philipsen destijds dat daar slechts zeven van de negentien variabelen op van invloed zouden zijn (werkomstandigheden, bedrijfsgrootte, de personeelsfunktie, personeelsbegeleiding, uitkeringsvoorwaarden, band met GAK/Bedrijfsvereniging en leeftijd). Bij vijf van deze variabelen is dat globaal ook 
julst gebleken. Bij de varlabele bedrijfsgrootte staken de steminen en bij de variabele personeelsbegeleiding bleek de hypothese onjuist.

Maar bovendien lijkt het erop dat er verschillende andere variabelen zijn die ook verband houden met de duur. Het gaat hier om de scholingsgraed van het werk, de stedelljkheldsgraed van de ongeving van het bedrijf, en de 'naam' van het bedrijf.

Het lijkt erop dat gekonkludeerd moet worden dat, wat Philipsen de markt- of organisatie-oriëntatie van het personeel noemde, van groter belang is voor de verzuimduur dan bij de hypothesevorming werd aangenomen. Werknemers met een lage scholingsgraad en werknemers uit stedelijke gebieden, die volgens Philipsen gekarakteriseerd worden door een markt-oriëntatie in plaats van een organisatie-oriëntatie, blijken volgens de onderzoeksresultaten namelijk geneigd te zijn tot langere ziekteduren (dit is het sterkst het geval in het 1980/81-onderzoek). Mogelijk is ook dat bij de invloed van deze variabelen op de verzuimduur de geringe sociale kontrole van het afwezigheidsgedrag van aangeduide twee personeelskategorieën een rol speelt (Philipsen, 1969, p. 119, 145).

Dit alles leidt tot de konklusie dat de gemiddelde verzuimduur per geval gevoeliger is voor de opgevoerde variabelen dan bij de hypothesevorming oorspronkelijk werd aangenomen.

Dok kan nog een waarschijnlijke aanvulling op de theorie van Philipsen geformuleerd worden. In zijn theorie ging hij er namelijk van uit dat instrumentele en sociale binding van werknemers an de werksituatie alleen invloed had op de verzuimfrekwentie. Het in 1980/81 ulitgevoerde onderzoek lijkt echter duidelijk ook naar de verzuimduur te wijzen. De variabelen onrust, ploegendienst, scholingsgraad, organisatiestruktuur, bedrijfsgrootte en de wijze van leidinggeven aan het bedrijf (die er in principe voor in aanmerking komen am instrumentele en sociale binding te vertegenwoordigen) blijken namelijk in 1980/81 alle - hoewel soms zwak samen te hangen met de gemiddelide duur per geval. Ook bij Ris (1978) waren trouwens reeds aanwijzingen te vinden voor de nauwe relatie tussen binding aan de werksituatie en de verzuimduur.

6.6 De validiteit van de verklarende variabelen

De gebruikswarde van een meetinstrument wordt niet alleen be- 
paald door zijn betrouwbarheid, maar ook door zijn validiteit. Betrouwbaarheidsaspekten van de variabelen kwamen reeds in hoofdstuk 5 an de orde. Thans zullen we de validiteit bespreken. Het gaat daerbij am de vraag of de variabele het begrip-zoals-bedaeld representeert. Twee vormen van validiteit kunnen onderscheiden worden: inhoudsvaliditelt, die het instrument wordt toegeschreven indien het korreleert met reeds als valide aanvaarde soortgenoten, en criterium-validiteit, die het wordt toegeschreven als er een criterium-variabele (bijvoorbeeld ziekteverzuim) goed mee voorspeld kan worden.

Op basis van de twee genoemde criteria kan nu de validiteit van de negentien verklarende variabelen beoordeeld worden. Als informatiebron voor de inhoudsvaliditeit kunnen de korrelatiematrices uit 1964/65 (Bijlage III) en uit $1980 / 81$ (tabel 6.1, p. 15.1) gebruikt worden. Hiermee kan nagegaen worden welke variabelen in de tijd, ten opzichte van de andere, relatief stabiel blijven en welke relatief sterk veranderen in hun relatiepatroon.

Deze vorm van vergelijking kan ook aangeduid worden met de term 'cross-validatie', waarbij instabiliteit dus gezien wordt als een indikatie van invaliditeit. Dit is een precaire, explorerende aktiviteit omdat stabiliteit van relatiepatronen niet altijd op validiteit hoeft te wijzen; invalide variabelen zouden in principe ook tweemaal op dezelfde wijze met de andere variabelen kunnen samenhangen.

Verder zij nog opgemerkt dat minder betrouwbare instrumenten (zie paragraaf 5.3) ook sneller een kans maken invalide te zijn. Dus betrouwbaarheidsgegevens kunnen (in)validiteit verklaren.

Allereerst blijkt nu dat een antal variabelen in de tijd een stabiel patroon vertonen. Dit betreft vooral het type produktieproces, arbeidsintensiteit, ploegendlenst, werkomstandigheden, scholingsgraad en stedelijkheidsgraad. De stabiliteit geeft grand aan de gedachte dat we hier te maken hebben met de relatief meest valide variabelen.

Eveneens kan gekonkludeerd worden dat de min of meer subjektief gemeten variabelen - door middel van interviews met de bedrijfsleider en de personeelschef - zich stabiel gedragen, hetgeen de validiteit van dit soort instrumenten ondersteunt. Het gaat hier bijwoorbeeld om delegatie, autoritaire bedrijfsleiding en 'naam' van het bedrijf. 
De volgende vijf variabelen blijken het meest instablel te zijn:

- Onrust in het produktieproces (3) dat, anders dan in $1964 / 65$ in $1980 / 81$ blljkt samen te gean met slechte 'naam' van het bedrijf, kleine bedrijfsgrootte, weinig ontwikkelde personeelsfunktie, sterke band met GAK/Bedrijfavereniging en relatief veel personeel met korte diensttijden.

De veranderingen in de relatiestruktuur van deze variabele doen echter niet vreemd aan. 'Onrust' zegt dus in $1980 / 81$ niet alleen lets over het produktieproces, maar tevens over bijvoorbeeld de wervingskracht van de organisatie (zie de faktoranalyse, tabel 6.2, p. 153). Mogelijk is de relatief lage interne konsistentie van de variabele in 1980/81 debet aan de veranderde inhoud.

- Platheidsgraad van de organisatie (9) boet inhoudelijk aan begrijpelijkheid in. Deze variabele verliest in $1980 / 81$ namelijk zijn sterke verbanden met arbeidsintensiteit, autonomie, autoritaire bedrijfsleiding, ongunstige uitkeringsvoorwarden en sterke band met GAK/Bedrijfsvereniging. Daarmee 1 s platheidsgraad gén uiting meer van traditionele organisatiewijze, zoals dat in $1964 / 65$ het geval was.

- Bedrijfagrootte (10) blijkt eveneens een weinig stablele variabele. In 1964/65 lagen grote organisaties in stedelijke gebieden, hetgeen in het later onderzoek niet meer het geval is. Anders dan in 1964/65 worden grote organisaties thans gekenmerkt door veel rust, veel ploegendienst, welnig autonomie in de bedrijfsvoering, een goede 'naam' en een relatief jong personeelsbestand. Volgens de faktoranalyse (tabel 6.2 ) was bedrijfsgrootte in $1964 / 65$ de centrale variabele in de faktor bedrijfsgrootte en 18 deze in 1980/81 een kenmerk van moderne organisatiewijze. Het enige wat organisatiegrootte in beide onderzoekingen gemeen heeft is de variabele ontwikkelde personeelsfunktie.

De veranderingen die zich hebben voorgedean in de relatiestruktuur van bedrijfsgrootte 1ijken niet onbegrijpe$1 i j k$, maar dat neemt niet weg dat we inhoudelijk met een andere variabele te maken lijken te hebben.

- Profeasionele peraoneelsbegeleiding (14) ls ook duide- 
$11 \mathrm{jk}$ van inhoud veranderd. In het oorspronkelijke onderzoek kwam deze aktiviteit sterk voor in niet-autonome bedrijven met een ontwikkelde personeelsfunktie, gunstige uitkeringsvoorwarden en een jong personeelsbestand. Dit is in 1980/BI niet meer het geval. Deze vorm van begeleiding komt in het latere onderzoek juist mér voor in bedrijven met een relatief oud personeelsbestand. Alles bij elkar is professionele personeelsbegeleiding geen indikatie meer van moderne organisatiewijze, zoals dat in 1964/65 wel het geval was.

Reeds eerder is gesignaleerd dat de variabele in het latere onderzoek eigenlijk alleen selektie- en beoordelingsstrengheid indiceert. Dit zal waarschijnlijk te maken hebben met de instablliteit van de relatiestruktuur.

- Leeftijd (17): een gemiddeld oud personeelsbestand gaat niet meer samen met een slechte 'naam' van het bedrijf; het is geen indikatie meer van zwakke wervingskracht, zoals dat in 1964/65 het geval was. Daarentegen heeft leeftijd een sterke relatie gekregen met de arbeidsintensitelt van de organisatie (zie faktor IV, tabel 6.2).

Wat betreft de criteriumvaliditeit van de verklarende variabelen kan - op basis van de partiële korrelaties uit tabel 6.5 (p. 161) - nog vermeld worden dat de volgende vier variabelen op dit punt onder de mat blijuen:

- arbeidsintensiteit (2);

- onrust in het produktieproces (3);

- ontwikkeling personeelsfunktie (13);

- professionele personeelsbegeleiding (14).

Deze vier variabelen vertonen noch in 1964/65, noch in $1980 / 81$ enig substantieel verband met de drie verzuimmaten.

Welke kunnen nu de konklusies uit het bovenstaande zijn voor de vervolganalyse? De volgende beslissingen worden genomen. Zonder veel bezwaar kunnen allereerst de vier variabelen die in beide onderzoeken géén substantiële partiële relaties vertoonden met de drie verzuimmaten, voor de vervolganalyse geëlimineerd worden (variabelen 2, 3, 13, 14; twee van deze variabelen, namelijk 3 en 14 , bleken trouwens ook geen sterke inhoudsvaliditeit te hebben). Alternatieve operationaliseringen zullen voor drie van deze vier 
variabelen in de vervolganalyse gehanteerd worden.

De drie andere variabelen die instablele relatiepatronen vertoonden over beide onderzoekingen $(9,10,17)$ zullen in de vervolganalyse gehandhaafd blijven. Deze drie variabelen (platheidsgraad, bedrijfsgrootte en leeftijd) lijken te belangrijk om te snel te elimineren. Bovendien zijn het alle drie variabelen die gebaseerd zijn op 'harde" dokumentatiegegevens, waardoor onbetrouwbarheid niet de oorzaak kan zijn van mogelijke invaliditeit. Wel zal in de vervolganalyse voor variabele 9 (platheidsgraad) een alternatieve variabele gebruikt worden.

\subsection{Samenvatting van hoofdstuk 6}

In dit hoofdstuk werd verslag gedaan van een replikatie bij 85 middelgrote Nederlandse industriële bedrijven van een onderzoek dat Philipsen (1969) in de jaren 1964/65 uitvoerde bijj B3 eveneens middelgrote Nederlandse industriële ondernemingen. Het replikatie-onderzoek vond zestien jaar later - in 1980/81 - plaats. Beide onderzoeken werden uitgevoerd met behulp van dezelfde negentien verklarende variabelen, ongeveer dezelfde theoretische waarden binnen deze variabelen en dezelfde methode van materiaalverzamelen. Alleen de bedrijven waren in beide perioden niet dezelfde, hoewel het in beide onderzoeken wel ging om produktiebedrijuen van ongeveer gelijke grootte, uit ongeveer dezelfde bedrijfsgroepen en ongeveer gelijk verspreid over geheel Nederland. Uit de analyses bleek allereerst dat de variabelen in 1980/81 minder sterk onderling korreleerden - door de geringere spreiding waarschijnlijk - dan in 1964/65. Dus in 1980/81 'lijken' de bedrijven meer op elkar.

Door middel van faktoranalyse werden de negentien verklarende variabelen in vijf 'groepen' onderverdeeld. Aan vier hiervan kon in $1980 /$ Bl dezelfde benaming gegeven worden als in 1964/65. Deze faktoren waren:

- routisinering van het produktieproces;

- wervingskracht van de organisatie;

- korrelaten van verstedelijking;

- traditianele/moderne organisatie.

Vervolgens werden de relaties van de negentien verklarende varia- 
belen met de drie verzuimmaten geanalyseerd en vergeleken met de resultaten uit 1964/65.

De belangrijkste konklusie was dat 63 procent van de partiële relatieg met de frekwentie, 74 procent van de partiële relaties met de gemiddelde duur per geval, en 74 procent van de partiële relaties met het verzuimpercentage van zwak tot sterk bevestigd konden worden.

Op basis van beide onderzoekingen kon gekonkludeerd worden dat de volgende negen variabelen het verzuimpercentage in verhogende $z$ in beinvloeden:

- een geringe mate van routinisering;

- veel hinderlijke fysieke werkomstandigheden;

- geringe autonomie in de bedrijfsvoering;

- niet-uitgewerkte of platte organisatiestruktuur;

- autoritaire bedrijfsleiding;

- ongunstige uitkeringswoorwarden bij ziekte;

- sterke band met het GAK of de Bedrijfsvereniging;

- veel werknemers met korte diensttijden;

- hoge stedelijkheidsgraad van de omgeving.

Opnieuw op basis van beide onderzoekingen kon gesteld worden dat de volgende vijff variabelen géén verband met het verzuimpercentage vertonen:

- arbeldsintensiteit van de organisatie;

- onrust in het produktieproces;

- delegatie van bevoegdheden aan niet-leidinggevenden;

- ontwikkeling van de personeelsfunktie;

- professionele personeelsbegeleiding.

Bij de overblijuende vijf varlabelen verschillen de resultaten van beide onderzoeken signifikant van elkaar:

- het percentage ploegendienst-werknemers (hoewel de tendens positief is);

- scholingsgraad van het werk (de tendens is negatief);

- bedrijfsgrootte;

- slechte "naam" van het bedrijf (de tendens is positief);

- gemiddelde leeftijd produktiepersoneel.

Gelijksoortige konklusies werden opgesteld met betrekking tot de frekwentlie en de duur.

Bij de bespreking van de resultaten stonden de hypothesen en de 'theorie' van Philipsen centraal. De konklusies zijn hier als 
volgt samen te vatten:

- de resultaten van beide onderzoeken te zamen ondersteunen de 'verzuimtheorie" van Philipsen niet in alle details, maar wel in globale zin;

- in het algemeen blijkt de verzuimfrekwentie minder gevoelig en de verzuimduur juist meer gevoelig te zijn voor de verklarende variabelen dan verondersteld in de hypothesen;

- een aanvulling op de theorie lijkt dat de sociale en instrumentele binding aan de werksituatie niet alleen invloed heeft op de verzuimfrekwentie - zosls Philipsen meende - maar ook op de verzuimduur;

- de omvang en de aktiviteiten van de personeelsafdeling van een bedrijf lijkt veel minder beperkende invloed op het verzuim uit te oefenen dan bij de hypothesevorming gedacht was.

In de op één na laatste paragraaf van dit hoofdstuk werd tenslotte de validiteit van de verklerende variabelen besproken. 
7.1 De acht geëlimineerde en de dertien toegevoegde variabelen

De vervolganalyse wordt uitgevoerd met elf van de negentien in de replikatie-analyse gebruikte varlabelen, alsmede dertien toegevoegde variabelen. Kort kan nog herhaald worden (a) om welke redenen acht van de oorspronkelijke negentien verklarende variabelen geëlimineerd worden en (b) warom er dertien worden toegevoegd. Wat het eerste punt betreft, kan onderstaande tabel 7.1 duidelijkheid bieden.

Tabel 7.1 Da acht voor de vervolganalyse te elimineren vartabelen met de abnduiding van de reden

\begin{tabular}{|c|c|c|c|c|c|}
\hline $\begin{array}{l}\text { te ellimineren } \\
\text { variabelen }\end{array}$ & $\begin{array}{l}\text { geringe } \\
\text { spreiding }\end{array}$ & $\begin{array}{l}\text { geringe } \\
\text { Interne } \\
\text { konsis- } \\
\text { tentie }\end{array}$ & $\begin{array}{l}\text { geringe } \\
\text { vailiditeit/ } \\
\text { stabiliteit }\end{array}$ & $\begin{array}{l}\text { andere } \\
\text { readenen } \\
\text { (zle de } \\
\text { tekst) }\end{array}$ & $\begin{array}{l}\text { vervangen } \\
\text { door } \\
\text { variabele }\end{array}$ \\
\hline $\begin{array}{l}\text { 1. produktieproces } \\
2 \text { mrbeldsintensitelt } \\
3 \text { onrust produktieproces } \\
9 \text { organisat lestruktuur } \\
13 \text { personeelsfunktie } \\
14 \text { personeelsbegeleiding } \\
15 \text { uitker ingsvoorwarden } \\
18 \text { diensttijd }\end{array}$ & $\begin{array}{l}x \\
x \\
x \\
x\end{array}$ & $\begin{array}{l}x \\
x\end{array}$ & $\begin{array}{l}x \\
x \\
x \\
x \\
x\end{array}$ & $\begin{array}{l}x \\
x\end{array}$ & $\begin{array}{c}20 \text { en } 21 \\
20 \\
22 \\
23 \\
24\end{array}$ \\
\hline
\end{tabular}

Zoals reeds in paragraef 5.3 werd vermeld, bezitten de variabelen $3,13,14$ en 15 een geringe spreiding en/of een geringe interne konsistentie, waardoor ze niet optimaal brulkbaar zijn in onderzoek met korrelatierekening en daerop gebaseerde analysetechnieken. Voorts werd in paragraaf 6.6 beargumenteerd dat de nummers $2,3,9,13$ en 14 geen voorspellende waarde vertoonden ten aanzien van de verzuimmaten en/of weinig stabiliteit vertoonden over de beide onderzoeken. Om deze redenen zijn ze weinig bruikbaar voor de vervolganalyse.

De variabelen $1,3,9,13$ en $14 \mathrm{zijn}$ in de vervolganalyse door de nummers 20 tot en met 24 vervangen. Argumentatie hiervoor treft 
men aan in hoofdstuk 5 bij hun beschrijuing. Voor arbeidsintensiteit (2), uitkeringsvoorwaarden (15) en dlensttijd (18) zijn geen vervangende variabelen beschikbaar.

De argumentatie voor de eliminatie van variabele 18 (percentage produktiewerknemers, korter dan 1 jaar in dienst) kan kort zijn. Om analytische redenen diende het aantal variabelen in de vervolganalyse namelijk zo beperkt mogelijk gehouden te worden. Diensttijd is dearom ook nog uitgesloten, omdat deze in 1980/81 geen verband vertoont met de verzuimmaten (partiële korrelaties van respektievelijk .03, .06 en .12, zie tabel 6.5, p. 161). Verder onderzoek met deze variabele is dan ook minder zinvol.

De vervolganalyse nu wordt, behalve met de elf oorspronkelijke en vijf vervangende, met acht 'nieuwe' variabelen uitgevoerd. Waarom juist deze acht werden opgenomen, werd reeds in paragraaf 5.1 beargumenteerd. Kort herhaald komt het erop neer, dat de variabelen 25 tot en met 27 (financieel-ekonomische positie, werkloosheidspercentage van de omgeving en snelheid van de verzuimkontrole) voornamelijk ingevoerd zijn om het begrip verzuingelegenheid te representeren.

De nummers 28 en 29 (aantal kontakten tussen funktionarissen over zieke werknemers en het percentage buitenlandse produktiewerknemers) zijn voornamelijk opgenomen om respektievelijk aandacht woor het individuele ziektegeval en de afwezigheidsnoodzaak te indiceren.

Verder zijn de variabelen 30 tot en met 32 (sociaal en instrumenteel leiderschap en invloedsverschillen tussen produktieleiding en uitvoerenden) erbij betrokken om de sociale en instrumentele binding aan de werksituatie te vertegenwoordigen.

De struktuur van dit hoofdstuk is tenslotte als volgt. In paragraaf 7.2 worden de relaties tussen de 24 verklarende variabelen weergegeven door middel van een korrelatie-matrix en een darrop gebaseerde faktoranalyse. De zeven gevonden faktoren worden in paragraaf 7.3 besproken vanuit organisatie-sociologisch perspektief. Het verzuim komt in paragraaf 7.4 aan de orde. Deze paragraaf geeft een overzicht van de relaties van de 24 verklarende variabelen met de drie verzuimmaten. Nulde-orde, partiële en multipele relaties zullen vermeld worden. In paragraaf 7.5 worden de opgestelde hypothesen met betrekking tot het verzuim getoetst. 
Verschil zal darbij gemaakt worden tussen de invloeden op de frekwentie, en op de duur. Vanwege de overzichtelijkheid zal in paragraaf 7.6 een integratie van de gevonden resultaten nagestreefd worden. Dit geschiedt door de relaties tussen de zeven gevonden faktoren uit de faktoranalyse en de drie verzuimmaten nader te beschouwen. In paragraaf 7.7 worden voor de vier belangrijkste van de zeven faktoren kausale modellen opgesteld die met. behulp van de statistische techniek LISREL getoetst zullen worden op hun juistheid. Het voordeel van deze aanpak is dat er meer inzicht door kan ontstaan in het proces dat tat verzuim leidt. Een samenvatting van dit over de vervolganalyse handelende hoofdstuk wordt in de laatste paragraaf (7.8) gegeven.

Voor de overzichtelijkheid volgen hieronder nu de 24 verklerende variabelen die in dit hoofdstuk gebruikt zullen worden.
4 percentage produktiewerknemers in ploegendienst
5 hinderlijke fysieke werkomstandigheden
6 scholingsgraad produktiewerk
7 delegatie aan niet-leidinggevenden
8 autonomie in de bedrijfsvoering
10 bedrijfsgrootte
11 bedrijf autoritair geleid
12 slechte 'naam' van het bedrijf (arbeidsmarkt-positie)
16 sterke band met GAK/Bedrijfsvereniging
17 gemiddelde leeftijd produktiepersoneel
19 stedelijkheidsgraad gewest warin bedrijf $1 \mathrm{igt}$

20 onrust in het produktieproces (nieuwe versie)

21. vrijheid in de takuitvoering in de produktie

22 grootte van de groepen in de produktie

23 relatieve grootte personeelsafdeling

24 tijd besteed an personeelsbegeleiding en -zorg

25 slechte financieel-ekonomische positie bedrijf

26 werkloosheidspercentage rayon warin bedrijf ligt

27 snelheid van de verzuimkontrole

28 aental kontakten over zieke werknemers

29 percentage buitenlandse produktiewerknemers

30 sociaal leiderschap

31 instrumenteel leiderschap

32 invloedsverschil leiding - uitvoerenden 


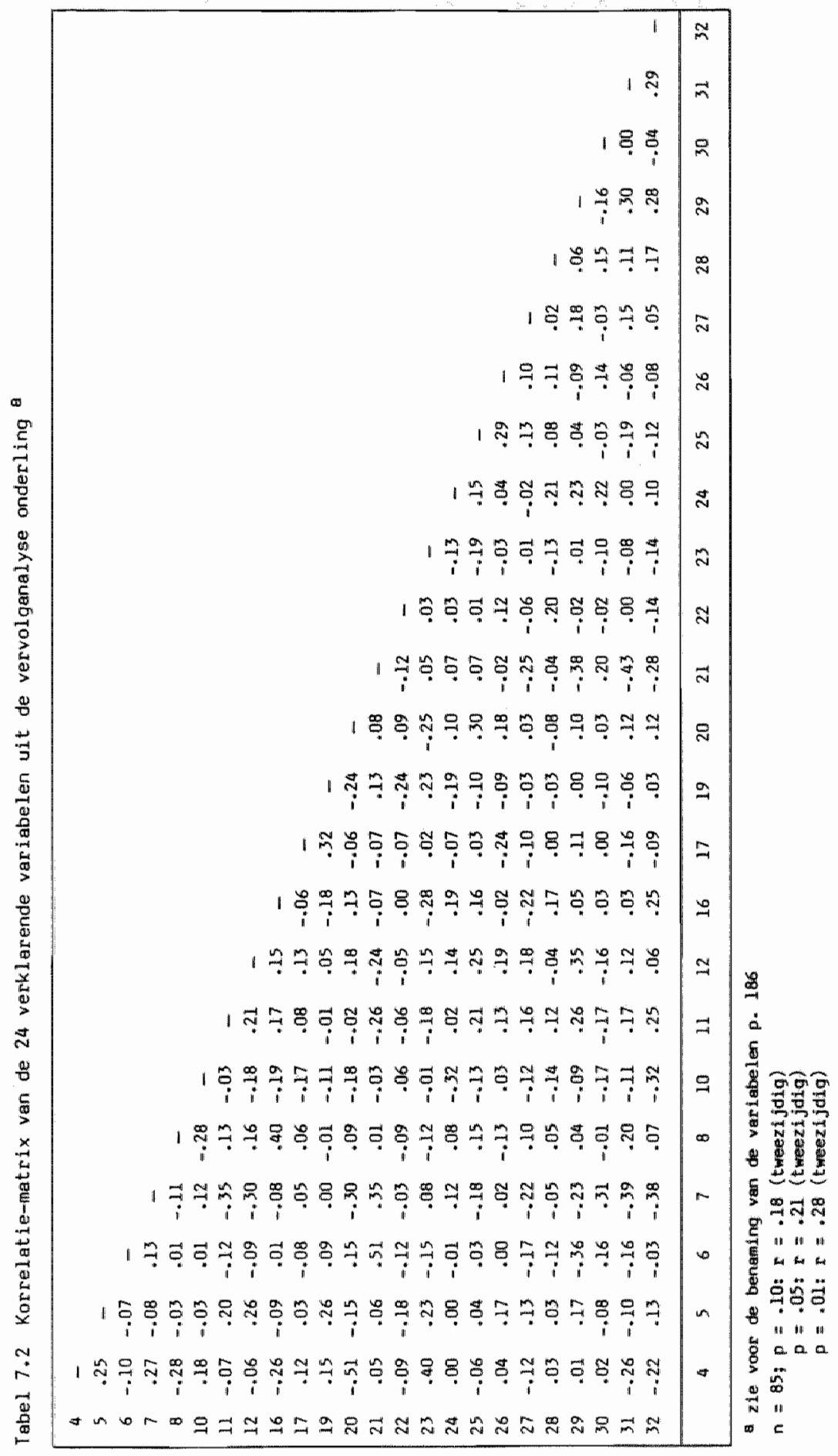


Tabel 7.2 op de vorige pagina geeft de korrelaties weer tussen de 24 verklarende variabelen in de vervolganalyse. Slechts vijf korrelaties blijken groter dan of gelijk aan .40 , hetgeen erop duidt dat er welnig 'overlappende" variabelen nast elkaar voorkomen in de analyse. Dit betekent ook dat er voor de uit te voeren regresaie-analyse geen gevar bestaat voor zogenaamde multi-collineariteit (Gordon, 1968).

Tabel 7.3 geeft de resultaten weer van de faktoranalyse van de 24 verklarende variabelen, na rotatie. De bepaling van het aantal te roteren faktoren kan op statistische en inhoudelijke criteria geschieden (Brand-Koolen, 1972, p. 217-222). Op inhoudelijke gronden is voor een zevental faktoren gekozen. Op statistische gronden is dit ook acceptabel omdat in deze analyse bij zeven faktoren namelijk een thèta-waarde van ongeveer 1 verkregen wordt. De zeven faktoren zijn als volgt benoemd (zie tabel 7.3):

\section{Kwaliteit van het werk en de menselijke verhoudingen} met, in volgorde van belang: vrijheid in de taakuitvoering, gering percentage buitenlandse werknemers, hoog geschoold werk, weinig instrumenteel leiderschap, veel delegatie van verantwoordelijkheden, weinig invloedsverschillen, een goede 'neam' van het bedrijf, demokratische bedrijfsleiding, geen snelle verzuimkontrole en veel sociaal leiderschap.

\section{Automatiseringagraad van het produktieproces}

met: rust in het produktieproces, veel ploegendienst, veel delegatie van verantwoordelijkheden, grotere bedrijfsomvang, weinig instrumenteel leiderschap en ook een lets lagere schollingsgraed van het werk.

\section{Korrelaten van verstedelijking}

met: hoge stedelijkheidsgraad, hinderlijke fysieke werkomstandigheden, kleine groepsgrootte in de produktie, grote inwloedsverschillen en kleine bedrijfsomvang. 
met: slechte financieel-ekonomische positie, hoog werkloosheidspercentage van het rayon waarin het bedrijf ligt, een slechte 'naam' van het bedrijf, hinderlijke fysieke werkomstandigheden, autoritaire bedrijfsleiding, weinig instrumenteel leiderschap en onrustig produktieproces.

\section{Aandacht voor de individuele werknemer}

met: veel tijd besteed aan personeelsbegeleiding en -zorg, kleine bedrijfsomvang, grote mate van sociaal leiderschap, veel kontakten over zieke werknemers en veel delegatie van verantwoordelijkheid.

\section{Gemiddelde leeftijd van het personeelsbestand}

met: hoge gemiddelde leeftijd van het personeelsbestand, laag werkloosheidspercentage van het rayon warin het bedrijf ligt en hoge stedelijkheidsgraad van het gewest warin het bedrijf ligt.

\section{Traditionele/moderne orgenisatie}

met voor de moderne organisatiewijze: zwakke band met het GAK of de Bedrijfsvereniging (dus veel eigenrisikodracht), relatief grote personeelsafdeling, weinig autonomie in de bedrijfsvoering, bedrijf demokratisch geleid, kleine invloedsverschillen, veel ploegendienst en weinig kontakten over zieke werknemers.

In vergelijking met de faktoranalyse die op de negentien replikatievariabelen werd uitgevoerd (tabel 6.2, p. 153), kunnen de volgende verschillen opgemaakt worden.

De oorspronkelijke faktor routinisering heeft thans een splitsing ondergaan door onder meer de invoering van de variabelen 20 (onrust), 21 (vrijheid), 29 (buitenlandse werknemers) en 31 (instrumenteel leiderschap). De afgesplitste faktor is kwaliteit van het werk en de menselijke verhoudingen (I). De "overgebleven' faktor is outomatiseringsgraad van het produktieproces (II) genoemd. Deze afsplitsing toont aan dat de opdeling van de oorspronkelijke variabele 1 (routisinering) een goede ingreep in geweest. De nieuwe variabele rust/onrust (20) blijkt namelijk thans de belangrijkste te zijn in de faktor automatiseringsgraad, terwijl de 
Tabel 7.3 Requltiten wan de faktoranelyse na rotatle (Jöreskog-methode van faktorisering; varimax-rotatle); variabelen uit de verwolganalyse $(n=85)$ a

\begin{tabular}{|c|c|c|}
\hline de verklarende varlabelen & $\begin{array}{l}\text { I } \\
\text { kwall telt } \\
\text { wan het } \\
\text { werk an de } \\
\text { mensell jke } \\
\text { verhoud Ingen }\end{array}$ & $\begin{array}{l}\text { II } \\
\text { gutomati- } \\
\text { serings- } \\
\text { graad } \\
\text { van het } \\
\text { produkt le- } \\
\text { proces }\end{array}$ \\
\hline 4. percentage produkt lewerknemers in ploegendlenst & - & .66 \\
\hline 5. hinderli jke fysieke werkomstandigheden & - & - \\
\hline 6. gchol Ingagraad produkt iewerk & .56 & -.25 \\
\hline 7 delegatie aan niet-leidinggevenden & .50 & .37 \\
\hline 8 eutonomile in de bedrijfavoering & - & - \\
\hline 10 bedrijfagrootte & - & .28 \\
\hline 11 bedrijf autoritair geleld & -.35 & - \\
\hline 12 sllechte 'namin' wan thet bedrijf & -38 & - \\
\hline 16 sterke band met GAK/Bedrijfavereniging & - & - \\
\hline 17 gemiddelde leeft 1 jd produkt iepersoneel & - & - \\
\hline 19 stedelijkheidagraad gewest war in bedrijf ligt & - & - \\
\hline 20 onrust in thet produktieproces (nieuwe versie) & ---- & ------- \\
\hline 21 vrijheld in de takultvoering in de produktie & .75 & - \\
\hline 22 grootte van de groepen in de produktle & - & - \\
\hline 23 relatieve grootte personeelsafdeling & - & - \\
\hline $24 \mathrm{t} l \mathrm{jd}$ besteed an personeelsbegelelding en -zorg & - & - \\
\hline 25 slechte financleel-ekonomische positie bedrljf & - & - \\
\hline 26 werkloosheidspercentage rayon warar in bedrijf ligt & - & - \\
\hline 27 sinellheld van de verzulimkontrole &.- .35 & - \\
\hline 28 antal kontakten over zleke werknemers & - & - \\
\hline 29 percentage bultenlandse produkt lewerknemers & -.60 & $=$ \\
\hline 30 socieal Jeiderachap & .25 & - \\
\hline 31 instrumenteel lelderschap & -.54 & -.27 \\
\hline 32 Invloudsverschll leiding - uitvoerenden & -.39 & - \\
\hline percentage gebonden variantie per faktor & 10.2 & 6.5 \\
\hline
\end{tabular}

Q alleen ladingen $\geqslant .25 \mathrm{z} 1 \mathrm{j}$ in vermeld 


\begin{tabular}{|c|c|c|c|c|c|c|}
\hline $\begin{array}{c}\text { III } \\
\text { korrelatem } \\
\text { wan } \\
\text { verstedle- } \\
\text { IIjlkinig }\end{array}$ & $\begin{array}{c}\text { IV } \\
\text { alechte } \\
\text { financieel/ } \\
\text { ekonomische } \\
\text { positie } \\
\text { van het. } \\
\text { bedrijf }\end{array}$ & $\begin{array}{l}\text { aandacht } \\
\text { voor de } \\
\text { individuele } \\
\text { werknemer }\end{array}$ & $\begin{array}{c}\text { VI } \\
\text { gemiddelde } \\
\text { leeftijd } \\
\text { van het } \\
\text { personeels- } \\
\text { bestand }\end{array}$ & $\begin{array}{l}\text { VII } \\
\text { traditionele/ } \\
\text { moderne } \\
\text { orgenlsetle }\end{array}$ & \multicolumn{2}{|l|}{$\begin{array}{l}\text { percentage } \\
\text { gebonden } \\
\text { variantie } \\
\text { per } \\
\text { variabele }\end{array}$} \\
\hline- & - & - & - & .31 & 55.9 & 4 \\
\hline .49 & .29 & - & - & - & 40.7 & 5 \\
\hline- & - & - & - & - & 43.9 & 6 \\
\hline- & - & .26 & - & - & 54.7 & 7 \\
\hline- & - & - & - & -.39 & 24.4 & 8 \\
\hline-.26 & - & -.48 & - & - & 45.0 & 10 \\
\hline- & .26 & - & - & -.36 & 38.8 & 11 \\
\hline- & .47 & - & - & - & 44.6 & 12 \\
\hline- & - & - & - & -.65 & 45.9 & 16 \\
\hline- & - & - & .61 & - & 39.7 & 17 \\
\hline .53 & - & - & .26 & - & 40.1 & 19 \\
\hline---- & $---\cdots$ & $\ldots-\cdots$ & ------ & $-----\cdots$ & $---\cdots$ & - - \\
\hline - & .26 & - & - & - & 57.4 & 20 \\
\hline- & - & - & - & - & 63.6 & 21 \\
\hline-.42 & - & - & - & - & 18.6 & 22 \\
\hline- & - & - & - & .50 & 37.1 & 23 \\
\hline - & - & .59 & - & - & 39.4 & 24 \\
\hline - & .63 & - & - & - & 45.9 & 25 \\
\hline- & .49 & - & -38 & - & 4.1 .3 & 26 \\
\hline- & - & - & - & - & 21.4 & 27 \\
\hline- & - & .29 & - & -.25 & 20.8 & 28 \\
\hline- & - & - & - & - & 42.6 & 29 \\
\hline- & - & .46 & - & - & 30.0 & 30 \\
\hline- & -.26 & - & - & - & 47.3 & 31 \\
\hline .35 & - & - & - & -.33 & 51.7 & 32 \\
\hline 5.0 & 5.4 & 4.6 & 3.7 & 5.9 & $41 * 3$ & \\
\hline
\end{tabular}


nleuwe variabele vrijheid (21) het centrale punt is geworden van de faktor kwaliteit van het werk en de menselijke verhoudingen (faktor I).

De oorspronkelijke faktor korrelaten van verstedelijking is in de nieume faktoranalyse ook weer terug te vinden (faktor III). Op deze faktor scoort ook de struktuur-variabele 22 (groepsgrootte), zoals ook de struktuur-variabele 9 (platheidsgraad) op de oorspronkelijke faktor verstedelijking scoorde.

De faktoren IV en $V$ (respektievelijk slechte financieel-ekonomische positie en andacht voor de individuele werknemer) zijn nieuwe faktoren door de introduktie van nieuwe variabelen. Hierbij valt te zien dat de oorspronkelijke faktor wervingskracht van de organisatie thans opgedeeld is over de nieuwe faktor I (kwaliteit van het werk en de menselijke verhoudingen) en de nieuwe faktor IV (financieel-ekonomische positie), hetgeen op zichzelf een plausibele verandering $1 \mathrm{ijkt}$.

Faktor VI, gemiddelde leeftijd van het personeelsbestand, lijkt op de oorspronkelijke faktor leeftijd.

Tenslotte is daar faktor VII, traditionele respektievelijk moderne organisatiewijze, welke op de 'oude' faktor met dezelf de naam lijkt. Centraal in de moderne organisatie blijven de variabelen lage graad van autonomie, zwakke band met het GAK of de bedrijfsvereniging, ploegendienst, grate/ontwikkelde personeelsafdeling/ -funktie.

7.3 Organisatie-sociologische bespreking van de zeven gevonden faktoren

De resultaten van de faktoranalyse zullen thans, tegen de achtergrond van eerdere organisatie-sociologische onderzoeken en theorieën besproken worden.

Hierbij kan er vooraf aan herinnerd worden dat resultaten van faktoranalyses in het algemeen met voorzichtigheid beoordeeld moeten worden. Het aantal faktoren warover geroteerd wordt is bijvoorbeeld deels op statistische en deels op theoretisch/inhoudelijke gronden gekozen. Niet elke auteur behoeft dan ook precies dezelfde oplossing te kiezen. Bovendien kan toevoeging of eliminatie van een paar "centrale" variabelen, die sterk samenhangen met andere variabelen, de faktorstruktuur als geheel doen wijzigen. 
Ten eerste zullen de faktoren I en II in samenhang met elkar besproken worden.

Faktor I betreft de kwaliteit van het werk en de menselijke verhoudingen. Hierop komen zelfs tien variabelen terecht met een lading van . 25 of meer (een lading van $.25 \mathrm{kan}$ ongeveer als een signifikante lading gezien worden, hetgeen betekent dat deze variabele signifikent korreleert met de betreffende faktor). Uit deze faktor valt te konkluderen dat hoog geschoold werk en een grote mate van vrijheid in werktempo en werkanderbrekingen samengaat met algemeen als positief bestempelde menselijke verhoudingen (delegatie, demokratische leiding, social-gericht leiderschap, weinig invloedswerschillen, en dergelijke). Hier zien we dus een samengaan van bepaalde inhoudelijke kenmerken van het werk met bepaalde "geinstitutionaliseerde betrekkingen on verhoudingen tussen organisatieleden", zoals Lammers (1983, p. 435) de organisatiestruktuur definieerde.

Op faktor II, autonatiseringsgraad van het produktieproces, laden óók, hoiewel zwak, struktuur-variabelen, namelijk bedrijfsgrootte, delegatie en instrumenteel leiderschap. Geautomatiseerde produktieprocessen spelen zich dus iets meer af in grotere bedrijven en deze processen gaan samen met relatief meer delegatie van verantwoordelijkheden en relatief weinig instrumenteel leiderschap. In felte omvatten dus zowel faktor I als faktor II zowel technologische (produktieproces-) kenmerken als organisatiestrukturele kenmerken. Bij faktor I ligt het aksent echter op de kwaliteit van het werk en de daarvoor benodigde opleiding en bij faktor II ligt het aksent op de organisatie van het produktieproces (al dan niet storingsvijj/rustig, en al dan niet in ploegendienst geargamiseerd). Hoewel we hier geen kausale relaties kunnen aantonen, zouden beide faktoren een andersteuning kunnen zijn voor het idee van het zogenaande 'technologisch imperatief van de organisatiestruktuur" (Hickson et al., 1969, p. 379).

Deze gedachte verdient verdere toelichting. In de organisatiesociologie bestond de laatste twee decennia veel aendacht voor de relatie tussen de technologie (het produktieproces) en de struktuur van organisaties. Het werk van een viertal auteurs (groepen), die het denken over deze materie sterk bepaald hebben, zal daarom kort behandeld worden.

Ter inleiding daarop kan herhaald worden dat onder organisatiestruktuur verstaan wordt "de min of meer geinstitutionaliseerde 
betrekkingen en verhoudingen - zowel de formele als de informele - tussen bekleders van organisatorische posities" (Lammers, 1983, p. 435). Hieronder vallen dus delegatie van verantwoordelijkheid, vormen van leiderschap en de wijze van personeelsbegeleiding, maar ook bedrijfsgrootte, groepsgrootte of platheidsgraad van de organisatie en de grootte van de personeelsafdeling als meer formele uitingen van de bedoelde betrekkingen en verhoudingen. Woodward $(1958,1965)$ is de eerste die de technologie als determinant van de organisatievorm aan de orde stelde. Zij onderscheidde drie soorten technologie: enkelstuks- en kleine serieproduktie, grote serie- en massaproduktie en tenslotte procesproduktie. Op basis van gegevens van zo"n honderd Engelse bedrijven toont zij an dat deze drie typen produktieprocessen wat organisatiestruktuur betreft - aantal nivo's, spans of control, arbeidskosten, formalisatiegraad, stafgrootte, menselijke relaties - sterk verschillen. Enkelstuks- en procesproduktie vertonen echter wel een aantal overeenkomsten en steken wat 'industrial and human relations' betreft gunstig of tegen grote serie- en massaproduktie. Woodward vindt dus als het ware een kromlijnig verband tussen de drie technologie-typen en de kwaliteit van de menselijke relaties in een organisatie (een U-relatie dus).

Perrow (1967, p. 194-195) verstond onder technologie "the work done on raw materials" of wel het toepassen van technieken om grondstoffen om te zetten in eindprodukten. In zijin theoretische opzet ging hij ervan uit dat de technologie van een organisatie de routinematigheid voornamelijk - de struktuur van die organisatie, in de zin van beslissingsvrijheid, invloed en wijze van koordinatie, bepaalt. Empirisch onderzoek (zie de goede samenvatting van Fry, 1982) heeft inderdaad laten zien dat de invloed van routinematig werk op centralisatie en formalisatie zeer sterk is. Ten derde zijn de studies van de medewerkers van de Aston-universiteit in Birmingham/Engeland in dit kader van belang. Hun technologie-index was 'workflow-integration', met aan de 'hoge kant" sterk geïntegreerde, geautomatiseerde en rigide technologieën en aan de 'lage kant' niet-geautomatiseerde, flexibele produktieprocessen (Pugh et al., 1969). Over het algemeen blijkt uit het Aston-onderzoek dat de technologie van een organisatie positief samenhangt met funktie- en rol-specialisatie en organisatiegrootte, maar nlet met centralisatie (Payne \& Pugh, 1976, p. 1135). Ten vierde en tenslotte dient vermeld te worden dat onderzoekin- 
gen uit de meer psychologische hoek keer op keer aangetoond hebben dat taakkenmerken duidelijke verbanden vertonen met de betrekkingen en verhoudingen tussen de orgenisatieleden. Men denke hierbij aan het 'job-design-onderzoek' en het onderzoek rond het Job Characteristics Model van Hackman en 01dham (1976).

In deze onderzoeksliteratuur ziet men dat zowel technologie als organisatiestruktuur zeer globale begrippen zijn, die door een tamelijk grote verscheidenheid van konkrete variabelen gerepresenteerd kunnen worden. Onder technologie vallen bijvoorbeeld kenmerken van het produktieproces, maar ook van taakinhouden (zie ook Gerwin, 1981). En onder de struktuur vallen zowel orgenisatievorm-kenmerken als aspekten van menselijke relaties. Beide begrippen zijn dus vaag omlijind en het lijkt dan ook niet verwonderlijk dat het afhangt van het eantal en de soort gehanteerde operationalisaties of men al dan niet steun vindt voor het idee van het 'technologisch imperatief' van de organisatiestruktuur (zie Fry, 1982, voor een overzicht).

Zo is het ook in de resultaten van de hier te bespreken analyse. Zowel in faktor I als II komen variabelen voor die zowel de technologie als de organisatiestruktuur geacht worden te beschrijven. Men zou dus kunnen konkluderen dat er een zekere samenhang is tussen technologie en struktuur. Maar de vraag is of dit nu pleit voor het 'technologisch imperatief'. Beter is warschijnlijk om alleen te konkluderen dat sommige technologie- en/of takkkenmerken met sommige struktuurkenmerken samengaan in dit anderzoek. Hoe problematisch een en ander is, blijkt ook uit het feit dat de faktoranalyse laat zien dat organisatiestruktuur-varlabelen als organisatievorm (groepsgrootte), centralisatie (delegatie en wijze van leidinggeven) en organisatiegrootte op drie verschillende faktoren laden, hetgeen wil zeggen dat deze struktuurkenmerken ook onderling weinig of geen verband vertonen.

Bovendien kan eraan herinnerd worden dat in de replikatie-analyge met de negentien variabelen (zie tabel 6.2, p. 153) de vijf technologie-variabelen samen op één faktor scoorden en de struktuurvariabelen op meerdere andere faktoren. Dáár zou de konklusie dus zijn geweest dat er geen verband is tussen technologie en struktuur. Dit was ook de konklusie die Lammers (1983, p. 160-165) trok bij de bespreking van het onderzoek van Philipsen (1969). Het lijkt, konkluderend, goed om af te stappen van het hanteren van zeer breed gedefinieerde koncepten als technologie en organi- 
satiestruktuur, en het zoeken naer verbanden tussen beide. Wel zou men kunnen zorken naar de samenhang tussen bepaalde technologie-kenmerken en bepalde organisatiestrukturele kenmerken.

Faktor III, korrelaten van verstedelijking, is geen erg stabiele faktor. In de nieuwe faktoranalyse blijkt, in vergelijking tot $1964 / 65$, alleen variabele 9 (platheidsgraad), door middel van variabele 22 (groepsgrootte) gehandhaafd te blijven, samen met variabele 19 (stedelijkheidsgread). De relatie stedelijkheid - organisatiestruktuur is dus blijkbaar wel duurzaam.

Philipsen (1969) veronderstelde dat een uitgewerkte orgenisatiestruktuur, steil in plaats van plat, een teken was van de hoog ontwikkelde industrie, die meer in stedelijke dan in plattelandsgebieden voorkwam.

Men zou uit de resultaten ook kunnen konkluderen dat de vorm van de organisatie (plat of steil.) lets is dat kultureel bepaald wordt. In stedelijke gebieden neigen de bedrijven meer naar een steile vorm (kleine groepen) en in agrarische gebieden meer naar een platte vorm, omdat in stedelijke gebieden bedrijven meer te maken hebben met een meer marktgericht, 'cosmopolitan' personeelsbestand met een moderner beroepsbeeld. Steilheld en uitgewerktheid van de organisatie zou dus een tegemoetkoming kunnen zijn aan de wensen van het personeel voor betere werkrelaties en/ of het gevolg zijn van de denkbeelden van de leiding van stedelijke bedrijven.

Bij zijn behandeling van het inmiddels vrij grote aantal internationale vergelijkende organisatiestudies wijst Lammers (1983) op het maatschappij- of kultuurgebonden karakter van organisaties. De studie van Philipsen (1969), alsmede de resultaten van dit onderzoek laten echter zien dat het kultuurgebonden karakter van organisaties in zekere zin ook reeds binnen één land te ontwaren valt door te letten op verschillen tussen bedrijven in stedelijke en $\mathrm{pl}$ attelandsgebieden.

Dok zou het mogelijk zijn de relatie tussen stedelijke omgeving en organisatie-uitgewerktheid op een niet-kulturele wijze te interpreteren. Als men ervan uitgaat dat in stedelijke gebieden de organisatieomgeving 'complexer' is - in de zin van bijvoorbeeld de arbeldsmarkt, maar ook in de zin van technologische, ecologische, wettelijke kondities - en men weet dat omgevingscomplexiteit over het algemeen ( $\mathrm{Hall}, 1982$, p. 86) samenhangt met organi- 
satiecomplexiteit, dan is het plauslbel dat in stedelijke gebieden organisaties steller/uitgewerkter zijn, met kleinere werkgroepen, dan in niet-stedelijke gebieden.

Tenslotte kan in dit verband nog opgemerkt worden dat Blau en Schoenherr (1971) konstateerden dat steile organisaties (met veel nivo's en kleine werkgroepen dus) een tendens vertoonden tot meer decentralisatie en delegatie van verantwoordelijkheden. Philipsen (1969) vond ook dat dit soort organisaties veel delegatie en demokratisch leiderschap kende. In dit replikatie-onderzoek kan dat echter niet bevestigd worden, zoals faktor III laat zien: de organisatievorm, hier in de zin ven groepsgrootte, blijkt namelijk niets meer te maken te hebben met de vertikale relaties tussen de organisatie-genoten in termen van delegatie, leiderschapspatronen en invloedsverschillen.

Faktor IV, financieel-ekonomische positie van het bedrijf is organisatie-sociologisch eveneens van belang. In de zogenaamde kontingentie-theorieën houdt men zich bezig met (a) de invloed van onzekere, onvoorspelbare situationele faktoren, als de omgeving op de organisatiestruktuur, en (b) de aanpassing van de organisatiestruktuur aan de situationele faktoren opdat de organisatie effektief en/of efficiënt blijft funktioneren.

Pfeffer en Leblebici (1973), Payne en Pugh (1976) en Pennings en Tripathi (1978) vonden dat een grote mate van afhankelijkheid van de omgeving en van omgevingsdreiging samengaat met een hoge graad van centralisatie en formalisatie (ongeacht wel of niet effektief funktioneren). Daarentegen konkludeert Khandwalla (1981) op basis van eigen onderzoek in een groot aantal Amerikaanse en Canadese bedrijven, dat organisaties onder druk meer organisch, participatief zijin.

Wat blijkt nu uit het onderhavige onderzoek? Faktor IV laat zien dat ekonomische dreiging (hoog werkloosheidspercentage in de omgeving en een slechte eigen financieel-ekonomische positie) enigszins samengaat met een grotere mate van autoritair leiderschap en een geringere mate van instrumenteel leiderschap. Dreilging lijkt dus tot "centralisatie' te leiden. Meteen moet echter opgemerkt worden dat deze vormen van leiderschap ook als oorzaak bezien kunnen worden van de ekonomische situatie waerin het bedrijf verkeert.

Het $\mathbb{l i j k t}$ zelfs plausibeler te veronderstellen dat een geringe 
mate van instrumenteel (produktie-gericht) leiderschap mede oorzaak is van een slechte financleel-ekonomische positie van het bedrijf. Indien het laatste julst zou zijn - hetgeen met transversaal onderzoek niet aan te tonen valt - dan hebben we hier minder te maken met een kontingentievraagstuk en meer met een leiderschapsvraagstuk (hierop wordt in paragraaf 7.7 met behulp van een 'kausaliteitsanalyse' teruggekomen).

Faktor $V$, aandacht voor de individuele werknemer, ondersteunt tot op zekere hoogte de door vele auteurs ontwikkelde stelling (onder anderen Acton Society Trust, 1953, 1957; Revans, 1958; Indik, 1965; Inghem, 1970) dat grote bedrijven gekenmerkt worden door minder persoonlijke relaties en kommunikatie. Faktor $V$ laat namelijk zien dat er in grotere bedrijven minder tijd besteed wordt aan personeelsbegeleiding en -zorg, en dat sociaal leiderschap en delegatie van verantwoordelijkheid er minder sterk ontwikkeld zijn.

Dat de nieuw gevormde variabele 24 (personeelsbegeleiding/-zorg) hoog laadt op deze faktor $V$ kan averigens als ondersteuning gezien worden van de validiteit van deze variabele.

Faktor VI, gemiddelde leeftijd van het personeelsbestand, bevat drie variabelen warvan de gemiddelde leeftijd van het produktiepersoneel en het werkloosheidspercentage van het rayon warin het bedrijf ligt de belangrijkste zijn.

Dat een relatief jong personeelsbestand samengaat met een relatief hoog werkloosheidspercentage in het rayon waarin het bedrijf ligt, heeft mogelijk als achtergiond dat - indien de werkloosheid hoog is - bedrijven geneigd zullen zijn op de arbeidsmarkt, uit oogpunt van gezondheid minder risicovol (en dus jong) personeel te rekruteren. Mogelijk is ook, dat oudere personeelsleden bij een slechte konjunktuur per saldo meer afvloeien dan jongere.

Faktor VII is traditionele respektievelijk moderne organisatie (wijze) genoemd. Dit heeft met name betrekking op het personeelsbeleid en het beleid ten aanzien van zieken en ziekteverzuim.

De 'moderne' bedrijven zijn voornamelijk niet-autonome concernonderdelen met een grote personeelsafdeling die zelf de administratie en kontrole voor de Ziektewet uitvoert. In dit soort be- 
drijven wordt relatief veel in ploegendienst gewerkt. Ze worden tevens demokratisch geleid met kleine invloedsverschillen tussen leiding en uitvoerenden. Dok zijn er in deze "moderne' bedrijven relatief weinig kontakten tussen personeelsafdeling en bedrijfsleiding over zieke werknemers. Dit leatste zou begrepen kunnen worden, indien moderne bedrijven ook minder verzuim hebben (hetgeen inderdaad aangetoond zal worden), waardoor er ook minder noodzak tot overleg over zieken bestaat.

Interessant zijn de overeenkomsten van dit onderzoek met het door Lammers (1983, p. 157-160) besproken onderzoek van Gater et al. (1966). Deze auteurs onderzochten 47 Engelse bedrijven met goede en slechte toekomstperspektieven. De goede bleken een meer aktieve bedrijfsvoering te vertonen en de slechte een meer passieve. De aktieve ofwel modern genoemde bedrijfsvoering wordt onder meer gekenmerkt door relatief veel delegatie, informatie-uitwisseling, lange termijnplanning, marktonderzoek en analyse van onder andere verloop- en verzuimgegevens. De passieve of traditionele bedrijven vertoonden deze karakteristieken niet of in veel mindere mate.

Moderne organisaties (organische zowel als mechanische) zijn volgens Lammers (1983, p. 368) geformaliseerder, funktioneel gespecialiseerder en horizontaal gedifferentieerder dan traditionele organisaties. Bovendien zouden maderne organisaties meer burokratische discipline kennen dan traditionele organisaties. Deze verschillen tussen moderne en traditionele organisaties zijn maar ten dele terug te vinden in de hier gevonden faktor VII; men zie bijvoorbeeld de grotere specialisatie/differentiatie (grotere personeelsafdelingen!) var de moderne organisaties. Faktor VII toont echter ook een centralisatie-decentralisatie dimensie die meer op het mechanisch-organische onderscheid (Burns \& Stalker, 1961) zou duiden en minder op het traditioneel-moderne onderscheid in de termen van Lammers. Met andere woorden, volgens de criteria van Lammers zou faktor VII ook een mechanisch-organische dimensie bezitten.

De hier behandelde zeven faktoren zullen in de paragrafen 7.6 en 7.7 nog terug komen. Nadat namelijk de relatie van de 24 verklarende variabelen met de drie verzuimmaten is gerapporteerd, zal ook nog aandacht geschonken worden aan de relatie tussen de zeven - uit de 24 variabelen ontwikkelde - faktoren en de verzuimmaten. 
Dat zal dus een soort samenvatting van de relaties tussen de verklarende en afhankelijke variabelen betreffen.

\subsection{De relaties van de 24 verklarende variabelen met het verzuim}

Om te beginnen kan eraan herinnerd worden dat alle variabelen in deze analyse een behoorlijke spreiding vertonen. Van elke variabele komen dus zowel hoge als lage waarden voor, zodat eventuele lage korrelaties tussen variabelen niet geweten zullen kunnen worden aan gebrekkige spreiding van de variabelen.

Tabel 7.4 (p. 202-203) geeft de nulde-orde korrelaties, de bètakoëfficiënten en de multipele korrelaties tussen de 24 verklarende variabelen en de drie verzuimmaten. In tegenstelling tot de replikatie-analyse worden in deze vervolganalyse dus geen partiële korrelaties maar partiële regressie- (of bèta)koëfficiënten berekend. Deze kunnen in feite beter gebruikt worden indien tussen de te relateren variabelen een vorm van afhankelijkheid wordt verondersteld, hetgeen bij (partiële) korrelatie-koëfficiënten niet het geval behoeft te zijn. De bèta-koëfficiënt drukt namelijk uit hoeveel 'eenheden' de afhankelijke variabele verandert als de verklarende variabele één 'eenheid' verandert (de effekten van alle andere verklarende variabelen uitgeschakeld). In de replikatie-analyse in het vorige hoofdstuk $z i j n$ géén bèta-koëfficienten gebruikt ondat Philipsen die in $z i j n$ analyse ook niet had berekend.

Tabel 7.4 laat zien dat zeven van de 24 variabelen op 5-procentsnivo een signifikante invloed hebben op de verzuimf rekwentie (als ook de gemiddelde duur per geval onder kontrole wordt gehouden):

- lage gemiddelde leeftijd produktiepersoneel $\quad \beta=.36$

- hoog percentage buitenlandse produktiewerknemers $\beta=.32$

- sterke band met GAK/Bedrljfsvereniging $\quad \beta=.19$

- weinig personeelsbegelelding en -zorg $\quad \beta=.17$

- geringe autonomie in de bedrijfsvoering $\quad \beta=.16$

- hinderlijke fysieke werkomstandigheden $\quad \beta=.14$

- slechte 'naam' van het bedrijf $\beta=.14$

Als een signifikantienivo van 10 procent wordt gehanteerd, vertonen ook de volgende drie variabelen nog een betekenisvol verband met de verzuimf rekwentie: 
- relatief grote personeelsafdeling

- slechte financieel-ekonomische positie bedrijf $\quad \beta=.12$

- bedrijfsgrootte

$\beta=.11$

Met betrekking tot de gemiddelde dur per verzuingeval zijn er acht van de 24 variabelen signifikant op het 5-procentsnivo:

- sterke band met GAK/Bedrijfsvereniging

$\beta=.34$

- hoog percentage buitenlandse produktiewerknemers

$\beta=.26$

- bedrijf autoritair geleid

$\beta=.18$

- veel kontakten over zieke werknemers

$\beta=.18$

- onrust in het produktieproces (nieuwe versie)

$\beta=.17$

- slechte 'naam' van het bedrijf

$\beta=.16$

- lage scholingsgraad wan het werk

$\beta=.16$

- hinderlijke fysieke werkomstandigheden

$\beta=.14$

En voorts $z i j i n$ er op het 10-procent signifikantienivo nog drie variabelen die de gemiddelde verzuimduur verhogen:

- hoog percentage ploegendienst merknemers

$\beta=.14$

- geringe autonomie in de bedrijfsvoering

$\beta=.13$

- geringe snelheid in de verzuimkontrole

$\beta=.13$

Tenslotte volgen nu de negen signifikante samenhangen op het 5procentsnivo tussen de verklarende variabelen en het verzuimpercentage:

- sterke band met GAK/Bedrijfsvereniging

$\beta=.37$

- hoog percentage buitenlandse produktiewerknemers

$\boldsymbol{\beta}=.36$

- lage scholingsgraad van het werk

$\beta=.21$

- lage gemiddelde leeftijd produktiepersoneel

$\beta=.21$

- geringe autonomie in de bedrijfsvoering

$\beta=.20$

- slechte 'naam' van het bedrijf

$\beta=.19$

- veel kontakten over zieke werknemers

$\beta=.19$

- hinderlijke fysieke werkomstandigheden

$\beta=.17$

- bedrijf autoritair geleid

$\beta=.17$

Alsmede de volgende drie variabelen op het 10-procentsnivo:

- onrust in het produktieproces (nieuwe versie) $\quad \beta=.17$

- slechte financleel-ekonomische positie bedrijf $\beta=.13$

- welnig personeelsbegeleiding en -zorg

$\beta=.12$

Voorts kan er nog op gewezen worden dat in tabel 7.4 twee soorten bèta-koëfficiënten vermeld worden, namelijk die warbij de zogenaamde alternatieve verzuimmat niet en waarbij deze wel onder kontrole wordt gehouden. Door deze rekenwijze valt te zien wat het effekt is van het al dan niet konstent-houden ven de alternatieve verzuimmat op het resultaat (zie voor toelichting p. 162). 


\begin{tabular}{|c|c|c|c|c|c|}
\hline \multicolumn{3}{|c|}{$\begin{array}{l}\text { gemiddelde verzuimduur per geval } \\
\qquad 1980 / 81\end{array}$} & \multicolumn{3}{|c|}{$\begin{array}{l}\text { verzuinpercentenge } \\
1980 / 81\end{array}$} \\
\hline $\begin{array}{l}\text { korrelaties } \\
\text { (oe-arde) }\end{array}$ & $\begin{array}{l}\text { beta-koèf- } \\
\text { fictënten }\end{array}$ & $\begin{array}{l}\text { beta-knëf- } \\
\text { ficienten d }\end{array}$ & $\begin{array}{l}\text { korrelaties } \\
\text { (oe-orde) }\end{array}$ & $\begin{array}{l}\text { beta-koëf - } \\
\text { ficlënten }\end{array}$ & \\
\hline $.25 * *$ & $.21 *$ & $.1 .4 *$ & .12 & .13 & 4 \\
\hline $.18 * *$ & .08 & $.14 * *$ & $.32 * * *$ & $.17 * *$ & $s$ \\
\hline$-.16^{*}$ & $-.15^{*}$ & $-.16 * *$ & $-.34 * * *$ & $-.21 * *$ & 6 \\
\hline .11 & .10 & .08 & $-.18 * *$ & .05 & 7 \\
\hline .01 & -.05 & $-.13 *$ & -.05 & $-.20 * *$ & 8 \\
\hline-.10 & .04 & .10 & .05 & .08 & 10 \\
\hline $.20 * *$ & $.18^{* *}$ & $.18^{* * *}$ & $.33 * * *$ & $.17 * *$ & 11 \\
\hline $.21 * *$ & .10 & $.16 * *$ & $.40 * * *$ & $.19 * *$ & 12 \\
\hline $.33 * * *$ & $.33 * * *$ & $.34 * *$ & $.33 * * *$ & $.37 * * *$ & 16 \\
\hline $.39 * * *$ & $.27 * * *$ & -.03 & -.10 & $-.21 * *$ & 17 \\
\hline $.14^{*}$ & $.14 *$ & .05 & -.08 & .02 & 19 \\
\hline \multicolumn{3}{|c|}{$---------\cdots--\cdots-\cdots$} & \multicolumn{3}{|c|}{$-\ldots-----m-\ldots-n$} \\
\hline-.02 & $.18^{*}$ & $.17 * *$ & .10 & $.17 *$ & 20 \\
\hline .03 & .05 & .04 & $-.19 * *$ & .06 & 21 \\
\hline .07 & .07 & .06 & .09 & .05 & 22 \\
\hline .04 & .05 & .11 & .09 & .11 & 23 \\
\hline $.23 * *$ & .11 & -.03 & .10 & $-.12 *$ & 24 \\
\hline $.1 B^{* *}$ & .03 & .10 & $.26 * * *$ & $.13 *$ & 25 \\
\hline .05 & -.01 & .04 & $.23 * *$ & .02 & 26 \\
\hline$-.2 \theta^{* * *}$ & $-.20 * *$ & $-.13 *$ & -.01 & -.09 & 27 \\
\hline $.32^{* * *}$ & $.24 * * *$ & $.118 *$ & $.25 * * *$ & $.19 * *$ & 28 \\
\hline $.20 *$ & .10 & $.26 * *$ & $.48 * *$ & $.36^{* * *}$ & 29 \\
\hline .05 & .05 & .01 & $-.16^{*}$ & -.02 & 30 \\
\hline$-.21 *$ & -.11 & -.06 & .03 & -.04 & 31 \\
\hline-.05 & -.10 & -.04 & .13 & -.05 & 32 \\
\hline-.48 & - & $-.60 * * *$ & $.39 * * *$ & - & \\
\hline- & - & - & $.59 * * *$ & - & \\
\hline - & .78 & .85 & - & .82 & \\
\hline
\end{tabular}

duur niet konstant wordt gehouden is deze relatie verwaar loosbaar ( $\beta=.02$ ), maar als de duur wel konstant wordt gehouden wordt deze relatie signifikant $(\beta=.19)$.

Bij de gemiddelde duur per geval doet zich het ongekeerde verschijnsel voor bij de variabele leeftijd. De relatie leeftijd duur loopt namelijk terug van .27 near -.03 als de frekwentie konstant wordt gehouden. Dus de nulde-orde relatie leeftijd - 
verzuimdur is "kunstmatig" hoog, ondat de relatie leeftijd frekwentie zo sterk is.

Wat betreft de multipele korrelaties valt opnieuw de hoge verklaerde variantie van het verzuim op. De 24 variabelen verklaren 66 procent $\left(=.81^{2}\right)$ van de variantie in de frekwentie, 61 procent $\left(=.78^{2}\right)$ van de variantie in de gemiddelde duur, en 67 procent (= $.82^{2}$ ) van de variantie in het verzuimpercentage.

Voorts blijkt dat met deze 24 variabelen slechts iets méér variantie verklaard wordt dan met de oorspronkelijke negentien variabelen ult het replikatie-onderzoek (hoofdstuk 6). Het is niet eenvoudig - door de onderlinge vervlechting van de variabelen om aan te geven waaraan dit precies ligt. Maar globaal kan wel gekonkludeerd worden dat de eliminatie van de variabele uitkeringsvoorwarden bij ziekte (vanwege geringe spreiding en geringe inhoudsvaliditeit) en de vervanging van de variabele niet-uitgewerkte organisatiestruktuur doar de minder verklarende variabele grootte van de groepen waarschijnlijk vooral debet zijn an het feit dat de multipele korrelaties mar weinig hoger zi.jn dan bij de replikatie-analyse met de negentien variabelen.

De nulde-orde verbanden van de dertien toegevoegde variabelen (20 tot en met 32) zijn ook nog getoetst op eventuele kromlijnige samenhang met de drie verzuimmaten. Dit gebeurde opnieuw door middel ven polynomiale regressie-analyse. Op deze wijze werden drie van de $39(13 \times 3)$ verbanden als signifikant (tweedegraads) kromlijnig geidentificeerd. Dit betekent dus dat bij deze drie variabelen de tweedegraads kromme een signifikante bijdrage toevoegt aan de verklaring van de afhankelijke variabele door de eerstegraads kromme (ofwel rechte lijn). Signifikante derdegraads kromme verbanden werden overigens niet aangetroffen.

De figuren 7.1 tot en met 7.3 ( $p .205$ ) tonen deze drie verbanden in sterk 'gestroomlijnde' vorm. Het gaat allereerst om de relatie tussen variabele 20 (onrust in het produktieproces) en de verzuimfrekwentie, welke nulde-orde relatie in lineaire zin $r=.16$ is en in lineaire plus kromlijnige $z$ in veel hoger (multipele $R=$ .32). Een hage en een lage mate van onrust gaat dus samen met een lagere verzuimfrekwentie dan een 'gemiddelde' mate van onrust in het produktieproces. In andere bewoordingen: procesproduktie zonder storingen en enkelstuksproduktie met veel storingen hebben 
Figuur 7.1 De recht11jnige en kromlijnige vorm van de relatie produktieprocestype (veriebele 20) - verzuinf rekwentie

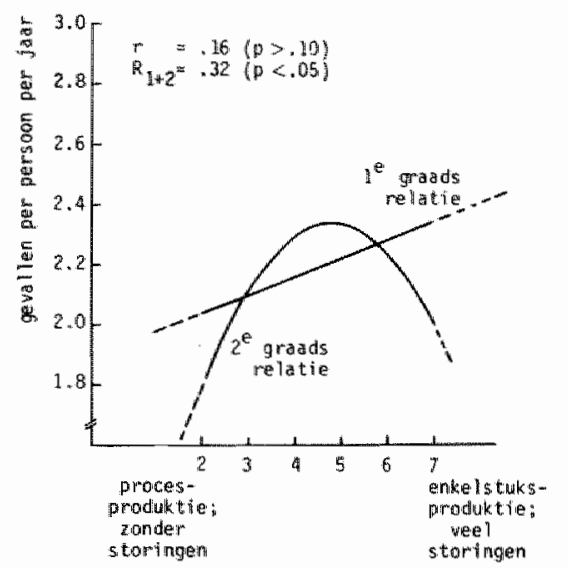

Figuur 7.2 De rechtiljnige kromlijnige vorm van de rellatie buitenlandse werkenmers (varlebele 29) - verzuimpercentege

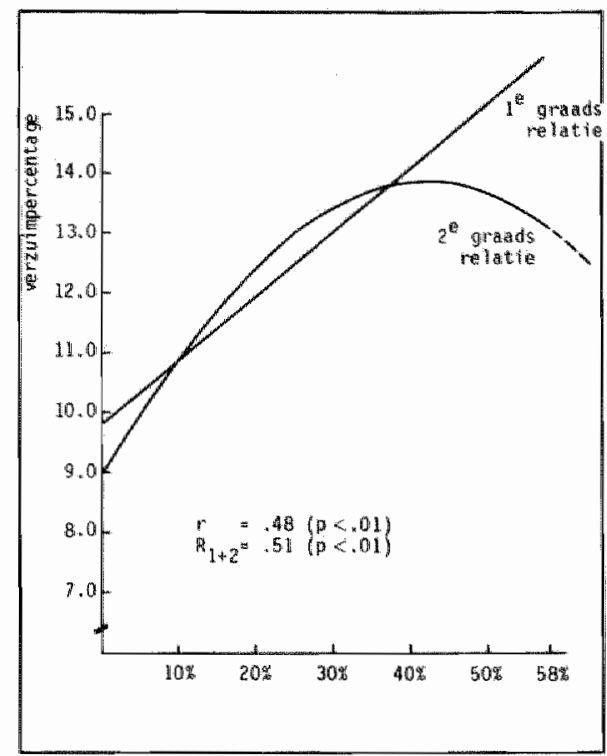

Figuiur 7.3 De rechtlijnige en kromlijnige vorm van de relatie socianl leiderschap (variabele 30) - verzuimf rekwentie

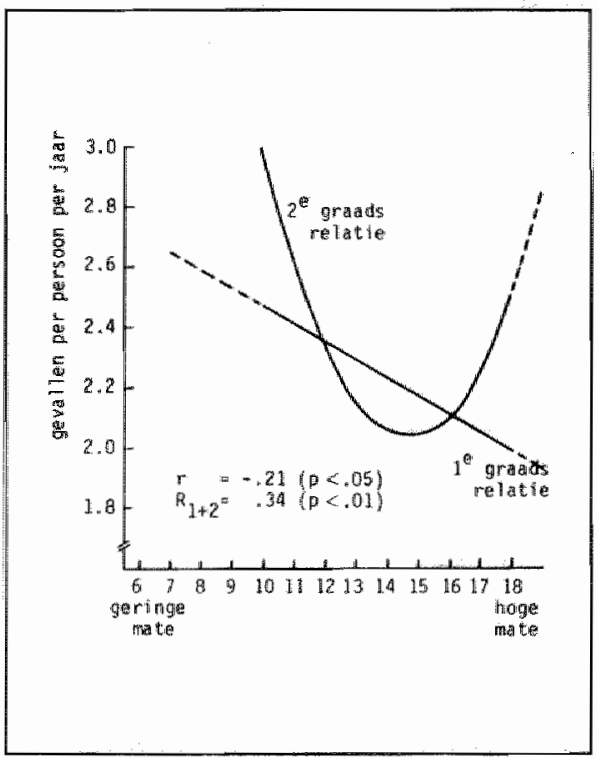


een lagere verzuimfrekwentie dan serie- en messaproduktie met een gemiddeld aantal storingen.

Eenzelfde soort effekt is warneembar bij de relatie tussen variabele 29 (het percentage buitenlandse werknemers) en het verzuimpercentage. Daar doet zich namelijk een tendens voor dat de gelijktijdige stijging van het verzuimpercentage te zamen met de atijging van het percentage buitenlandse werknemers minder wordt bij grote percentages buitenlanders. Mogelijk spelen homogeniteits- en heterogeniteits-effekten hier een rol, dat wil zeggen dat als het personeelsbestand uit merendeels Nederlanders of uit merendeels buitenlanders bestaat, dit minder 'schadelijk' is voor het verzuimpercentage dan als het personeel uit bijna evenveel Nederlanders als buitenlanders bestaat.

De rechtlijnige relatie tussen variabele 29 en het verzuimpercentage is $r=.48$, terwijl de multipele karrelatie met het verzuimpercentage van de rechtlijnige samen met de kromlijnige komponent $R=.51$ bedraagt. De kromlijnige bijdrage is dus maar gering, hoewel wel signifikant.

De derde en laatste aangletroffen kromlijnige relatie betreft het verband tussen variabele 30 (sociaal leiderschap) en de verzuimfrekwentie. Deze U-relatie impliceert dat er een optimum-mate aan sociaal leiderschap moet zijn voor een lage verzuimfrekwentie. Dus als er heel weinig of juist heel veel sociaal leiderschap in een bedrijf anwezig is, is er relatief een hogere verzuimfrekwentie. De lineaire nulde-orde relatie met de frekwentie is $r=$ -.21 , terwijl het recht- en kromlijnig verband met de frekwentie te zamen $\mathrm{R}=.34 \mathrm{is}$.

\subsection{Toetsing van de hypothesen}

In tabel 7.5 (p. 208) zijn de hypothesen met betrekking tot de vervolganalyse per hoof dkoncept vermeld. Van variabele 12 ('naam" van het bedrijf) werd verondersteld dat deze géén relatie zou hebben met verzuim. Tevens zijn in tabel 7.5 de resultaten van de regressieanalyse vermeld.

\section{De relaties met de verzuimf rekwentie}

Met betrekking tot 21 van de 23 variabelen werden hypothesen opgesteld over het verband met de verzuimfrekwentie. Geen signifi- 
kante verbanden met de frekwentie werden er verwacht ten aanzien van de snelheid van de verzuimkontrole en het antal kontakten over zieke werknemers (respektievelijk 27 en 28).

De vraag is nu welke hypothesen bevestigd of ontkracht werden. Wat betreft de verzuimnoodzaak werden twee van de drie hypothesen met de frekwentie bevestigd (werkomstandigheden en percentage buitenlandse werknemers). Het veronderstelde positieve verband met ploegendienst werd in de praktijk niet gevonden.

Het feit dat de toegevoegde bindingsvariabelen (uit de groep 20 tot en met 32) zo weinig invloed hebben op de frekwentie, behoort tot de meest opvallende resultaten van de vervolganalyse. Een aantal van deze variabelen, zouls vrijheid in de taakuitvoering, groepsgrootte, sociaal en instrumenteel leiderschap, invloedsverschillen, grootte personeelsafdeling - waarvan theoretisch verwacht werd dat ze effekten op de frekwentie zouden hebben - blijken daar niet relevant voor te zij.jn.

Mede op basis van de resultaten uit de replikatie-analyse (hoofdstuk 6) kan echter gekonkludeerd worden dat instrumentele en sociale binding aan de werksituatie toch wel invloed heeft op verzuimfrekwentie. Men denke aan de variabelen werkomstandigheden, scholingsgraad, autonomie in de bedrijfsvoering, bedrijfsgrootte en de wijze van bedrijfsleiding, die in de replikatie-analyse alle in de verwachte richting wezen. Dit is in de vervolganalyse ook het gevel (behalve bij scholingsgraad en de wijze van leidinggeven, die door partialisering met nieuwe variabelen niet meer signifikant $z i j n)$. Het koncept binding aan de werksituatie kan dus niet als niet-relevant afgedaan worden.

De koncepten organisatie-oriëntatie van de werknemers respektievelijk sociale verzuimkontrole werden door vijf variabelen gerepresenteerd. Vier darvan vallen echter ook onder andere hoofdkancepten. De enige exklusieve 'verzuimgelegentieidsvariabele' is stedelijkheidsgraad van de omgeving. Het veronderstelde positieve verband van stedelijkheidsgraad met de frekwentie werd niet teruggevonden in de data.

Met betrekking tot de relatie tussen ekonomische en/of verzekeringstechnische verzuimkontrole en de verzuimfrekwentie tenslotte werden drie hypothesen opgesteld, warvan alleen die over de band met GAK/Bedrijfsvereniging bevestigd kon worden. De andere twee variabelen (financieel-ekonomische positie van het bedrijf en werkloosheidspercentage rayon) bleken een positief respektieve- 
Tabel 7.5 Toetsing wan de hypothesen uit de vervolganalyse

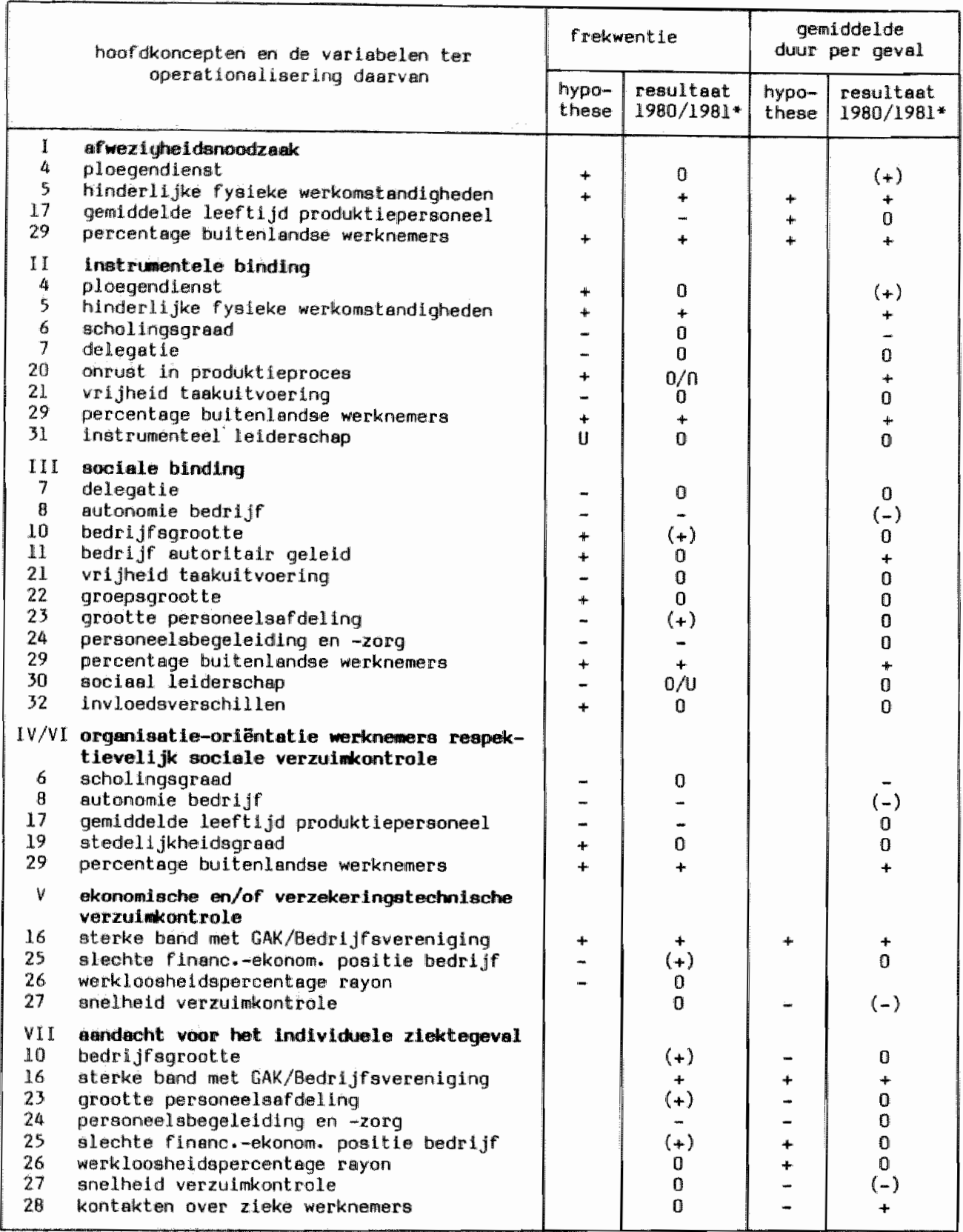

* - de signifikante relaties beta-koëfficiënten op $5 \%$-nivo bij konstent-houding van de alternatieve verzulmmaat) zijin met een + of - angegeven; zie basis-informatie uit tabel 7.4

- de beta-koëfficlënten die op het la\%-nivo signifikant zlfin, zijn met een + of tussen haak jes weergegeven;

- bij de variabelen 20 en $30 \mathrm{zijn}$ de kromlijnige be-orde relaties met de frekwentie tevens vermeld 
$1 i j k$ geen verband met de frekwentie te hebben in plaats van het veronderstelde negatieve verband.

\section{De relaties met de verzuinduur}

Er zijn elf variabelen waarvan verondersteld werd dat ze in verband zouden staan met de gemiddelde verzuimduur per geval (zle tabel 7.5).

Van de hypothesen met betrekking tot hun relatie met de verzuimduur bleken er vier bevestigd te kunnen worden (werkomstandigheden, band met het GAK/Bedrijfsvereniging, snelheid verzuimkontrole en percentage buitenlandse werknemers). Het verband tussen kontakten over zieke werknemers en de gemiddelde duur bleek niet negatief, maar juist positief te zijn. De verbanden van de andere zes variabelen bleken niet-signifikant te zijn (bedrijfsgrootte, leeftijd, grootte personeelsafdeling, personeelsbegeleiding en -zorg, financieel-ekonomische positie bedrijf en werkloosheidspercentage rayon).

Op basis van deze resultaten kan men de algemene konklusle trekken dat afwezigheidsnoodzaak en afwezigheidsgelegenheid zeker een rol spelen in de gemiddelde duur per verzuimgeval. Over het derde theoretisch koncept in dit verband - aandacht voor het individuele ziektegeval - bestaat ernstige twijfel wat betreft het verzuimduurbeperkende effekt. Van de veronderstelde verbanden met de verzuimduur van de acht indikatoren voor dit koncept (bedrijfsgrootte, band met GAK/Bedrijfsvereniging, grootte personeelsafdeling, personeelsbegeleiding en -zorg, financieel-ekonomische positie bedrijf, werkloosheidspercentage rayon, snelheid verzuimkontrole en kontakten over zieke werknemers) kon alleen het verband met band met GAK/Bedrijfavereniging en snelheid verzuimkontrole bevestigd worden. In het replikatie-onderzoek (hoofdstuk 6) bleek ook reeds dat de in dit kader opgevoerde variabelen ontwikkelde personeelsfunktie en professionele personeelsbegeleiding geen verzuim-beperkende effekten hadden. De konklusie lijkt nu wel gerechtvaardigd dat de omvang en aktiviteiten van de personeelsafdeling weinig of geen beperkende invloed op de verzuimduur uitoefenen. Het opvallende verschijnsel doet zich zelfs voor dat veel kontakten tussen de personeelsafdeling, de produktieleiding en de verzekeringsarts over zieke werknemers (variabele 28) samengaan met langere verzuimduren in plaats van kortere. Mogelijke oorzaken thiervan werden reeds aangegeven bij de beschrijving van deze variabele (p. 126-127). 
Verder kan nog opgemerkt worden, zoals dat in hoofdstuk 6 reeds gebeurde, dat de bindingsaspekten niet alleen met de frekwentie maar ook met de duur te maken blijken te hebben. Van de toegevoegde bindingsindikatoren staan onrust en percentage buitenlandse werknemers ook in verband met de duur. Op dit punt behoeft de theorie van Philipsen dus aanvulling.

Tenslotte nog enige opmerkingen over de validiteit van de toegevaegde variabelen. Crossvalidatie van deze nummers 20 tot en met 32 met eerdere resultaten, zoals dat in paragraaf 6.6 gebeurde, is hier uiteraard niet mogelijk. De resultaten van de faktoranalyse (tabel 7.3, p. 190/191) lijken echter allemaal plausibel. Geheel onverwachte resultaten zijn niet te ontwaren, zodat kritische kanttekeningen bij de inhoudsvaliditeit van de dertien toegevoegde variabelen achterwege kunnen blijven.

De voorspellende waarde (prediktieve of criterium-validiteit) van de toegevoegde variabelen laat echter wel een en ander te wensen over. Alleen de hypothesen met betrekking tot de relatie met verzuimfrekwentie en/of duur van de variabelen 24 (personeelsbegeleiding en -zorg), 27 (snelheid verzuimkontrole) en 29 (percentage buitenlandse werknemers) konden bevestigd worden (zie tabel 7.5). De hypothesen rond de andere verklarende indikatoren kwamen niet uit. Deze zijn dus geen goede voorspellers van verzuimfrekwentie en/of duur, maar - en dat dient wel toegevoegd te worden - dat ligt dus niet aan een gebrek an hun inhoudsvaliditeit, zoals hierboven beargumenteerd is.

\subsection{Integratie van de resultaten}

Hiervoor is nogal gedetailleerd op de resultaten van de analyse ingegaan. Dat heeft voordelen, maar kan ook enigszins het zicht op het totaalbeeld van het onderzoek ontnemen.

Het wordt dan ook tijd te komen tot een integratie van de onderzoeksresultaten. Hiertoe moeten we teruggaan naar de faktoranalyse van de 24 verklarende variabelen (tabel 7.3, p. 190/191). Daarin werden de 24 verklarende variabelen gereduceerd tot zeven centrale faktoren. Elk van de 24 verklarende variabelen korreleert in een bepalde mate met deze zeven centrale faktoren. Die korrelatie wordt de 'lading' van de variabele op de betreffende 
faktor genoemd. Sommige variabelen korreleren zeer sterk met één faktor en in te verwarlozen mate met de andere zes faktoren. Andere 'laden op meer dan een faktor', dat wil zeggen korreleren in behoorlijke mate met meer dan één faktor.

De zeven gevonden faktoren dekken overigens de theoretische koncepten (binding, noodzaak, gelegenheid, etcetera) niet. De bindingsaspekten zijn vooral terechtgekomen op faktor I (kwaliteit van het werk en de menselijke verhoudingen) en faktor $V$ (aandacht voor de individuele werknemer), maar verdere kombinaties zijn niet te identificeren.

Nadat de faktoranalyse uitgevoerd was, zijn aan alle 85 bedrijven in het onderzoek zeven scores toegekend voor elk van de zeven faktoren. Een voorbeeld kan dit duidelijk maken. De belangrijkste variabelen op faktor I zijn hoge scholingsgraad, veel delegatie, veel vrijheid, weinig buitenlandse werknemers en weinig instrumenteel leiderschap. Een bedrijf nu dat op deze variabelen hoog scoort, krijgt dus ook een hoge score op faktor I. Alle andere verklarende variabelen tellen uiteraard ook mee - ook die met een heel geringe lading -, alleen zijin ze van weinig tot te verwarrlozen belang voor de score. Elk van de 24 variabelen telt dus in gewogen mate mee voor de score van een bedrijf op de faktor. De faktorscores zijn gestandaardiseerde scores, want het gemiddelde van alle 85 bedrijven is op 500 gesteld. De standaard-deviatie van elke faktor is ook gestandaardiseerd: elke faktor heeft een standaard-deviatie van 100 .

$\mathrm{Nu}$ is van de zeven faktorscores nagegaan welke hun korrelatie is met de drie verzuimmaten. De zeven faktorscores hebben - door de varimax-rotatie - géén of een te verwaarlozen onderling verband. Dus bij het korreleren van een faktorscore met een verzuimmat is het niet nodig dat de andere zes faktorscores onder kontrole worden gehouden.

De nulde-orde korrelaties van de zeven faktoren met de drie verzuimmaten zijn in tabel 7.6 weergegeven. Ook zijn de relaties met de frekwentie berekend bij konstanthouding van de gemiddelde duur en de relaties met de gemiddelde duur bij konstanthouding van de frekwentie. Dit zijn dus eerste-orde korrelaties en daarop zullen de konklusies - zoals steeds - gebaseerd worden.

Het blijkt dat de verzuimf rekwentie door drie faktoren sterk verhoogd wordt: 
Tabel 7.6 De nulde-orde korrellaties, de partiële korrelatles van de eerste orde en de multipele korrelatiea tusisen de zeven faktoren (gebaseerd op 24 variabelen) en de orie verzulmaten $(n=85)$

\begin{tabular}{|c|c|c|c|c|c|c|}
\hline & \multirow[t]{2}{*}{ de zeven fuktoren } & \multicolumn{2}{|c|}{$\begin{array}{l}\text { verzuinf rekwentie } \\
\qquad 1980 / 81\end{array}$} & \multicolumn{2}{|c|}{$\begin{array}{l}\text { gentiddelde } \\
\text { verzulinduur } \\
\text { per geval } \\
1980 / 81\end{array}$} & $\begin{array}{l}\text { verzulimpercent age } \\
\qquad 1980 / 81\end{array}$ \\
\hline & & \multicolumn{2}{|c|}{$\begin{array}{c}\text { korrelaties } \\
0^{e} \text {-ordle } 1^{\mathrm{e}} \text {-orde }\end{array}$} & \multicolumn{2}{|c|}{$\begin{array}{c}\text { korrellaties } \\
\text { oe-orde }^{e} 1^{e} \text {-orde }\end{array}$} & $\begin{array}{l}\text { korrelaties } \\
\text { oe-orde }^{\mathrm{e}}\end{array}$ \\
\hline $\mathbb{1}$ & $\begin{array}{l}\text { kwaliteit werk en men- } \\
\text { selijke verhoudingen }\end{array}$ & $-.39 * * *$ & $-.44 *$ & -.02 & $-.24 * *$ & $-.37 * * *$ \\
\hline II & $\begin{array}{l}\text { atutomet I ser ingegraad } \\
\text { produkt ieproces }\end{array}$ & $-.17^{*}$ & .03 & $.30 * 4 *$ & $.33 * * *$ & $.18 * *$ \\
\hline 111 & $\begin{array}{l}\text { korrelotien van vergte- } \\
\text { delljking }\end{array}$ & -.04 & .00 & .07 & .02 & .03 \\
\hline IV & $\begin{array}{l}\text { slechte financ.-ekon. } \\
\text { positie bedrijf }\end{array}$ & $.17 *$ & $.36 * * *$ & $.29 * * *$ & $.42 * * *$ & $.45+\cdots$ \\
\hline$v$ & $\begin{array}{l}\text { andecht voor de lindi- } \\
\text { widuele werknemer }\end{array}$ & $-.20 * *$ &.- .10 & $.25 * * *$ & $.14 *$ & .08 \\
\hline VI & $\begin{array}{l}\text { geniddelde leeftifd } \\
\text { personeelstuestand }\end{array}$ & $-.50 * * *$ & $-.38 * *$ & $.36 * * *$ & $.14 *$ & -.015 \\
\hline VII & $\begin{array}{l}\text { moderne organisatie- } \\
\text { wijze }\end{array}$ & .07 & -.02 & $-.23 * *$ & $-.25 * * *$ & $-.17^{*}$ \\
\hline \multicolumn{2}{|c|}{ multipele karrelatie } & .69 & - & .65 & - & .64 \\
\hline
\end{tabular}

* aignifikant bij $p=.10$ (eenzljdig; $r=.14)$

* algnifikant bij $p=.05$ (eenzijdig; $r=.18$ )

** slgnifikant bij $p=.01$ (eenzijdig; $r=.25$ )

a gemiddelde verzulmduur per geval konstant gehouden

b verzuimf rekwent le kanstant gehouden

- slechte kwaliteit van werk en menselijke verhoudingen

$r=.44$

- lage gemiddelde leeftijd van het personeelsbestand

$r=.38$

- slechte financieel-ekonomische positie van het bedrijf

$r=.36$

De gemiddelde verzuimduur per geval wardt door vier faktoren beparld:

- slechte financieel-ekonomische positie van het bedrijf

$r=.42$

- automatiseringsgraad van het produktieproces $\quad r=.33$

- traditionele organisatiewijze

$r=.25$

- slechte kwaliteit van werk en menselijke verhoudingen 
Op het 10-procentsnivo spelen ook nog twee faktoren een rol:

- veel (1) aandacht voor de individuele werknemer

$$
\begin{aligned}
& r=.14 \\
& r=.14
\end{aligned}
$$

- hoge gemiddelde leeftijd personeelsbestand

Het verzuimpercentage is de resultante van frekwentie en duur en mordt door drie faktoren in verhogende zin beïnloed:

- slechte financieel-ekonomische positie van het bedrijf

$y=45$

- slechte kwaliteit van het werk en menselijke verhoudingen

$r=.37$

- hoge automatiseringsgraad van het produktieproces

$r=.18$

En op het 10-procentsnivo is tenslotte nog van belang:

- traditionele organisatiewijze

$r=.17$

De andere faktoren spelen hierbij geen rol van betekenis.

Twee faktoren blijken in dit onderzoek dus een overheersende rol te spelen. De kwaliteit van het werk en de menselijke verhoudingen en de financieel-ekonomische positie van het bedrijf zljn namelijk zowel aan de frekwentie als an de gemiddelde duur sïgnifikant gerelateerd. Niet verwonderlijk is dus dat ze samen de verschillen tussen de bedrijven ten aanzien van het verzuimpercentage beheersen.

De bevinding dat de kwaliteit van het werk en de menselijke verhoudingen het verzuimpercentage sterk bepaalt zal niet verbazen. Daarover zijn eerdere onderzoeksresultaten eenduidig.

Diverse stromingen en theorieën in de psychologie en de sociologie (de Human Relations-school, de socio-techniek, taakontwerp/ -verrijking/-roulatie, het Job Characteristica Model, Lelderschaps-, machts- en invloedstheorieën) hebben als gemeenschappelijke basis dat verloop en verzuim in organisaties beperkt wordt door gevarieerde en autonome taken en door goede menselijke verhoudingen. In globale zín ondersteunden de resultaten uit het onderhavige onderzoek deze theoretische denkbeelden dus.

In figuur 7.4 worden de relaties van deze faktor 1 met de drie verzuimmaten grafisch voorgesteld. De 85 bedrijven $z i j n$ hiervoor in drie ongeveer even grote groepen onderverdeeld.

Bij een goede financieel-ekonomische positie van het bedrijf zijn voornamelijk de variabelen goede financieel-ekonomische positie van het bedrijf, goede 'naam", goede werkomstandigheden en demokratische bedrijfsleiding van belang. 
Fl guur 7.4 De relaties tusaen kwalltelt wan het werk en de menselijke werhoudingen (faktor I) en de drie verzulmmaten
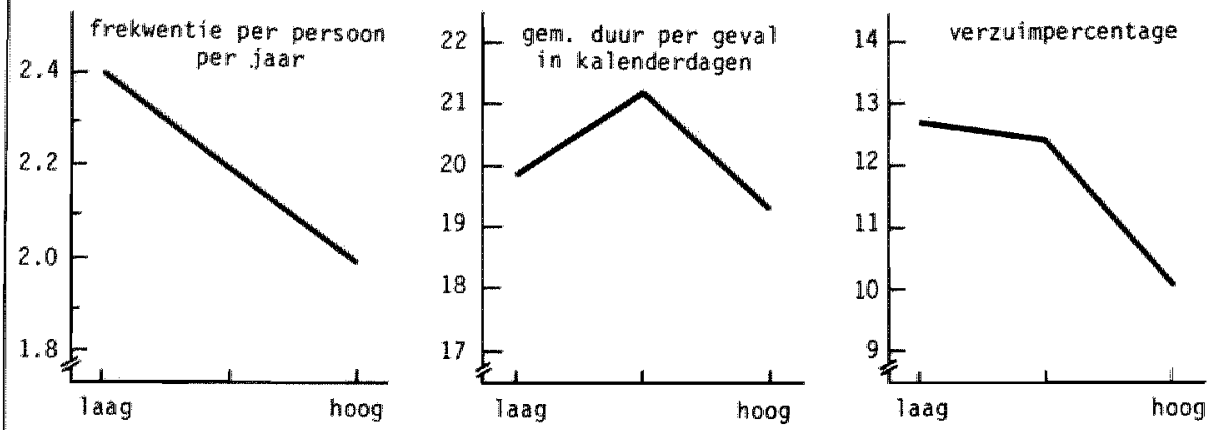

Figuur 7.5 geeft de relaties weer met de drie verzuimmaten van deze faktor IV.

Flguur 7.5 De relaties tussen financieel-ekonomische positie van het bedrijf (faktor IV) en de drie verzulimmaten
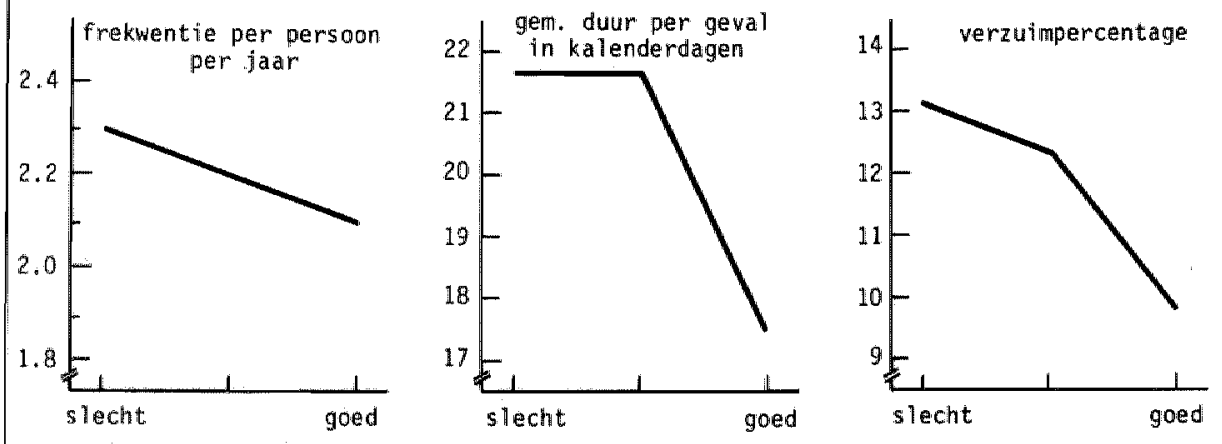

Over de invloed van de financleel-ekonomische positie en andere konjunkturele aspekten van het bedrijf op het gedrag van de werknemer is relatief weinig onderzoek gedaan.

Owens (1966) vand in haar onderzoek in Engeland, dat bekendheid van werknemers met de toekomstige sluiting van hun spoorwegwerkplaats zowel hun frekwentie als verzuimduur deed stijgen in de 
drie maanden voorafgaande aan de feitelijke sluiting. Dok Handy (1968) konkludeerde dat, over een periode van negen jaren, het verzuimpercentage in de Engelse mijnbouw steeg indien het aantal bedrijfssluitingen in de bedrijfstak toenam. Voorts konstateerde Van Dijkhuizen (1980) bij 578 werknemers uit zeventien Nederlandse industriële bedrijven dat, indien zij hun toekomst als onzeker ervoeren, zij ook een hoger verzuimpercentage vertoonden. Tenslotte zijn nog twee onderzoeken beschikbaar met enigszins on-orthodoxe verzuimmaten, die vorenstaande bevindingen ondersteunen. Wiersma (1979) kon in zijn onderzoek in Groningen onder 205 mannelijke werknemers met een ziektegeval van tenminste 10 weken (in de kategorie ongeval of ziekte van de bewegingsorganen) vaststellen dat werkzaamheid in een ekonomisch kwetsbaar bedrijf samengaat met relatief lange ziekteduren. Ook in het zogenaamde WAOdeterminantenonderzoek (De Jong et al., 1981) onder 2000 werknemers is nagegaan welke de invloed is van financleel-ekonomische bedrijfsaspekten op de kans op langdurig verzuim en WAO-intrede. Hoe zwakker het bedrijf geacht werd door de werkgever van de betreffende werknemer, hoe groter de kans dat er in dat bedrijf langdurige ( 5 -maands-) ziektegevallen en WAO-gevallen antstaan, was de konklusie uit het onderzoek.

Alleen onderzoek van Dijkstra (1974) en Ris (1978) met behulp van het begrip inkrimping van het personeelsbestand leidt tot de konklusie dat ekonomische problemen in een bedrijf een verlagend ef fekt hebben op respektievelijk de frekwentie en de duur.

De resultaten van de hier gerapporteerde analyse lijken met betrekking tot de verzuimduur dus over het algemeen ondersteund te worden door de resultaten van het eerder uitgevoerde empirische onderzoek op dit terrein. Dat eerder onderzoek had namelijk zelden betrekking op de verzuimfrekwentie (alleen Owens, 1966), maar meestal op het verzuimpercentage en/of de duur. In de hier verslagen studie wordt echter gevonden dat een slechte financieelekonomische positie eveneens samengaat met een hoge frekwentie. Dat is nieuw en was ook niet verondersteld.

Zoals reeds eerder opgemerkt, moet er dus sprake zijn van een vergrote verzuimgelegenheid (verminderde kontrole) en een vermindering van eandacht voor het individuele zlektegeval bij bedrijven die in financieel-ekonamisch opzicht slecht lopen.

Tenslotte houdt de faktor lage graad van automatisering het ver- 
zuimpercentage laag. Meer gedetailleerd betekent dit dat enkelstuksproduktieprocessen met hun relatief hoog geschoold werk en weinig ploegendienst (maar wel met veel storingen en onrust), iets minder delegatie van verantwoordelijkheden en meer produktie-gericht leiderschap een lager verzuimpercentage vertonen. Het feit dat deze processen zich lets meer in kleinere bedrijven afspelen heeft ook lets met het lagere verzuimpercentage te maken. Overlgens moet men bij de geautomatiseerde produktieprocessen niet alleen denken aan chemische bedrijjven, maar ook aan bijuvoorbeeld blik-, cement-, meel- en andere levensmiddelenfabrieken, die in continu-proces werken. In paragraaf 8.5 wordt meer in detail op deze materie (onder andere op de frekwentie- en duurverschillen) ingegaan. Figuur 7.6 geeft de relaties weer van de faktor automatiseringsgraad met de drie verzuimmaten.

Figur 7.6 De relaties tussen automatiseringsgraad van het produktieproces (faktor II) en de drie verzuimmaten

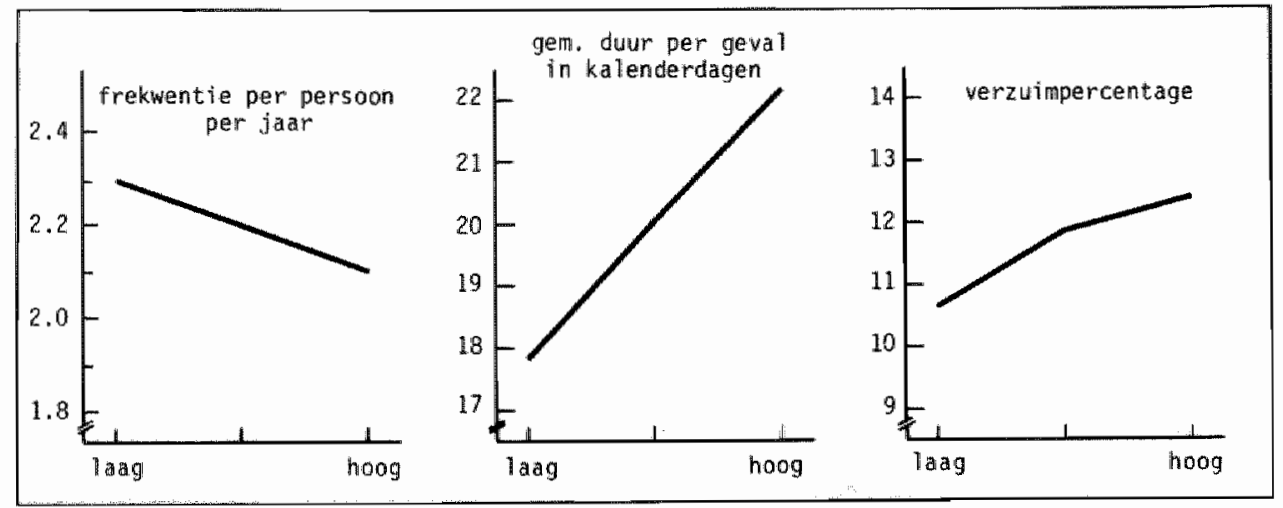

Tenslotte geven de figuren 7.7 tot en met 7.10 de relaties weer van de vier overblijuende faktoren met de drie verzuimmaten. Bij deze vier faktoren is de relatie met het verzuimpercentage steeds niet-signifikant ( $p=.05$ ).

De faktor korrelaten van verstedelijking (figuur 7.7) vertoont ook geen relaties met frekwentie en duur. Aandacht voor de individuele werknemer heeft een verlagend effect op de verzuimfrekwentie en een verhogend effect op de gemiddelde verzuimduur. Figuur 7.8 laat echter zien dat beide verbanden kromlijnig zijn. De 
kromlijnigheid is echter niet signifikant. Bij een gemiddeld oud personeelsbestand is de frekwentie relatief laag en de gemiddelde duur relatief lang (figuur 7.9 ). Tenslotte hebben moderne organisaties een kortere duur dan traditionele organisaties, hetgeen in beperkte $z$ in in het verzuimpercentage doorwerkt (figuur 7.10). Frekwentieverschillen zijn er niet tussen moderne respektievelijk traditionele organisatiewijze.

Figuur 7.7 De relaties tussen korrelaten van verstedelijking (faktor III) en de drie verzulimmatery
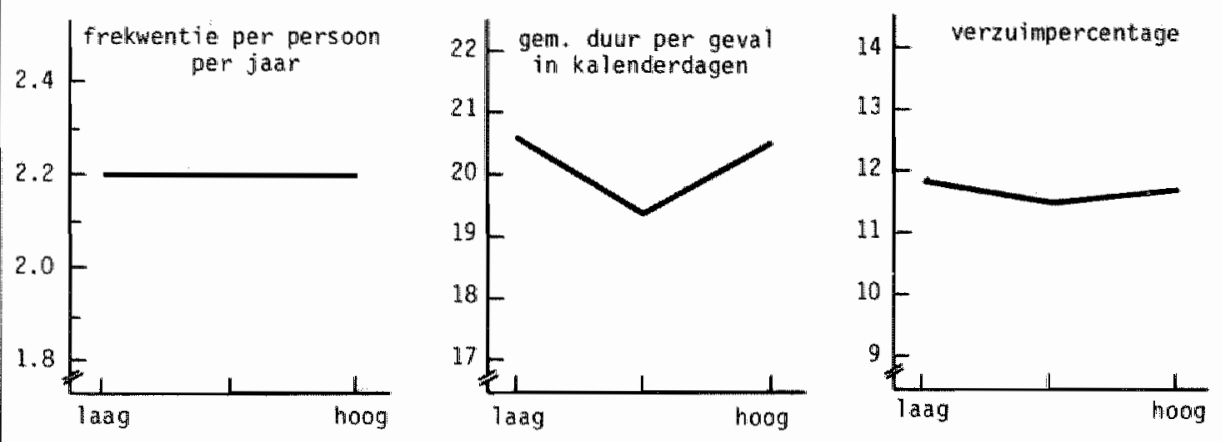

Figuur 7.8 De relaties tussem eandacht voor de indlviduele werknemer (faktor $V$ ) en de drie verzuimmaten

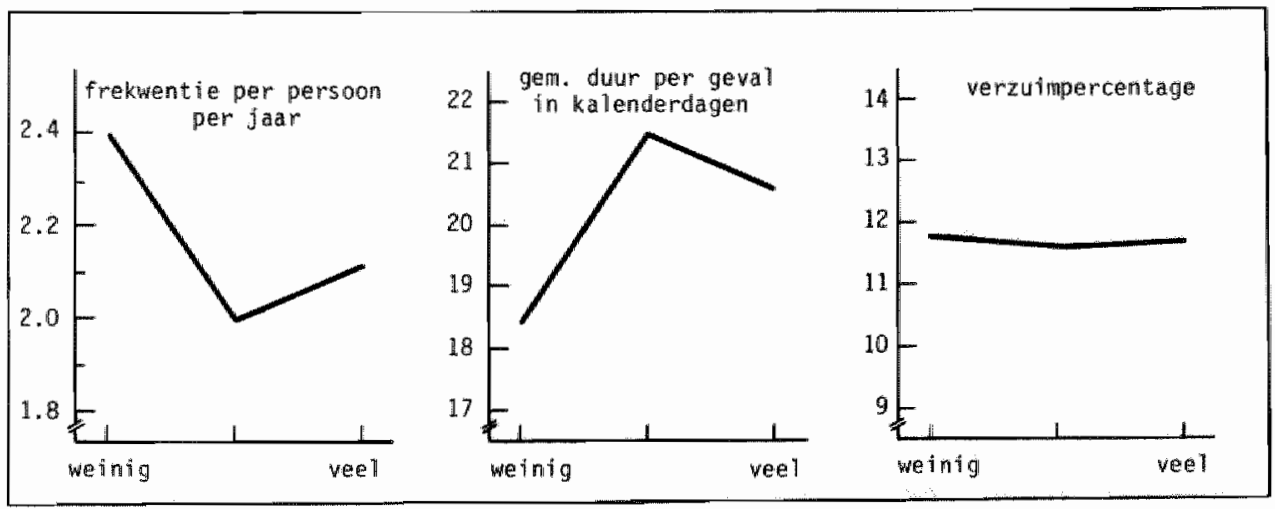


Figuur 7.9 De relettes tussen gemiddelde leeftijd van het personeelsbestand (f aktor VI) en de drie verzulimaten
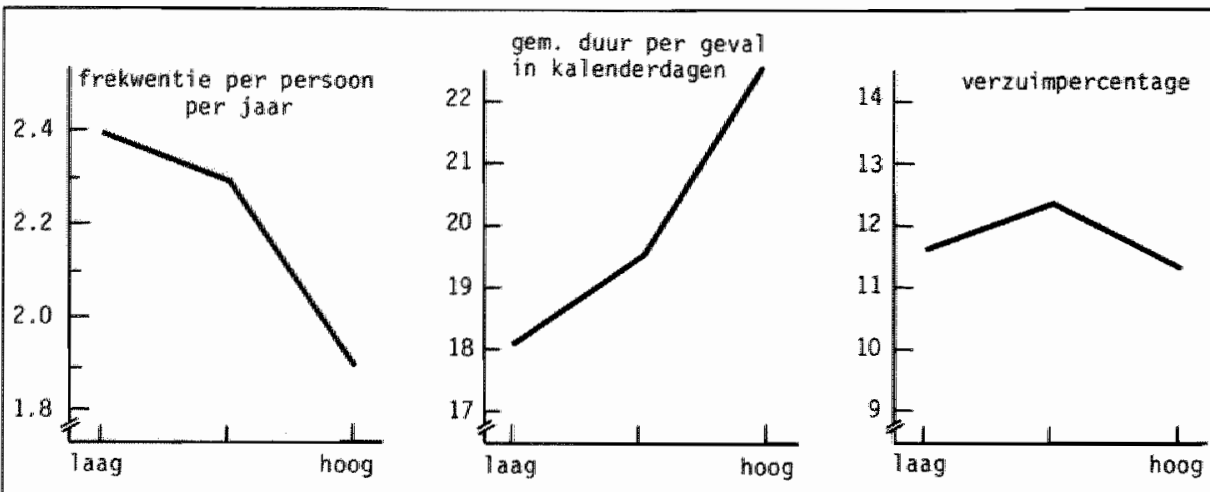

Figuur 7.10 De relaties tussen traditionele/moderne organisatle (faktor VII) en de drie verzulimmaten
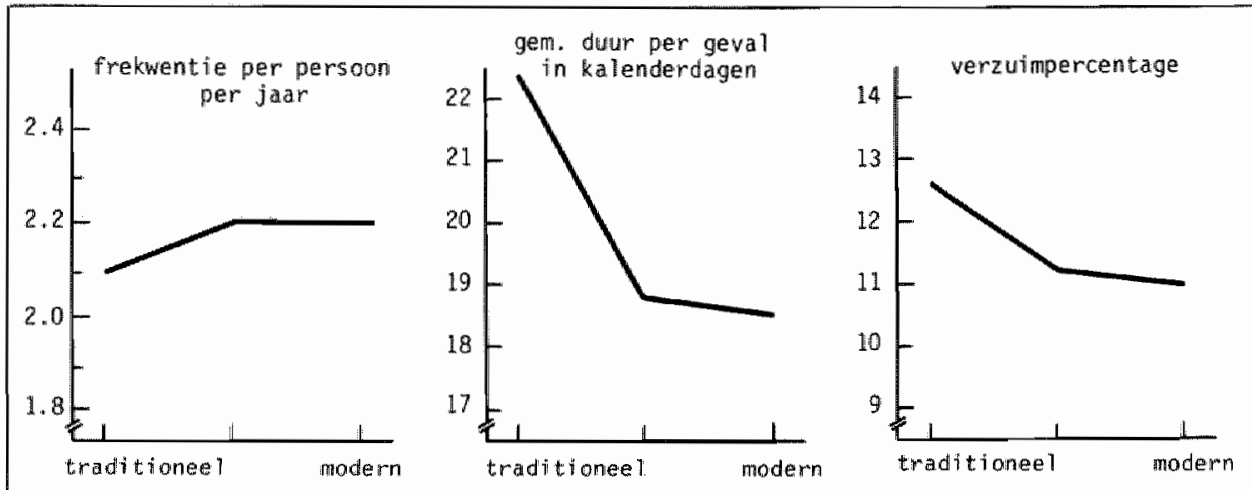

7.7 Analyses van enige kausale modellen met behulp van de LISREL-techniek

De vier voor het verzuimpercentage belangrijkste faktoren (kwalitelt van het werk en de menselijke verhoudingen, automatiseringsgraad van het produktieproces, financieel-ekonomische positie van het bedrijf en traditionele/moderne organisatie) zullen nu met de statistische techniek LISREL (Jöreskog \& Sörbom, 1978) onder de loupe genomen worden. De vraag rijst namelijk - nadat is vastgesteld dat deze vier faktoren van belang zijn voor het verzuimper- 
centage - of voor de variabelen die binnen deze faktoren voorkomen èn het verzuimpercentage, een plausibel kausaal model opgesteld kan worden dat te verenigen is met de tussen die variabelen optredende karrelaties of kovarianties. Het voordeel van het opstellen en toetsen van kausaliteitsketens is, dat er meer van het proces datleidt tot verzuim in bedrijven mee blootgelegd kan worden. Men denke in dit verband ook aan de in hoofdstuk 2 aangeduide verschillen tussen inhoudelijke en proces-theorieën.

Eerst iets aver de analysetechniek zelf. Met LISREL (afkorting van Linear Structural Relations) kan nagegaan worden in hoeverre een theoretisch model te rijmen valt met de werkulijk gevonden samenhangen. Met LISREL is echter niet uit te maken of een model 'juist' is ("de werkelijkheid weergeeft'). Want, ook al zijn het model en de bevindingen met elkar te verenigen, dan nog blijft het mogelijk dat andele modellen eveneens bij de gegevens passen, misschien zelfs beter of 'juister'. Omgekeerd kan men er wel mee tot de kanklusie komen dat het model hoogstwaarschijnlijk niet 'juist' is, namelijk in het geval dat de aampassing van het model aan de korrelaties of kovarianties slecht is.

In LISREL wordt onderscheid gemaakt tussen latente onafhankelijke en afhankelijke variabelen, die via een meetmodel verbonden zijn met de waarneembare onafhankelijke en afhankelijke variabelen. In de hierna volgende analyses worden de latente variabelen en de waarneembare variabelen an elkaar gelijk gesteld. De korrelaties tussen de onafhankelijke (exogene) variabelen worden als gegeven beschouwd, maar 'tellen' wel mee in het model; de afhankelijke (endogene) variabelen hangen via regressievergelijkingen van exogene variabelen en/of van elkaar af. Bovendien zijn op de afhankelijke variabelen 'storingstermen' (buiten het model gellegen invloeden, afwijkingen van lineariteit van de samenhangen, en dergelijke) werkzaam.

De koëfficiënten in de regressievergelijkingen, de varienties van de storingstermen en eventueel kovarianties tussen storingsternen (dit zijn de grootheden of de parameters van het model) worden vervolgens geschat. Per grootheid wordt een $t$-waarde berekend die aangeeft of de grootheid signifikant van 0 afwijkt. Voor het hele model wordt een Chi-kwadraat-grootheid berekend die aangeeft in hoeverre het model te rijmen valt met de observaties. Hoe lager deze Chi-kwadraat-waarde (rekening houdend met de vrijheidsgra- 
den), hoe geringer het verschil tussen schattingen op basis van het model en de empirische data.

Een voordeel van LISREL boven de enigszins vergelijkbare pad-analysetechniek is, dat LISREL ook gekorreleerde storingsfouten (restvarianties) in de varm van wederzijdse pijlen (zie de figuren) in het model kan opnemen. Essentieel bij de analyse met LISREL is dus dat de onderzoeker zelf eerst de variabelen, met redenen omkleed, rangschikt in een kausaal model. Dit blijkt overigens hier niet in details, mear slechts in grote lijnen mogelijk.

$E_{r}$ is als volgt te werk gegaan. Omdat faktor I (kwaliteit van het werk en de menselijke verhoudingen) en faktor II (automatiseringsgraad van het produktieproces) beide betrekking hebben op de inhoud van het werk - hetgeen ander meer tot uitdrukking kamt in het feit dat scholingsgraad en delegatie op beide faktoren laden (zie tabel 7.3, p. 190/191) - werd getracht beide faktoren als één geheel te analyseren. Wel zijn alleen de belangrijkste hoogstladende - variabelen binnen de twee faktoren in het model opgenomen. Bedrijfsgrootte, sociaal leiderschap en invloedsverschilllen werden daarom buiten beschouwing gelaten.

Allereerst werd een viertal verklarende (in LISREL-termen: exogene) variabelen onderscheiden. Van deze werd het plausibel geacht dat ze de andere variabelen zouden beïnvloeden. Deze vier werden verondersteld te zijn: scholingsgraad van het werk, vrijheid in de taakuitvoering, ploegendienst en onrust in het produktieproces. Deze variabelen werden dus geacht per bedrijf min of meer stabiel vast te liggen. Het zijn zaken die het systeem van het produktieproces en het soort werk beschrijven. Eventuele verandering in hun waarde lijkt slechts langzaam in de tijd te bewerkstelligen.

Vervolgens werden vijf variabelen geïdentificeerd die geacht werden af te hangen van of beinvloed te worden door bovengenoemde vier exogene variabelen. In LISREL-termen worden ze endogene varlabelen genoemd. Deze vijf zijn: snelheid van verzuimkontrole, percentage buitenlandse produktiewerknemers, autoritaire wijze van bedrijfsleiden, instrumenteel leiderschap en delegatie. Uit de theoretische en empirische literatuur over leiderschap en centralisatie van invloed in organisaties is voldoende bekend om te kunnen stellen dat delegatie, autoritaire bedrijfsleiding en instrumenteel leiderschap onder meer afhangen van kenmerken van 
het produktiesysteem, zoals de inhoud van het werk (zle bijvoorbeeld Payne \& Pugh, 1976). Bepaalde leiderschapstheorieën, zoals de kontingentietheorie en de path-goal-theory (zie House \& Baetz, 1979) hebben situationele faktoren zelfs expliciet als determinanten opgenomen. Ook Dijkstra (1977) konkludeerde op basis van zijn onderzoek dat bedrijfsgrootte en produktie-omvang determinanten zijn van de mate van demokratisch leiderschap in organisaties. Voorts werd ook van de snelheid van verzuimkantrole verwacht dat deze deels beïnvloed zou worden door kenmerken van het produktiesysteen en het soort werk. Hiervoor waren bij de interviews met de bedrijfsleiders en personeelschefs tijdens het onderzoek eveneens indikaties opgevangen. Tenslotte werd ervan uitgegaan dat het percentage buitenlandse werknemers af zou hangen van het soort werk dat het bedrijf te bieden heeft.

Verder werden er nog twee endogene variabelen onderscheiden die zowel van exogene als endogene in het model voorkomende variabelen afhankelijk zouden zijn, namelijk: het verzuimpercentage (gebruik van frekwentie en duur apart werd om redenen van eenvoud vermeden) en de 'naam' van het bedrijf. Deze laatste variabele is hier dus niet als verklaring voor verzuim gezien. Er werd van uitgegaan dat beide in grate lijnen door dezelfde oorzaken beïnvloed zouden worden. De hierboven aangedulde vier exogene en zeven endogene variabelen zijn in figuur 7.11 (p. 222) weergegeven. Het is duidelijk dat het onmogelijk is om puur op theoretische gronden of op basis van eerder empirisch onderzoek rekenschap te geven van alle verbanden in het model. Daarom merd verder gebruik gemaakt van de gevonden korrelaties tussen de variabelen onderling om de verbanden in het model te postuleren. Op grond van deze empirische gegevens werd een aantal kausale verbanden gepostuleerd tussen de vier exogene en de zeven endogene variabelen en een aantal kausale verbanden tussen de endogene variabelen (waaronder het verzuimpercentage en 'naam') onderling. Voorts werd verondersteld dat de storingstermen bij instrumenteel leiderschap en delegatie, bij delegatie en autoritaire wijze van bedrijfsleiden, bij autoritaire bedrijfsleiding en percentage buitenlandge werknemers en die bij ziekteverzuim en de 'naam' van het bedrijf gekorreleerd zijn, om zo een deel van de tussen deze vier paren variabelen bestaande korrelaties te beschrijven zonder een kausale relatie tussen hen te hoeven postuleren. Op deze wijze werden de relaties toegeschreven aan de werking van variabelen buiten 
Flgut 7,11 de samentang war de belangrijkste warlabelen uit faktor I en II (kwallteit van het wert en de menselijke vertoudingen respektievelijk automatheringagralad war het produktieproces) samen met het verzuimpercentage, volgens een LISFEL IW-model

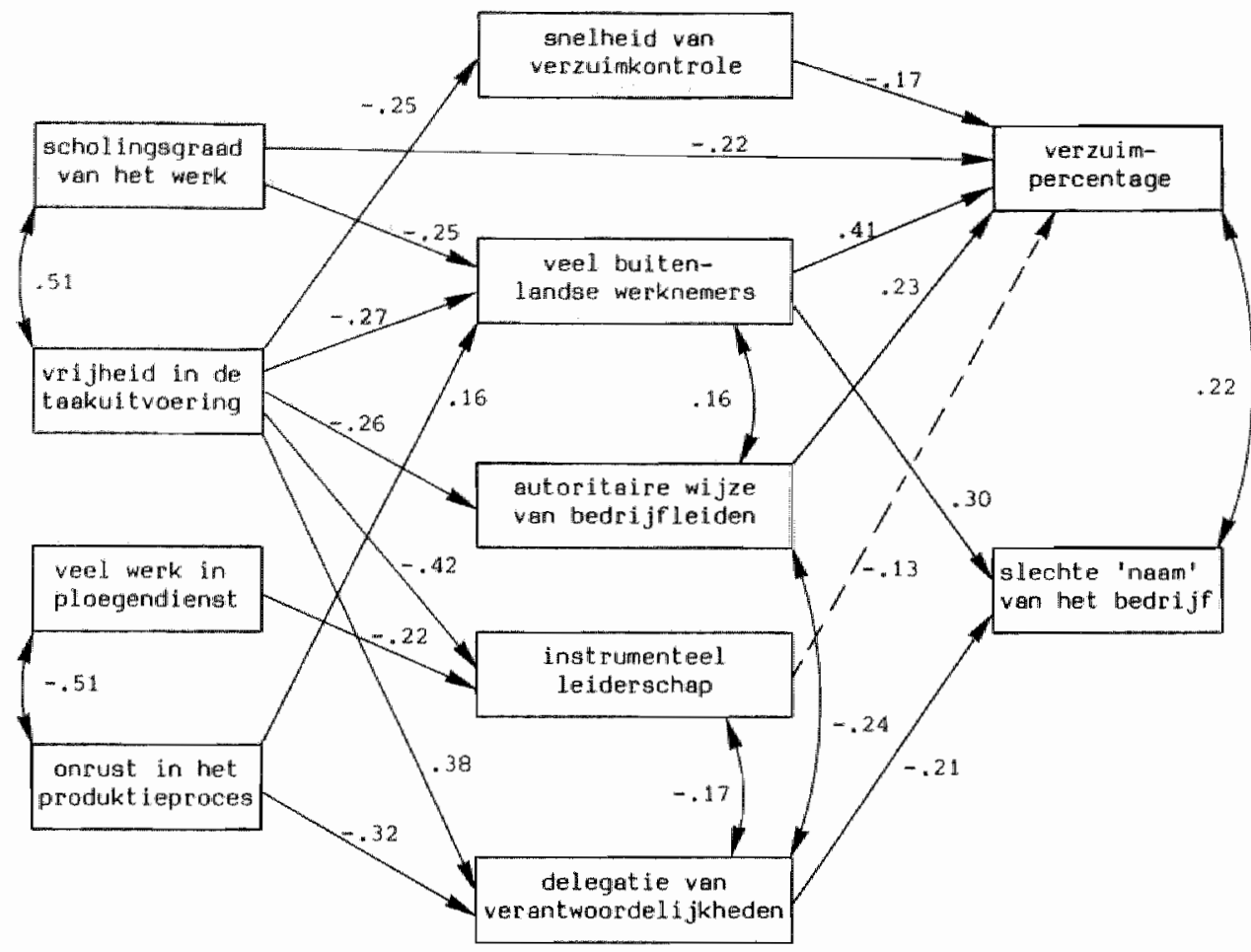

De 'goodmess of fit'-toets woor dit model:

chi-kwadraat $=19.0$ (met 29 wrijheidsgraden), warbij $p=.92$

De warden wan alle regressie-koëfficiënten zijn signifikant ( $p<.10$, tweezijoig), behalve die tolj de atippe 11 i.jn

De restvariantles (storingstermen) in de endogene variabelen (dat zijn de zeven pechter warlabelen) 21 jn voor:

- snelhetd van de verzulakontrolle $\quad .94$

- veel bultenlandse werknemers

- autoritalre wijze wan bedrijfleiden .93

- Instrumented lelderschap .76

- delegat de van verantwoordal ijkheden .77

- verzulinpercentage. $\quad .66$

- sleohte "naam" van het bedrijf .83

het model, die an elkaar gerelateerd zijn en verantwoordelijk worden geacht voor een deel van de onechte (spurious) relatie tussen de genoemde paren. Alle verbanden zijn in figuur 7.11 met een pijl aangegeven. 
De beschreven werkwijze betekent dat er niet een theoretisch kausaal model wordt getoetst dat van tevoren op basis van eerder onderzoek geformuleerd is. Het model is deels op basis van de empirische data zelf gekonstrueerd. Dat houdt in dat de LISREL-toets met betrekking tot de "goodness of fit" van het model een grote kans heeft gunstig uit te pakken. Er wordt dus als het ware geen model getoetst, maar meer op een exploratieve wijze een model gekonstrueerd. Het model, dat al zoekend gekonstrueerd is, wordt uiteindelijk met behulp van LISREL op zijn houdbaarheid onderzocht en de waarde van de erin voorkomende grootheden wordt geschat.

De resultaten zijn in figuur 7.11 weergegeven. Alle wel en niet in de figuur opgenomen verbanden behoren tot het getoetste model. Dok alle niet-vermelde verbanden doen dus mee in het model, mar zijn op nul gesteld. Ze zijn zo goed als zeker niet signifikant. Voor dit laatste zijn aanwijzingen omdat de LISREL-output door middel van residu-indikaties aangeeft of er nog betekenisvolle invloeden of gekorreleerde storingstermen buiten het model zijn gelaten. Met andere woorden: alle signifikante verbanden zijn zo goed als zeker vermeld èn in het model opgenomen. Dit geldt ook voor de relaties tussen de exogene variabelen. Hun onderlinge relaties en de invloeden op hen van variabelen buiten het model. worden voor lief genomen, dat wil zeggen: niet verder geanalyseerd, door de korrelaties tussen deze variabelen als gegeven te behandelen. Hun korrelaties 'tellen' dus wel mee voor het model. De 'goodness of fit'-test toont aan dat dit model zeer goed bij de empirische data past. De Chi-kwadraat is 19.0 , waarbij $p=$ .92 , hetgeen wil zeggen dat model en data goed op elkaar aanslutten. De konklusie zou aldus verwoord kunnen worden: 'het zou zó in elkaar kunnen zitten'.

Inhoudelijk kunnen uit het madel de volgende hoofdpunten gelicht worden:

- de vier exogene variabelen thebben bijna géén rechtstreekse invloed op het verzuimpercentage (behalve scholingsgraad), maar hun toch onmiskenbare invloed verloopt via de endogene (verzuimkontrole, aanwezigheid van buitenlandse werknemers, leiderschapsvormen, etcetera);

- van centrale invloed in het model is de vrijheid in de taakuittvoering; deze beïnvloedt alle víjf endogene variabelen in het midden van de figuur op signifikante wijze; 
- ook speelt het percentage buitenlandse werknemers een vrij centrale rol in het model; bedrijven met laaggeschoold werk, weinig vrijheid in de taaksituatie en een onrustig produktieproces nemen blijkbaar meer buitenlanders in dienst; vervolgens beïnvloedt de aanwezigheid van buitenlandse werknemers het verzuimpercentage en de 'naam' van het bedrijf;

- de exogene variabele (on)rust, die de kern van de faktor automatiseringsgraad vormt, laat zien dat in rustige, meer geautomatiseerde processen minder buitenlanders werken en dat daar relatief meer verantwoordelijkheid wordt gedelegeerd; bovendien wordt er in rustige geautomatiseerde produktieprocessen meer in ploegendienst gewerkt, welke situatie samengaat met minder instrumenteel, produktie-gericht leiderschap, hetgeen weer enigszins verzuimbevorderend werkt;

- het verzuimpercentage wordt beïnvloed door de snelheid van de verzuinkontrole, het aantal buitenlandse werknemers, autoritaire bedrijfsleiding en (in mindere mate) instrumenteel leiderschap;

- door de goede "fit" van het model lijkt de gedachte plausibel te zijn dat kenmerken van de technologie (het produktieproces) kenmerken van de organisatiestruktuur, met name leiderschapsgedrag, beïnvloeden.

Dan nu over naar het LISREL-model betreffende faktor IV, de financieel-ekonomische positie van het bedrijf. Olok dat model is deels op theoretische gronden, deels op basis van de empirische gegevens gekonstrueerd. Uitgangspunt waren de variabelen die hoog laden op faktor IV (zie tabel 7.3, p. 190/191).

In eerste instantie werd van de gedachte uitgegaan, op basis van kontingentie-theoretische overwegingen (zie de bespreking van faktor IV in paragraaf 7.3), dat de financieel-ekonomische positie van het bedrijf, als omgevings- of exogene variabele, leidt tot onrust/storingen in het produktieproces en tot een autoritaire wijze van bedrijfsleiden en mogelijk ook - hoewel dat niet logisch klinkt - tot een lage graad van instrumenteel leiderschap. Het verzuimpercentage, de 'naam' van het bedrijf en het werkloosheidspercentage van het rayon werden daarvan afhankelijk geacht te zijn. De plaatsing van het regionaal werkloosheidspercentage 
in dit model, namelijk als afhankelijk van de financieel-ekonomische positie van het bedrijf en de interne bedrijfssituatie, vraagt enige toelichting. De gedachte hierachter was namelijk dat slecht lopende bedrijven enigermate zullen bijdragen - door uitstoot van merknemers - aan de werkloosheid in hun omgeving.

Tenslotte $z i j$ nog vermeld dat ook de variabele werkomstandigheden in dit model als exogene variabele opgenomen was.

Wat bleek nu bij analyse? Dit kontingentie-theoretische model klopt slecht met de data volgens de 'goodness of fit"-toets. De Chi-kwadraat was bijna signifikant $(p=.06)$, hetgeen doet vermoeden dat het model voor verbetering vatbaar is.

Vervolgens $z i j n$ precies dezelfde variabelen gerangschikt volgens de pijlen van figuur 7.12 (p. 226). In dat model wordt de financieel-ekonomische positie van het bedrijf als endogene variabele afhankelijk geacht te zijn van autoritair en instrumenteel leiderschap en van onrust/storingen in het produktieproces. Omdat er geen duidelijke verbanden tussen de drie laatstgenoemde variabelen bestaan, werden ze alle drie als exogene variabelen opgevoerd.

Dit model nu blijkt goed te kloppen (Chi-kwadraat $=8.2$, waarbij $p=.70)$ ! Dok voor dit goed passende model geldt weer dat alle verbanden, die niet signifikant zijn, ook niet in het model opgenomen zijn (dus op nul gesteld) en dat de uiteindelijke 'goodness of fit'-toets alleen gebaseerd is op de in figuur 7.12 vermelde koëfficiënten. Zoals te zlen valt, wordt het verzuimpercentage indirekt door instrumenteel leiderschep en door onrust in het produktieproces beinvloed en well via de financieel-ekonomische positie van het bedrijf. Dit geldt ook voor autoritair leiderschap, maar deze variabele heeft ook nog een rechtstreekse invloed op het verzuimpercentage.

Tenslotte wordt het verzuimpercentage nog beïnvloed door hinderlijke fysieke werkomstandigheden. Deze laatste variabele neemt in het model een marginale positie in en is mede onder deze faktor terecht gekomen door $z i j n$ relatief sterke relatie met autoritaire bedrijfsleiding en de 'naam" van het bedrijf.

De plaats van het regionaal werkloosheidspercentage in het model, als zijnde kausaal beïnvloed door de financieel-ekonomische positie van het bedrijf, was zoals gezegd, gebaseerd op de gedachte dat slecht lopende bedrijven enigermate zullen bijdragen - door uitstoot van werknemers - aan de werkloosheid in hun omgeving. Nu 
Filgur 7.12 De sanientiang van de belangrijkste variabelen uit faktor IV (financieelekonomische positie van het bedrijf) samen met het verzuimpercentage, volgens cen LISREL IW-miodel

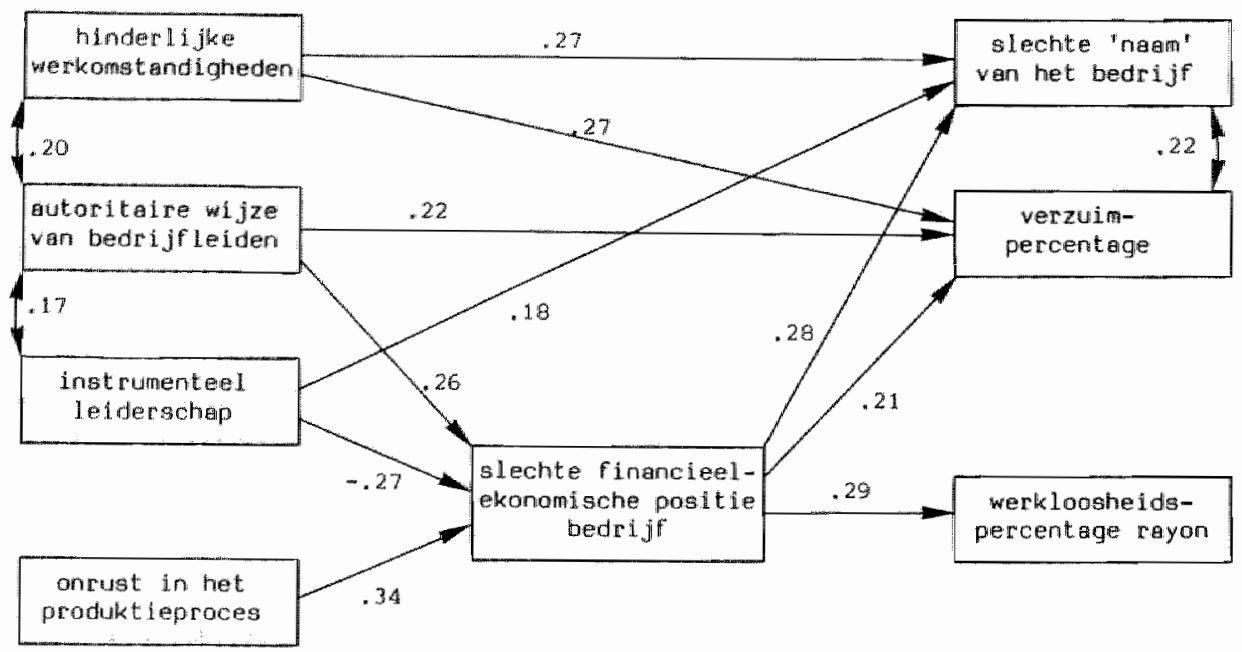

De 'goodnegs of fjt'-toets voor dit model:

chil wadrat $=0.2$ (met 11 vrijheidsgraden), warbij $p=.70$

De wararden van alle regressle-koüficiënten zijn signifikant ( $p<.10$, tweezijdig)

De fegtvarlanties (atoringhternen) in de endogene varlabelen (dat zijn de vier rechuer varibalen) 2 ijn woor:

- silechte francleel-ekonomische positie bedrijf .79

- siechte "naan' van het bedrijf .84

- verzuímipercentage.

- werkloosheidspercientage rayon $\quad .92$

is er ook nog nagegaan of een niat-kausale koppeling tussen deze twee variabelen goed in het model zou passen. Dit bleek niet het geval te zijn. Als de relaties tussen alle andere variabelen in het model in takt worden gelaten, blijkt een model met een nietkausale koppeling tussen de twee bedoelde variabelen veel slechter te kloppen met de data.

0verigens en tenslotte lijken de achtereenvolgens getoetste modellen met de variabelen uit faktor IV weinig ondersteuning op te leveren voor de in de organisatie-sociologie voorkomende kontingentiegedachte van de dreigende invloed van de amgeving - via de financieel-ekonomische positie van het bedrijf - op het funktioneren ervan. Veeleer roepen de modellen de veronderstelling op dat leiderschapsgedrag - met de andere variabelen - een funktie 
vervult in de financieel-ekonomische positie van het bedriff. Demokratisch en instrumenteel (produktie-gericht) leiderschap $l i j-$ ken namelijk beide bij te dragen tat een goede financieel-ekonomische positie.

Als afsluiting van deze paragraaf zal faktor VII, traditionele/ moderne organisatie, die ook - hoewel zwak - met het verzuimpercentage samenhing (zie tabel 7.6,p. 212), met de LISREL-techniek geanalyseerd worden. Zoals de faktoranalyse, tabel 7.3, laat zien, zijn autonomie in de bedrijfsvoering, autoritaire bedrijfsleiding, band met het GAK/Bedrijfsvereniging en relatieve grootte van de personeelsafdeling de sterkst ladende variabelen in deze faktor.

In navolging van eerder in deze paragraaf gevolgde redeneringen is ervan uitgegaan dat bij deze faktor enige variabelen als verklarend of exogeen aangemerkt zouden kunnen worden. In dit geval zijn dat autoritaire bedrijfsleiding, mate van ploegendienst en autonomie in de bedrijfsvoering (zie figuur 7.13). De eerste twee zijn al eerder als exogene variabelen opgevoerd; autonomie moet eveneens in deze kategorie ondergebracht worden ondat het een welhaast vastliggend, permanent kenmerk van een bedrijf is. Autoritaire bedrijfsleiding is ook in deze kategorie opgenomen omdat het gaat om leiding aan de top van de organisatie. Er wordt hier van uitgegaan dat dit een tamelijk stabiel soort gedrag is, dat slechts langzaam in de tijd verandert of kan veranderen.

Van genoemde drie kenmerken werd aangenomen dat ze invloed zouden uitoefenen op de vijf endogene variabelen. Zoals ook bij de eerdere LISREL-analyses het geval was, is bij de konstruktie van de rest van dit madel van de empirische data zelf uitgegaen. Meer in detail werd verondersteld dat een sterke band met het GAK af de Bedrijfsvereniging (het bedrijf is dan 'omslaglid" en doet de kontrole en administratie voor de Zlektewet niet zelf) het verzuimpercentage zou versterken (en niet andersom), zie figuur 7.13.

Bij deze laatste twee relaties zijn 'gespiegelde' verbanden tot op zekere hoogte in principe ook te verdedigen. Bij de eerste relatie dient men dan te bedenken dat bedrijuen met een hoog verzuimpercentage geneigd zullen $z i$.jn dit verzuimrisico te willen delen met andere bedrijuen en dus graag een (risico-delend)'omslaglid' zullen willen zijn. Dit betekent een sterke band met het 
Flguv 7.13 De samenhang van de belangrijkste variabelen uit faktor VII (traditionele/moderne organisatie) samen met het verzuimpercentage, volgens eien LISREL IV-model. (le alterratief)

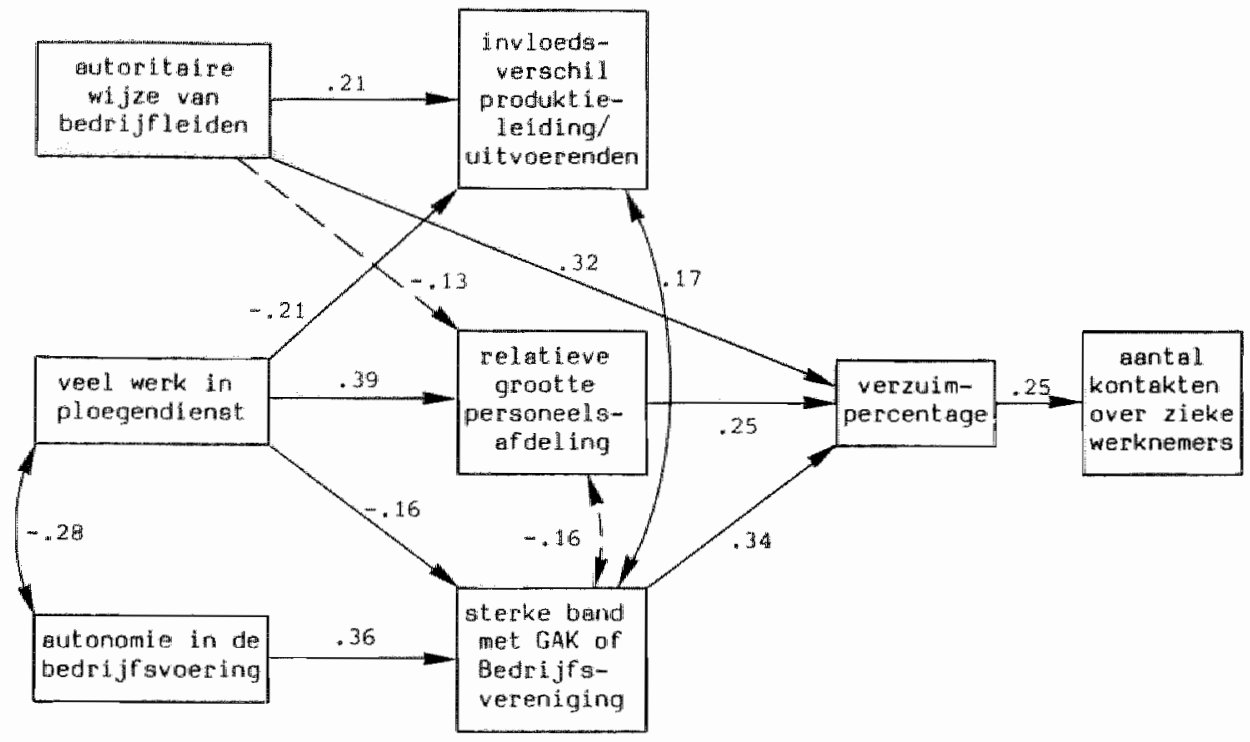

De 'goodness of fit'-toets voon dit modell:

chi-kwadrat $=12.8$ (net 13 vijheitsqraden), warbij $p=.46$

De warden war alle regressie-koëf flchënten zijn signifikent (p <. 10, tweezijdig getoetat), behalve die bij de twee relaties die in stippeli ijner zijn weergegeven

De regtwarianties (storingatermen) in de endogene variabelen $z i j n$ voor:

- Invloedswerschi 1 produktieleidung / witwoerenden .90

- relatieve grootte van de personelsafdeling .82

- sterke band net Gak of Bedrijfsvereniging . 82

- verzuimpercentage $\quad .76$

- aantal kontakten ower zieke werkmemers 94

GAK of de Bedrijfsvereniging. Bedrijven met een laag verzuimpercentage zullen - volgens deze redenering - het verzuimrisico van hun werknemers liever zelf willen dragen en dus graag afdelingskas of eigenrisicodragend bedrijf willen zijn, hetgeen een zwakke band met GAK of Bedrijfsvereniging betekent. Men duidt deze wens tot het veranderen van de verzekeringsvorm naar gelang de hoogte van het verzuimpercentage in de wereld van de sociale verzekering wel aan met het 'duiventil-effekt'.

Bij de tweede mogelijk te 'spiegelen' relatie kan men zich ook voorstellen dat veel kontakten over zieke werknemers verzuimbevorderend zullen zijn, als men bedenkt dat die kontakten zouden 
kunnen leiden tot doorverwijzingen naar speclalisten en/of ziekenhuizen.

Maar, zoals gezegd, eerst werden de laatste twee relaties getoetst zoals in figuur 7.13 is weergegeven. De 'goodness of fit'test voor het in dit figuur beschreven model levert een Chi-kwadraat op, waarbij een $p=.46$ hoort. Dit betekent dat model en data goed op elkaar aansluiten, maar dat toch nog gekeken kan worden of nog een verbetering mogelijk is. Zoals het figuur laat zien zijn alle tien kausale relaties (behalve die tussen autoritaire bedrijfsleiding en grootte van de personeelsafideling) signifikant. Beide gekorreleerde storingstermen, de twee bogen, zijn net wel en net niet signifikant.

Zoals al eerder vermeld, geeft een LISREL-oplossing ook indikaties wáár het model verbeterd kan worden. Dit bleek onder meer te zitten in een mogelijke relatie tussen het verzuimpercentage en de band met thet GAK/Bedrijfsvereniging in andere richting. Daarom is hetzelfde model ook nog eens getoetst met de relatie verzuimpercentage- band met GAK/Bedrijfsvereniging in omgekeerde richting.

Deze ingreep leidt tot een beter passend model, zoals figuur 7.14 laat zien. De Chi-kwadraat wordt veel lager, met $p=.93$, hetgeen duidt op een goede passendheid van model met data. Men kan ook $z$ ien dat de regressie-koëfficiënten in figuur 7.14 merendeels hoger zijn dan in figuur 7.13. Deze verbetering wil overigens niet zeggen dat het model uit figuur 7.13 zonder waarde is. Het is waarschijnlijk zo, dat er sprake is van een wederzijdse relatie tussen de band met GAK/Bedrijfsvereniging en het verzuimpercentage met een iets sterkere (= 'snellere') invloed van het verzuimpercentage op de band met GAK/Bedrijfsvereniging dan andersom. Het goed-passende model van figuur 7.14 dat geen verdere aanpassingen behoeft, is als volgt in zijn kern weer te geven. De 'verzekerings- en kontrolewijze voor de Ziektewet', zoals de band met GAK/Bedrijfsvereniging ook genoend kan worden, is de centrale variabele in dit model. Enerzijds valt de volgende cyclus war te nemen: autoritaire wijze van bedrijfsleiden leidt rechtstreeks tot een hoog verzuimpercentage, dat weer leidt tot een sterke band met GAK of Bedrijfsvereniging, hetgeen samengaat met een relatief kleine personeelsafdeling welke verzuimbeperkende effekten heeft. Anderzijds valt ook te zien dat een sterke band met GAK/ Bedrijfsvereniging bepaald wordt door een grote autonomie in de 
Flquir 7.14 De gamenhang wan de belangrijkste wariabelen uit faktor VII (traditionele/moderne organiagtie) samen met het verzuimpercentage, volgens een LISPEL IV-model (2e alternatief)

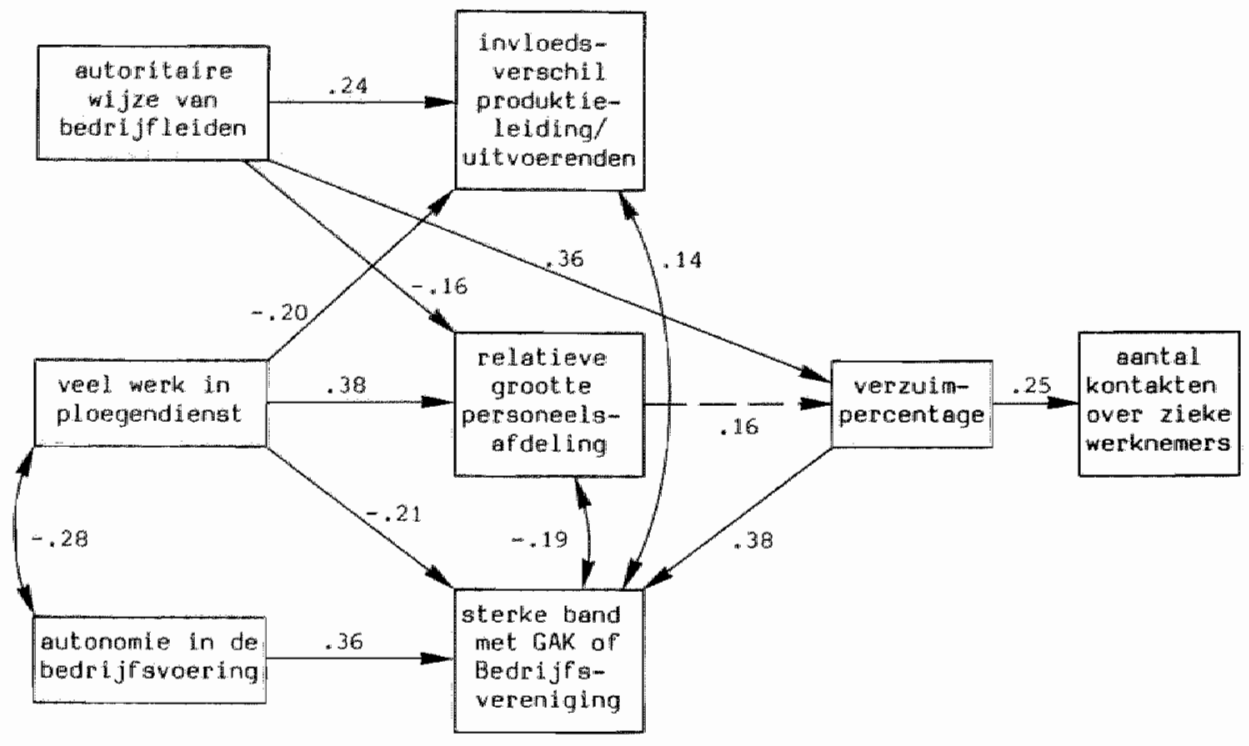

De 'goodness of flt'-toets waor dit model:

chi-kwadraat $=6.5$ (met 13 wrijheidsgraden), warbilj $p=.93$

De waarden van alle regressie-koëfficiënten zijn signiflkant $(p<.10$, tweezijdig getoetst), behalve die bij de relletie die als stippellijn is weergegeven

De restvarianties (storingstermen) in de endogene wariabelen zijn voor:

- irvloedsverschil produktieleiding / ulltwoerenden .89

- relatieve grootte van de personeelseffeling $\quad .82$

- sterke band met GAK of Bedrijfsvereniging .68

- verzuimpercentage $\quad .87$

- aantal kontakten over zieke werknemers $\quad .94$

bedrijfswoering (dus géén concern-onderdeel zijn) en een geringe mate van ploegendienst. De laatste twee variabelen hangen trouwens sterk negatief samen $(r=-.28)$.

Overigens heeft Draaisma (1983) als eerste in Nederland veel aandacht besteed aan de mogelijk wederzijdse relatie tussen de verzekeringsvorm voor de Ziektewet en het verzuimpercentage van bedrijuen. Op basis van zijn informatie kont hij tot de konklusie dat het verzuimpercentage van bedrijven er slechts in beperkte mate aanleiding toe is om daadwerkelijk van verzekeringsvorm te veranderen. Blijkbaar ligt dit bij de onderhavige steekproef van 85 bedrijuen toch lets anders. 
Een viertal aspekten van het model dienen verder nog benadrukt te worden. Ten eerste valt de centrale, determinerende rol van de variabele ploegendienst in deze faktor op. Bij faktor II, automatiseringsgraad van het produktiesysteem, hebben we al gezien dat ploegendienst daarin een belangrijke rol speelt. Hier ziet men nu dat een bedrijf met veel ploegendienstwerk gekenmerkt wordt door slechts kleine invloedsverschillen tussen de produktieleiding en de uitvoerenden, door een relatief grote personeelsafdeling (mogelijk zijn bij ploegendienst extra personeelsfunktionarissen nodig voor de administratie rond ploegendienstschema's, de inzet van personeel en allerlei extra-organisatorische problemen) en door het feit dat dit soort bedrijven vaker afdelingskassen of eigenrisicadragers zijn dan omslagleden.

Ten tweede zij erop gewezen dat in het model de kausale relatie verzuimpercentage $\rightarrow$ aantal kontakten over zieke werknemers goed past. Uitgeteste modellen warin de relatie andersom opgenomen was, bleken steeds minder goed bij de data te passen. Het lijkt er dus op - men moet voorzichtig blijwen - dat het aantal kontakten over zieken meer bepaald wordt door de hoogte van het verzuimpercentage dan dat de kontakten het verzuimpercentage beinvloeden.

Ten derde kan op het negatieve verband tussen de grootte van de personeelsafdeling en de band met GAK/Bedrijfsvereniging gewezen worden. Mogelijk is dit een soort kompensatieverband: bedrijuen die de administratie en kontrole van de Ziektewet uiltbesteed hebben aan het GAK of de Bedrijfsvereniging ( $=$ sterke band) behoeven zelf namelijk niet zo"n grote personeelsafdeling te hebben. Omgekeerd moeten afdelingskassen en eigenrisicodragende bedrijven ( zwakke band) voor de administratie en kontrole van de Ziektewet in de regel wel een grotere personeelsafdeling hebben. Maer, de grootte van de personeelsafdeling is ook weer niet een puur technisch-organisatorische kwestie, want uit het model valt ook te konkluderen dat de 'management-visie' er mee te maken heeft; autoritair geleide bedrijven blijken namelijk kleinere personeelsafdelingen te hebben dan demokratisch geleide bedrijuen. ren vierde kan nog benadrukt worden dat de LISREL-analyse van faktor VII het cyclische karakter van het verzuim (Steera \& Rhodes, 1978) lijkt te bevestigen. Het lijkt er volgens het model namelijk sterk op dat het verzuim niet alleen door bedrijfssituaties beïnvloed wordt, maar zelf ook bepalde effekten heeft. Het 
gaat hierbij, zoals beschreven, met name om het ontwikkelen van een sterke of zwakke band met het GAK of de Bedrijfsvereniging, welke laatste via de grootte van de personeelsafdeling weer terugslaat op het verzuimpercentage.

\subsection{Samenvatting van hoofdstuk 7}

In dit hoofdstuk zijn 24 bedri.jfskenmerken en kenmerken van het personeelsbestand van bedrijven, te zamen met de drie verzuimmaten, geanalyseerd. De acht uit het oogpunt van betrouwbaarheid en/of validiteit minder geschikte variabelen uit de replikatieanalyse waren in deze vervolganalyse geëlimineerd. Dertien nieuwe variabelen werden aan de overgebleven elf toegevoegd.

Allereerst bleken op basis van de faktoranalyse de 24 verklarende variabelen in zeven faktoren op te delen te zijn. Deze waren (paragraef 7.2 ):

- kwaliteit van het werk en de menselijke verhoudingen;

- automatiseringsgraad van het produktieproces;

- korrelaten van verstedelijking;

- slechte financieel-ekonomische positie van het bedrijf;

- aandacht voor de individuele werknemer;

- gemiddelde leeftijd van het personeelsbestand;

- traditionele/moderne organisatie.

De samenstelling van deze zeven faktoren werd in paragraaf 7.3 besproken tegen de achtergrond van bestaende organisatie-sociologische onderzoeksliteratuur. Daarbij kwam onder meer aan de orde het zogenaamde 'technologisch imperatief', ofwel de invloed van het produktieproces op betrekkingen en verhoudingen tussen de personeelsleden. Verder werd besproken: de mogelijke kulturele beparaldheid van de organisatiestruktuur, de vraag of de financieel-ekonomische positie van een bedrijf invloed heeft op bijvoorbeeld de stijl van leidinggeven in een bedrijf of dat deze relatie andersom verloopt, de invloed van de organisatiegrootte op de persoonlijke relaties tussen mensen in bedrijuen en tenslotte de verschillen tussen traditionele en moderne organisaties.

Vervolgens werden in paragraaf 7.4 de 24 verklarende variabelen in verband gebracht met de drie verzuimmaten. De 24 variabelen blijken respektievelijk 66, 61 en 67 procent van de variantie in 
de verzuimfrekwentie, de verzuimduur en het verzuimpercentage te kunnen verklaren, hetgeen als zeer hoog aan te merken valt. In concreto zijn van de toegevoegde variabelen de volgende vijf van belang $(p<.10)$ voor het verzuimpercentage:

- hoog percentage buitenlandse produktiewerknemers $\beta=.36$

- veel kontakten over zieke werknemers $\quad \beta=.19$

- onrust in het produktieproces

$\beta=.17$

- slechte financieel-ekonomische positie bedrijf $\beta=.13$

- weinig personeelsbegeleiding en -zorg $\beta=.12$

Door middel van polynomiale regressie-analyses werd nog nagegaan of de relaties tussen de verklarende variabelen en de drie verzuimmaten beter als kromlijnige relaties beschreven kunnen worden. Dit bleek inderdaed het geval bij de relaties van onrust in het produktieproces en sociaal leiderschap met de verzuimfrekwentie, en bij de relatie van percentage buitenlandse werknemers met het verzuimpercentage.

Daarna werd in paragraaf 7.5 nagegaan of de gestelde hypothesen bevestigd konden worden. Daarbij bleek dat dit vooral bij de hypothesen ten aanzien van de zogenaamde bindingsvariabelen en de frekwentie vaak niet het geval was.

Wat betreft de verzuimduur bleek dat de begrippen afwezigheidsnoodzaak en afwezigheidsgelegenheid wel, maar het begrip aandacht voor het individuele ziektegeval niet of weinig van belang is voor de verzuimduur. Voorts bleek dat de verzuimduur vaak minstens even gevoelig voor - met name - bindingsvariabelen was als de verzuimfrekwentie. In deze $z$ in behoeft de theorie van Philipsen (1969) dus aanvulling.

In paragraaf 7.6 werd getracht enige integratie van de resultaten tot stand te brengen door na te gaan hoe sterk de relaties zijn van de zeven vermelde faktoren met de drie verzuimmaten.

Als we ons beperken tot het verzuimpercentage, dan hebben de volgende vier faktoren een betekenisvolle verhogende invloed op deze verzuimmat:

- slechte financieel-ekonomische positie van het bedrijf

$r=.45$

- slechte kwaliteit van het werk en menselijke verhoudingen

$r=.37$

- hoge automatiseringsgraad van het produktieproces

$r=.18$

- traditionele organisatie

$\Gamma=.17$ 
Tenslotte $z 1 j n$ van deze vier faktoren in paragraaf 7.7 kausale modellen opgesteld en met behulp van de analysetechniek LISREL nader onder de loupe genomen.

Twee belangrijke konklusies hieruit zijn de volgende: (a) er zijn aanwijzingen dat een, overigens verzuimbevorderende, slechte financieel-ekonomische positie van een bedrijf deels bepaald wordt door het type produktieproces (onrustig namelijk) en deels door een autoritaire en niet-instrumentele wijze van leidinggeven in het bedrijf; (b) verder zijn er aanwijzingen dat het verzuimpercentage niet alleen beinvloed wordt door bedrijfssituaties, maar daar zelf ook invloed op uitoefent. In het laatste geval gaat het om het aantal kontakten dat er in bedrijuen bestaat tussen de personeelsafdeling, de bedrijfsleiding en de verzekeringsarts over zieke werknemers en om de verzekeringsvorm die bedrijven hebben in het kader van de Ziektewet. Een hoog verzuimpercentage lijkt namelijk de keuze voor het omslaglidmaatschap en uitbesteding van administratie en kontrole te stimuleren of te versnellen, en een laag verzuimpercentage de keuze voor een afdelingskas of eigenrisikodracht voor de Ziektewet net verzuimkontrole door het bedrijf zelf. 


\subsection{Inleiding}

Deze studie kende in feite drie onderdelen. Het eerste betrof de historie van de theorievorming over ziekteverzuim. De weergave hiervan geschiedde in hoofdstuk 2. Het tweede onderdeel was een replikatie met 85 bedrijven van een eerder uitgevoerd onderzoek van Philipsen (1969) met 83 bedrijven naar de determinanten van organisatiegewijze verschillen in verzuim. Bij het replikatie-onderzoek zijn de oorspronkelijke negentien verklarende variabelen gebruikt. Het derde onderdeel tenslotte betrof een vervolganalyse met elf oorspronkelijke en dertien toegevoegde variabelen. Deze analyse vond opnieuw plaats met de vermelde 85 produktiebedrijven en had tot voornaamste doel na te gaan welke, voor de jaren tachtig aktuele, variabelen van belang zijn ter verklaring van de verschillen in ziekteverzuim tussen bedrijven.

In deze slotbeschouwing komen dezelfde drie centrale onderdelen weer terug. Ten eerste worden de praktische en theoretische implikaties van de resultaten van de analyses besproken (de paragrafen 8.2 en 8.3). Ten tweede worden de ontwikkelingen geschetst en besproken, die er in de onderzochte steekproeven van bedrijuen tussen 1964/65 en 1980/81 plaatsvonden (paragraaf 8.4). Ten derde wordt nog een aantal belangrijke resultaten van de analyses, beschreven in hoofdstuk 7, besproken (paragraaf 8.5). Hierbij gaat het niet zozeer om typisch organisatie-sociologische resultaten als wel om beleidsrelevante gegevens die betrekking hebben op arbeid en bedrijf in het algemeen (de dubbele arbeidsmarkt-theorle, de effekten van automatisering in bedrijven en de determinanten van suksesvolle bedrijuen in financieel-ekonomisch opzicht).

8.2 De voornaamste resultaten en hun praktische impli katies voor de beperking van verzuim

In de inleiding van dit boek werd vermeld dat werkgevers en werknemers nogal eens van mening verschillen, waar het gaat om het te volgen beleid op het gebied van verzuimbeperking. De eerste kate- 
gorle gaat er niet zelden van uit dat de oorzaken voornamelijk gezocht moeten worden bij de individuele werknemer, terwijl de latste kategorie meestal denkt aan bedrijfsomstandigheden en -kenmerken. Dok onder bedrijfsgeneeskundigen en personeelsfunktionarissen wordt de diskussie over de oorzaken van het verzuim regelmatig in dergelijke termen gevoerd.

Dat individuele kenmerken een oorzakelijke rol spelen in het verzuim valt niet te ontkennen (zie onder andere de literatuurstudie van Smulders, 1984). De resultaten van de in deze studie uitgevoerde analyses zet ons echter duidelijk op het spoor van de bedrijfsomstandigheden in brede zin, als het gaat om de achtergronden van het verzuim in Nederlandse industriële bedrijven. Tabel 7.6 in het vorige hoof dstuk laat nameli.jk zien dat het verzuimpercentage van de bestudeerde bedrijven door vier boven-individuele faktoren (groepen van variabelen) beheerst wordt, namelijk door een slechte financieel-ekonomische positie van het bedrijf, een slechte kwaliteit van het werk en van de menselijke verhoudingen, een hoge autamatiseringsgraad en een traditionele organisatiewijze.

Een slechte financieel-ekonomische positie van bedrijven wordt, volgens onze analyses, vooral bepaald door een autoritaire stijl van topleiderschap, door gebrekkig instrumenteel, produktie-gericht leiderschep en door onrust in het produktiepraces. De centrale invloed bij kwaliteit van het werk en de menselijke verhoudingen wordt gevormd door de vrijheid in taakuitvoering. Scholingsgraed van het werk, leiderschapsaspekten, delegatie en invloedsverschillen spelen ook een rol in deze faktor.

Bij de automatiseringsfaktor gaat het voornamelijk om ploegendienst als verzuimbevorderende invloed en rust in het produktieproces als verzuimbeperkende invloed. Daarnaast zijn delegatie en (weinig) instrumenteel leiderschap nog van belang hierbij. Het saldo van deze krachten is dat geautomatiseerde produktieprocessen een relatief hoog verzuimpercentage vertonen.

Tenslotte $\mathbb{Z} i j n$ traditionele bedrijven vaak autonoom in de bedrijfswoering met een sterke band met het GAK of de Bedrijfsvereniging en een kleine personeelsafdeling; ze worden bovendien vaak autoritair geleid en kennen relatief veel invloedsverschillen in de produktie.

Deze vier faktoren verklaren te zamen reeds ongeveer 40 procent 
van de verschillen in het verzuimpercentage tussen de bedrijven. De aloude uitspraak, dat elk bedrijf het verzuim krijgt dat het verdient, blijkt dus nog weinig van zijn aktualitelt verloren te hebben.

Genoemde vier faktoren lijken reeds voldoende aangrijpingspunten te bieden vaor managers, personeels- en medische diensten en ondernemingsraden voor het formuleren van een beleid op het gebied van het ziekteverzuim in bedrijven.

Met het oog op het verzuimbeleid kunnen we echter ook nog meer in detail kijken naar de achter de faktoren liggende variabelen. Twaalf van de 24 variabelen in de replikatie-analyse bleken signifikant $(p<.10)$ partieel met het verzuimpercentage samen te hangen. Dit zijn in volgorde van de sterkte van de bèta-koëfficiënten (zie p. 202/203):

- sterke band met GAK/Bedrijfsvereniging

$\beta=.37$

- percentage buitenlandse produktiewerknemers

$\beta=.36$

- scholingsgraad van het werk

$\beta=-.21$

- gemiddelde leeftijd produktiepersoneel

$\beta=-.21$

- autonomie in de bedrijfsvoering

$\beta=-.20$

- slechte 'naam' van het bedrijf

$\beta=.19$

- aantal kontakten over zieke werknemers

$\beta=.19$

- hinderlijke fysieke werkomstandigheden

$\beta=.17$

- bedrijf autoritair geleid

$\beta=.17$

- onrust in het produktieproces

$\beta=.17$

- slechte financieel-ekonomische positie bedrijf $\beta=.13$

- tijd besteed aan personeelsbegeleiding/-zorg $\quad \beta=-.12$

Deze twaalf variabelen verklaren $61 \%$ van de variantie in het verzuimpercentage (multipele $\mathbb{R}=.78$ ). De resterende twaalf verklaren nog slechts 7 procent van de variantle in het verzuimpercentage bij de 85 bedrijuen.

Men kan zich vervolgens de praktische vraeg stellen in welke mate de belangrijkste variabelen nu in concreto het verzuimpercentage verhogen of verlagen. Dit valt te berekenen met behulp van de regressie-koëfficiënten uit de multipele regressie-vergelijking. Bij de 85 anderzochte bedrijven in 1980/81 is het gemiddelde verzuimpercentage 11.7 procent. Nemen we nu bijvoorbeeld de belangrijkste van de vermelde twaalf variabelen, band met GAK/Bedrijfsvereniging. Een bedrijf dat op deze variabele de laagate warde heeft (dus een eigenrisicodrager die de kontrole voor de Ziektewet geheel of gedeeltelijk zelf uitvoert), heeft bij de hier on- 
derzochte bedrijven een verzuimpercentage van 1.8 procent onder het gemiddelde van 11.7 procent, terwijl een bedrijf dat op de variabele de hoogate warde heeft (een omslaglid dat de ziekenkontrole geheel uitbesteed heeft), 1.1 procent boven het gemiddelde van 11.7 procent ligt. Hierbij is ervan uitgegaan dat de andere 23 verklarende variabelen hun gemiddelde waarde hebben. Deze gegevens $z 1 j$ jn ook berekend voor de andere variabelen. Hieronder, in tabel B.l, valgen de resultaten met betrekking tot de belangrijkste twaalf variabelen voor het verzuimpercentage.

Tabel B.1 De maxtmale wersichillen met het gemiddelde verzulmpercentage bij respektievelijk de lagite en hoogstie warde op de twalf belangujijkte variabelen voor het verzulimpercentage

\begin{tabular}{|c|c|c|c|}
\hline $\begin{array}{l}\text { de belangrijkste twaalf variabelen } \\
\text { voor het verzuimpercentage }\end{array}$ & $\begin{array}{l}\text { mimimale en } \\
\text { maximale } \\
\text { empirische } \\
\text { waarden op de } \\
\text { variabelen* }\end{array}$ & \multicolumn{2}{|c|}{$\begin{array}{c}\text { maximale } \\
\text { verschillen } \\
\text { met het } \\
\text { gemiddelde } \\
\text { verzuimpercent age }\end{array}$} \\
\hline 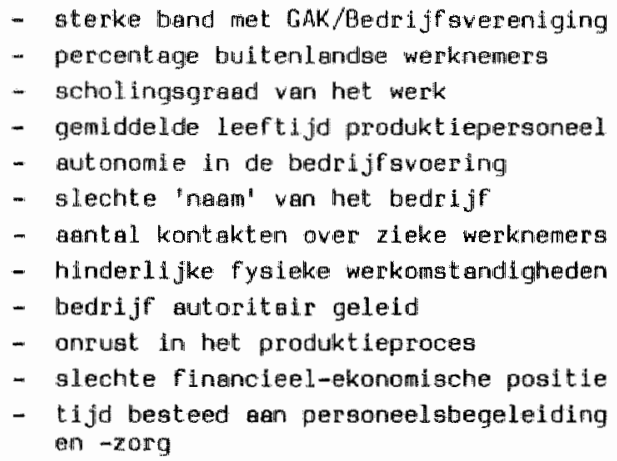 & $\begin{array}{r}2-5 \\
0-58 \\
12-30 \\
31-47 \\
3-9 \\
2-7 \\
4-9 \\
20-51 \\
1-5 \\
2-7 \\
3-10 \\
5-80\end{array}$ & $\begin{array}{l}-1.8 \\
-1.4 \\
+1.5 \\
+1.6 \\
+1.6 \\
-10.8 \\
-1.2 \\
-1.1 \\
-1.0 \\
-0.9 \\
-0.4 \\
+0.6\end{array}$ & $\begin{array}{l}+1.1 \\
+3.3 \\
-1.2 \\
-1.4 \\
-1.5 \\
+1.5 \\
+1.1 \\
+1.4 \\
+1.3 \\
+0.9 \\
+0.9 \\
-1.5\end{array}$ \\
\hline
\end{tabular}

* zle de tabellen 5.9 en 5.17 (p. $104 / 105$ en 141)

Uit deze gegevens valt dus bijvoorbeeld te zien dat een bedrijf zonder buitenlandse werknemers - als alle andere 23 variabelen een gemiddelde waarde hebben - een verzuimpercentage vertoont van 1.4 procent onder het gemiddelde verzuimpercentage van 11.7 . Twee andere voorbeelden: een bedrijf met een hoge scholingsgraad van het werk en een oud personeelsbestand zit gemiddeld 1.2 procent + 1.5 procent $=2.7$ procent onder het gemiddelde van de 85 bedrijven; ook hier wordt er weer van uitgegaan dat alle andere variabelen op hun gemiddelde score worden gehouden. 
De hierboven opgesomde 'hoogste en laagste verzuimpercentages' kunnen managers, personeels- en medische afdelingen en ondernemingsraadsleden van bedrijven een indruk geven wat het werken aan een bepaalde variabele, voor zover dat praktisch mogelijk is, voor effekten zou kunnen hebben op het verzuimpercentage.

Voorzichtigheid bij het hanteren van deze percentages is echter wel geboden, omdat ze gemiddelden zijn en niet voor elk individueel Nederlands bedrijf behoeven te gelden. Bovendien moet men bij de interpretatie van deze cijfers niet vergeten dat 'sleutelen' aan één variabele - voor zover mogelijk - tot gevolg kan hebben dat een of meer andere variabelen mede veranderen in gunstige of ongunstige zin (men zie hiervoor de interkorrelaties tussen de verklarende variabelen in tabel 7.2, p. 187). Manipulatie van één variabele kan dus op zich gunstige effekten hebben, maar tegelijkertijd 'contra-produktieve' mede-effekten door andere variabelen. Even zo goed is het uiteraard mogelijk dat manipulatie van één variabele zijn weerslag heeft, eveneens in gunstige zin, via verandering in een of meer andere variabelen.

Wellicht ten overvloede $z i j$ vermeld dat er gén bedrijven zijn die op alle punten op de meest gunstige of meest ongunstige wijze scoren. Indien dat wel het geval was geweest zou het 'gunstigste" bedrijf een verzuimpercentage van 0 en het 'ongunstigste' van minimaal zo'n 30 hebben gehad. Bij de 85 bedrijven in het onderzoek was het laagste verzuimpercentage in werkelijkheid 5.2 en het hoogste 19.1 (zie tabel 5.18, p. 145).

In het kader van de diskussie rond verzuimbestrijding dient tenslotte nog een belangrijk punt naar voren gehaald te worden. We spraken hierboven namelijk steeds over het verzuimpercentage van de bedrijven. Dit is de index die bedrijven ook meestal hanteren, als het gaat om inzicht te krijgen in hun eigen verzuimnivo. Echter, de scheiding die Philipsen (1969) reeds zo uitdrukkelijk makkte tussen de verzuimfrekwentie en de verzuimduur bli.jft, volgens deze studie, uiterst relevant.

Sommige variabelen en faktoren werken zowel in op de frekwentie als op de duur. Maar andere werken alleen in op de frekwentie of alleen op de duur.

Uit tabel 7.6 blijkt bijvoorbeeld dat de automatiseringsgraad van het bedrijf weinig of niet op de frekwentie inwerkt, maar wel heel veel op de duur. Hetzelfde geldt voor de traditionele res- 
pektievelijk moderne organisatiewijze. Voorts valt te zien dat aandacht voor de individuele werknemer en gemiddelde leeftijd van het personeelsbestand duur-bevorderend zijn, maar tegelijkertijd frekwentie-beperkend! Deze twee tegengestelde tendenties leiden er toe dat belde faktoren géén invloed uitoefenen op het verzuimpercentage.

In praktische zin betekent dit alles, dat de 'opdeling' van het verzuimpercentage in de frekwentie- en de duur-komponent extra aanwijzingen kan opleveren voor het te volgen beleid op het gebied van het verzuim.

\subsection{De gevonden resultaten in het licht van de ver- zuimtheorie}

De historie van de theorievorming rond ziekteverzuim is in hoofdstuk 2 weergegeven. Op het eind van dat hoofdstuk werd gekonkludeerd dat er een zekere mate van kanvergentie war te nemen is in de theorieën. De inhoudelijke verzuimtheorie van Philipsen (1969) werd in dit verband als vrij volledig gekenmerkt. Het onderzoek dat in deze publikatie verslagen wordt is op deze theorie gebaseerd.

Hoewel in de hoofdstukken 6 en 7 de gevonden resultaten wit de analyses reeds enigszins afgezet zijn tegen de theorie van Philipsen, is het goed dit nog eens systematisch te doen.

Allereerst kan de theorie van Philipsen samengevat worden met vier globale begrippen die geacht worden de verschillen in verzuimfrekwentie en gemiddelde duur tussen bedrijven te verklaren. Het betreft de begrippen verzuimnoodzaak, verzuimbehoefte (binding aan de werksituatie), verzuimgelegenheid (verzuimkontrole) en aandacht voor het individuele ziektegeval.

Philipsen 'operationaliseerde' deze begrippen met zijn negentien variabelen. Of de variabelen goede operationalisaties van de meer abstrakte vier begrippen zijn, valt uiteraard niet te bewijzen. Wel kan nagegaan worden welke operationalisaties (variabelen) al dan niet valide zijn voor de voorspelling van de verzuimfrekwentie en de gemiddelde verzuimduur per geval.

Wat betreft de (beperking van de) verzuimnoodzaak zijn de variabelen fysieke werkomstandigheden, gemiddelde leeftijd en percen- 
tage buitenlandse produktiewerknemers valide indikatoren gebleken voor de frekwentie of de duur.

Met betrekking tot het begrip verzuimbehoefte (binding) bleken de variabelen fysieke werkomstandigheden, scholingsgraad, delegatie, autonomie van het bedrijf, autoritaire bedrijfsleiding, percentage buitenlandse werknemers en personeelsbegeleiding/-zorg redeliljke tot goede indikatoren voor de verzuimfrekwentie te zijn. Bij het begrip verzuimgelegenheid kunnen de variabelen scholingsgraad, autonomie van het bedrijf, band met het GAK of de Bedrijfsvereniging, snelheid van de verzuimkontrole en percentage buitenlandse werknemers als goede indikatoren beschouwd worden voor het verzuim.

Tenslotte zijn bij het begrip aandacht voor het individuele ziektegeval de variabelen gunstige uitkeringsvoorwaarden, band met het GAK of de Bedrijfsvereniging en snelheid van de verzuimkontrole van belang woor de verzuimduur.

Samengevat: het is heel aannemelijk dat de vier min of meer abstrakte begrippen verzuimnoodzaak, verzuimbehoefte, verzuimgelegenheid en aandacht voor het individuele ziektegeval van belang zijn voor het begrijpen van het verzuimgedrag van werknemers. De resultaten van de onderzoeken uit 1964/65 en 1980/81 ondersteunen in globale zin dus het theoretische raamwerk van Philipsen.

Een tweede opvallend kenmerk van de theorie van Philipsen was de tamelijk strakke koppeling van de negentien variabelen aan de verzuimfrekwentie off aan de duur òf aan beide. Philipsen (1969, p. 64, 82) ging er bijvoorbeeld van uit dat de verzuimbehoefteof bindingsvariabelen alleen invloed op de verzuimfrekwentie uitoefenen en dat aandacht voor het individuele ziektegeval alleen duurbeperkende invloed zou uitoefenen.

Deze strakke koppeling nu moet op basis van de resultaten uit 1980/81 duidelijk bijgesteld worden. Overigens waren hier reeds aanwijzingen voor te vinden in de onderzoeken van Dijkstra (1977) en Ris (1978); ook uit de literatuurstudie van Smulders (1984) blijkt dat taakvariatie bijvoorbeeld duurbeperkend kan werken. Uit het onderzoek van $1980 / 81$ blijkt dat een vrij groot aantal variabelen, die geacht worden de verzuimbehoefte of de binding aan de werksituatie te indiceren, niet of niet alleen met de frekwentie maar wel of tevens met de duur samenhangen. Het betreft hier bijvoorbeeld de variabelen onrust in het produktiepro- 
ces, scholingsgraad, organisatiestruktuur en demokratische/autoritaire bedrijfsleiding.

Aan de andere kant heeft een aantal variabelen die aandacht voor het individuele ziektegeval geacht worden te indiceren, niet of niet alleen inwloed op de duur maar wel of tevens op de frekwentie. Het gaat hiler bijvoorbeeld om bedrijfsgrootte, band met het GAK of de Bedrijfsvereniging en slechte financieel-ekonomische positie van het bedrijf.

In het kader van de door Philipsen (1969; hoofdstukken 3 en 4) ontwikkelde beslissingstheorie rond ziekteverzuim betekent dit, dat de verzuimbehoefte wel degelijk ook invloed lijkt uit te oefenen op de herstelmelding en dat aandacht voor het individuele ziektegeval in het algemeen in bedrijven ook invloed lijkt uit te oefenen op het aantal ziekmeldingen dat gemiddeld ontstaat in die bedrijven. Het laatste lijkt enigszins paradoxaal, behalve als men ervan uitgaat dat aandacht voor het individuele ziektegeval samengaat met aandacht voor de individuele werknemer in het algemeen.

Als men de resultaten van de onderzoeken uit 1964/65 en 1980/81 samen in beschouwing neent ( $z$ ile de tabellen 6.7 en $6.8, p .164$, 174), dan zou men wel een aantal variabelen iets meer als typische 'frekwentie-variabelen' kunnen beschouwen en een aantal andere meer als typische "duur-variabelen". Tot de eerste kategorie zou men dan kunnen rekenen: delegatie, autonomie in de bedrijfsvoering en demokratisch/autoritair leiderschap; tot de tweede de variabele uitkeringsvoorwaarden bij ziekte. Op basis van de vervolganalyse is het waarschijnlijk dat de snelheid van de verzuimkontrole ook alleen duur-effekten heeft en geen frekwentie-effekten.

Een derde en laatste punt met betrekking tot de theorie rond verzuim betreft het feit dat verzuim niet alleen als gevolg maar ook als oorzaak gezien kan worden. Dit is reeds door Steers en Rhodes (1.978) beargumenteerd. In hoofdstuk 2 zijn ook enkele empirische onderzoekingen aangehaald waaruit te konkluderen valt dat de hoogte van het verzuim invloed kan hebben op promotiemogelijkheden, op begeleiding van zieke werknemers en op leiderschapsstijlen.

In paragraaf 7.7 van deze studie is aannemelijk gemaakt dat het verzuimpercentage van de bedrijven invloed uitoefent op het aan- 
tal kontakten in bedrijven tussen funktionarissen over zleke werknemers en op de keuze voor een sterke respektievelijk zwakke band met GAK/Bedrijfsvereniging. In het laatste geval lijkt het erop dat men zelfs van een cyclisch verband kan spreken bij de volgende drie variabelen: hoog verzuimpercentage $\rightarrow$ sterke band met GAK/Bedrijfsvereniging $\rightarrow$ relatief kleine personeelsafdeling $\rightarrow$ laag verzuimpercentage (zie figuur 7.14, p. 230). Blijkbar gaan er van verhoudingsgewijs kleine personeelsafdelingen (die men méér tegenkomt in bedrijven met een slechte "naam") verzuimbeperkende, mogelijk 'politionele' impulsen uit.

\subsection{De ontwikkelingen van 1964/65 tot $1980 / 81$}

Van negentien organisatie- en personeelskenmerken zijn in 1964/65 bij 83 produktiebedrijven en in $1980 / 81$ bij 85 produktiebedrijven de warden vastgelegd.

Hoewel de later onderzochte bedrijven - op een vijftiental na niet dezelfde zijn als de oorspronkelijke, zijn er wel duidelijke overeenkomsten tussen beide steekproeven wat de spreiding over de aspekten regio, bedrijfstak en produktieproces betreft.

Daarom kan vergelijking van beide groepen bedrijven op het punt van de negentien variabelen wel legitiem $z i j j n$. Tussen de twee onderzoeken ligt een verschil in tijd van ongeveer 15 jaar. In die tiljd is er in ons land veel veranderd. Een golf van demakratisering, medezeggenschap en humanisering van de arbeid deed zich eind jaren zestig en begin jaren zeventig voor. Het eind van de periode van 15 jaar wordt echter meer gekenmerkt door ekonomische problemen, bedrijfssluitingen, fusies, ontslagen. Er is sprake van een verandering van een groei-ekonomie in een krimp-ekonomie.

Het zou de validiteit van deze studie ondersteunen indien dit soort ontwikkelingen in de cijfer-ontwikkelingen worden teruggevonden. In paragraaf 5.3 (p. 104/105) zijn de gemiddelde waarden voor beide perioden reeds weergegeven.

De veranderingen $z i j n$ getoetst door vergelijking van deze gemiddelden, rekening houdende met de steekproefgrootten en de standaard-deviaties van de gemiddelden. Een technisch aspekt bij deze vergelijking is dat een viertal variabelen (delegatie, bedrijfsgrootte, "naam' en stedelijkheidsgraad) iets moeillijker in de 
tijd te vergelijken $z i j n$, varwege niet-identieke theoretische variatiebreedten. Bij deze variabelen moet dus wat meer terughoudendheid betracht worden wat betreft de veranderingen.

Verder dient voorzichtig omgegaan te worden met de op inter-subjektieve of subjektieve metingen berustende variabelen, als werkonstandigheden, delegatie, demokratische/autoritaire bedrijfsleiding en "naam'. Mogelijk zijn de 'referentiekaders' waaraan bij de beantwoording wan de betreffende vragen gedacht werd van 1964/ 65 tot 1980/81 veranderd. Het meest waarschijnnlijk is dat dit dan in kritische zin is gebeurd. Dit zou betekenen dat objektief ge1ijkgebleven werkomstandigheden en menselijke relaties 15 jaar later door de beoordelaars als ongunstiger gepercipieerd en gekenschetst zouden warden.

De verschillen tussen de gemiddelden zijn onderzocht met de Student T-toets (5-procentsnivo; tweezijdig). De ontwikkelingen in de tijd bij de onderzachte bedrijuen zijn de volgende (zie tabel 5.9, p. 104/105):

- grotere arbeidsintensiteit;

- meer onrust in het produktieproces;

- groter percentage ploegendienstwerknemers;

- minder hinderlijke fysieke werkomstandigheden;

- meer delegatie van verantwoordelijkheden;

- minder platte organisatiestruktuur;

- grotere bedrijfsomvang;

- minder autoritaire leiding van de bedrijven;

- meer ontwikkelde personeelsfunktie;

- meer professionele personeelsbegeleiding;

- gunstiger uitkeringsvoorwaarden bij ziekte;

- minder personeel met korte diensttijden.

Geen signifikante veranderingen zijn war te nemen bij:

- type produktieproces (mate van routinisering);

- scholingsgraad van het produktiewerk;

- autonomie in de bedrijfsvoering;

- 'naam' van het bedrijf;

- band met GAK/Bedrijfsvereniging;

- gemiddelde leeftijd van het produktiepersoneel;

- stedelijkheidsgraad van de omgeving.

Allereerst valt uit de niet-veranderde variabelen produktieprocestype en stedelijkheidsgraad op te maken dat de steekproef van bedrijuen uit $1980 / 81$ wat bedrijfstak/produktieproces en wat re- 
gio betreft inderdaad ongeveer overeenkomt met de steekproef uit $1964 / 65$.

Op basis van de signifikante veranderingen lijkt een viertal globale konklusies gewettigd. Ten eerste is er een zekere tendens naar een betere kwaliteit van werk en menselijke verhoudingen (minder hinderlijke werkomstandigheden, meer delegatie, minder autoritair leiderschap, gunstiger Ziektewetuitkeringsvoorwarden) warneembaar. Enige terughoudendheid lijkt op het eerste gezicht bij deze konklusie geboden, omdat een aantal van deze indikatoren - werkomstandigheden, delegatie en leiderschap - op inter-subjektieve metingen gebaseend zijn. Gezien echter het feit, zoals gezegd, dat de beoordelingscriteria eerder kritischer dan milder zullen zijn geworden en vermelde tendenzen in gunstige richting richting gaan, is het onwaarschijnlijk dat de betreffende omstandigheden in objektieve zin toch verslechterd zouden zi.jn.

De gesignaleerde ontwikkelingen in deze cijfers staan in schril kontrast tot wat De Sitter (1981, p. 74) opmerkt over de ontwikkelingen ten aanzien van de kwaliteit van de arbeid in fabrieken en kantoren. Hij konkludeert namelijk dat zich darrin "gedurende de afgelopen decennia" een "aanzienlijke" daling heeft afgespeeld. De Sitter doet dit ondanks het feit dat hij een gebrek aan feitelijke gegevens op dit terrein konstateert. Voor de middelgrate produktiebedrijuen, die in de onderhavige studie geanalyseerd werden, lijkt zijn konklusie in ieder geval niet op te gaan.

Een tweede konklusie is dat er een zekere professionalisering in personeelsbeleid en -beheer herkenbaar is. De personeelsfunktie is meer ontwikkeld en de personeelsbegeleiding is professioneler geworden. Dit is een nogal plausibele ontwikkeling.

Ten derde zijn er organisatorisch enige veranderingen warneembaar, als men ziet det de bedrijven in struktuur uitgewerkter (steiler) zijn geworden en er meer in ploegendienst wordt gewerkt dan voorheen. In deze veranderingen is een zekere mate wan modernisering van management waar te nemen en een effektiever gebruik van de produktiemiddelen. Mogelijk is ook dat het méer werken in ploegendienst de bedrijuen ertoe gedwangen heeft een extra laag leidingqevenden an te stellen, bijwoorbeeld voor superwisie buiten de dag-uren.

Ten vierde zouden ekonomische problemen de achtergrond kunnen zijn van de grotere onrust in het produktieproces en het feit dat 
het personeel langere diensttijden vertoont. Het laatste zou te maken kunnen hebben met de geringere mobiliteit op de arbeidsmarkt in 1980/81 en daaraan voorafgaande jaren.

De grotere omvang van de bedrijven in $1980 / 81$ is geen 'autonome' ontwikkeling, maar heeft te maken met het feit dat in 1980/81 grotere bedrijuen tot de steekproef zijn toegelaten.

\subsection{Enige verdere beleidsrelevante resultaten uit de} faktoranalyse

De 24 verklarende variabelen uit de vervalganalyse zijn in hoofdstuk 7 gefaktoranalyseerd. Dit leverde zeven faktoren op, die in paragraaf 7.3 ook beaproken werden tegen de achtergrond van eerdere organisatie-sociologische theorie en onderzoek. In deze slotbeschouwing zullen drie van deze faktoren nog nader besproken worden. Het gaat hier niet zo zeer om typisch organisatie-sociologische resultaten, maar meer om beleidsrelevante gegevens op het gebied van arbeid en bedrijf in het algemeen.

De eerste gevonden faktor bevatte een tiental variabelen die met de kwaliteit van het werk en de menselijke verhoudingen samenhangen. Gekonkludeerd werd dat op deze faktor zowel technologie- of taak- als organisatiestrukturele variabelen laden. Als gunstig te beschouwen taakaspekten (hoge scholingsgraad van het werk en veel autonomie) blijken samen te gaan met als gunstig te beschouwen menselijke verhoudingen (delegatie, demokratisch en sociaal leiderschap, etcetera). Deze faktor is interessant vanuit de zogenaamde 'dubbele arbeidsmarkttheorie' (zie bijvoorbeeld Kalleberg \& Sørensen, 1.979), welke veronderstelt dat er een tendens bestaat dat de arbeidsmarkt in twee te onderscheiden segmenten verdeeld is, wartussen weinig of geen mobiliteit bestaat. Aan de ene kant zouden zich de goede banen en aan de andere kant de slechte banen bevinden. In deze dubbele arbeidsmarkttheorie gaat het dus niet om goede en slechte opleiding, maar om de beschikbaarheid van goede en slechte funkties. Het eerste segment zou ook gekenmerkt worden door stabiliteit, goede beloningen en mogelijkheden om vooruit te kamen; het tweede segment zou deze kenmerken niet of in veel mindere mate hebben. In het eerste segment zouden zich ook de grotere kapitaalintensieve bedrijven bevinden. Verscheidene auteurs hebben, onder andere op basis van empirisch 
onderzoek, beargumenteerd dat de theorie analytische waarde heeft, maar de complexiteit van de ekonomie in de hoog-ontwikkelde landen toch simplificeert.

De gegevens uit het onderzoek uit $1980 / 81$ (faktor I) laten nu zien dat bedrijven met relatief goede banen inderdaad ook gekenmerkt worden door goede menselijke verhoudingen en andere bijkomende positieve omstandigheden. Bedrijuen met laaggeschoold werk, daarentegen, blijken ook laag te scoren op vrijheid in het werk, demokratisch en sociaal leiderschap, etcetera. Dit soort bedrijven makt relatief veel gebruik van buitenlandse produktiewerknemers.

Faktor I lijkt, met andere woorden, aan te tonen dat er inderdaad segmenten bestaen in de arbeidsmarkt in de Nederlandse industrie, hoewel de opdeling waarschijnlijk meer in graduele zin opgevat moet worden en niet zo zeer als een dualiteit gezien moet worden.

Faktor II in de faktoranalyse werd automatiseringsgraad van het produktieproces genoemd. De bedrijven die hier het hoogst op scoorden waren die met rustige produktieprocessen, zonder veel storingen en met veel ploegendienst.

In concreto waren dit chemische bedrijven (aluminium, weefsels, kunstmest), voedselverwerkende bedrijven (meel, zetmeel, chocola), enkele metaalbedrijven, een drukkerij en een cementproducerend bedrijf. Dit zijn tevems de lets grotere bedrijven waarin relatief veel delegatie van verantwoordelijkheden plaatsvindt. Volgens de faktoranalyse zouden deze bedrijven ook gekenmerkt worden door een iets lager opleidingsnivo en een iets lagere graad van instrumentele, produktie-gerichte leiderschapsstijl. Nadere analyse leert echter dat de hoofdvariabele uit deze faktor (onrust in het produktieproces) kromlijnige verbanden vertoont met delegatie en scholing (U-relaties) en instrumenteel leiderschap (omgekeerde U-relatie).

Deze gegevens zijn van belang in de diskussie rond de al dan niet veronderstelde positieve effekten van automatisering in de industrie op de kwaliteit van de arbeid. Blauner (1964, p. 182) stelde op basis van zijn onderzoekingen dat er een ongekeerde U-relatie bestaat tussen produktieprocestype en vervreending. Enkelstuksproduktie en procesproduktie zouden de minste vervreemding onder werknemers opleveren en serie- en massaproduktie de meeste. Woodward (1958, 1965) komt tot een gelijksoortige konklusie. Aan de 
andere kant staan Kern en Schumann (1970) die menen dat automatisering alleen voor sommige werknemers gunstige effekten heeft en voor andere juist ongunstige, in termen van kwaliteit wan het werk.

Faktor II uit de vervolganalyse laat nu dus zien dat bedrijven met geautomatiseerde, rustige produktieprocessen zich ten aanzien van de kwaliteit van het werk gemiddeld gunstig onderscheiden van de serie- en massaproduktieprocessen en zich op dit punt op ongeveer hetzelfde nivo bevinden als de onrustige enkelstuksproduktieprocessen.

Vertaald in termen van verzuim, blijkt uit de tabellen 7.6 en figuur 7.6 ( $p .212$ en 216) dat geautomatiseerde produktieprocessen gekenmerkt worden door een lagere verzuimfrekwentie, maar ook door langere gemiddelde verzuimduren per geval (onder andere door de ploegendienst en de lage graad van instrumenteel leiderschap) waardoor een relatief hoog verzuimpercentage het saldo is.

Tenslotte verdient faktor IV uit de faktoranalyse van hoofdstuk 7 hier nog nader besproken te worden. Deze faktor had als centale variabele de financieel-ekonomische positie van de bedrijven. Uit de LISREL-analyse (paragraaf 7.7) bleek dat een goede financieel-ekonomische positie waarschiljnlijk wordt bepaald door een demokratische stijl van leidinggeven, een hoge mate van instrumenteel, produktie-gericht leiderschap en door rust in het produktieproces. Ook de buiten deze faktor vallende variabele delegatie van verantwoordelijktheden aan niet-leidinggevenden blijkt samen te gaan met een goede financieel-ekonomische positie van de bedrijuen (zie tabel 7.1, p. 184).

In de literatuur over arbeid en organisatie van de laatste tien jaar is veel belangstelling geweest voor de invloed van de mate van centralisatie van bedrijven op hun ekonomische effektiviteit. Negandhi en Reimann (1973), Boseman en Jones (1974) en Pennings (1976) kwamen allen tot de konklusie dat decentralisatie en participatie de ekonomische effektiviteit ten goede komen.

Als we delegatie en demokratisch leiderschap opvatten als kenmerken van een gedecentraliseerde organisatiestijl, dan onderschrijven de resultaten van deze studie dus de algemene konklusie van genoemde auteurs dat decentralisatie een gunstige voorwarde is voor de financieel-ekonomische effektiviteit van organisaties. Reeds eerder hebben we kunnen vaststellen dat een goede kwaliteit 
van de arbeid het ziekteverzuim laag houdt. Hier kunnen we nu aan toevoegen dat een goede kwaliteit van de menselijke relaties in het bedrijf de produktiviteit ten goede komt. 
This doctoral dissertation deals with sickness absenteeism in three different ways. First, theoretical models and trends are reviewed (chapter 2). Second, a replication of a study by Philipsen (1969), carried out in 1964/65 with nineteen organizational variables in 83 Dutch industrial firms is described. The replication was done in 1980/81 with the same variables in 85 industrial organizations. The purpose of this replication is to find out to what extent both analyses lead to the same or different results. Information on the research samples, methods, variables used and results are given in chapters 3,5 and 6 . Chepter 4 discusses levels of analysis, since results in this study are based on characteristics of organizations, rather than on traits of individual employees. The third part of this book (chapter 7) is an extension of the above-mentioned replication. In this analysis thirteen new variables, important for the years 1980/81, are added to the eleven most reliable and valid variables from the replication analysis. The purpose of this follow-up analysis is to find out what the main variables are that explain differences in absenteeism between the 85 industrial firms in 1980/81. Final$l y$, chapter 8 recapitulates and discusses the main results of this dissertation.

The above mentioned three parts will be summarized below. As far as theoretical models and trends are concerned, it is ascertained that research on absenteeism in the fifties and sixties has followed very simple theoretical lines. In the beginning (often in later periods too) absenteeism simply has been viewed as an effect of job dissatisfaction, lack of work or job involvement, lack of work motivation, etc. These concepts all indicate something of the relationship between the employee and his or her work situation or work organization. It is concluded that these concepts may explain differences in absenteeism between employees, but mostly to a limited extent.

Further, some more general organizational theories, which have been used to explain absenteeism in industry are presented. None of these theories were constructed with the aim of explaining absenteeism, although this dependent variable very often is in- 
in research with these theories. Here exchange theory, equity theory, expectancy theory, role theories, leadership theories and task-related theories are discussed.

The first three theories are process theories, while the last three are more content-directed. It is not clear, because of lack of enough empirical support, which of the three process theories explain absenteeism best. On the other hand, there is empirical evidence that role problems, leadership and task characteristics all are important for explaining differences in absenteeism between employees or organizations.

In the fifties and sixties in the US and Great Britain some first attempts were undertaken to construct models especially directed to explain absence in industry. In these theories the relation between the employee and his organization was usually seen as an exchange-relation. Within this context some authors are interested in the 'socialization' of the individual into the organization. New in these models is, that different forces are distinguished in relation to absence behaviour: positive and negative sanctions on the individual making him or her staying with the organization, forces on the individual that compel him or her to be absent (health, family, transport), and also individual orientations of employees, which make them susceptible to the abovementioned forces.

Finally, some more comprehensive Dutch and Anglo-Saxon models to explain absenteeism are presented. Concepts as job satisfaction or attachment to work, positive and negative sanctions, the nonwork situation, personal characteristics and individual values are all included in some form in these models. On the other hand, there exists far more interest in Dutch models for health and health problems than in Anglo-Saxon models. The cyclical character of absence has only been emphasized by Steers and Rhodes (1978). It is concluded that these models show an increasing convergence as far as possible factors determining absence behaviour are concerned.

The empirical part of this dissertation is based on one of the more comprehensive theories (Philipsen, 1969). This author tested his theory with 19 variables, collected in 83 Dutch firms in $1964 / 65$. These plants (far the greater part from the metal, food processing, textile and chemical industry) provided work for be- 
tween 120 and 960 employees, and were spread over all the regions of The Netherlands.

This study was replicated in 1980/81 with the same nineteen variables, which were collected in 85 industrial organizations. These plants were sonewhat larger than the original plants, but spread almost in the same way over the Dutch regions and the branches of industry as in the 1964/65-study.

The absence measures used are the same as in 1964/65: the mean frequency per employee, the average duration per spell and thirdIy the absence rate (days absent per 100 days), which is the product of frequency and duration per spell.

Two conclusions may be mentioned. First, by way of factor analysis, it is established that four of the five factors Philipsen (1969) found in his material, are also found in 1980/81. These factors are: the extent to which the production process is routinized, the extent to which the firm is able to recruit personnel easily, the degree of urbanization of the environment of the firm and the degree to which the firm is traditionally or modernly organized.

Second, as far as the absence rate is concerned it is concluded that fourteen variables do not differ significantly in their relations with the absence rate over both periods. Of these fourteen variables nine can be identified as absence-inducing forces (the mean partial correlation in parentheses):

- a low degree of routinization of the production process

- hindrance of physical working conditions

$$
\begin{aligned}
& (r=.14) \\
& (r=.23) \\
& (r=.17) \\
& (r=.18) \\
& (r=.19) \\
& (r=.21) \\
& (r=.37) \\
& (r=.19) \\
& (r=.16)
\end{aligned}
$$$$
\text { a low degree of autonomy of the firm }
$$$$
\text { a high degree of flatness of the organizational }
$$$$
\text { structure }
$$$$
\text { authoritarian leadership }
$$$$
\text { unfavourable sickness benefits }
$$

a low own risk for the firm itself as far as its absence level is concerned, together with absence control done by an outside-agency

- many employees with short tenure

The other five variables may be considered as having no relation with the absence rate of the firms (the mean partial correlation in parentheses): 
- the labour-intensity of the firm

$$
\begin{aligned}
& (r=.06) \\
& (r=.04) \\
& (r=-.05) \\
& (r=-.04) \\
& (r=.10)
\end{aligned}
$$

unrest in the production process employees

department

- protessional personnel-guidance

The remaining five variables show inconsistent relationships with the absence rate over the two periods under study. These are:

- percentage shift workers per firm

- skill level of the production work

- personnel number of the firm

- unfavourable reputation of the firm

- mean age of the production personnel $(r=.02$ and .31$)$

$(\mathrm{r}=-.05$ and -.37$)$

$(r=-.26$ and .20$)$

$(r=.05$ and .36$)$

$(\mathrm{r}=.29$ and -.25 )

With respect to the other two dependent variables (absence frequency and average duration per spell), the same comparative analyses are carried out.

All in all, it is concluded that 74 percent of the nineteen original partial relations with the absence rate can be confirmed in the replication analysis. For absence frequency this confirmation-percentage is 63 and for average duration per spell it is 74.

The nineteen variables together explain 61 percent of the variance in the absence rate in the 1980/81-study. This percentage was 48 in the 1964/65-study. Both high percentages imply that the variables chosen for the studies may be considered as very relevant for explaining differences in absence rates of industrial organizations.

The third part of the dissertation deals with a follow-up analysis. Therefore eleven variables of the replication study are retained and thirteen new variables are added.

of the thirteen variables added five turn out to be important for explaining the differences in the absence rates between the firms:

- high percentage of foreign employees

$(\beta=.36)$

- number of contacts between management, the personnel department and the insurance doctor

$(\beta=.19)$ about absent workers

- unrest in the production process (a new version of the earlier variable)

$(\beta=.17)$ 
- unfavourable financial-economic position of the firm

- Low degree of guidance and care for the personnel $(\beta=.12)$ The 24 variables in this follow-up analysis are factor-analyzed and it turns out that they may be grouped into seven factors. of these seven factors the following four are significantly associated with the absence rate of the firms:

- unfavourable financial-economical position of the firm

$(r=.45)$

unfavourable quality of work and inter-personal relations

$(r=.37)$

high degree of automatization of the production process

- a traditional rather than a modern way of
organization

- a traditional rather than a modern way of
organization

$(r=.17)$

The relations of the four factors - and especially of the first two - with the absence rate may be considered as the main results of the whole study.

For the variables within these four factors causal models are constructed and tested with the help of the statistical technique LISREL.

The results of the replication as well as the follow-up analysis are discussed in the light of Philipsen's absence theory. The general conclusion is that the concepts in his theory (absence necessity, instrumental and social attachment of the employee to the work situation, social and economical absence control, attention for the individual absent employee) all may be considered as relevant for explaining differences in absence frequency and absence duration between organizations. In addition, it may be concluded that the attachment variables are less important for absence frequency than was hypothesized by Philipsen. The same is true for the variables under the concept attention for the individual absent employee in relation to absence duration. Finally, it is concluded that attachment to the work situation is not only of importance for explaining absence frequency - as Philipsen hypothesized - but also for explaining absence duration.

Since information is available on nineteen variables from the $1964 / 65$ - as well as the $1980 / 81$-study, it is possible to uncover the developments which took place in Dutch industry between these two points in time. 
In this way, it is ascertained that quality of work and human relations have been improved, that personnel-work has been professionalized and that the organizations have become taller and have gone working more in shift systems.

In addition, economical problems may be the background of the higher degree of unrest in the production departments in 1980/81 in comperison with $1964 / 65$. 

BI JLAGEN

I Gemiddelde en spreiding van de subvariabelen behorende bij de 32 verklarende variabelen (onderzoek 1980/81)

II Het aantal items per variabele, de informatiebron(nen) per variabele en de meeteenheid warnar de variabele verwijst (onderzoek 1980/81)

III Matrix van de interkorrelaties tussen de verklarende variabelen; de nulde orde en de partiële korrelaties van de $17 \mathrm{e}$ orde (onderzoek 1964/65)

IV Uitkomsten van de faktor-analyse van de verklarende variabelen; ongeroteerde en geroteerde ladingen (onderzoek 1964/65) 
Bijlage I Gemiddelde en spreiding var de subvariabelen behorende bij de 32 verklaberde vallabelen (onderzoek $1980 / 91 ; n=85$ )

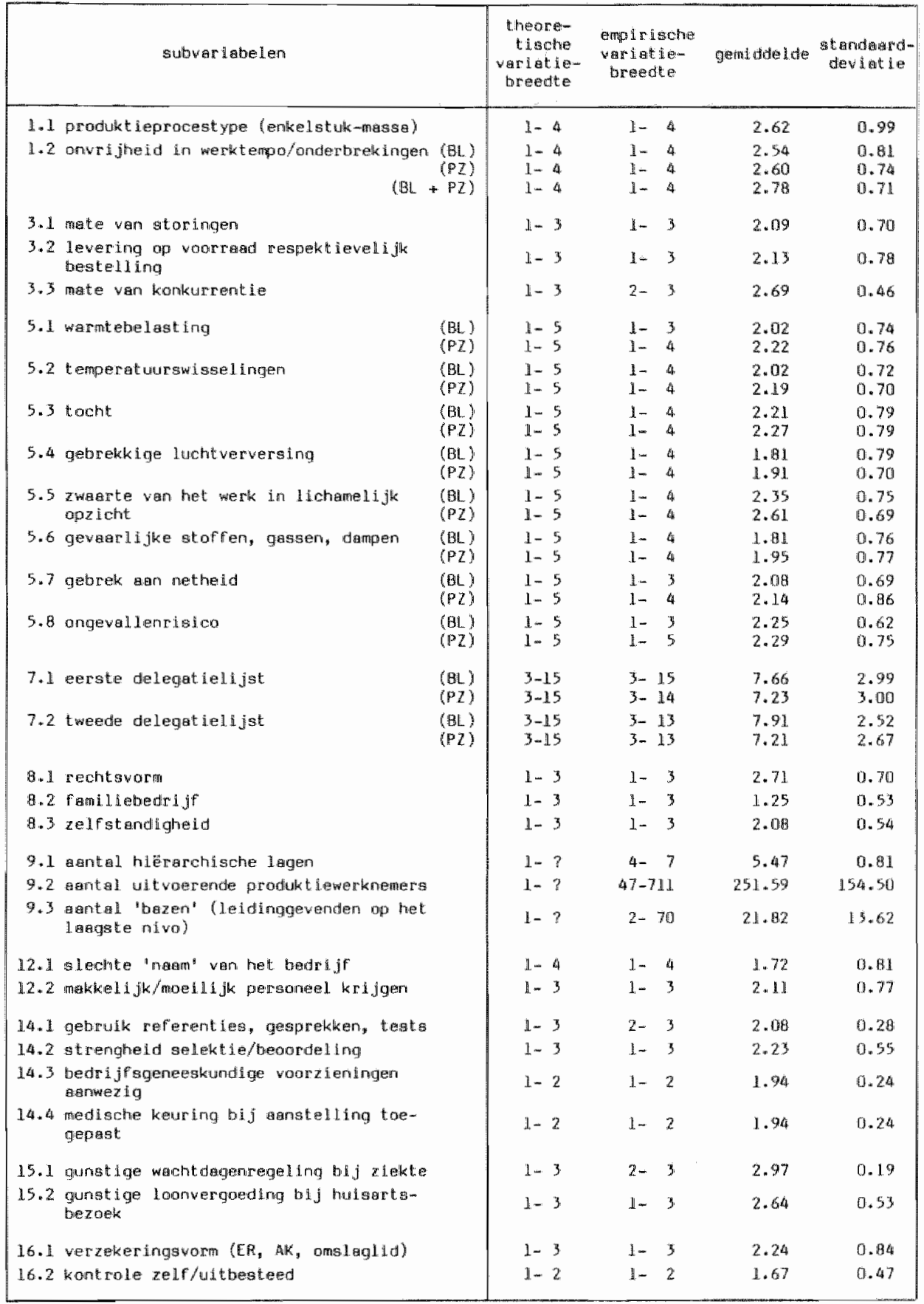

BL = informatie wan bedrijfaletder $/ P Z$ = informatle van hoof personetwaker 


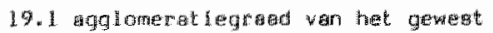

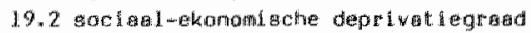
gewes

20.1 produkt leproced ype (proces-endelatuk)

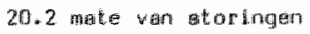

21. I writhed in werk temp/onde rbek ringen $2 \mathrm{~L} .2$ duur van de arbeldacyclus:

22.1 a日ntal ut twoerende produkt tewerkneners

22.2 arrel tbazen" (leddfrgqevenden op het loagste nivol

23.1 omvang tot ale personeelsbestand

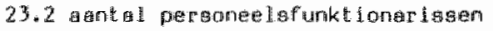

24.1 th jo besteed man saciale begelelding 24.2 tijd begteed mart puersoneelazorg

25.1 omzet en orderpositie (goed - slecht)

25.2 peranelsatop

25.3 fzetproblemen

20.1 knatakten DL met PZ over zieke werk nemers

29.2 kont whten $P Z$ met. BL over zielke werknemiera

28.3 kont actem $P Z$ met warzekerirgadrts over ziekw werknemer's

29.1 totale antal produkt lewertomenes (inclusief technische dienat)

29.2 atantal bultenlandse produkt lewerknemerss (mamnen en wouwen)

30.1 baas sitelt mensen op gemak

30.2 bass geeft ulting san wardering:

30. I bass is wriendelijik en stant open

\$1.1 heas atad op vastagestelde regals

11.2. baks gpoort langreme werkers an

31.3 bage lot op beat dow

32.1 wertempo uitwosende prothkt lemedem werke $1^{2} 8$

32.2 werkmethoden uitworende produth iemedewerkers

32.3 verui ewwen gereedschap ultwoerende produkt lemedemerkers

32.4 bevardering ut werendie produkt ienedewerkers

32.5 vrlje dagem krijgen witwoerende produk ti enedrawerkerg

\begin{tabular}{|c|c|c|c|}
\hline$d-4$ & $1-4$ & 2.69 & 0.93 \\
\hline $1-3$ & $1-3$ & 1.59 & 0.85 \\
\hline $10=4$ & 1. 4 & 2.42 & 0.94 \\
\hline $1-3$ & $1-3$ & 2.09 & 0.70 \\
\hline $1-4$ & $1-4$ & 2.22 & 0.71 \\
\hline $1-4$ & 1. 4 & 3.13 & 0.99 \\
\hline $1-?$ & $47-711$ & 2511.59 & 154.50 \\
\hline $1-?$ & $2-70$ & 21.82 & 1.3. 6.2 \\
\hline $100-1200$ & $166-1571$ & 484.32 & 281.13 \\
\hline $0-?$ & $1-15$ & 4.67 & 3.38 \\
\hline 0-100\% & $2-40 \%$ & $16.54 \%$ & Q. B. B\% \\
\hline $0-100 \%$ & $0-40 \%$ & $8.58 \%$ & $6.75 \%$ \\
\hline $1=4$ & $1-4$ & 1.64 & 0.80 \\
\hline $1-3$ & $1-3$ & 1.79 & 0.91 \\
\hline $1-3$ & $1-3$ & 1.68 & 0.93 \\
\hline $1-3$ & $1-3$ & 2.38 & 0.60 \\
\hline $1-3$ & $1-3$ & 2.28 & 0.61 \\
\hline $1-3$ & $1-3$ & 2.06 & 0.73 \\
\hline $1-?$ & $53-1050$ & 318.97 & 197.199 \\
\hline a-? & $0-304$ & 55.62 & 57.07 \\
\hline $\begin{array}{l}1-3 \\
1-3\end{array}$ & $\begin{array}{l}1-3 \\
1-3\end{array}$ & $\begin{array}{l}2.73 \\
2.49\end{array}$ & $\begin{array}{l}0.47 \\
0.57\end{array}$ \\
\hline $\begin{array}{l}1-3 \\
1-3\end{array}$ & $\begin{array}{l}1-3 \\
1-3\end{array}$ & $\begin{array}{l}2.21 \\
2.08\end{array}$ & $\begin{array}{l}0.51 \\
0.52\end{array}$ \\
\hline $1-3$ & $2-3$ & 2.56 & 0.50 \\
\hline $1-3$ & $1-3$ & 2.40 & 0.62 \\
\hline $1=3$ & $1-$ & 2.39 & 0.58 \\
\hline $1-3$ & $1-3$ & 2.46 & 0.61 \\
\hline $1-3$ & $1-$ & 2.38 & 0.53 \\
\hline $1-3$ & $1-3$ & 2.39 & 0.51 \\
\hline $\begin{array}{l}1-3 \\
1-3\end{array}$ & $1-3$ & $\begin{array}{l}2.33 \\
2.36\end{array}$ & $\begin{array}{l}0.52 \\
0.53\end{array}$ \\
\hline $\begin{array}{l}(-3)-9 \\
(-3)-9\end{array}$ & $\begin{array}{l}(-1)-8 \\
(-11)-8\end{array}$ & $\begin{array}{l}3.31 \\
3.66\end{array}$ & $\begin{array}{l}1.75 \\
2.02\end{array}$ \\
\hline $\begin{array}{l}(-3)-9 \\
(-3)-9\end{array}$ & $\begin{array}{l}1-\theta \\
0-\end{array}$ & $\begin{array}{l}4.13 \\
4.44\end{array}$ & $\begin{array}{l}1.511 \\
1.67\end{array}$ \\
\hline $\begin{array}{l}(-3)-9 \\
(-3)-9\end{array}$ & $\begin{array}{ll}0= & 7 \\
0- & 7\end{array}$ & $\begin{array}{l}3.71 \\
4.20\end{array}$ & $\begin{array}{l}1.63 \\
1.59\end{array}$ \\
\hline $\begin{array}{l}(-3)-9 \\
(-3)=9\end{array}$ & $\begin{array}{ll}2- & 8 \\
0- & \theta\end{array}$ & $\begin{array}{l}5.60 \\
5.52\end{array}$ & $\begin{array}{l}1.42 \\
1.59\end{array}$ \\
\hline $\begin{array}{l}(-3)-9 \\
(-3)-9\end{array}$ & $\begin{array}{r}(-2)-9 \\
0-\quad 8\end{array}$ & $\begin{array}{l}3.32 \\
3.71\end{array}$ & $\begin{array}{l}1.98 \\
1.79\end{array}$ \\
\hline
\end{tabular}


Bijlage II Het antal items per variabele, de hnformatiebron(nen) per warlabele en de meteenheid weamear de varibele verwijst (onderzoek 1980/81)

\begin{tabular}{|c|c|c|c|c|}
\hline & de 32 verklarende variabelen & $\begin{array}{c}\text { ant al } \\
\text { items per } \\
\text { war i abele }\end{array}$ & $\begin{array}{l}\text { informatic- } \\
\text { bron* }\end{array}$ & meet- \\
\hline 1 & $\begin{array}{l}\text { technologisch gebonden produkt ieproces (routini- } \\
\text { sering) }\end{array}$ & 2 & $B H / P Z$ & p \\
\hline 2 & arbeldsintensiteil arganisat ie & 1 & 0 & T \\
\hline 3 & anrust in het produktieproces & 3 & $B L$ & $\mathbb{P}$ \\
\hline 4 & percentage produkt iewerknemers in ploegendienst & 1 & 0 & $p$ \\
\hline 5 & hinderlijke fysieke werkanstandigheden & 8 & $\mathrm{BL} / \mathrm{PZ}$ & $\mathrm{p}$ \\
\hline 6 & setho lingsopaded produkt i emerk & $\AA$ & D & $\mathrm{p}$ \\
\hline 7 & delegatie an niet-leidinggewenden & 2 & BL. $/ P Z$ & $p$ \\
\hline 8 & autonomie in de bedrijiswoering & 3 & D & T \\
\hline 9 & $\begin{array}{l}\text { niet-uitgewerkte organisatiestruktuur (plat- } \\
\text { heidsgraad) }\end{array}$ & 3 & 0 & $p$ \\
\hline 10 & bedrijfsgroot te & 1 & $D$ & $\mathrm{~T}$ \\
\hline 11 & bedriff auturiteir geleid & 1 & 1 & r \\
\hline 12 & $\begin{array}{l}\text { Sillechte "naam" van het bedrijf (erbeidsmerkt- } \\
\text { positie) }\end{array}$ & 2 & SL. & $\mathrm{T}$ \\
\hline 13 & ontwikeling gecsonee is funkt ie & 1 & $\mathrm{D}$ & $T$ \\
\hline 14 & professionele per soneelsbegeleiding & 4 & $P Z$ & r \\
\hline 15 & gunstige uitker ingswoorwarden bij ziekte & 2 & $\mathrm{D}$ & $\mathrm{r}$ \\
\hline 16 & sterke band mett GAk/Bedrl jf svereniging & 2 & 0 & $\mathrm{r}$ \\
\hline 17 & gemiddelde leeftijd van het produkt lepersoneel & 1 & 0 & $p$ \\
\hline 18 & $\begin{array}{l}\text { Percentage produktiewerknemers kanter dan l jear } \\
\text { in diensl }\end{array}$ & 1 & $\mathrm{D}$ & $\mathbb{P}$ \\
\hline 19 & $\begin{array}{l}\text { stedelijkheidagraad wan thet gewest warinn het } \\
\text { bedrijf ligt }\end{array}$ & 2 & $\mathrm{CBS}$ & T \\
\hline 20 & onrust in het produktieproces (nieuwe veraie) & $--\frac{-1}{2}$ & BL & $\bar{p}$ \\
\hline 21 & wijheld in taakult voering in de produkt ieselktor & 2 & $B L / P Z$ & P \\
\hline 22 & grootte van de groepen in de produlkt ie & 1 & D & $P$ \\
\hline 23 & Telatieve grootte personeelsaf deling & 1 & D & $\mathrm{T}$ \\
\hline 24 & ti.jd besteed an personeelsbegelelding en -zorg & 2 & $P Z$ & $\mathbb{1}$ \\
\hline 25 & $\begin{array}{l}\text { slechte financieel-ekonomische positie vam het } \\
\text { bedriff }\end{array}$ & 3 & BL & 1 \\
\hline 26 & $\begin{array}{l}\text { werkloosheidspercentage van liet rayon war in het } \\
\text { bedrijf liqt. }\end{array}$ & $\mathbb{1}$ & $50 \%$ & 1 \\
\hline 27 & Gnelthelo wan de verzuinkont fole & 1 & $p 2$ & Ti \\
\hline $2 B$ & eantal kontakten ower zikke werknemers & 3 & $\mathrm{BL} / \mathrm{PZ}$ & T \\
\hline 29 & percentage but talandse produkt lewerknemera & 1 & 0 & P \\
\hline 30 & soctaal le derschap & 3 & $\mathrm{BL} / \mathrm{PZ}$ & P \\
\hline 31 & Inst rument eel leiderschap & 3 & $B \mathrm{~L} / \mathrm{PZ}$ & $p$ \\
\hline 32 & 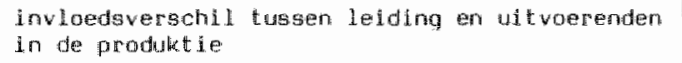 & 5 & BL. $/ P Z$ & $\mathrm{P}$ \\
\hline
\end{tabular}

* PZ = hoofd personeelisaken (min of megr sibjekt leve mening)

BL = bedrijfslulder (min of meet subjektieve mening)

D = dokumentatiegegevens (meestal verkxegen wa da personeelardalling)

$1=$ interviewerg observat le

ICBS = Contragl Bureau voof de 5 tatistiek

SoZa = Ministerle wan Son 1 ale Zaken en Werkgelegenhe io

* $T$ = totale organisatio als meteenheld

p = produkl hesektor als meetenheid 


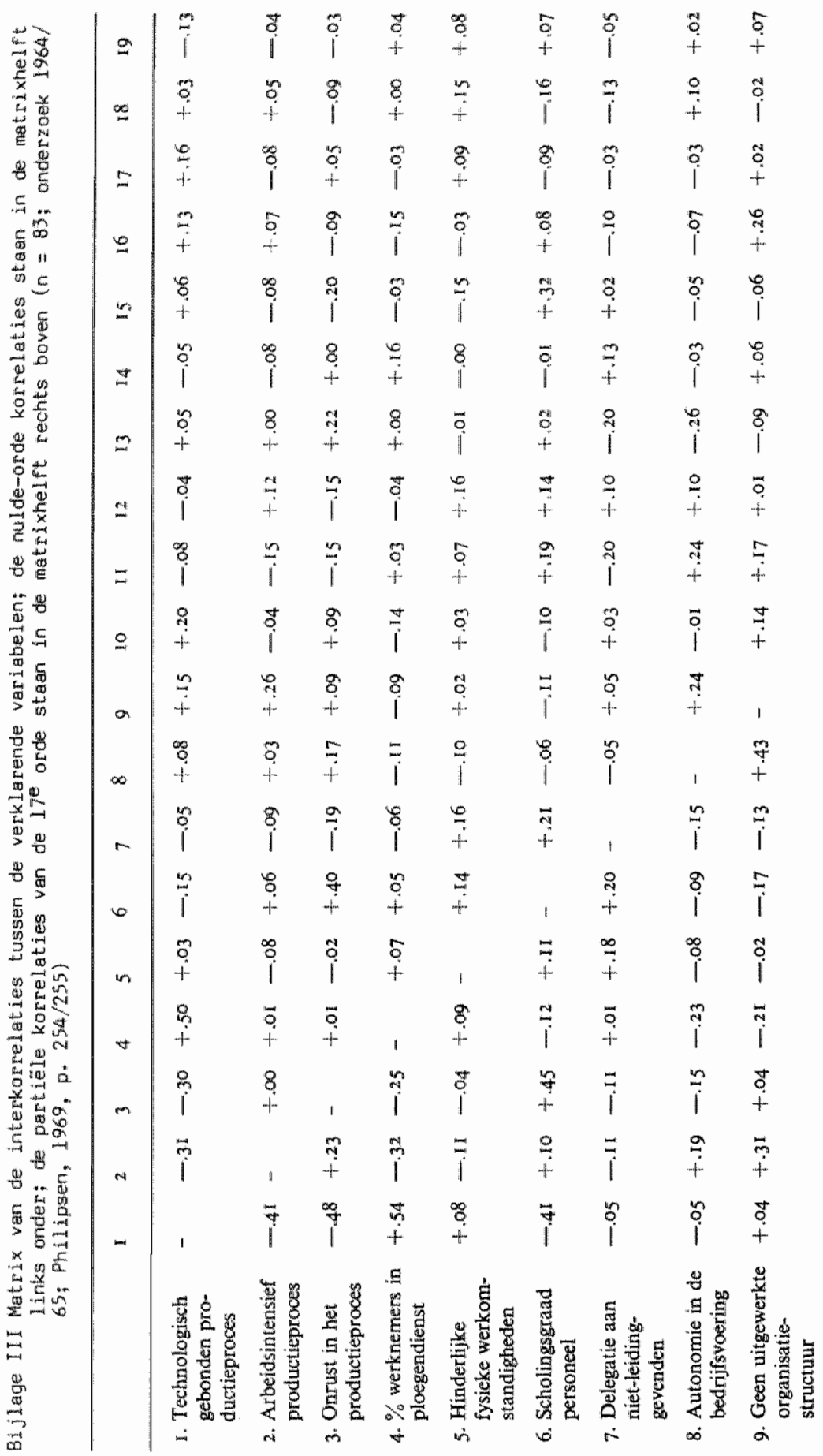




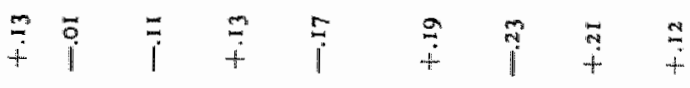

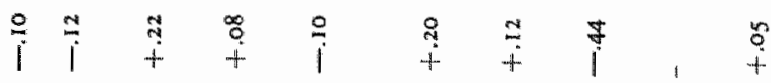

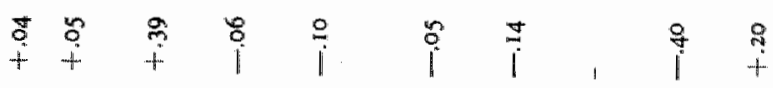

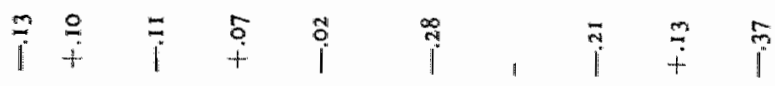

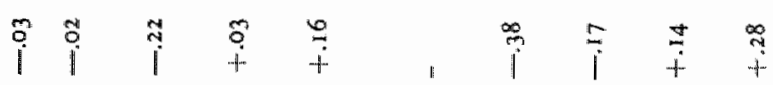

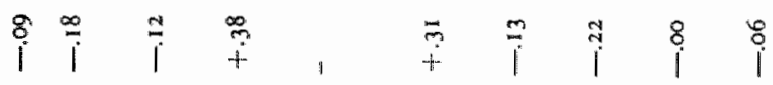

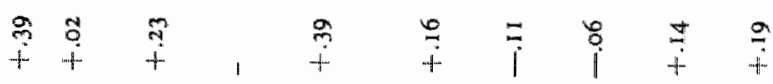

番贲,

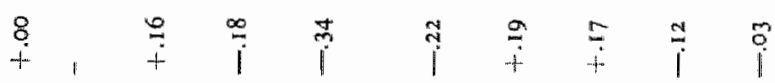

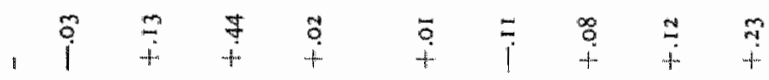

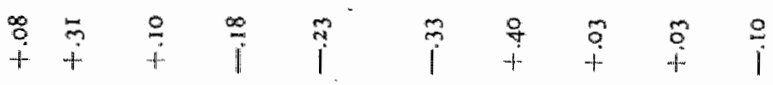

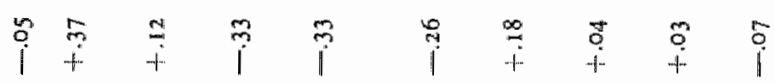

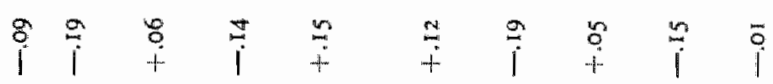

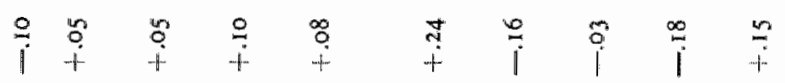

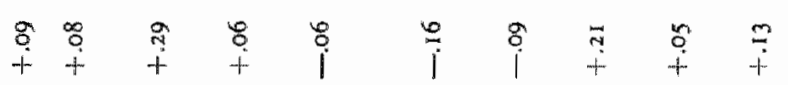

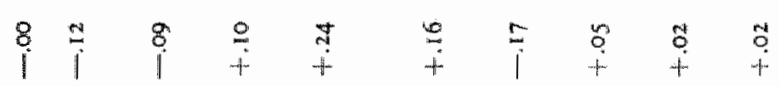

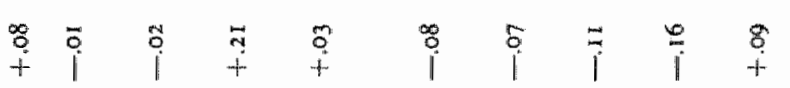

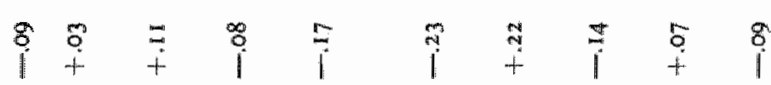

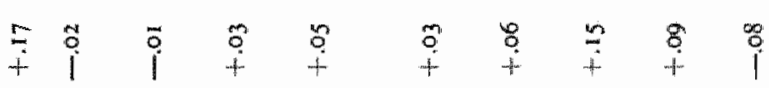

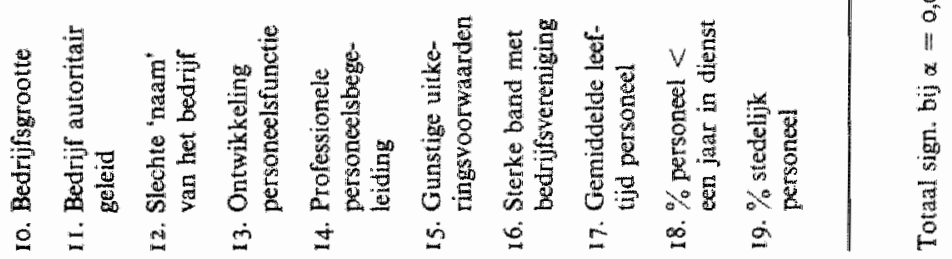




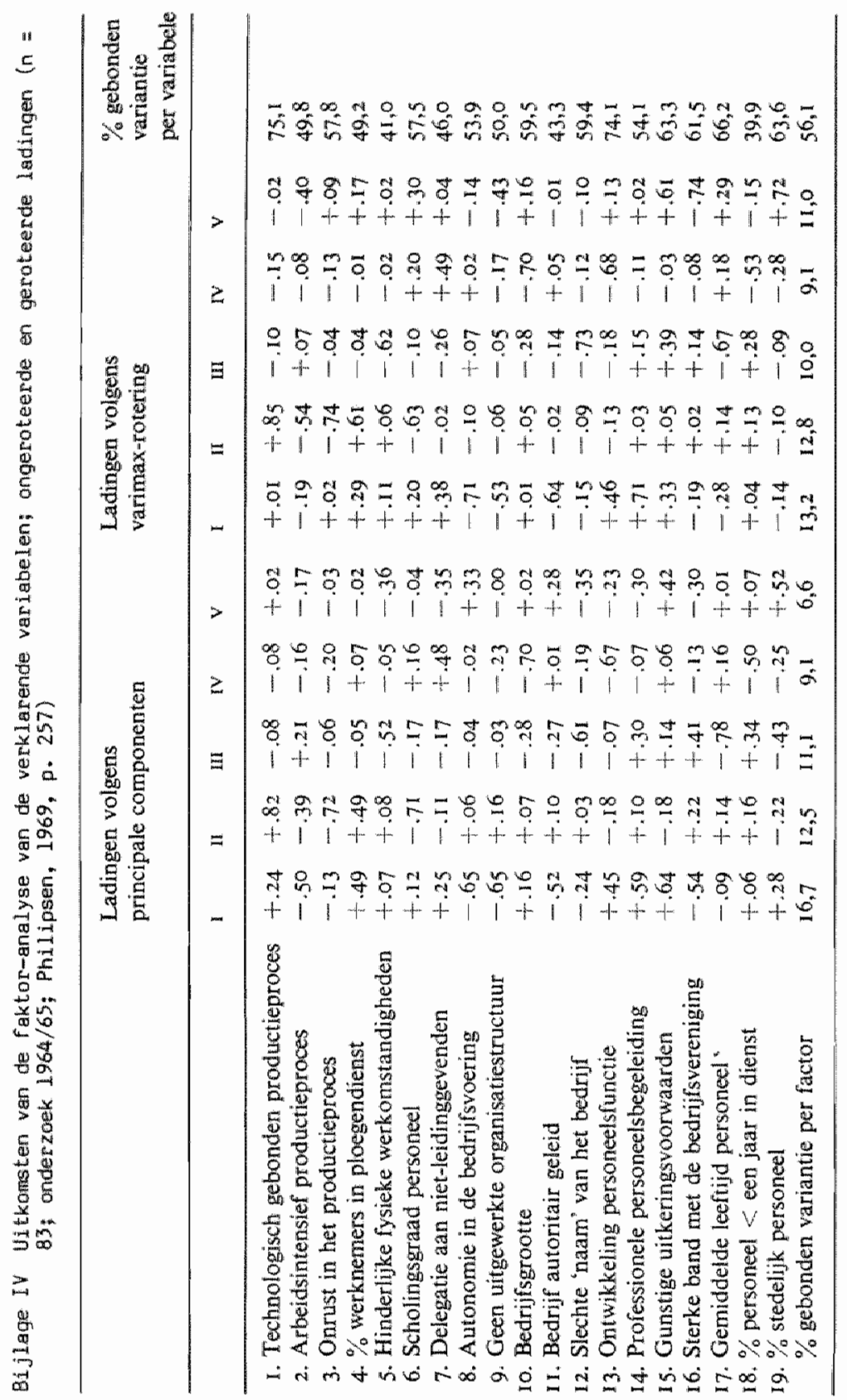


AANONSEN, A. Shift work and health. Oslo, Univ.Forlaget, 1964. ACTON SOCIETY TRUST, THE. Size and morale. Part 1. A preliminary study of attendance at work in large and small units. London, Acton Soc. Trust, 1953.

ACTON SOCIETY TRUST, THE. Size and morale. Part 2. A further study of attendance at work in large and small units. London, Acton Soc. Trust, 1957.

ADAMS, J.S. Inequity in social exchange. In: I. Berkowitz (ed.). Advances in experimental social psychology; vol 2. New York, Academic Press, 1965. Pp. 267-99.

ALEZRA, D., P. BOREL, C. FOURIAUD et al. Absentéisme chez les travailleurs africains. Arch.Mal.prof. 40 (1979) 329-30

ALGERA, J.A. Kenmerken van werk; de constructie van een instrument voor het meten van taakkenmerken, die van invloed zij jn op de motivatie, satisfactie, en prestaties van taakuitvoerenden. Meppel, Krips Repro, 1980. Proefschrift.

ALLEGRO, J.T. Socio-technische organisatieontwikkeling. Leiden, Stenfert Kroese, 1973.

ALLEN, S.G. Compensation, safety and absenteeism: evidence from the paper industry. Industr.Lab.Rel. Rev. 34 (1981) 207-18 ANGERSBACH, D., P. KNAUTH, H. LOSKANT et al. A retrospective cohort study comparing complaints and diseases in day and shift workers. Int.Arch.occup.environm.HIth 45 (1980) 12740

ANGLE, H.L., \& J.L. PERRY. An empirical assessment of organizational commitment and organizational effectiveness. Admin. Sci.Quart. 26 (1981) $1-14$

ARGYLE, M., G. GARDNER \& F. CIOFFI. Supervisory methods related to productivity, absenteelsm, and labour turnover. Hum.ReLat. 11 (1958) 23-40

AS, D. Absenteeism - a social fact in need of a theory. Acta sociol. 6 (1962) 278-85

BAHR, H.M., Th. CAPLOW \&.A. CHADWICK. Middletown III: Problems of replication, longitudinal measurement, and triangulation. Ann.Rev.Sociol. 9 (1983) 243-64

BAKER, C.C., \& S.J. POCOCK. Ethnic differences in certified sickness absence. Brit.J.industr.Med. 39 (1982) 277-82 
BARR, A. Absenteeism among hospital nursing staff. Hospital 63 (1967) $9-12$

BAUM, J.F., \& S.A. YOUNGBLOOD. Impact of an organizational control policy on absenteeism, performance, and satisfaction. J.appl.Psychol. 60 (1975) 688-94

BAUM, J.F. Effectivenese of an attendance control policy in reducing chronic absenteeism. Personnel Psychol. 31 (1978) $71-81$

BAUMGARTEL, H., \& R. SOBOL. Background and organizational factors in absenteeism. Personnel Psychol. 12 (1959) 431-43

BEEHR, T.A., N. GUPTA. A note on the structure of employee withdrawal. Organ. Beh.hum.Perf . 21 (1978) 73-9

BEHREND, $H$. Absence and labour turnover in a changing economic climate. Occup.Psycholl. 27 (1953) 69-79

BEINUM, H.J.J VAN, M.R. VAN GILS \& E.J. VERHAGEN. Taakontwerp en werkorganisatie; een sociotechnisch veldexperiment. London, Tavistock Inst.hum.Relat. / Leiden, NIPG-TNO, 1967.

BELT, A.B. Een poging tot verklaring van de ziektefrequentie en ziekteduur van buitenlandse werknemers bij een grote onderneming. T.soc.Geneesk. 56 (1978) 808-13

BERGH, H. VAN DEN, \& P. OUWEHAND. Conjunctuur en ziekteverzuim. Leiden, NIPG, 1965. (Scriptie in het kader van de basiscursus Soc.Geneesk. van het NIPG te Leiden).

BERNBERG, R.E. 5ocio-psychological factors in industrial morale: 1. The predictions of specific indicators. J.soc. Psychol. 36 (1952) 73-82

BEW5, D.C. A medical program to assist management in the control of absenteeism. J.occup.Med. 8 (1966) 243-50

BIRCHALL, D.W., \& R. WILD. Perceived job attributes, job attitudes and the behaviour of blue collar workers: a research note. J.Manag. Stud. 13 (1976) 191-5

BLAU, P.M., \& W.R. SCOTT. Formal organizations; a comparative approach. London, Routledge Kegan Paul, 1963.

BLAU, P.M., \& R.A. SCHDENHERR. The structure of organizations. New York, etc., Basilc Books, 1971.

BLAUNER, R. Alienation and freedom; the factory worker and his industry. Chicago, Londan, Univ.Chicago press, 1964.

BLUMBERG, M. Job switching in autonomous work groups: an exploretory study in a Pennsylvania coal mine. Acad.Manag.J. 23 (1980) 287-306 
BOER, L. DE. Resultaat afschaffing (routine-)ziektecontrole. T. soc.Geneesk. 42 (1964) 921-4

BOSEMAN, F.G., \& R.E. JONES. Market conditions, decentralization, and organization effectiveness. Hum. Relat. 27 (1974) 665-76

BRAGG, J.E., \& I.R. ANDREWS. Participative decision making: an experimental study in hospital. J.appl.behav.Sci. 9 (1973) $727-35$

BRAND-KOOLEN, M.J.M. Factoranalyse in het sociologisch onderzoek; explicatie en evaluatie van enige modellen. Leiden, Stenfert Kroese, 1972.

BREAUGH, J.A. Predicting absenteeism from prior absenteeism and work attitudes. J.appI.Psychol. 66 (1981) 555-60

BROEKE, J. TEN. Een eerste analyse van het ziekteverzuim naar aard en graotteklasse van de bedrijuen. Amsterdam, Econom. Inst. Bouwnijwerh., 1976.

BUITENDAM, A. Personeelafdelingen in de industrie; een empirisch onderzoek maar de structuur en het functioneren van personeelafdelingen in industriële ondernemingen in Nederland. Groningen, Konstapel, 1979.

BURNS, T., \& G.M. STALKER. The management of innovation. London, Tavistock, 1961.

CAILLARD, J.F., P. FRIMAT \& D. FURON. L" absentéisme; statistiques, méthodes de calcul. Arch.Mal.prof. 39 (1978) 271-7

CAMPBELL, J.P., M.D. DUNNETTE, E.E. LAWLER III \& K.E. WEICK Jr. Managerial behavior, performance, and effectiveness. New York, McGraw-Hill, 1970.

CASSEE, E.Th. Leiderschap en rolbegrenzing in een ziekenhuisorganisatie. Sociol.Gids 14 (1967) 86-100

CBS (CENTRAAL BUREAU VOOR DE STATISTIEK). Statistisch zakboek. Den Harg, Staatsuitgeverij, 1983.

CHADWICK-JONES, J.K., C.A. BROWN \& N. NICHOLSON. A-type and Btype absence: empirical trends for women employees. 0ccup. Psychol. 47 (1973) 75-80

CHADWICK-JONES, J.K., N. NICHOLSON \& C. BROWN. Soclal psychology of absenteeism. New York, Praeger, 1982.

CHELOHA, R.S., \&.L. FARR. Absenteeism, job involvement, and job satisfaction in an organizational setting. J.appl.Psychol. 65 (1980) $467-73$

CHEVROLLE, J. Comparaison de la fréquence et de la durée de l'absentéisme chez des ouvriers travaillant en horalre normal et en équipe $2 \times 8$. Arch.Mal.prof. 30 (1969) 348-5I. 
COLLIGAN, M.J., I.J. FROCKT \& D.L. TASTO. Frequency of sickness absence and worksite clinic visits among nurses as a function of shift. Appl. Ergonom. 10 (1979) 79-85

COLLINS, C.P. Sickness absence in three principal ethnic divisions of Singapore. Brit.J.industr.Med. 19 (1962) 116-22

COOPER, R. Leader's task relevance and subordinate behaviour in industrial work groups. Hum. Relat. 19 (1966) 57-84

CROWTHER, J. Absence and turnover in the divisions of one company (1950-1955). dccup.Psychol. 31 (1957) 256-69

CUMMINGS, Th.G., \& W.H. GRIGGS. Worker reactions to autonomous work groups: conditions for functioning, differential effects, and individual differences. Organ.admin.Sci. 7 $(1976 / 77) 87-100$

DALTON, D.R., \& J.L. PERRY. Absenteeism and the collective bargaining agreement; an empirical test. Acad.Manag.J. 24 (1981) 425-31

DITTRICH, J.E., \& M.R. CARRELL. Organizational equity perceptions, employee job satisfaction, and departmental absence and turnover rates. Organ.Behav.hum.Perf. 24 (1979) 29-40

DOHERTY, N.A. National insurance and absence from work. Econom.J. 89 (1979) 50-65

DRAAISMA, D. Ziekteverzuim, WAD-intrede en verzekeringsvorm in de Ziektewet. Den Haag, Min.Soc.Z.Werkgelegenh., 1983.

DIJKHUIZEN, N. VAN. From stressors to strains; research into their interrelationships. Lisse, Swets \& Zeitlinger, 1980.

DIJKSTRA, A. Inkrimping van het personeelbestand in produktiebedrijven en afwezigheid wegens ziekte; een longitudinale sekundaire analyse. Sociol.Gids 21 (1974) 3-15

DIJKSTRA. A. Determinanten van ziekteverzuim in produktieorganisaties voor gehandicapten. Leiden, NIPG-TNO, 1977. Proefschrift.

EDWARDS, P.K. Attachment to work and absence behavior. Hum. Relat. 32 (1979日) 1065-80

EDWARDS, P.K. Strikes and unorganised conflict: some further considerations. Brit.J.industr.Relat. 17 (1979b) 95-8

EKKER, W. Ziekteverzuim als bedrijfskenmerk. Mens \& Ondern. 20 (1966) $1-12$

EKKERS, C.L., A.A.F. BRDUWERS, C.K. PASMOOY \& P.M. DE VLAMING. Menselijke stuur- en regeltaken. Leiden, NIPG-TNO, 1980. 
ENGELSDORP GASTELAARS, R.E. VAN, W.J.M. OSTENDORF \& S. DE VOS. Typologieën van nederlandse gemeenten naar stedelijksheidsgraad. Den Haag, Staatsuitgeverij, 1980. (CBS/SISWO. Monogr.volkst. 1971, nr. 15B).

ENTERLINE, Ph.E. Arbeidsverzuim door ziekte in een aantal Westerse landen. Mens \& Ondern. 18 (1964) 162-72

ERP, Th. VAN. De geneeskundige behandeling van Spaanse arbeiders in Nederland. Ned.T.Geneesk. 111 (1967) 1912-6

FENN, P. Sickness duration, residual disability and income replacement: an empirical analysis. Econom.J. 91 (1981) 15873

FESTINGER, L. A theory of cognitive dissonance. Stanford, Stanford univ.press, 1957.

FIREBAUGH, G. A rule for inferring individual-level relationships from aggregate data. Amer.sociol.Rev. 43 (1978) 557-72

FITZGIBBONS, D., \& M. MDCH. Employee absenteelsm: a multivariate analysis with replication. 0rgan.Beh.hum.Perf. 26 (1980) $349-72$

FLEISHMAN, E.A., E.F. HARRIS \& H.E. BURTT. Leadership and supervision in industry; an evaluation of a supervisory training program. Ohio, Bur.Educ.Res. / Ohio State Univ., 1955.

FORD, J.D. Institutional versus questionnaire measures of organizational structure: a reexamination. Acad.Manag.J. 22 (1979) 601-10

FORD, R.N., \& M.B. GILLETTE. Studies in AT \& T's treasury department. Part A. A new approsch to job motivation; improving the work itself. Part B. Permanency of results; treasury revisited 18 months later. In: R.N. Ford. Motivation through the work itself. New York, Amer.Manag.Ass., 1969. Chpt. 2, pp. 20-44.

FORTUIN, G.J. Sickness absenteeism. Bull.Wld.Hlth Org. 13 (1955) $513-41$

FRIED, J., M. WEITMAN \& M.K. DAVIS. Man-machine interaction and absenteeism. J.appl.Psychol. 56 (1972) 428-9

FRY, L.W. Technology-structure research: three critical issues. Acad.Manag.J. 25 (1982) 532-52

GADOUREK, I. Absences and well-being of workers. Assen, Van Gorcum, 1965.

GADOUREK, I. Boekbespreking van: H. Philipsen. Afwezigheid wegens ziekte, Groningen, Wolters-Moordhoff, 1969. Mens \& Ondern. 24 (1970) 209-12 
GALTUNG, J. Theory and methods of social research. Oslo, Universitetsforlaget, 1967. (Monogr. $\mathrm{nr} .1$ ).

GATER, A., D. INSULL, H. LIND \& P. SEGLOW. Attitudes in British management; a P.E.P. report. Middlesex, Penguin books, 1966.

GERSTENFELD, A. Employee absenteeism: new insights; data reveal external factors. Business Horizons 12 (1969) $51-7$

GERWIN, D. Relationships between structure and technology. In: P.C. Nystram \& W.H. Starbuck (eds). Handbook of organizational design; vol. 2. Oxford, Dxford univ.press, 1981. Chpt. 1, pp. 3-38.

GIBSON, R.0. Toward a conceptualization of absence behavior of personnel in organizations. Admin.5ci.Quart. 2 (1966) 10733

GORDON, R.A. Issues in multiple regression. Amer.J.5ociol. 73 (1968) 592-616

GROOT, A.D. DE. Methodologie; grondslagen van onderzoek en denken in de gedragswetenschappen. Den Haag, Mouton, 1961.

GROOT, J. DE. Over ziekencontrole en ziekteverzuim. T.soc.Geneesk. 48 (1970) 2-1.2; 19

GROOT, M.J.W. DE. Controlegewoonten en ziekteverzuim. Mens \& Ondern. 8 (1954) 332-48

GROOT, M.J.W. DE. Veranderingen in verzuimfrequenties in het algemeen en door "neurosen" in het bijzonder. In: M.J.W. de Groot. Kwantitatieve benadering van het verzuim door neurosen bij Nederlandse fabrieksarbeiders. Leiden, NIPG-TNO, 1958. Hfst. 9, pp. 111-20

GUEST, R.M. Managerial succession in complex organizations. Amer. J.5ociol. 68 (1962) 47-56

GUPTA, N., \& T.A. BEEHR. Job stress and employee behaviors. Organ. Beh.hum.Perf. 23 (1979) 373-87

HACKMAN, J.R., \& E.E. LAWLER. Employee reactions to job characteristics. J.appl.Psychol. Monogr. 55 (1971) 259-86

HACKMAN, J.R., \& G.R. OLDHAM. Motivation through the design of work: test of a theory. Organ. Beh.hum.Perf. 16 (1976) 25079

HACKMAN, J.R., J.L. PEARCE \& J.C. WOLFE. Effects of changes in job characteristics on work attitudes and behaviors: a naturally occurring quasi-experiment. Organ.Beh.hum.Perf. 2.1. (1978) 289-304 
HALL, R.D. Organizations: structure and process; 3rd ed. Englewood Cliffs, N.J., Prentice-Hall, 1982.

HAMMER, T.H., \& J. LANDAU. Methodologícal issues in the use of absence data. J.appl.Psychol. 66 (1981) 574-81

HAMMER, T.H., J.C. LANDAU \& R.N. STERN. Absenteeism when workers have a voice: the case of employee ownership. J.appl.Psychol. 66 (1981) 561-73

HANDY, L.J. Absenteeism and attendance in the Britisch coalmining industry: an examination of past-war trends. Brit.J. industr. Relat. 6 (1968) 27-50

HANNAN, M.T., \& L. BURSTEIN. Estimation from grouped observations. Amer.sociol.Rev. 39 (1.974) 374-92

HEDGES, J. Absence from work - a look at some national data. Mth. Lab.Rev. 96 (1973) nr. 7, 24-30

HERSHEY, R. Effects of anticipated job loss on employee behavior. J.appl.Psychol. 56 (1972) 273-5

HERTOG, J.F. DEN, \& H.P. VOSSEN. Speciale miniatuur Terneuzen; evaluatie wan de technische en sociale doelstelling van een werkstruktureringsexperiment. Eindhoven, Philips, 1974.

HICKSON, D.J., D.S. PUGH \& D.C. PHEYSEY. Operations technology and organization structure: an empirical reappraisal. Admin.Sci.Quart. 14 (1969) 378-97

HILL, J.M.M., \& E.L. TRIST. A consideration of industrial accidents as a means of withdrawal from the work situation. Hum. Relat. 6 (1953) 357-80

HOLTHUIS, R. De betekenis van de krachtens de Ziektewet uitgeoefende geneeskundige controle. Enschede, Van der Loeff, 1961. Proefschrift.

HOOLWERF, G., H. THIERRY \& P.J.D. DRENTH. Ploegenarbeid; een bedrijfspsychologisch onderzoek. Amsterdem, VU, 1974.

HOLBEN, G.J. Produktiestress; de gevolgen van spanningen tussen eisen, hulpbronnen en waardering in het industriële produktieproces. Utrecht, RU, 1981. Proefschrift.

HOUSE, R.J., \& M.L. BAETZ. Leadership: some empírical generalizations and new research directions. In: B.M. Staw (ed.). Research in organizational behavior; vol. 1. Greenwich, Conn., JAI press, 1979. Pp. 341-423.

ILGEN, D.R., \& J.H. HOLLENBACK. The role of job satisfaction in absence behavior. Organ.Beh.hum.Perf. 19 (1977) 148-61 
INOIK, B.P. Organization size and member participation; some empirical tests of alternative explanations. Hum. Relat.18 (1965) $339-50$

INGHAM, G. Size of industrial organization and worker behavior. Cambridge, Cambridge univ.press, 1970.

ISAMBERT-JAMATI, $W$. Absenteelsm among women workers in industry. Int.Lab.Rev. 85 (1962) 248-61

JAMAL, M. Shift work related to job attitudes, social participation and withdrawal behavior: a study of nurses and industrial workers. Personnel Psychol. 34 (1981) 535-47

JARDILLIER, $P$. Étude de 14 facteurs influant sur l'absentéisme industriel. Trav.hum. 25 (1962) 107-16

JOHNS, G. Attitudinal and nonattitudinal predictors of two forms of absence from work. Organ.Beh.hum.Perf. 22 (1978) 431-44

JOHNS, G., \&. NICHOLSON. The meaning of absence: new strategies for theory and research. In: B.M. Staw \& L.L. Cummings (eds). Research in organizational behavior; vol. 4. Greenwich, Conn., JAI press, 1982. Pp. 127-72.

JONG, P.H. DE, H. BRUINSMA, L. AARTS \& J.P. HOP. Determinantenonderzoek WAO, fase 1 : determinanten van WAO-toetreding; een eerste totaalbeeld. Den Haag, Soc. Verzekeringsr., 1981. JÜRESKOG, K.G., \& D. SÖRBOM. LISREL IV. Chicago, Nat.educ.Resources, 1978.

KALLEBERG, A.L., \& A.B. SØRENSEN. The sociology of labor markets. Ann.Rev.Sociol. 5 (1979) 351-79

KARASEK, R.A. Job demands, job decision latitude, and mental strain: implications for job redesign. Admin.Sci.Quart. 24 (1979) 285-308

KERN, H. , \& M. SCHUMANN. Industriearbeit und Arbeiterbewusstsein; eine empirische Untersuchung über den Einfluss der aktuellen technischen Entwicklung auf die industrielle Arbeit und das Arbeiterbewusstsein. 2 Tln. Frankfurt am Main, Köln, Europäische Verlagsanst., 1970.

KHANDWALLA, P.N. Properties of competing organizations. in: P.C. Nystrom \& W.H. Starbuck (eds.). Handbook of organizational. design; val. 1. Oxford, 0xford univ.press 1981. Chpt. 18, pp. 409-32.

KILBRIDGE, M.D. Turnover, absence and transfer rates as indicators of employee dissatisfaction with repetitive work. Industr.Lab.Relat.Rev.15 (1961) 21-32 
KNOX, J.B. Absenteeism and turnover in an Argentine factory. Amer.sociol.Rev. 26 (1961) 424-8

KOOT, W.T.M. Analyse van organisatiestructuren; de geldigheid en bruikbaarheid van de Aston-studies. Alphen a.d. Rijn etc., Semsom, 1981.

KOVACH, K.A. Organization size, job satisfaction, absenteeism and turnover. Washington, University Press of America, 1978.

KRUIDENIER, H.J. Ziekteverzuim 1977-1980; enkele cijfers uit het registratiesysteem van de Stichting $\mathbb{C} C O Z$. Amsterdam, Stichting $\mathrm{CCOZ}, 1982$.

LAMMERS, C.J. Uiterlijke samenhang en bindingskracht van de organisatie. Assen, Van Gorcum, 1964. (Rede uitgesproken bij de aanvaarding van het ambt van gewoon hoogleraar in de sociologie van de organisatie an de Rijksuniversiteit te Leiden op vrijdag 9 oktober 1964 ).

LAMMERS, C.J. Sociale oorzaken van het ziekteverzuim. Soc.Maandbl.Arbeid 21 (1966) 480-94

LAMMERS, C.J. Organisaties vergelijkenderwijs; ontwikkeling en relevantie van het sociologische denken over organisaties. Utrecht etc., Spectrum, 1983.

LAWLER, E.E., J.R. HACKMAN. Impact of employee participation in the development of pay incentive plans: a field experiment. J. appl.Psychol. 53 (1.969) 467-71

LAWLER, E.E., J.R. HACKMAN \& S. KAUFMAN. Effects of job redesign: a field experiment. J.appl.soc.Psychol. 3 (1973) 49-62

LEGGE, K., \& S. HILLING. Absence, overtime and the structure of the pay packet: some methodological points. Part 1 . J. Manag.Stud. 11 (1974) 205-23

LIDDELL, F.D.K. Attendance in the coal-mining industry. Brit.J. Sociol. 5 (1954) 73-86

LIKERT, R. New patterns of management. New York etc. McGrawHill, 1961.

LUNDQUIST, A. Absenteeism and job turnover as a consequence of unfavorable job adjustment. Acta sociol. 3 (1958) 119-31

MANN, K.J., J.H. ABRAMSON, I. CAMRASS \& J. ALON. Sickness absenteeism in a hospital in Israel. Hospital 67 (1971) 307-11 MARCH, J.G., \& H.A. SIMON. Organizations. Mew York, Wiley, 1958. MARKHAM, S.E., F. DANSEREAU \& J.A. ALUTTO. Female vs. male absence rates: a temporal analysis. Personnel Psychol. 35 (1982a) $371-82$ 
MARKHAM, S.E., F. DANSEREAU \& J.A. ALUTTO. Group size and absentee $\operatorname{sm}$ rates: a longitudinal analysis. Acad.Manag.J. 25 $\left(1982^{b}\right) 921-7$

MELBIN, M. Organization practice and individual behavior absenteeism among psychiatric aides. Amer.sociol.Rev. 26 (1961) $14-23$

METZNER, H., \& F. MANN. Employee attitudes and absences. Personnel Psychol. 6 (1953) 467-85

MINER, M.G. Job absence and turnover: a new source of data. Mth. Leb.Rev. 100 (1977) nr. 10, 24-31

MIRVIS, Ph.H., \& E.E. LAWLER III. Measuring the financial impact of employee attitudes. J.appl. Psychol. 62 (1977) 1-8

MORGAN, L.G., \& J.B. HERMAN. Perceived consequences of absenteeism. J.appl.Psychol. 51 (1976) 738-42

MOTOWIDL0, St. J., W.C. BORMAN. Relationship between military morale, motivation, satisfaction, and unit effectiveness. J.eppl.Psychol. 63 (1978) 47-52

NEGANDHI, A.R., \& B.C. REIMANN. Task enviromment, decentralization and organizational effectiveness. Hum.Relat. 26 (1973) $203-1.4$

NICHOLSON, N. Management sanctions and absence control. Hum. Relat. 29 (1976) 139-51

NICHOLSON, N., C.A. BROWN \& J.K. CHADWICK-JONES. Absence from work and job satisfaction. J.appl.Psychol. 61 (1976) 728-37

NICHOLSON, N. Absence behaviour and attendance motivation: a conceptual synthesis. J.Manag.Stud. 14 (1977) 231-52

NICHOLSON, N., C.A. BROWN \& J.K. CHADWICK-JONES. Absence from work and personel characteristics. J.appl.Psychol. 62 $\left(1977^{\circ}\right), 319-27$

NICHOLSON, N., T. WALL, \& J. LISCHERON. The predictability of absence and propensity to leave from emplayees' job satisfaction and attitudes toward influence in decision-making. Hum. Re 1日t. 30 (1.977b) $499-514$

NIJHUIS, F. \& J. SUETERS. Werk en ziekte; een onderzoek naar afwerigheid wegens ziekte en arbeidsongeschiktheid bij 51 industriële en niet-industriële organisaties in $Z$-Limburg. Maastricht, RU Limburg, 1982.

OLDHAM, M., \& R. WILD. Job and role dissonance and withdrawal from work among women workers. Personnel Rev. 8 (1979) winter, $24-30$ 
O'MUIRCHEARTAIGH, C.A. Absenteeism in Irish industry. Dublin, Irish Prod.Centre; Hum.Sci. Industry, 1975. (Study nr. 12). DRPEN, Ch. The effects of job enrichment on employee satisfaction, motivation, involvement, and performance: a field experiment. Hum. Relat. 32 (1979) 189-217

OWENS, A.C. Sick leave among railwaymen threatened by redundancy: a pilot study. Occup.Psychol. 40 (1966) 43-52

PASCALE, R.T., \& M.A. MAGUIRE. Comparison of selected work factors in Japan and the United States. Hum.Relat. 33 (1980) 433-55

PATCHEN, M. Absence and employee feelings about fair treatment. Personnel Psychol. 13 (1960) 349-60

PATCHEN, M. Some questionnaire measures of employee motivation and morale; a report on their reliability and validity. Ann Arbor, Mich., Inst.soc.Res. / Univ.Michigan, 1965. (Monogr. 41).

PATCHEN, M. Participation, achievement, and involvement on the job. Englewood Cliffs, N.J., Prentice-Hall, 1970.

PAYNE, R., \& D.5. PUGH. Organizational structure and climate. In: M.R. Dunnette (ed.). Handbook of industrial and organizational psychology. Chicago, Rand MoNally, 1976. Chpt. 26, pp. $1125-73$.

PEDHAZUR, E.J. Multiple regression in behavioral research; explanation and prediction; 2nd ed. New York etc., Holt, Rinehart \& Winston, 1982.

PEETERS, R.F., M. VAN SPRUNDEL \& A.Z. MEHEUS. Ziektegedrag bij migranten; afwezigheid op het werk wegens ziekte bij Marokkanen; een vergelijkende studie. T.soc.Geneesk. 60 (1982) $278-81$

PENNINGS, J. Measures of organizational structure: a methodological note. Amer.J. Sociol. 79 (1.973) 686-704

PENNINGS, J.M. Dimensions of organizational influence and their effectiveness correlates. Admin.Sci.Quart. 21 (1976) 688-99 PENNINGS, J.M., \& R.C. TRIPATHI. The organization - environment relationship: dimensional versus typological viewpoints. In: L. Karpik (ed.). Organization and environment; theory, issues and reality. London, Sage pub1. 1978. Pp. 171-95.

PERROW, Ch. A framework for the comparative analysis of organizations. Amer.sociol. Rev. 32 (1967) 194-208 
PFEFFER, J., \&. LEBLEBICI. The effect of competition on some dimensions of organizational structure. Social Forces 52 (1973) 268-79

PHILIPSEN, H. Het meten van leiderschap. Mens \& Ondern. 19 (1965) 153-71

PHILIPSEN, H. Enkele aspecten van het stijgend ziekteverzuim. 2. De beslissing om ziek te morden en veranderde opvattingen over de verzuimnoodzaak. Mens \& Ondern. 20 (1966 $\left.{ }^{\mathrm{a}}\right) 280-$ 91

PHILIPSEN, H. Enkele aspecten van het stijgend ziekteverzuim. 3. De verzuimgelegenheid, 'eigen risico' en het verzuimpatroon. Mens \& Dndern. 20 (1966b) 342-52

PHILIPSEN, $H$. Afwezigheid wegens ziekte. Groningen, WoltersNoordhoff, 1969. Proefschrift.

PHILIPSEN, H. De voorwaardelijkheid van algemene uitspraken toegelicht aan de samenhang tussen werkvoldoening en afwezigheid wegens ziekte. Sociol.Gids 17 (1970) 320-32

PHILIPSEN, H. Levensfase, generatie en ziekteverzuim; de invloed van belastende levensomstandigheden, mentaliteit en riskante gewoonten op het aantal ziekmeldingen. Masstricht/Leiden, RUL/NIPG-TNO, 1977.

PLANTENGA, J. De keuze van het signifikantieniveau bij beleidsvoorbereidend sociaal-wetenschappelijk onderzoek. Sociol. Gids 28 (1981) 69-79

PLLIMMER, N., \& L.E. HINKLE. Sickness absenteeism. Arch.industr. HIth A.M.A. 11 (1955) 218-30

POWELL, R.M., \& J.L..SCHLACTER. Participative management, a panacea? Acad.Manag. J. 14 (1971) 165-73

PUGH, D.S., C. GORDON \& K. LEVY. Sickness absence among railway clerical staff. Brit.J.industr.Med. 16 (1959) 269-73

PUGH, D.5., D.J. HICKSON, C.R. HININGS \& C. TURNER. Dimensions of organization structure. Admin. Sci.Quart. 13 (1968) 65-105

PUGH, D.S., D.J. HICKSON, C.R. HININGS \& C. TURNER. The context of organization structures. Admin.Sci.Quart. 14 (1969) 91114

REICHE, H.M.J.K.I., \& N. VAN DIJKHUIZEN. Bedrijfsgrootte, hiërarchie en persoonlijkheld: beïnvloeden zij het ervaren van stressoren en strains? Gedrag 7 (1979) 58-75

REVANS, R.W. Human relations, management and size. In: E.M. HughJones (ed.). Human relations and modern management. Amsterdam, North-Holland pub1.Comp. 1958. Chpt. 7, pp. 177-220. 
REVANS, R.W. Standards for morale; cause and effect in hospitals. London, Oxford univ.press, 1964.

RHODES, S.R., \& R.M. STEERS. Conventional vs. worker-owned organizations. Hum.Relat. 34 (1981) 1013-35

RIS, B.G.M. Personeelsbeleid en ziekteduur; verslag van een onderzoek bij 39 bedrijuen. Leiden, NIPG-TNO, 1978.

ROBERTS, K.H., C.L. HULIN \& D.M. ROUSSEAU. Developing an interdisciplinary science of organizations. San Francisco, Jossey-Bass, 1978.

RONAN, W.W., G.P. LATHAM \& S.B. KINNE. Effects of goal settings and supervision on worker behavior in an industrial situation. J.appl.Psychol. 58 (1973) 302-7

ROUSSEAU, D.M. Characteristics of departments, positions and individuals: contexts for attitudes and behavior. Admin.Sci. Quart. 23 (1978) 521-40

RUSHMORE, C.H., \& S.A. YOUNGBLOOD. Medically-related absenteeism; random or motivated behavior? J.occup.Med. 21 (1979) 245-50

SAAL, F.E. Job-involvement: a multivariate approach. J.appl.Psychol. 63 (1978) 53-61

SATHE, V. Institutional versus questionnaire measures of organizational structure. Acad.Manag.J. 21 (1978) 227-38

SCHMIDT, W. Psychologische Aspekte der krankheitsbedingten Fehlzeiten im Betrieb; empirische Untersuchungen unter besonderer Berücksichtigung sozialpsychologischer Faktoren. BerIin, Beuth-Vertrieb GmbH, 1967. Proefschrift.

SCHMIDT-BRASSE, U., \& 0. NEUBERGER. Vorgesetztenverhalten, Zufriedenheit und Absentismus. Z.exp.angew.Psychol. 20 (1973) $663-83$

SCHMOLL, H.J. Zum Krankenstand der ausländischen Arbeitsnehmer. Münch.med.Wschr. 1.15 (1973) 2280-4

SCHOKKING-SIEGERIST, E.C. Ziekteverzuim van wrouwelijke werknemers. D1. 1. Statistische analyse van verzuimregistratiegegevens. D1. 2. Een inventarisatie van faktoren die samenhangen met de matschappelijke positie van werkende vrouwen en die van belang kumnen zijn voor hun ziekteverzuim. Dl. 3. Opzet en uitkomsten van het surveyonderzoek naar ziekteverzuim van vrouwelijke werknemers. Leiden, NIPG-TNO, 1979. SHEPHERD, R.D., \& J. WALKER. Three-shift working and the distribution of absence. Occup.Psychol. 30 (1956) 105-11 
SIEGEL, A.L., \&.A. RUH. Job involvement, participation in decision making, personal background and job behavior. Organ. Beh.hum.Perf. 9 (1973) 318-27

SINGHAL, 5. Need-gratification, absenteeism and its other correlates. Indian J.industr. Relat. 2 (1976) 351-61

SINHA, D. Personal factors in absenteeism. Indian J.soc. Work 17 (1956) $86-93$

SITTER, L.U. DE. Op weg naar nieuwe fabrieken en kantoren; produktie-organisatie en arbeidsorganisatie op de tweesprong. Deventer, Kluwer, 1981.

SMITH, D. Control and orientations to work in a business organization. J.Manag.Stud. 15 (1978) 211-22

SMITH, F.J. Work attitudes as predictors of attendance on a specific day. J.appl.Psychol. 62 (1977) 16-9

SMULDERS, P.G.W. Comments on emplayee absence/attendance as a dependent variable in arganizational research. J.appl.Psychol. 65 (1980) 368-71

SMULDERS, P.G.W. Onderzoek en aanpak van het verzuim in een groot Nederlands metaalbedrijf.

Veranderingskundige conclusies rond verzuim uit ervaringen bij een groot metaalbedrijf.

In: V.Ch. Vrooland (red.). Werk en gezondheid; over ziekteverzuim en humanisering van de arbeid. Alphen a.d. Rijn, Sansom, 1982. Hfst. 14-15, pp. 188-98, 199-210.

SMLLDERS, P.G.W. Personal, nonwork and work characteristics in male and female absence behavior. J.occup.Beh. 4 (1983) 285-95

SMULDERS, P.G.W., P. VAN LEEUWEN \& W.N. VAN NOOTEN. Werkloosheid en zlekteverzuim: theorie en longitudinaal onderzoek. Gezondh.\& Samen1. 4 (1983a) 23-31

SMULDERS, P.G.W., A. DIJKSTRA, P. VAN LEEUWEN \& D. DRAAISMA. Enige achtergronden van het dalend ziekteverzuim in Nederland; resultaten van een sekundaire analyse van de NIPG/TND-ziekteverzuimstatistiek. Den Haag, Min.Soc.Z.Werkgelegenh., $1983^{\mathrm{b}}$.

SMULDERS, P.G.W. Balans van 30 jaar ziekteverzuimonderzoek; de resultaten van 318 studies samengevat. Leiden, NIPG-TNO, 1984.

SPENCER, D.G., \& R.M. STEERS. The influence of personal factors and perceived work experiences on employee turnover and absenteeism. Acad.Manag.J. 23 (1980) 567-72 
STEERS, R.M. Antecedents and outcomes of organizational commitment. Admin.Sci.Quart. 22 (1977) 46-56

STEERS, R.M. \& S.R. RHODES. Major influences on employee attendance: a process model. J.appl.Psychol. 63 (1978) 391-407

STOGDILL, R.M., \& C.L. SHARTLE. Methods in the study of administrative leadership. Columbus, Ohio, Bur.Business Res. / Ohio State univ., 1955. (Research Monogr. 80).

STOGOILL, R.M., \& A.E. COONS (eds). Leader behavior: its description and measurement. Columbus, Ohio, Bur.Business Res. / Ohio State univ., 1957. (Research Monogr. 88).

STUDENT, K.R. Supervisory influence and work-group performance. J.appl.Psychol. 52 (1968) 188-94

SUMSION, L. A survey of absence rates in Australia. Personnel Pract.Bull. 30 (1974) 47-60

SZILAGYI, A.D. Causal inferences between leader reward behavior and subordinate performance, absenteeism and work satisfaction. J.occup.Psychol. 53 (1980) 195-204

TAN, K.H. Het ziekteverzuim in de ploegendienst. Leiden, 1967.

(Ongepubliceerde scriptie in het kader van de cursus bedrijfsgeneeskunde van het NIPG-TNO).

TANNENBAUM, A.5. Control in organizations. New York etc., McGrawHill, 1968.

TANNENBAUM, A.S., \& R.A. COOKE. Organizational control: a review of studies employing the control graph method. In: C.J. Lammers \& D.J. Hickson (eds). Organizations alike and unlike. London etc., Routledge Kegan Paul, 1979. Chpt. 11, pp. $183-210$.

TAYLOR, P.J. Shift and day work; a comparison of sickness absence, lateness, and other absence behavior at an oil refinery from 1962 to 1965. Brit.J.industr.Med. 24 (1967) 93102

TAYLOR, P.J. Self-certification for brief spells of sickness absence. Brit.med.J. 1 (1969) 144-7

TAYLOR, P.J., \& S.J. POCOCK. Post-war trends in sickness absence and unemployment in Great Britain. Lancet 2 (1969) 1120-3

TAYLOR, P.J., S.J. POCOCK \& R. SERGEAN. Absenteeism of shift and day workers; a study of six types of shift systems in 29 organizations. Brit.J.industr. Med. 29 (1972) 208-13 
TERBORG, J.R., T.W. LEE \& F.J. SMITH et al. Extension of the Schmidt and Hunter validity generalization procedure to the prediction of absenteeism behavior from knowledge of job satisfaction and organizational commitment. J.appl.Psychol. 67 (1982) 440-9

THIIS-EVENSEN, E. Skiftarbeid og helse; en undersokelse over helseproblemer ved rundskiftarbeid. Heöya, Norsk Hydro Eidanger Salpeterfabriker, 1958.

THOMAS, R.B. Wages, sickness benefits and absenteeism. J.econom. 5tud. 7 (1981) 51-61

TORDOIR, W.F., M.M. VAN DER KLAAUW \& C.M.J. VAN MANEN-BOEKESTEIN. Gezondheidszorg en langdurig arbeidsverzuim; ontwerp en uitvoering van een inventariserend onderzoek naar in de gezondheidszorg voorkomende verzuimduur-verlengende factoren van organisatorische aard. T.soc.Geneesk. 54 (1976) 249-60

TRIST, E.L., G.W. HIGGIN, H. MURRAY \& A.B. POLLOCK. Organizational cholice; capabilities of groups at the coal face under changing technologies. London, Tavistock Publ., 1963.

TLURNER, A.N., \& P.R. LAWRENCE. Industrial jobs and the worker; an investigation of response to task attibutes. Boston, Harvard unive, 1965.

VERTIN, P.G. Het ziekteverzuimpatroon van de buitenlandse werknemers. T.soc. Geneesk. 45 (1967) 486-92

VLIERT, E. VAN DE. Rolgedrag in de organisatie. Deventer, Kluwer, 1974.

VREDENBURGH, D.J., \& J.A. ALUTTO. Perceived structure in relation to individual attitudes and performance. Organ.admin.Sci. 8 (1.977) $255-72$

VR00M, V. Job satisfaction and job behavior. In: V. Vroom. Work and motivation. New York, Willey, 1964. Chpt. 6, pp. 175-87.

WADE, L. A 'human relations' approach to sickness absenteeism and other employee problems. Arch.industr.Hlth 12 (1955) 592608

WALL, T.D., C.W. CLEGG \& P.R. JACKSON. An evaluation of the job characteristics model. J.occup.Psychol. 51 (1978) 183-96

WALTON, E.J. The comparison of measures of organizations structure. Acad.Manag. Rev. 6 (1981) 155-60

WATSON, C.J. An evaluation of some aspects of the Steers and Rhodes model of employee attendance. J.appl.Psychol. 66 (1981) $385-9$ 
WEISS, E.C. Relation of personnel statistics to organizational structure. Personnel Psychol. 10 (1957) 27-42

WEXLEY, K.N., \& W.F. NEMEROFF. Effectiveness of positive reinforcement and goal setting as methods of management development. J.appl.Psychol. 60 (1975) 446-50

WIERSMA, D. Psychosociale 'stress' en langdurige arbeidsongeschiktheid. Groningen, Konstapel, 1979. Proefschrift.

WINKLER, D.R. The effects of sick-leave policy on teacher absenteeism. Industr.Lab.Relat.Rev. 33 (1980) 232-40

wooD, D.A. Effect of worker orientation differences on job attitude correlates. J.appl.Psychol. 59 (1974) 54-60

WOODWARD, J. Management and technology. London, MMSO, 1958.

WDODWARD, J. Industrial organization: theory and practice. London, Dxford univ. press, 1965.

WYATT, S., \& R. MARRIOTT. Night work and shift changes. Brit.J. industr.med. 10 (1953) 164-72 
De auteur van dit proefschrift werd in 1939 geboren te Utrecht. $\mathrm{Na}$ het behalen van het HBS-B diploma aan de Cemeentelijke HBS te Utrecht en de militaire dienst, volgde hij de studie sociologie in Utrecht, met als bijvak organisatie-sociologie te Leiden (doctoraal examen in 1967).

Hij was vervolgens in dienst van de Direktie Technische Hulp van het Ministerie van Buitenlandse Zaken en van de Verenigde Naties in Caracas/Venezuela.

Sinds 1974 is hij werkzaam bij het NIPG/TNO te Leiden. Als uitvloeisel van het zogenaamde Aktieprogramma Zlekteverzuim dat dit instituut in samenwerking met de SER uitvoerde, was hij co-auteur van het boek Ziekteverzuim en het Bedrijf (Leiden, Stenfert Kroese, 1978).

Hij publiceerde verder onder andere in Nederlandse en Amerikaanse tijdschriften op het gebied van arbeid en bedrijf, ziekteverzuim en bedrijfsgezondheidszorg. 